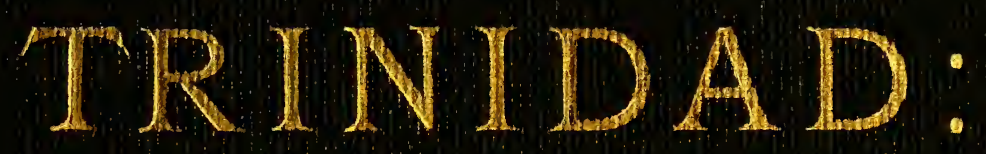

\title{
THEN AND NOW.
}

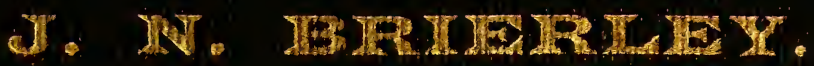

Price 01= 


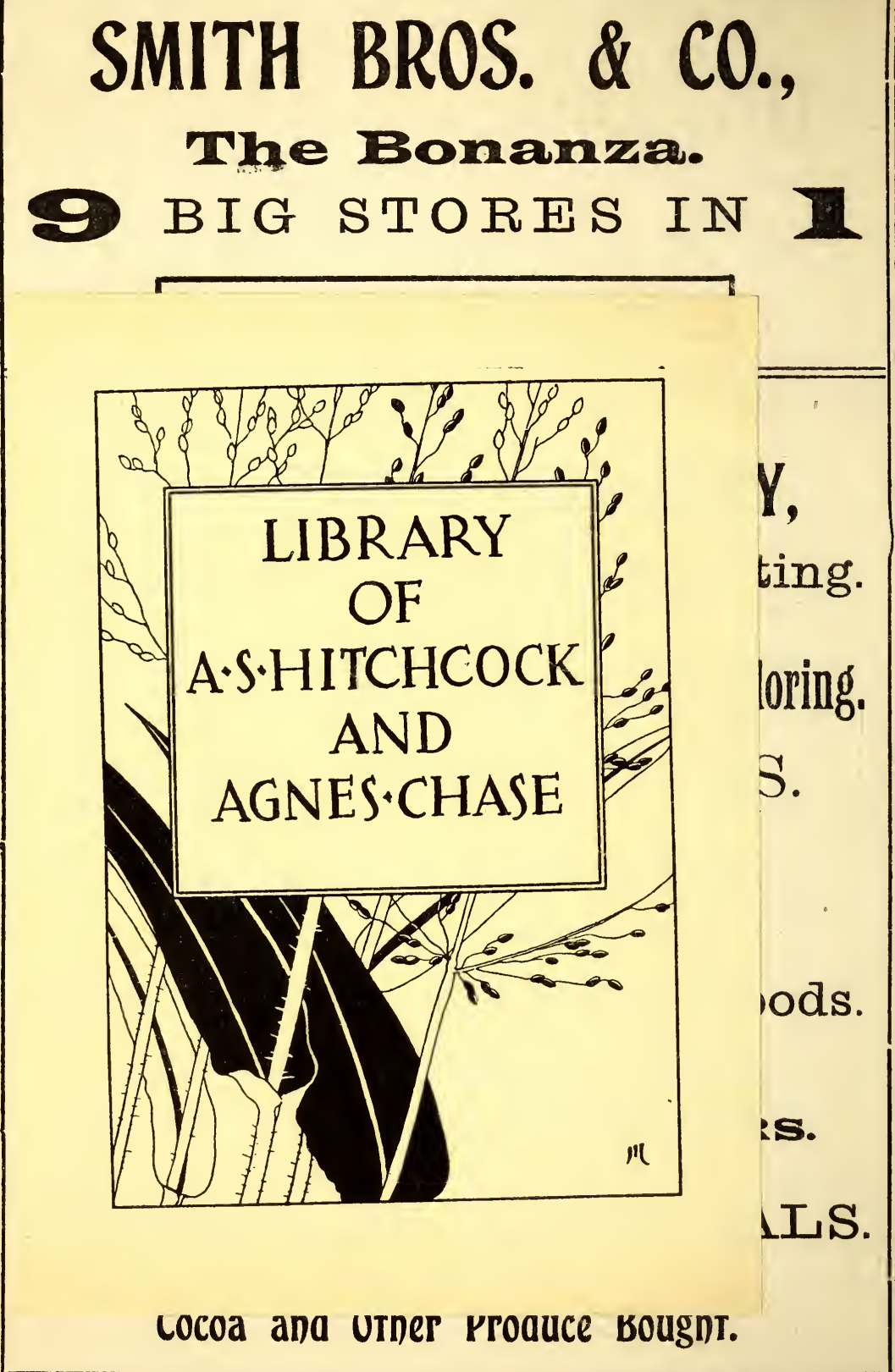

FIRE, LIFE \& MARINE INSURANCE AGENTS. 


\title{
Oilfields of Trinidad.
}

\section{BORING OUTFITS}

\author{
SUPPLIED BY THE
}

PERKINS MACINTOSH PETROLEUM TOOL \& BORING CO., LTD.

Improved Canadian Rigss, Combination Rigs for Wire Cable or Poles,

Steel Rigs and Derricks, Tubular Derricks.

\section{COMPLETE \\ I Drilling \\ PLANTS FOR | 0il Wells}

\section{SUPPLIED TO}

Egypt, Maikop, Trinidad, Argentine, Borneo, Burmah, Nigeria and other Fields.

EXPERIENCED CANADIAN OR GALICIAN DRILLERS EHGAGED FOR CLIENTS.

Catalogues and Estimates on Application to

\section{RANDOLPH RUST,} SOLE AGEN' FOR TRINIDAD. 


\section{STEPHENS

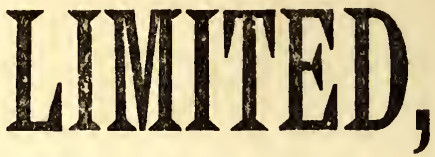

"The Stores," Trinidad,

THE BEST PLACE TO BUY EVERYTHING.

COMMERCIAL, FINANCIAL AND INSURANCE AGENTS AND PRODUCE EXPORTERS . . .

All information required by Capitalists, Settlers and Prospectors, will be gladly given by the head of the firm.

\section{HIG CLASS TAILORING.}

Gentlemen's Suits made to measure by our

EXpert EUROPEAN CUTTERS

IH SIX HOURS.
IMMENSE VARIETY OF SUITINGS,

Especially for Tropical Wear and all climates.

THE FASHIONABLE DEPARTMENT STORE OF TRINIDAD.

LADIES' \& GENT'S COMPLETE OUTFITTERS.

THE HIGH CLASS FAMILY GROCERS :

West Indian Preserves Jellies and Nuts

Cigars, Cigarettes and Wines and Spirits.
WEST INDIAN NATIVE WORK \& CURIOS, a Speciality. Enamel \& Silver Souvenir Spoons, Gold Nugget Jewellery Local Post Cards and Views Indian and Native Jewellery

THE LEADING HOUSE FOR TOURISTS \& TRAVELLERS.

\section{LONDON AGENTS:}

Messis. LADE \& CO., falcon chambers,

CASTLE ST., E.C. 


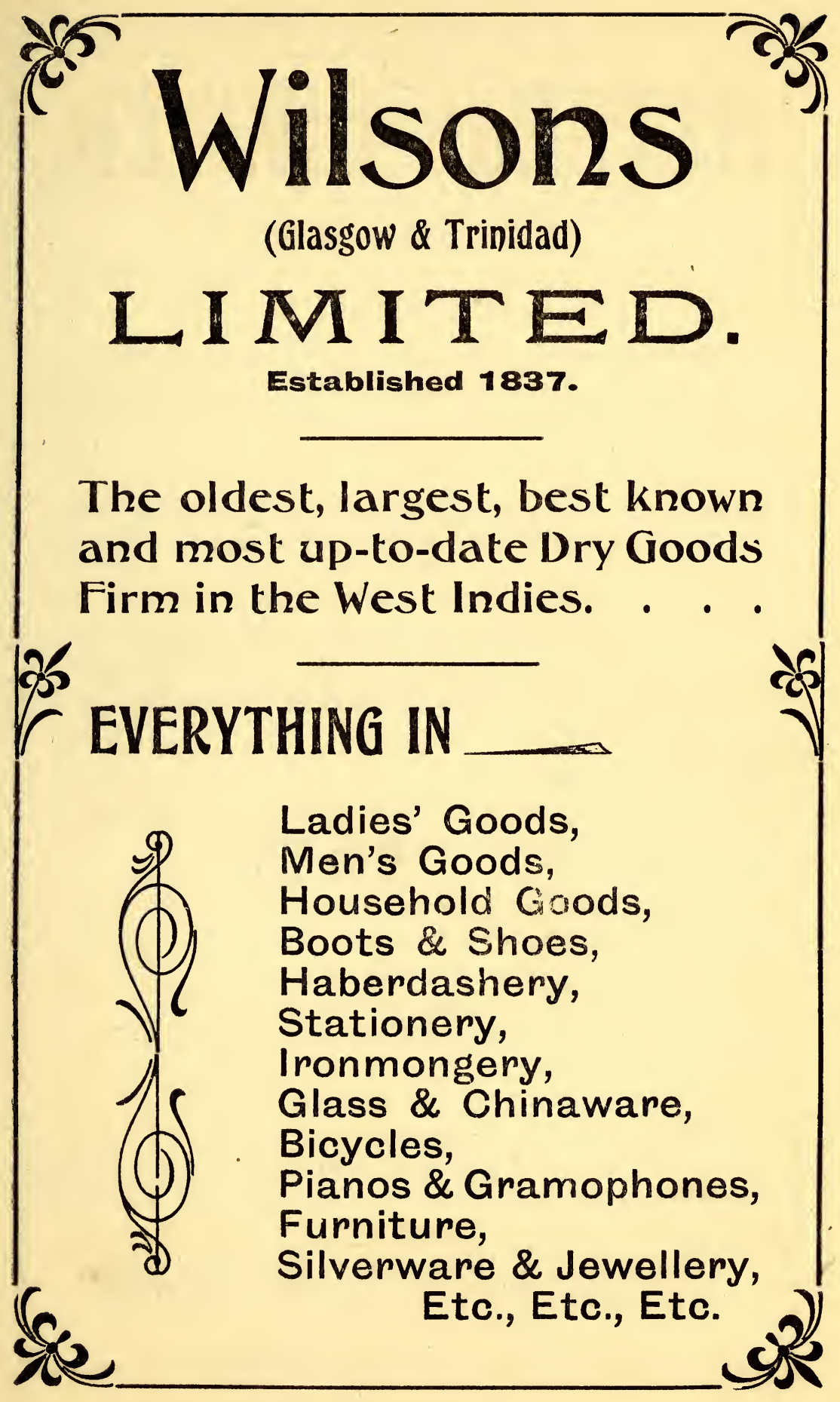




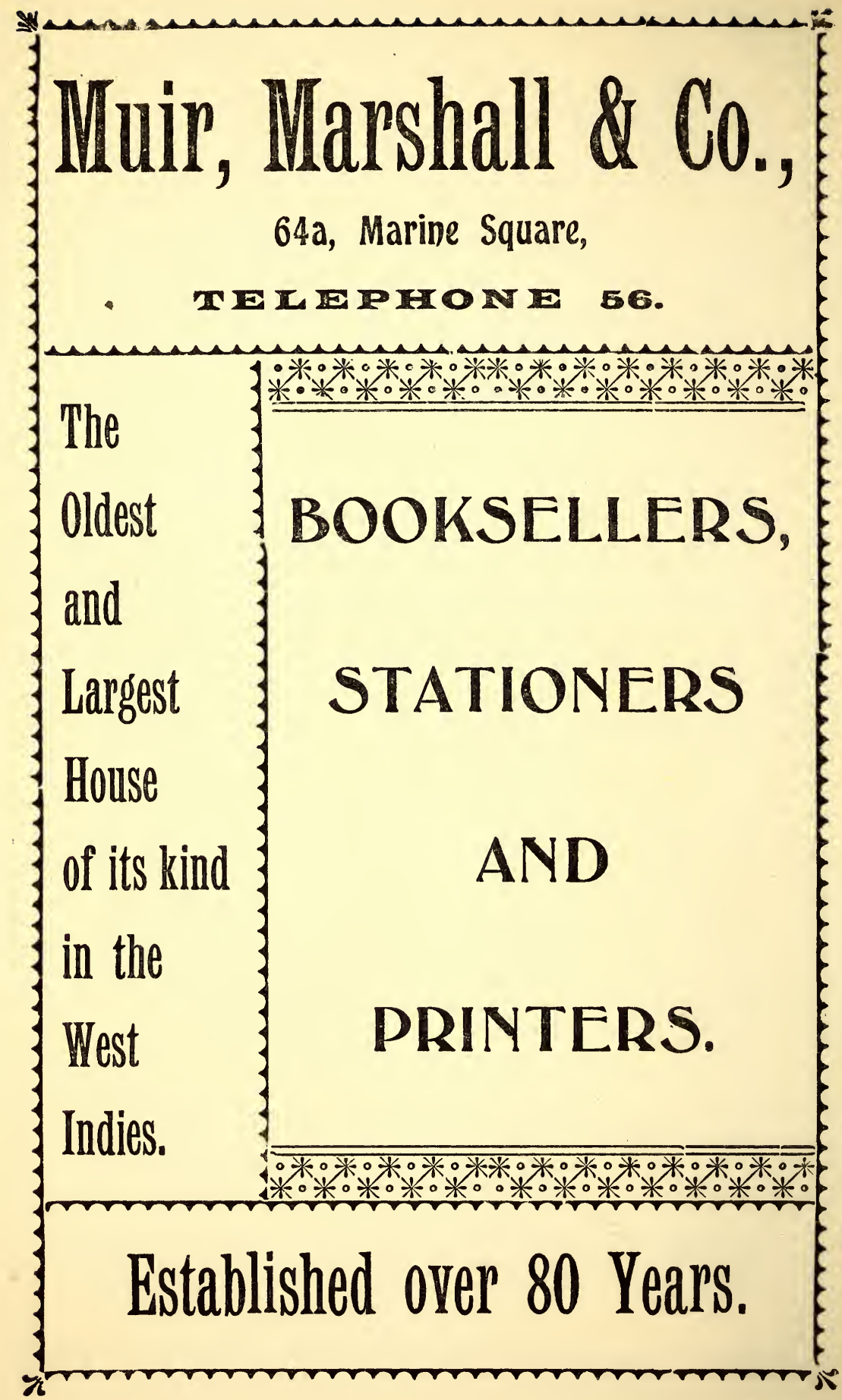


A.S. Ailckeind beptidyuchet.

TRINIDAD : THEN AND NOW. 




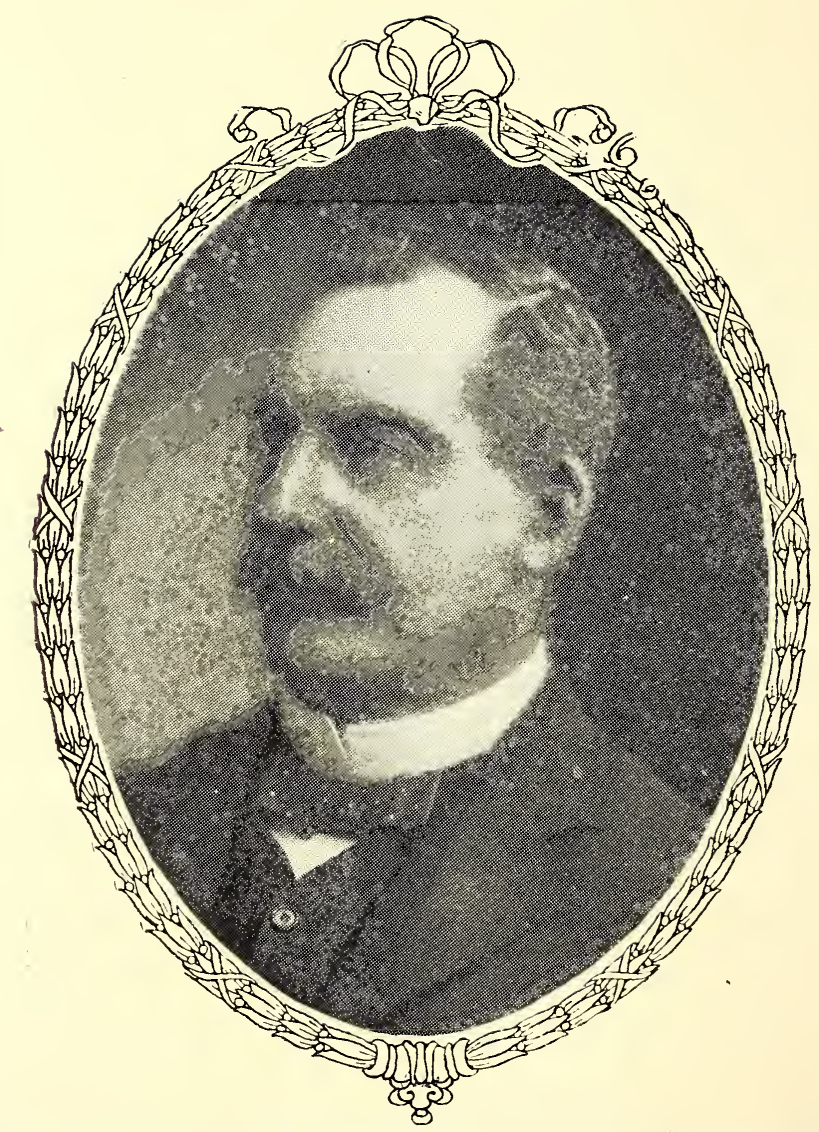

HIS EXCELLENCY SIR GEORGE RUTHVEN LE HUNTE, G.C.M,G., GOVERNOR AND COMMANIER-IN-CHIEF OF THE COLONY DF TRINIDAD AND TOBAGO. 
Being a series of Sketches in connection with the Progress and Prosperity of Trinidad, and personal Reminiscences of Life in that Island 1874-1912.

BY

\section{J. N. BRIERLEY.}

Author of

Trinidad Police Manual, 1879.

Index to and Summary of Ordinances with which the Police have to deal, 1880.

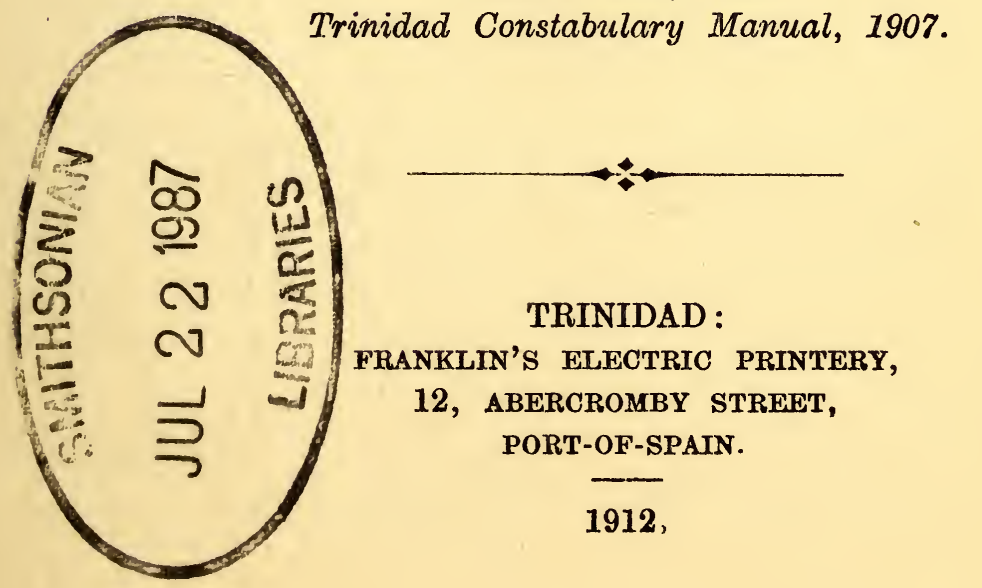





\section{DEDICATION.}

It is, I believe, usual to dedicats a book to some person from whom the writer has received some special favour, or to some patron. As I have never been under any particular obligation to any single individual, have had no patron ; and as my success in life-such as it is-is due solely to my own exertions and to the occasional help of those with whom I have associated, it struck me that I could not do better than dedicate this work to the people of Trinidad in general, from whom I have, with few exceptions, received as much courtesy, kindness, and useful assistance in my profession as I had any right to expect.

There is a passage in biblical history which reads : "Woe unto you when all men shall speak well of you !" I am glad that I have escaped that calamity.

Whenever any man filling a public position is spoken well of by every one, then you may be sure that he is not straight ; I do not mean to imply that the converse is always the case. I remember, in my early days in Trinidad, reading in one of the newspapers of those days a series of articles, following each other with weekly precision, recounting all the misdeeds (?) of a certain official and using questionable language in describing those about which a doubt 
in his favour might exist. To such an extent was this done that the governor of the day (who also came in for his share of mud-throwing, ) taking notice of it said : "There must be a lot of good in this man or he would not be so persistently abused by the press," and the result was that from that time forth the much abused official, who didn't care a jot for the abuse, began to get on.

$\mathrm{I}$, in my day, have had my traducers also and had mud thrown at me, but by keeping my eyes closed so that none of it could enter them, I was still able to see clearly ; but notwithstanding this, I also found many friends in the people of Trinidad, and to them it gives me pleasure to dedicate this book. In one of Sullivan's comic operas there is a saying "A policeman's life is not a happy one." I don't agree with it ; it is a clean, fine, wholesome outdoor life, and if he does his duty fearlessly, but withal kindly, he need fear no man.

Notwithstanding, however, that we may treat with indifference the hostile remarks of our traducers, the good wishes of our friends may carry us almost to paradise, and it is these good wishes that I ask for the fair reception and success of this book.

Before closing this dedication there is a number of men to whom I would be doing a grave injustice did I not specially thank them one and all for their courtesy and kindness towards me ; I allude to the legal practitioners of the colony from the eminent Q.C's. ; K.C's ; B.L's ; to the humblest solicitors practising in the various courts of the colony. 
To the members of the Police Force of all ranks, with whom I was so long associated, I must also express a kindly feeling, and include them among the people to whom this work is dedicated.

In dedicating this work to the People of Trinidad I am following the example of Sir Louis de Verteuil who dedicated his well written book to the Natives of Trinidad, thus to a certain extent circumscribing it, but I dedicate mine to the People thus including all, natives or otherwise. There is a passage in Sir Louis' dedication which I will take the liberty of copying and not only of copying but also of adopting them to my feeble efforts, it is :-

"I am therefore anxious that you should find it truthful, if not interesting or valuable as it might, under other auspices have been. And yet, it cannot be reasonably expected that, in treating so many and such varied subjects, no errors should have crept in ; this much, however, I can say, they are not wilful errors."

In conclusion, I express the hope that although I have struck out a new line for myself, instead of following the beaten tracks, the efforts which I have made to write of things within my knowledgealthough I have had to omit others equally important -will prove acceptable to my fellow colonists.

\section{Faithfully yours,}

\section{Port-of-Spain,}

\section{J. N. BRIERLEY.}

September, 1912. 



\section{FOREWORD.}

In the 31st chapter of the book of Job the following passage occurs : "My desire is.... that mine adversary had written a book!" Job's meaning is not very clear. Did he mean the manual labour of writing ? for in those days it was more difficult than now ; or did he mean the canvassing for subscribers ?-if he had to do so, and he may have, for we are told "there is nothing new under the sun." I think he must have meant the latter, for to me the mere writing of the book has been a pleasant pastime but canvassing for subscribers wasn't. Not that $I$ have even in that respect anything to complain of, for I was on every hand cheerfully received, liberally responded to and invariably with a smile and wishes for good luck and success in my enterprise. But yet the waiting for an interview and the fear that $I$ would meet with a refusal was not so pleasant, and I could not wish my adversaryif I have one-a more disagreeable task, except, as some one may say now that it is written, that of reading it.

THE AUTHOR. 



\section{CHAPTER I.}

\section{INTRODUCTORY.}

"There dwells a wife by the Northern Gate, And a wealthy wife is she;

She breeds a breed o' rovin' men

And casts them over sea.

The good wife's sons come home again

With little into their hands,

But the lore of men that ha' dealt with men

In the new and fragrant lands;

Kipling.

I have quoted these lines as I think them peculiarly applicable to my advent to, and residence in, Trinidad. To Trinidad as "the new and fragrant land," and to myself as one of "the good wife's sons come home again with little into their hands," -except, as in my case, the enjoyment of a good, or as the newspapers would say "well-earned," pension, which is not inconsiderable, for services rendered.

I have lived close upon 38 years-something more than half my life-in this delightful, "fragrant land," and only once, after an absence of 34 years, "come home again" to the land of my birth, to return to Trinidad after an absence of only a few months. Of wealth-except such as I have indicated- " with little into my hands but the lore of men who ha' 
dealt with men," I have obtained a goodly share, and have learned to sympathise with and understand the good, and sometimes frail, qualities of those amongst whom I have sojourned, and have made it serve as a pleasant substitute for the-to some, as they think-more profitable commodity alluded to.

The continuous residence referred to, together with the active travelling life which my profession compelled me to lead, have given me opportunities to observe passing events possessed by few, and enable me to speak not only with authority but also with certainty of the progress made and the prosperity attained in this beautiful colony within the time named.

I have frequently been asked "Why don't you write your experiences in Trinidad; they would be interesting reading ?" Knowing that the experiences my questioners meant were, to a great extent, those relating to the detection of crima, and enquiries made relative to other suspected criminal incidents, my answer invariably has been : "It is not easy to do this without hurting the feelings of many innocent people who have the misfortune to be, in some way or other, related to some whose criminal exploits I would be obliged to chronicle." I have no doubt that some of the experiences I could relate would be interesting reading to some; but there are many others to whom it would not be pleasant. I am not a blind believer in the saying De mortuis nil nisi bonum, because if this were so history could not truthfully be written, and I am afraid that if strictly adhored 
to, many that passed away would be debarred from having their names descend to posterity. I am, however, a strict believer in not unduly offending the living by alluding to the sins of their departed relatives, unless I have some foundation for thinking that they too are following in the criminal footsteps of the deceased, then, indeed, I might be tempted to depart from this rule; but apart from this latter I have hitherto refrained from writing any personal experience, or the part I played in bringing many hidden misdeeds to light. Whether I shall always adhere to this resolve is another matter : time alone will tell.

Before entering upon my personal experience and impressions, I trust, I may be permitted to give in the preliminary chapters a record of events that happened before my time : the discovery by Columbus ; its occupation by the Spaniards ; its capture and annexation by the British; its last Spanish Governor, and the stirring times under its first British Governor Sir Thomas Picton, thus affording a striking contrast to Trinidad Then and Now. I write these events not only for the information of the well read inhabitants of Trinidad-although many of them are as unacqainted with its salient features as people who live thousands of miles away from its attractions-but also for the information of those who live elsewhere. I hope they will read them and thus become interested in this small, but important spot on the face of the globe, forming a not insignificant gem in the royal diadem of him who 
reigns over the destinies of such a large portion of the human race and who, on three occasions-each of which I had the pleasure of witnessing-graced our shores by his presence.

Many attempts have been made to describe important events in the history of Trinidad, but not always in an impartial manner, and hence not successfully. It is, perhaps, difficult to do so, because the best of men allow themselves to be swayed by their likes and dislikes, particularly by the latter, and often, to a great degree, by the likes and dislikes of their friends or intimate acquaintances ; and thus often to the prejudice of the truth and to the expediency of their personal interests. Now, having no personal interests to serve, I shall endeavour to select such portions of the writings of others as appear to me to be the most reliable and free from bias. It is not my intention to write the history of Trinidadexcept so far as a record of the rapid strides made in its prospects and prosperity within my time may be considered history-I leave that task to the hands of abler men. I have read many books that, in their time, purported to describe past and passing events connected with this Colony in an impartial way,-not, however, always with success-the personal interest or bias constantly peeping out. Among these I may at once mention McCallum's series of letters relative to the governorship of Sir Thomas Picton, so full of bitter spite, and evidently written at the request and dictation of Fullarton or some one connected with him, as almost to prevent me quoting any 
passages from them ; some of them must, however, be true and I therefore extract such passages ; but, of this later.

In my selection I have come across three writers that have impressed me with the assurance that in writing what they knew of their own knowledge or learned from other sources, have done their best to be impartial, thus insuring a degree of confidence, and I therefore quote freely from them. These are Sir Andrew Halliday, author of "The West Indies," (1832-7) ; E. L. Joseph, author of " Joseph's History of Trinidad," (1830-7) ; and Sir Charles Lucas, author of "Historical Geography of the British Colonies," (1905). Mr. Joseph was a planter in this colony in the early part of the last century and evidently one who, like myself, associated with persons living and moving in the humbler walks of life. I recommend the perusal of this valuable little book to all who can procure a copy of it ; it is now extrem'ely rare. Sir Andrew Halliday was InspectorGeneral of Army hospitals and spent a good deal of his time from 1832-7 in the West Indies, particularly Barbados, Demerara and Trinidad. Sir Charles Lucas was, as every Colonial officer knows, till recently, permanent Under Secretary for the Colonies and whose position in that office has enabled him to write with authority, being acquainted, as he was, with many events not known to the general public. His work is comprised in two handy volumes-only one of which, Vol. 2, is to be found in our Public Library. Every civil servant will be the better of 
being the owner of a copy, as therein he will find much interesting information hitherto unknown to him. Sir Charles has kindly given me permission to use passages from his book.

The chapter on the discovery of Trinidad by Columbus, its possession and government under Spanish rule, and its subsequent capture by the British, has been taken from Sir Andrew Halliday, E. L. Joseph, and Sir Charles Lucas. The chapter on Sir Thomas Picton as first Governor of Trinidad, from McCallum (1803) ; "Memoirs of Sir Thomas Picton"' (1835) by B. H. Robinson, including original correspondence in the possession of Picton's family ; and Joseph. For other sources of scattered information I have had recourse to " Domestic Manners in the West Indies" (1797 to 1803) by Mrs. Carmichael-wife of the first owner of Laurel Hill and who resided on that estate for over three years; a book called " Truths from the West Indies" by Captain Studholml Hodgson (1833-8) and the "History of the West Indies" (1794) by Bryan Edwards, a splendid work in two volumes, kindly given me by the Hon. A. P. Marryat. This latter work does not treat of Trinidad because it was not, at the time of publication, a British possession, but notwithstanding this I have culled some useful facts from it particularly relative to the introduction of the Sugar Cane and Cacao into the West Indies. With such varied sources of information I think that those portions of this book which are written other- 
wise than from my personal observation will be found to be equally reliable.

\section{"Where is Trinidad?"}

During the only occasion of visiting the land of my birth, after a residence of 34 years in Trinidad, I was travelling from Holyhead to London when the question which forms the above heading was put to me by a fellow traveller. I had with me a small hand-bag-better known as a "handy-bag" -in which my papers, magazines, etc., were stored. On the bag were conspicuous the letters

$$
\text { J. N. B. }
$$

\section{TRINIDAD.}

"I see," said my travelling companion, "that you hail from Trinidad! Where is Trinidad ?"

You see, my worthy fellow colonists, that we are not such important people as we think; nor is our

"Nice little, tight little Island"

such a well-known place as you and I believe it to be.

"Where is Trinidad ?" I replied with feigned surprise; "surely you know where Trinidad is! Have you never heard of its discovery by Cristobal Colon, more generally known by the less soft-sounding name of Christopher Columbus, on the 31st July, 1498 ; or of the two romantic sayings relative to that event? One that he made a vow to heaven that he would call after the Trinity whatever land he first 
sighted; the other that he, being a deeply religious man, on seeing from the distance three hills joined together at the base was reminded of the Trinity and so he called it 'La Trinidad.' Have you never heard of the other romantic name Iëre, the land of the humming bird? Have you never heard of its fragrant spices and commercial luxuries known all over the world? Have you never seen, or swe'etened your tea or coffee with the bright yellow crystals made at Brechin Castle? Have you never tasted that superior brand of Champagne made with the help of the exceptionally fine white sugar made at the Malgretout factory? Have you never tasted the Providence or Waterloo old rum ? Have you never heard of the celebrated Usine at Ste. Madeleine with its huge works, its comfortable labourers' residences, its 80 miles of railway running to all points of the compass, which employs labourers of all nationalities, and manufactures all grades of sugar to the extent of 16,000 tons a year,one of the show places of the West Indies? Trinidad's population has not yet reached half a million although it is fast approaching it ; it is about the same size as the county of Lancashire, has good roads and a delightful climate, and, what is of still greater importance, a comparatively contented population, the most of whom require very little clothing to keep them warm and comfortable; no winter's blasts nor chilling snow to make them huddle over fires at certain seasons of the year; but instead bright warm sunshine from one end of the year to 
another. Have you never tasted Cadbury's Cocoa, grown on many of the best estates in Trinidad and supervised by one of the ablest cocoa planters to be found in the West Indies, familiarly known as Cocoa Bain? Have you never heard of the numerous cocoa plantations which send to all the markets of the world their golden beans, some over 3,000 bags of $200 \mathrm{lbs}$. each, and a host of others making from 100 to 200 bags a year; some owned by the nobility and rich commoners of England, others by wealthy planters,-many of them sons of the soil,-and others who through long residence have almost become its sons, and descending from these wealthy men by gradual gradation from the men owning 2,000 acres to the more humble peasant proprietor with his 10 to 100 acres of cocoa plantations, thus causing Trinidad to rank as the fourth largest cocoa exporting country in the world, with an annual output in some years aggregating twenty-six millions of pounds? Have you never enjoyed that peculiar beverage called a 'cock-tail,' the principal ingredient of which is the celebrated 'Angostura Bitters,' made in Port-of-Spain the principal town of Trinidad? Have you never trod the pavements or driven over the roads of New York and other cities of the United States of America and other parts of the world, made from the world-renowned Trinidad pitch ? Have you never heard of Trinidad's beautiful scenery ; its fine drives and rides over hill and through dale; its many historic spots where Britain's sons have 
shed rivers of blood and whose almost forgotten episodes once teem'ed with romance? Have you never heard of the hospitality of its hospitable inhabitants-particularly its planting class? Have you never heard of its splendid hotels not easily surpassed? Have you never heard of its beautiful health-giving climate ? I have enjoyed all and can never forget them. Have you never seen a graceful Trinidad girl dance or sing ? Well, if you have not, then from my heart I pity you. Come out and visit us and you will return to this foggy climate rejuvenated and happy. There are at least half a dozen places in the southern parts of America and the West Indies named Trinidad; but the one from which 'I hail,' as you call it, is the pearl of them all. Why, man, in what benighted part of the globe have you been hidden not to have heard of all these things so well known to the world in general !"

I was about to change the conversation when my travelling companion, who was accompanied by a lady, evidently his wife, said something to her and then turning to me said, "You asked me if I had never heard of 'Siegert's Angostura Bitters ?' and you said it is made in Trinidad. Yes, I have seen and tasted it, a few drops in a glass of sherry makes it very palatable; but we would like to know why it is called 'Angostura Bitters?' Is Angostura the name of an herb from which it is made ?"

"No," I replied, "although there is the bark of a tree, the Galipea cusparia, found in Venezuela called 
angostura, yet it has nothing to do with the name or manufacture of the compound about which we have been speaking ; it derives its name exclusively from the old town of Angostura, on the banks of the mighty Orinoco which finds its source away up in the interior of South America till it, in some places, joins the still mightier Amazon in the same vast continent. This town of Angostura changed its name to Bolivar in honour of General Bolivar, afterwards called 'El Libertador,' who with the help of a gallant band of English, Irish and Scotch generals rescued the present ' Estados Unidos de Venezuela' from the rule of Spain, some years after Trinidad was conquered by the-English, and it now forms a not insignificant republic. In honour of that event Bolivar created an order which he called" el Busto del Libertador,' a decoration which I had the honour of having had blestowed on me in May 1889 as a recognition-which the then President, Rojas-Paul, deemed that I had merited-for services rendered to the government of that republic. Dr. J. G. B. Siegert, the inventor of the celebrated ' bitters,' built a large factory for its manufacture in the old town of Angostura and named his celebrated compound after that town. His heirs carried on the business there until a short time before my advent to Trinidad, when, for some reason which $I$ do not know, they removed it to Port-of-Spain, the capital of Trinidad, where it is now carried on by his successors under the same name and flour- 
ishes as a most important industry.* When, however, we are constantly reminded of the state of turmoil and seething revolution carried on in the neighbouring republic of Venezuela, you will not be surprised that the head of this important firm should look out for, and transfer his vast business to, a country in which he would be assured of that protection which he was doubtful of receiving in a restless republic."

My companion thanked me and we changed the subject. I had told him more about Trinidad than he knew before. It is, I conceive, the duty of all good colonists to do the same whenever they get the chance.

While on this subject let me ask some of my fellow colonists: "What have you done while in the Old Country to speak cordially of Trinidad, the land of your birth or of your adoption ?" I am afraid that many who owe it a deeper debt of gratitude than even I do-and mine is great-have been found to speak disparagingly of it; or like Peter in the hour of his temptation, exclaim "I know not the man !" My fellow colonists, don't be ashamed of the country which gives you your daily bread! you have been glad to accept of its hospitality, nay, even sometimes to learn good manners from those with whom you met there and associated; don't, therefore, be ashamed when you too may be asked the question "Where is Trinidad ?" to answer like men and bear

*A separate article will be found in its place relative to this and other industries. 
testimony to its many good features, its certain progress and growing prosperity. Read any of the histories of Trinidad-not this one in particularand you will be able to speak with pride and authority of this the land of your birth or of your adoption, thus making yourself worthy of Trinidad and Trinidad worthy of you.

I recently wrote a few sketches for a small magazine, which I designated "Casual Wanderings." While I was penning the second it struck me that I might, without trenching on the rule I have alluded to, write something interesting about the progress of Trinidad during my residence here, and I began the following sketches, which I now publish in book form, at the urgent request of a number of persons who read them. I entertain the conviction that those who read them will be impressed by the tremendous strides made by this colony during the last 38 years - the period over which my experience extends. These sketches are culled from the storehouse of my memory and may, therefore, in some respects, be deficient or slightly inaccurate, but I am convinced they will, in the main, be found to be correct.

I am sorry that in relating incidents connected with the great improvements wrought in many of the public institutions it will be necessary to begin at a time when they were literally, as well as figuratively, in the mire, and in order to show the improvements and progress made they must be shown as they then were, but in doing so I shall touch as lightly on the sore spots as circumstances, consistent. 
with truth, will permit, with the object, as Kipling says, "Lest we forget."

Once, many years ago, I attended a lecture at the Queen's Royal College, Belfast. The lecturer was a learned professor from Oxford University, and the subject was "The relationship of grarnmar to the English language." In the course of the lecture he said "There are only about a dozen men in England who can write English correctly, and at the present day only two who can speak it correctly, these two are Mr. Bright and Mr. Gladstone." He further said "Bunyan's Pilgrim Progress is one of the best specimens of English extant."

If these statements are correct it cannot be expected of me, who am but an indifferently educated man, to aspire to any literary style in recording the events here set out. If, however, I be so fortunate as to express myself in a manner to be understood by those who do me the honour to read this effort, I will be satisfied. Spelling and proper punctuation are often left by greater than I am to the printer. While on this subject I will relate a little anecdote against myself having some bearing on the above. The present principal of the Queen's Royal College, being aware of my intimate knowledge of Trinidad, asked me to write a few sketches for the College Magazine. I presented him with one (see "Casual Wanderings") and soon afterwards on meeting me he said, "Your type-writer is not a good speller." I replied, "I am afraid I must plead guilty ; I cannot shirk the blame by throwing it on some other person; I do my own 
type-writing ; but have you never heard it said that bad spelling and bad hand-writing are the characteristics of all clever men ?" "Well," he replied, " if that is so my college is overrun with a number of coming clever men.",

In writing these sketches I have occasionally introduced some lighter shades to give a little brightness to the more solid matter-a theory quite in harmony with a passage in the second book of Maccabees which reads :

"For as it is hurtful to drink wine or water alone; and as wine mingled with water is pleasant, and delighteth the taste : even so speech finely framed delighteth the ears of them that read the story."

I have, therefore, endeavoured here and there to mingle a little wine with the water to render it more palatable to the taste of some, if not all, of my readers.

I will quote one more passage from Maccabees as applicable to this introduction.

"But to use brevity, and avoid much labouring of the work, is to be granted to him that will make an abridgement. Here then will we begin the story; only adding thus much to that which hath been said, it is a foolish thing to make a long prologue, and to be short in the story itself." 


\section{CEAPTER II.}

DISCOVERY BY COLUMBUS AND EARLY HISTORY.

The statement that Columbus was the first man to discover America is only a myth. There is a record of it having been discovered as far back as 499, by Hoei Shin, a Budảhist priest, who is credited with having discovered Mexico in that year, and the remains of many temples, buildings and monuments found all over Mexico and Peru, bearing signs of Buddhist art, are cited as confirmatory proof of this.

The next oldest claim, after the Chinese, is that of a number of Irish, Scotch and Welshmen, among them being a band of monks and colonists, who sailed for that place as early as the ninth century. An interesting account taken from Ari Marson's voyage to America, whither he had been driven by stress of weather, and where he discovered an Irish community -or at least a community speaking Gaelic-settled in a part of that continent which they called great Ireland, is quoted by Beamish from Ari's famous Landnamabok in proof of the existence of this colony.

Next appears Red Eric, a Norseman, who on account of his murderous brawls, had been expelled from Norway. He settled for some time in Lapland, but not being well received there he went in search 
of more congenial shores, and having landed on the northern part of America he and his companions settled there for a time, meanwhile exploring a part of the country which so pleased him that he returned after a few years, describing the land as green, fertile and well suited for colonization. So effective was his description of this new country (in 985 ?) that he persuaded a number of his countrymen to accompany him, among them being his son Leif. Thirty-five ships, fully equipped for such an undertaking as this also set forth with him, of which twenty one were never heard of again.

This was the beginning of genuine colonization in the north of that vast continent. In the year 999 Leif returned to Norway ; after which he again returned to the new country taking back with him a fresh number of immigrants and the first Christian missionary.

The discovery of this new land excited great interest in the family of Eric. Thorfinn, his second son, was urged by his wife, Guirida, and other members of his family to undertake a voyage to the newly discovered country. Accordingly in the spring of 1007 he, his wife, his brother-in-law, Thorvald (who had married Freydisa one of Eric's daughters), and his wife, and associates numbering 140 embarked in three ships one of which was commanded by Thorvald. They took all kinds of live stock with the intention, if possible, of colonising the country. Having at length reached the shores of this new world in safety they were joined by some of those who had 
remained behind; they coasted southward till they came to a place where a firth penetrated far into the country, and up which they sailed. Landing on an island they made preparations for a winter's residence, and from time to time explored the neighbouring shores in all directions. They found the country beautiful; with abundance of growing wheat and vast pasture lands.

In the course of the season Guirida, the wife of Thorfinn, gave birth to a son, who was called Snorre, the first child of European descent born in America. In course of time, Eric and his son Leif having died, the remaining members of this family returned to their home in Europe where they settled, and Snorre became the ancestor of many distinguished persons, amongst whom was Thorvaldsen, the great sculptor. Leif had called his place Vinland in consequence of the large quantity of Vines bearing abundance of grapes, and also well stocked by numerous fruit trees, and by that name it was known for many years.

From this period, we hear no more of this northern colony in America till the year 1059 when an Irish or Saxon priest went there for the purpose of converting the colonists and natives to Christianity, where he was murdered by the natives.

In the latter part of the fourteenth century two Venetian navigators in the service of a Norman prince of the Orcades, are said to have visited Vinland and there found traces of the colony left by the Northmen of Red Eric's time. From this time to the discovery of the New World by the Cabots, and a few 
years later by Columbus, there was no communication between Europe and America.

Although Columbus was undoubtedly, so far as we know, the first European who discovered the numerous and important West Indian Islands, yet he cannot claim to have been the first to discover America. That, as I have shown, was the work of a number of other persons, and at various times, but even to come down to his day he was anticipated by the Cabots, father and son, fully two years before.

John Cabot and his son Sebastian were Venetian merchants settled in Bristol. In March 1496, John Cabot prevailed on Henry VII. to allow him to fit out an expedition at his own expense to go on a voyage of discovery. The King ordered a patent to be made in Cabot's name with the exclusive right so far as his English subjects were concerned, to him and his family for three years. He fitted out his expedition, and with a fleet of five ships set sail on his voyage of discovery accompanied by his son Sebastian. They discovered the far north continent of America in the neighbourhood of Labrador and returned to England. He again obtained another patent from the King ; this time the King undertaking to pay part of the cost of the fresh expedition. This expedition was commanded by Sebastian Cabot, who annexed that vast continent from the extreme north down to the latitude of Maryland or Albemarle Sound. Want of provisions induced him to return to England.

In the history of maritime enterprise in the New World, the achievements of John and Sebastian 
Cabot, are in boldness, success and results second only to those of Columbus, and yet although Sebastian succeeded in giving a new continent to England, no one knows his burial place. Such is fame !

This in brief is an account of the different occasions and some of the various people who discovered America before Columbus, as taken from the 22nd Vol. of "The Historian's History of the World" (pages 401-454.) It is very interesting reading to anyone who will take the trouble to read it. I have a special object in mentioning it, and that is to try, if possible, to give an origin to the fair people whom Columbus found inhabiting the West Indian islands, including Trinidad, they being so different in every respect from the natives found on the Mainland. My theory, and, perhaps, it is not original, is that these people were descended from the original Irish, Scandinavian, Scotch and Welsh settlers whose discoveries I have briefly set out; and the following passages which I quote in full will, I think, bear out this suggestion.

"The Jesuit missionaries inform us that on their visits to these people they found the cross, a knowledge of the stars, a superior kind of worship, a more ingenious mind among the inhabitants of the coast which is thought to have been colonized from Greenland. They even assure us that many Norwegian words are to be found in the dialect of the people. The causes which led to the destruction of the settlers were probably similar to those which produced the same effect in Greenland." 
"A handful of colonists cut off from all communication with the mother country, and consequently deprived of the means of repressing their savage neighbours, could not be expected to preserve always their original characteristics. They would either be exterminated by hostilities or driven to amalgamate with the natives : probably both causes led to the unfortunate result."

That Columbus was the first European who discovered Trinidad, so far as we have any record, is an undoubted fact; but that he also found it inhabited " by a well-formed race with long hair and fairer complexion than any Indians hitherto seen," is also certain. He called these places of his discovery the "West Indies" because he believed them to be near to India.

The discovery of a new hemisphere,-hitherto only suspected by the greater part of the inhabitants of Europe-by Cristobal Colon, or as he is now familiarly ealled Christopher Columbus, and the progress of the Spaniards in the conquest of it, has been deservedly the theme of a long series of histories in the several languages of Europe. This subject has from time to time been resumed and illustrated by a host of writers, some of eminence and some not; some from their personal knowledge but the majority from books which they have either read or copied from as they wrote. Others have also written after a residence of a few months or as many days-in some cases, after passing through, as a tourist might. And it has been 
rather a misfortune than otherwise, that many of these writers should have written as they did, for in the number of books and series of sketches published from time to time, such lamentable ignorance has been displayed in writing of the customs and manners of these islands and their inhabitants, and such wrong impressions made as will never be entirely eradicated, even though dozens of books be written proving the contrary to be the case. Although it is not my intention to attempt to write a general history of the West Indies, or to tread again over the beaten track by a long recital of occurrences relative to the West Indies in generalof which the great majority of people are not ignorant-still as it is possible that some of my reader's may desire to know more about them than they do at present, I trust the others will forgive me if I endeavour to give a brief summary of a few events common to all, which have some bearing on Trinidad.

Shortly after the West Indies were discovered by Columbus, and the Spaniards began to take possession of them, the news of the discovery of this socalled New World spread like wildfire, and every leading European nation wanted to have " a finger in the pie"** and so swarmed towards it like flies. The Spaniards, however, tried to restrain this, to them, unpleasant desire. Mr. C. H. Haring in his book, "The Buccaneers in the West Indies in the 17th Century," gives some interesting facts, which I will occasionally quote.

* See the reference to the voyage of the Cabots, page 60 . 
"At the time of the discovery of America the Spaniards were, perhaps, less fitted than any other nation of Western Europe for the task of American colonization. Spain was neither rich, populous, nor industrious. Her long continuous warfare with the Moors had not only given her little leisure to cultivate the arts of peace, but had taught her to acquire a disdain for manual work, which helped to mould her colonial administration and influence all her subsequent history. And when the termination of the last of these wars left her mistress of an united Spain, and the exploitation of her own resources seemed to require all the energies she could muster, an entire new hemisphere was suddenly thrown upon her, and given into her hands by a papal decree to possess and populate. Instituting at home an economic policy which was almost epileptic in consequence, she found her strength dissipated, and gradually sank into a condition of economic and political impotence."

The arrogant assumption of the Spaniards of a divine right to one half of the New World-a certain pope having given the other half to Portugal*-and their consequent monopoly of trade, could not for a moment be tolerated by the enterprising mariners of England and France, who banded themselves together for mutual defence and for the plunder of the common enemy. This state of matters soon brought a host

* Pope Alexander VI.-drawing his pen through the centre of the Atlantic, as depicted on the map-in his famous Bull of 4th May, 1493, decreed all herthen nations to the East to belong to Spain, all to the West to Portugal. 
of adventurers to the West Indies. An account of Trinidad Then and Now, would not, in my opinion, be complete which did not give a brief resumé of the adventures and romantic doings of that class of adventurers, generally known as sea-rovers, freebooters, buccaneers and corsairs, who played so conspicuous a part not only in the history of Trinidad but also of the West Indies in general. Fortunately Trinidad suffered less from their depredations than any other of the West Indian islands ; but as subsequent events show, they, indirectly, contributed a striking part to its early history under British rule, for when they were driven from other islands, these pirates made it their rendezvous for committing depredations on them which eventually led to the capture of Trinidad by the English.*

Jamaica was discovered by Columbus in 1494, and was for a short time taken possession of by the Spaniards, but finding greater attraction on the mainland they, after an attempt to establish a colony, deserted it, leaving behind them a large quantity of stock, which in course of time, running wild, gave rise to the term "Buccaneer,"-afterwards merging into "pirates and free-booters."

Again quoting Haring : "In the second half of the sixteenth and the early part of the seventeenth centuries, strangers who visited the great Spanish islands of Hispaniola, $\dagger$ Jamaica or Porto Rico, usually remarked the extraordinary number of wild cattle and boars found roaming upon them. These herds

* See Instructions to Abercromby, page 39. + Hayti. 
were in every case sprung from domestic animals originally brought from Spain. For as the aborigines in the Greater Antilles decreased in numbers under the heavy yoke of their conquerors, and as the Spaniards themselves turned their backs upon the Antilles for the richer allurements of the continent, less and less land was left under cultivation ; and cattle, hogs, horses and even dogs ran wild, increased at a rapid rate and soon filled the broad savanas and deep woods which covered the greater part of these lands." "

"In course of time we find in Hispaniola and Jamaica scattered groups of hunters, mostly English and French, who gained a rude living by killing wild cattle for their skins, and curing the flesh to supply the needs of passing vessels. The origin of these men we do not know. They may have been deserters from ships, crews of wrecked vessels, or even chance marooners. In any case the charm of their half-savage, independent mode of life must have attracted others, and a fairly regular traffic sprung up between them and the ubiquitous Dutch traders whom they supplied with hides, tallow and cured meat, in return for the few crude necessities and luxuries they required.'"

" The term 'buccaneer' though usually applied to the corsairs who in the seventeenth Century ravaged the Spanish possessions in the West Indies and South Seas, should really be restricted to these cattle-hunters of Hispaniola and Jamaica. The flesh of the wild-cattle (when killed) was cured by 
the hunters after a fashion learned from the Caribee Indians. The meat was cut into long strips, laid upon a crate of hurdles constructed of green sticks and dried over a slow fire fed with the bones and trimmings of the hide of the animal. By this means an excellent flavour was imparted to the meat and a fine red colour.* The place where the flesh was smoked was called a 'boucan,' and the same term, from the poverty of an undeveloped language, was applied to the frame or grating on which the flesh was dried. In course of time the dried meat became known as 'viande boucanée,' and the hunters themselves as 'buccaneers.' When later circumstances led the hunters to combine their trade with that of piracy, the name gradually lost its original significance and acquired, in the English language, at least, its better-known meaning of corsairs or freebooters. The French adventurers, however, seem always to have restricted the word 'boucanier' to its proper signification, that of hunter and curer of meat; and when they developed into corsairs, by a curious contrast they adopted an English name and called themselves 'flibustiers" "-which really means free-booters.

"Between the hunter and the pirate no impassable line was drawn; and soon the same person combined in himself the occupation of cow-killing and cruising, varying the monotony of the one by

* Large quantities of meat, cured in a similar way, called "tasso,"-in Spanish tassajo-is an article of commerce between here and Venezuela; as I write it can be seen hanging outside the stores in Almond Walk-or, as is now named, Broadway. 
occasionally trying his hands at the other. In either case he lived at constant enmity with the Spaniards. With the passing of time the sea attracted more and more away from their former pursuits. Even the planters who were beginning to filter into the new settlements found the attraction of 'coursing' against the Spaniards to be irresistible. Great extremes of fortune such as these to which the buccaneers were subject, have always exercised an attraction over minds of an adventurous stamp. Fortune, if fickle one day, might the next bring incredible bounty, and the buccaneer who sweltered in a tropical sea, with starvation staring him in the face, dreamed of some day rolling in the oriental wealth of a Spanish argosy."

Such were the times in which these rude men lived; they were encouraged by Kings, Queens, Princes and noblemen of the different nations opposed to Spain, and it was no wonder that all who could indulged in it. On the continent Cromwell allied himself with France against England's former enemy Spain, and demanded that free commercial intercourse should be allowed by Spain between England and South America, while also stipulating the entire immunity of English subjects from the jurisdiction of the Inquisition. Spain retaliated by declaring war, and inflicted considerable damage on English shipping. Cromwell thereupon sent to the West Indies, under Penn as Admiral, and Venables as Commander of the land forces, a fleet of ships which succeeded in taking Jamaica, which ever 
since has remained a British possession. This did not, however, check the depredations of the buccaneers, but on the contrary, for a time at leastduring the whole of Cromwell's protectorate-they seemed rather to increase than diminish their hardihood, and love of adventure gave additional impetus to their depredations, for we find in later years the Governors of Jamaica being by turns free-booter and Governor, sometimes with authority sometimes without.

"To dominate the Spanish trade routes was one of the principal objects of England's policy in the West Indies. This purpose is reflected in all Cromwell's instructions to the leaders of the Jamaican design, and it appears again in his instructions of 10th October, 1655 to Major-General Fortescue and Vice-Admiral Goodson. Fortescue was given power and authority to land men upon territory claimed by the Spaniards, to take their forts, castles, and places of strength, and to pursue, kill and destroy all opposed to him. The Vice-Admiral was to assist him with his sea forces and to use his best endeavours to seize all ships belonging to the King of Spain or his subjects in America."

For many years after this, until a better understanding was established between England and Spain, this state of things continued. They were peculiar times, and hence the mentioning of these incidents will, in a future chapter, show their relationship to after events in Trinidad. The subject is very fascinating and one would like to linger over it, 



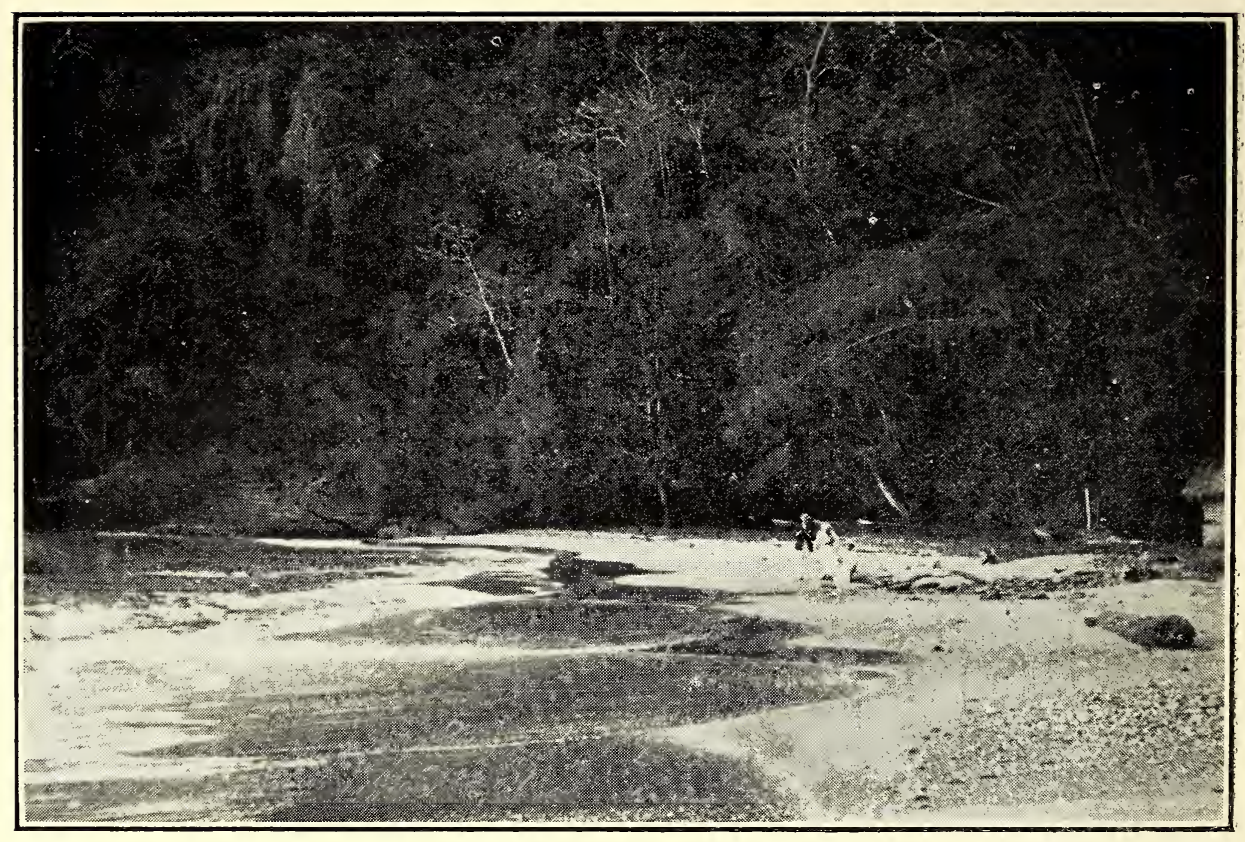

MACQUERIPE BAY.

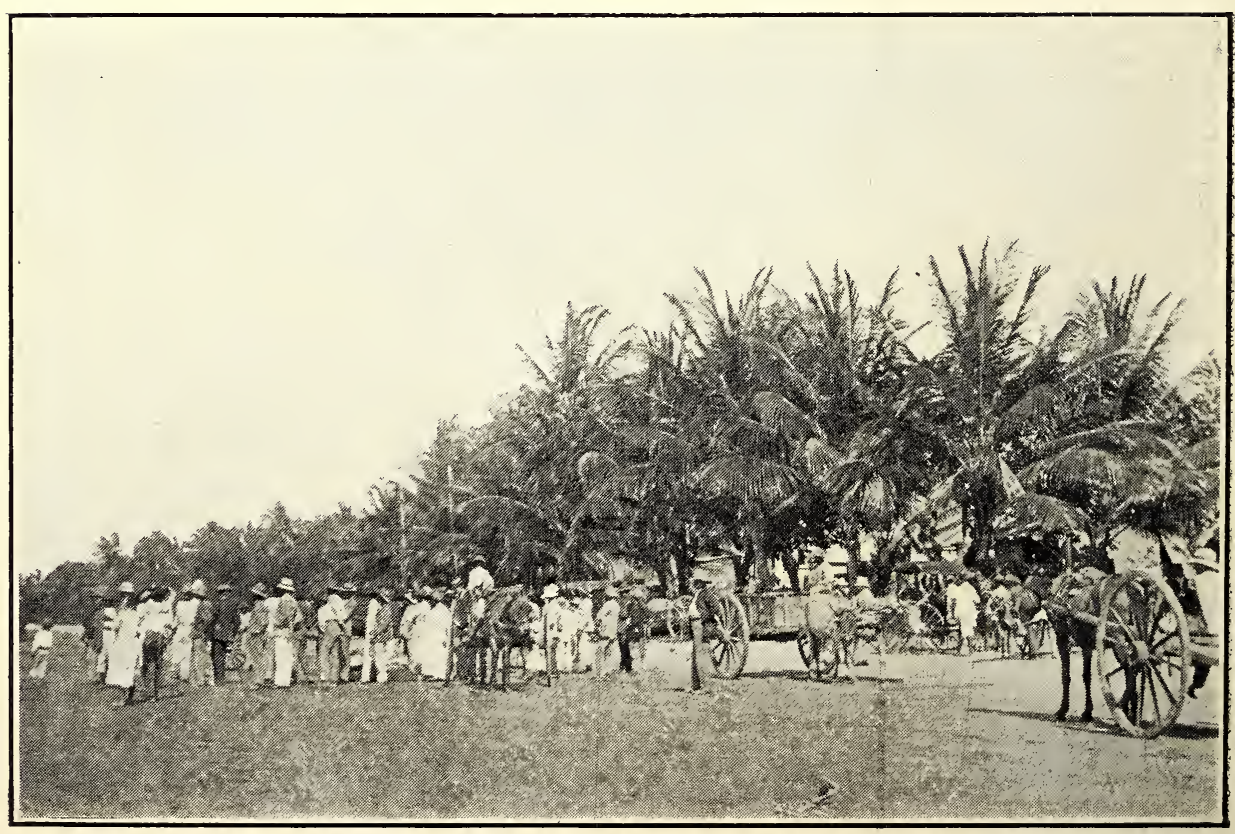

CEDROS BEACH. 
but to do so would take up too much of the book I have set out to write.

The buccaneers or free-booters mainly confined their depredations on the small commerce of Trinidad-as it then was-to attacks from outside the gulf. They had their rendezvous in a series of small but well-sheltered bays-sufficiently large for their small ships,- - on the north coast, behind a group of little islands at the places now called La Vache and Balata bays, between the North-post and Maracas bay, from either of which, by climbing the hills behind them, they were able to have a good look-out. It is probable that their reason for keeping outside the gulf was the difficulty, at certain times of the year, of either entering or leaving it, whereas from the positions named they could always avail themselves of a better offing and a favourable wind, hence they made it their base of operations.

Even ships carrying the Spanish mails anchored in Macqueripe Bay on the north coast, instead of sailing through the Boca up to Port-of-Spain,- - the mails being carried overland through what is known as "Tucker's Valley," which accounts for the fine broad road that runs through it.

Although there is not much recorded of the doings of the buccaneers in this island, there is, however, a record of a buccaneer named Teach(called by Joseph, Tench-nicknamed 'Black-Beard,' a native of Bristol) making frequent inroads into Trinidad.* There is also an account that early in

* Joseph, p. 198. 
the year 1677 the Marquis de Maintenon, Commander of the French frigate La Sorciere, aided by some French filibusters from Tortuga ravaged the islands of Margarita and Trinidad.*

A nice little rendezvous for buccaneers, freebooters, corsairs, or pirates-call them what you will -was at one time established in a small bay on the south side of Gaspar-Grande, $\dagger$ for the purpose of intercepting the small trade between Port-ofSpain and the Venezuelan coast. It was so hidden that it could not be seen by approaching vessels till it was too late to protect themselves from attack. A lookout man was placed on the top of the hill overlooking the bay, and on the approach of an incoming or outgoing ship he at once gave the signal, when at the opportune moment the pirates made their attack. This little bay still exists, but is not so deep as in the days alluded to. It has frequently been pointed out to me by members of the Tardieu family, who at one time carried on a large and lucrative business in fishing; they were the owners of several whale-fishing depots, and the tanks in which the whale oil was stored can still be seen on the western point of Gasparee. This little " pirates' bay" now looks peaceful and innocent, yet few would think that it was, in bye-gone days, the resort of desperadoes.

There are two statements relative to Columbus' first visit to Trinidad with which I do not agree.

* Haring, p. 222.

i Gasparee. 


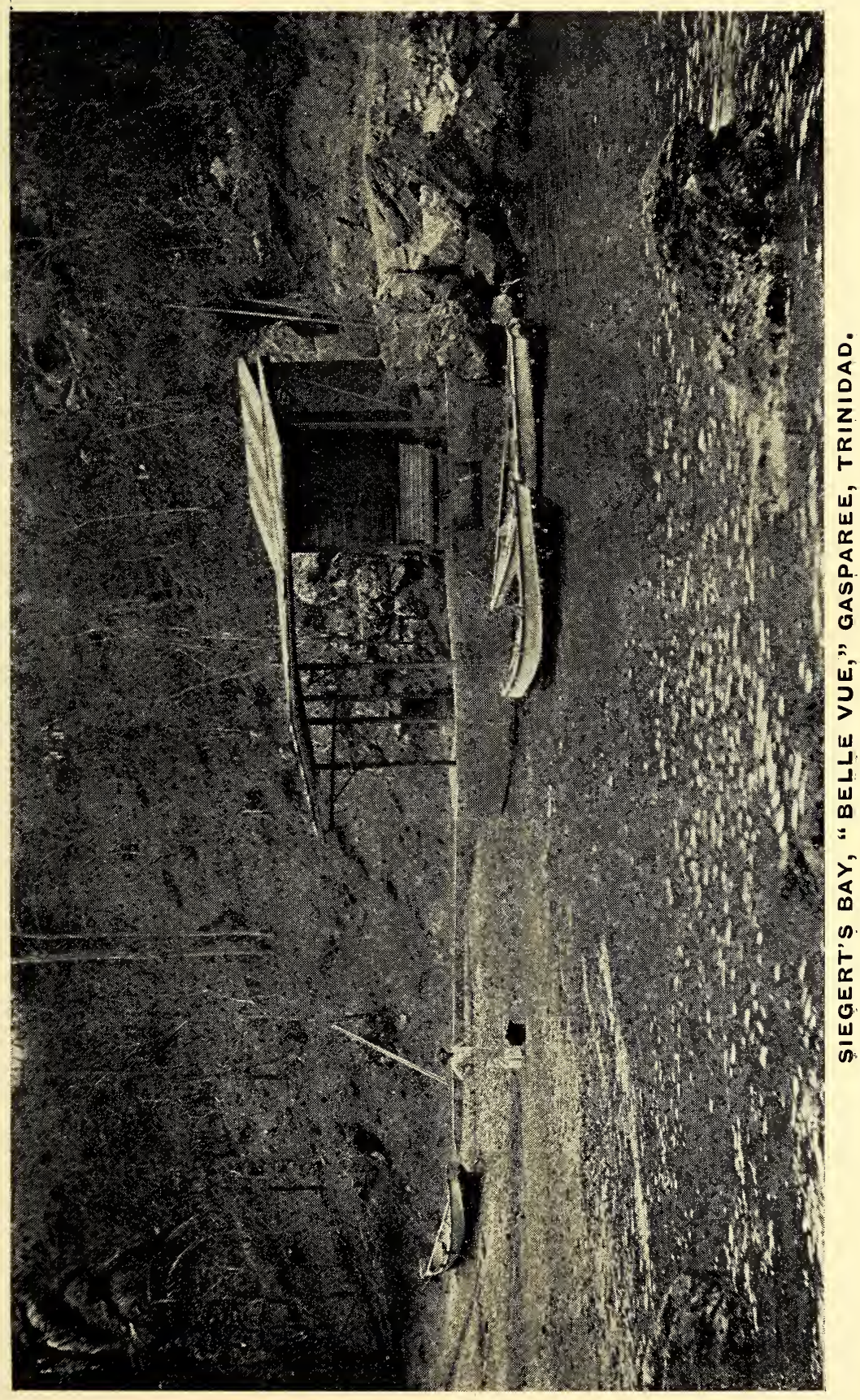



The first is that the three hills said to have been seen by him when approaching Trinidad are not the socalled "Trinity Hills" at Moruga. My contention is that he could not have seen these hills coming from the direction that he must have been sailing from in his course from Spain.

One account of his so-called discovery is that he sighted Tobago and Trinidad on the same day. Long before I had read this account-which is but recently -I was, from my intimate knowledge of the whole coast of Trinidad and Tobago, of the opinion that this must have been so, and that the three hills which he did see were the three prominent and high spurs of El Tucutche on the north coast of Trinidad. And in this view I have frequently been supported by captains of the coastal steamers with whom I have sailed at least fifty times.

The other statement with which I disagree is that Point Arenal, where Columbus is said to have anchored, is not Point Icacos but Point Erin, about 20 miles to the East of Point Icacos. For this assertion I have the authority of an old descendant of the Lett family-of Irish descent-who were the first Europeans to settle in that quarter, and hearing the natives call it Arenal, and, struck by the similarity of the pronunciation of Arenal to Erin, called the district Erin, and Erin it has since been called. I often spent hours talking to this old man, who had a good memory, and from him learned many interesting old facts and legends. 
The district now known as Erin was more likely to have been inhabited by the aborigines of Trinidad than Icacos, as Erin was a far more healthy locality and had a better supply of water. Icacos must in those remote days have been a pestiferous swamp, because to this day it is largely surrounded by lagoons and swamps. Another matter of importance to the Indians of that district was that they were in direct communication with the Indians on the Orinoco, one of the numerous mouths of which lies directly opposite Erin about 14 miles distant and can be seen even from the lowest point of Arenal, or, as I say it is now called, Erin. That a commerce was kept up between the Indians of Trinidad and those of the Orinoco is self evident because, although growing less every year, it is still kept up by the Guarahoon Indians coming over to trade with Erin, and thence round by sea to Cedros, La Brea and San Fernando.

With these two exceptions I am willing to agree with the other accounts given. I hope I will not be considered presumptuous in differing from these learned men who have written of Trinidad, but it must be remembered that I have been there and many of them have not ; besides, my professional training has taught me not to accept every thing stated to me as facts when $I$ have the means of verifying their correctness or otherwise for myself.

There are three different accounts as to why Columbus called it "La Trinidad"-meaning the Trinity. One is that he resolved to name after the Trinity the first land that he saw ; another that he 
called it so on account of the three hills which he saw joined in one at their base ; and the third because he sighted it on Trinity Sunday. I suppose there are people who by calculation would be able to tell whether the 31st July, 1498 was Trinity Sunday, but I am unable to do so, and I have no inclination to try; after all, what does it matter ? either of them may be correct. But the popular theory that the three hills which either Columbus or one of his sailors first saw from the mast of one of his ships, were the three so-called Trinity Hills on the south coast of Trinidad, in the Ward of Moruga, is one that I do not agree with.

After my two attempts at correcting former narrators, I will leave the task of further retailing the events of Columbus' visit to Trinidad to other writers whom I shall quote ; after all, it is of little importance. It was, however, at the time of his arrival, thickly inhabited; not, as some writers say, by the Caribs, but by the Aruacques (or Arrowauks) and Chaimas, whose origin is not known;-except the theory which I propound at page 20 be accepted.

"Passing through the 'Serpent's mouth' he entered the great land-locked Gulf of Paria. Here he coasted along the shore and treated with the Indians, obtained from them specimens of pearls, which subsequently rivalled the gold of Hispaniola in bringing over to the New World all the scoundrels of Spain; he finally sailed out into the ocean by the northern strait which he named the Boca del Dragon- Dragon's Mouth.'," 
"He found it inhabited by a race of fine physique, which Sir Robert Dudley, a hundred years later, described as ' a fine shape gentle people.' Thus he gave Trinidad to the world with a good character in all respects, and Europeans first knew it as a fertile, inhabited, and partially cultivated island."

"Whoever the natives of Trinidad were, they appear, like the inhabitants of Hispaniola, not to have been Caribs, for Dudley says that the latter were 'man-eaters or cannibals, and great enemies to the islanders of Trinidad." H Had they been Caribs, as sturdy and savage as the natives of Dominica or St. Vincent, they would have made short work of the Spaniards who found their way to Trinidad."

"At the beginning of the sixteenth century Spaniaras appear to have resorted to Trinidad for man-stealing, and an account is given by Las Casas of a horrible raid made on the natives, about 1510 , by one Juan Bono, a slave-catcher in the employ of the authorities of Hispaniola. About 1532 a more definite attempt was made to conquer the Indians and form a colony by a man named Sedeño (probably merged into Centeno), who obtained a royal licence for that purpose, as well as the appointment of Governor and Captain-General of the Island (which shows that he was a man of considerable position). He built a fort, but met with resistance by the natives, and though, in consequence, a decree was issued by the Council of the Indies declaring it to be lawful to make war upon the Indians and

* It is cven said that, a tribe of them was introduced into Trinidad for the purpose of exterminating the aborigines. 
reduce them to slavery, his followers drifted away to the mainland, and his scheme came to nothing."

"Sometime between 1577-1584 the settlement of St. Joseph was founded. This town is said to have been called after a Spaniard named Don Josef de Oruña, (while there are others who say it was called after Joseph, the husband of the Virgin Mary). St. Joseph is six miles from the coast and is backed by a high range of hills to the North. East, West and South, it commands a splendid view of the surrounding country* and was evidently selected by the few colonists, conscious of their weakness, as a site out of the way of free-booters and buccaneers, then so numerous in West Indian seas. Their outlet to the sea was where the present capital, Port-of-Spain, now stands."

Sir Walter Raleigh, somewhere towards the end of March, 1595, called at Trinidad on his way to explore the banks of the Orinoco and to search for the fabled riches of Guiana. Sailing in through the Boca Grande, right across the Gulf of Paria, he came to the point where La Brea now stands, and is said to have caulked his ships with the pitch which he found there in abundance. From thence he sailed northwards and anchored off the Caroni river, which he entered with his boats, and sailed up to the place where the St. Joseph river enters itself into the Caroni-in those days a considerable river. There he found a mud fort occupied by a small garrison of about twenty soldiers; these

${ }^{*}$ See Casual Wanderings No. 2. 
he speedily overcame, and then going up the St. Joseph river he captured the town of St. Joseph and set it on fire. It will be observed that I do not give this account as one copied from another source; it was given to me by the late Mr. Paul Giuseppi, whose family owned considerable property in that neighbourhood,-in fact the St. Joseph river ran through his property. It was in his dwelling house on Valsayn Estate that the Articles of Capitulation of Trinidad were signed. This ancient building was only removed within the last dozen years, to make way for the present house now occupied by Mr. John McInroy, the genial and capable Superintendent of the Trinidad Government Stock Farm. Before the end of the century in which Raleigh burnt St. Joseph, Trinidad, its weakness and its advantages were well known to Englishmen. But to resume the account given by Lucas.

" So the island drifted on in Spanish hands, only not in decay because it had never known great prosperity. The Indians decreased in numbers, the survivors of slavery and persecution living in villages and missions and paying a poll tax to the government. Slaves grew cocoa for a handful of white settlers ; and subject first to the authority of the Viceroy of New Granada, subsequently to that of the Captain-General of Caracas, the colony was administered by a governor assisted by a 'Cabildo,' a small corporate body..............At length in 1780 Trinidad woke out of its sleep. A Frenchman from Grenada, St. Laurent by name, had visited the 
island two years before, and had noted its possibilities as a field of emigration. He induced the Spanish government to publish a deeree encouraging foreigners to come and settle ; and immigrants began to arrive from the Caribbean islands, most of them French, a few Irish,-for Catholics alone were admitted ; but a liberal-minded governor, Don Chacon was sent out to carry the decree into effect, and he was not adverse to Protestants. The amount of land grant was in proportion to the number of slaves possessed. Kidnapping of black men from the other islands became so prevalent that a clause in a Grenada act passed in 1784 was directed specially against this practise."

I will here leave Sir Charles Lucas, and turn to Joseph who had special facilities for seeing old documents and family papers. Writing on this point, he says- "From the cause stated, Trinidad became towards the end of last century (18th) notoriously the home of the knave and the receptacle for stolen slaves and black and coloured people who had been kidnapped and then sold as slaves but who had not been slaves in the neighbouring colonies from which they had been kidnapped. All people going from Trinidad to any of the neighbouring islands were looked upon with suspicion ; and in the island of Grenada so much was suffered from the visits of the inhabitants of this island, that a law was made expressly against them."

This might be a suitable place to insert a brief summary of this law, but I think it will be more 
appropriately quoted when I come to deal with Don Chacon as Governor of Trinidad. That not only were the people of Grenada, but also those of other islands, justified in this apparently high-handed action will also appear in the chapter on Picton.

As I like to give variety, I will now quote from Mr. H. B. Robinson's " Life of Sir Thomas Picton" (pages 34-35).

"An expedition against Trinidad had for some time been determined on ; and shortly after the return of the Commander-in-Chief (Sir Ralph Abercromby) to the West Indies, he made the necessary arrangements with Admiral Harvey to proceed at once to capture that valuable island. The Spaniards had long been in expectation of an attack, and had collected four ships of the line and several frigates for the defence, which were moored in Chaguaramas bay under protection of batteries of considerable strength on the island of Gasparee.*

" On the evening of the 16th February, 1797 the English squadron arrived off this bay; when the Admiral had observed the position of the Spanish fleet he ordered preparation to be made for the attack on the following morning. During the night, however, flames were perceived bursting from ore of their ships, which spread with so much rapidity, that in a short time the whole were consumed, with the exception of one line-of-battle ship, which contrived to escape the conflagration but was captured by the boats of the British fleet. After this disaster,

* See Casual Wanderings No. 1. 
which was said to have been caused by accident, the enemy was not in a condition to make effectual resistance; and when Sir Ralph Abercromby landed his troops in the morning, he was permitted to march into Puerto de España (now Port-of-Spain), the principal town, almost unopposed. The Governor requested permission to retreat; which being granted, and the terms agreed to, the whole island was surrendered to Great Britain without further resistance."

The following instructions from His Majesty's Government to Sir Ralph Abercromby, relative to the attack on the island of Trinidad will, I am sure, be of great interest. I have not seen it in any of the other works which I have consulted and therefore publish it. It is taken from Robinson's Life of Picton, (page 46).

"The island of Trinidad is pointed out as a source of great mischief to the British islands, being a shelter for privateers who annoy the trade, and afford an asylum for bad people of every description, who man the privateers and row boats, which make depredations upon the coasts carrying off slaves and property ; it is therefore recommended to Sir Ralph Abercrombie, if he can collect a sufficient force without exposing the British islands, to make an attack upon Trinidad, and if the force he can spare be not sufficient to keep possession after he has taken it, to make the attack notwithstanding, for the purpose of destroying or carrying away all military stores and arms that he may find there, and seize 
upon and send to England the brigands and mischievous people who have made that island their home."

The island, as already described, was taken, the Articles of Capitulation signed and Trinidad became a British colony. In order to remove some erroneous statements which I have heard made relative to the terms of the Capitulation as signed by Abercromby, Harvey and Chacon, I reproduce it in full, as copied from "Joseph's History of Trinidad," as follows :-

Articles of Capitulation for the surrender of the Island of Trinidad, between His Excellency Sir Ralph Abercromby, K.B., Commander-in-Chicf of His Britannic Majesty's Land Forces, Henry Harvey, Esquire, Rear-Admiral of the Red and Commander-in-Chief of His Britannic Majesty's Ships and Vessels of War, and His Excellency Don José Maria Chacon, Knught of the Order of Calatrava, Brigadier of the Royal Navy, Governor and Commander-in-Chief of the Island of Trinidad and its Dependencies, Inspector-General of the Troops of the Garrison, \&c., dc.

"Article 1.-The officers and troops of His Catholic Majesty and his allies in the island of Trinidad are to surrender themselves prisoners of war, and are to deliver up the territory, forts, buildings, arms, ammunition, money, effects, plans and stores, with exact inventories thereof, belonging to His Catholic Majesty, and they are thereby transferred to His Britannic Majesty in the same manner and possession as has been held heretofore by his said Catholic Majesty. 
"Article 2.-The troops of His Catholie Majesty are to march out with the honours of war, and to lay down their arms at a distance of three hundred paces from the forts they occupy, at five o'clock this evening, the 18th February.

"Article 3.-All the officers and troops aforesaid of His Catholic Majesty are allowed to keep their private effects, and the officers are allowed to wear their swords.

"Article 4.-Admiral Don Sebastien Ruiz de Apodaca being on shore in the Island after having burnt and abandoned his ships, he, with the officers and men of the squadron under his command, are included in this capitulation, under the same terms as are granted to His Catholic Majesty's troops.

"Article 5.-As soon as ships can be conveniently provided for the purpose, the prisoners are to be conveyed to Old Spain, they remaining prisoners of war, until exchanged by a cartel between the two nations or until peace, it being clearly understood that they shall not serve against Great Britain or her allies until exchanged.

"Article 6.-There being some officers among His Catholic Majesty's troops whose private affairs require their presence at different places of the continent of America, such officers are permitted to go upon their own parole to the said places for six months, more or less, after which period they are to return to Europe ; but as the number receiving this indulgence must be limited, His Excellency. Don Chacon will previously deliver to the British Comman- 
ders a list of their names, ranks, and् places which they are going to.

"Article 7.-The officers of the Royal Administration, upon the delivery of the stores with which they are charged to such officers as may be appointed by the British Commanders, will receive receipts, according to the custom in like cases, from the officers so appointed to receive the stores.

"Article 8.-All the private property of the inhabitants, as well as Spaniards as such as may have been naturalized, is preserved to them.

" Article 9.-All public records are to be preserved in such courts or offices as they are now in ; and all contracts and purchases between individuals which have been done according to the law of Spain are to be held valid and binding by the British Government.

"Article 10.-The Spanish Officers of Administration who are possessed of landed property in Trinidad are allowed to remain in the Island, they taking the oath of allegiance to His Britannic Majesty; and they are further allowed, should they please, to sell or dispose of their property and to retire elsewhere.

"Article 11.-The free exercise of their religion is allowed to the inhabitants.

"Article 12.-The free coloured people who have been acknowledged as such by the laws of Spain shall be protected in their liberty, persons and property, like other inhabitants, they taking the oath of allegiance and demeaning themselves as becomes 
good and peaceable subjects of His Britannic Majesty.

"Article 13.-The sailors and soldiers of His Catholic Majesty's are, from the time of their laying down their arms, to be fed by the British Government, leaving the expense to be regulated by the cartel between the two nations.

"Article 14.-The sick of the Spanish troops will be taken care of, but to be attended and to be under the inspection of their own surgeons.

"Article 15.-All the inhabitants of Trinidad shall, within thirty days from the date hereof, take the oath of allegiance to His Britannic Majesty to demean themselves quietly and faithfully to his Government, upon pain in case of non-compliance of being sent away from the Island.

"Done at Port d'Espagne, in the Island of Trinidad, the 18th day of February, 1797.

\section{"RALPH ABERCROMBY. \\ " HENRY HARVEY. \\ "JOSE MARIA CHACON."}

Here I will leave Trinidad at the time it became a British colony ; only adding that it was not inhabited by the Spaniards until ninety years after it became a Spanish possession, and to this fact may be attributed its present fertility ; it has not become worn out, as has been the case with many other West Indian colonies. It was, however, used by the Spaniards as " the happy hunting ground" for kidnapping the unfortunate natives and selling them into slavery. The chapter on Don Chacon as former Governor will furnish further details. 


\section{CHAPTER III.}

\section{CHRISTOPIER COLUMBUS.}

Having completed the chapter on the discoveries of America-including Trinidad-and the various facts connected therewith, I find that I have said very little about Columbus as the chief character in the incidents related; and it struck me that some of my readers might think that I have tried to belittle him, by assigning to others that credit which had hitherto been claimed for the great discoverer. I can assure such that nothing was further from my thoughts ; for were I to attempt to do so, I should certainly be laughed at. My object in writing these sketches, has been to give the reader bare facts, and to attempt either to belittle the doings of certain persons or to belaud them would have been contrary to that design.

When I mapped out the course for writing this book, I intended to confine myself to matters relating to Trinidad alone; but as I read certain authorities I came across many interesting incidents bearing on the subject under consideration, some directly, but others, it is true, indirectly, so that it was hard to separate them and therefore-if I may use the termamalgamated them. 
As I found the principal events concerning the three eminent men who played such an important part in the early history of Trinidad so interesting, I, therefore, determined to give short sketches of the career of each : of Columbus as its discoverer ; of Don Chacon as its last governor at the time of the conquest ; and of General Sir Thomas Picton as its first governor under British rule.

Of the early life of Columbus little is known. The family name in Italian is Colombo ; but Columbus gave it the latinised form of Columbus. He is, however, better known through Spanish history as Cristoval Colon. The date of his birth is uncertain, it was formerly placed about 1436, but a later date is also given. After he had become famous, sixteen towns claimed the honour of being the place of his nativity. This reminds one of a similar incident relating to Homer of whom it is said :

"Seven wealthy towns contend for Homer dead, Through which the living Homer hegged his bread."

Columbus claimed Genoa as his birthplace and there can be little doubt that this is correct. His father was probably engaged in the occupation of clothweaver or wool-comber. His career, before his first voyage, is rendered vague by radical discrepancies in the various records ; that he spent a short time at the school at Pavia is, however, well verified.

At the age of fourteen he broke off his studies to commence his naval career-not, however, before he made extraordinary progress and imbibed a taste for 
literary cultivation which he preserved during his life. We find him at an early age in Lisbon, with his brother Bartholomew, constructing sailing charts for navigators ; and it is probably this fact which led him, in after years, to conceive the idea that he would be able to find a shorter way to India than the one then being searched for, and afterwards discovered, round the Cape of Good Hope.

Portugal was at that time engaged in geographical discovery; and Columbus soon embarked in an arduous voyage to the north in which he reached the $73 \mathrm{rd}$ deg. of north latitude while others were similarly employed towards the south, both endeavouring to discover a way to India. Columbus made several voyages to England, and to the islands possessed by Spain and Portugal in the Western ocean including Porto Santo. By taking notes of everything he saw, comparing them with the existing systems, and by drawing maps and constructing globes he kept his mined fixed on the studies in which he was destined to effect so great a revolution.

While in Lisbon, he married Donna Felipa de Perestrello, daughter of one of the most experienced navigators of his time. By this marriage Columbus procured access to the charts and papers of many experienced navigators connected with his wife's family. By repeated conversations with many able geographers and sailors whom he found in Lisbon, and consulting them on the possibility of discovering a western passage to the countries Cathay (China of mediaeval times) and Zipangu (Japan) 
described by Marco Polo, the Venetian voyager. The theory-afterwards found to be wrong-which he had already formed on this subject appeared to receive confirmation by certain facts which came to his knowledge. For instance, he heard of pieces of carved wood, evidently not cut with a knife or any steel instrument, which had been carried to the coast of Porto Santo by strong westerly winds ; that other navigators had picked up canes of enormous size and many plants apparently belonging to the Old World; and th it the bodies of men were found thrown up by the waves on the shores of the Azores, who had features differing essentially from those of Africans or Europeans and who had evidently come from the west.

These things seemed to have weighed much with Columbus in his idea that by sailing west he could find a shorter way to India. It is impossible to arrive at any proper conclusion as to the time when he conceived this idea. It is certain, however, that he meditated it as early as the year 1474, though as yet it lay crude and unmatured in his mind. This is confirmed by the correspondence which he had with Toscanelli, of Florence, which took place in the summer of that year and who applauded the design which Columbus had expressed of making a voyage to the west. To demonstrate this more clearly he obtained a map partly projected according to the ideas of Ptolemy and partly according to the description of Marco Polo. While the design of attempting the discovery in the west was maturing in his mind, he made 
a voyage to the north of Europe-Iceland, the farthest point then known in that direction.

Several years elapsed before he made an effort to carry his design into execution. He was too poor to fit out the ships necessary for so important an expedition. His residence in Portugal placed him at hand to solicit the patronage of that power, but Alfonso who was then on the throne, was too much engrossed in war with Spain, for the succession of the Princess Juana to the throne of Castile, to engage in a peaceful enterprise of an expensive nature; neither was the public mind prepared for so perilous an undertaking.

In 1481, John II. having ascended the throne of Portugal, and Columbus being aware of this monarch's desire to accomplish a passage by sea to India, he obtained an audience with him, and proposed, in case the king would furnish him with ships and men, to undertake a shorter and more direct route than that along the coast of Africa-which although being searched for had not yet been discovered. He then unfolded his hypothesis with respect to the extent of Asia, describing also the immense riches of the island of Cipango, or Zipangu (Japan) the first land at which he expected to arrive.

The King of Portugal was discouraged from acceding to Columbus' project through the advice of his councillors, consequent on the cost and trouble already sustained in exploring the route by the African coast. It was referred to a scientific body who treated the project as extravagant and visionary. Still the King does not appear to have been satisfied 
with this decision. According to his historian Vasconcellos, he convoked his council, composed of prelates and persons of the greatest learning in the kingdom, and it was decided by them to pursue the route which they had already opened along the coast of Africa; this was accordingly prosecuted with new ardour and eventually with triumphant success.

What was Columbus' next step is not quite certain, but it is said that he offered his project to his native city, Genoa. That republic-Genoa was then a republic-was, however, at that time in a languishing decline and embarassed by a foreign war, and, being disheartened by her reverses, shut her ears to the proposition, which if they had listened to and carried into effect would have undoubtedly revived her waning splendour and enabled her to still hold within her grasp the commerce which she was fast losing. Anyway her crippled state of finance deterred her and the offer had to be declined.

He next offered it to Venice where it was declined also on account of the critical state of national affairs. His next effort was with Spain, where he had many interviews with the Duke of Medina Sidonia, who was tempted for a time by the splendid prospects held out ; but the very splendour threw a colouring of improbability over the enterprise and he finally rejected it as the dream of an Italian visionary. The Duke of Medina Celi hearing that Columbus was likely to apply to the King of France, and loth that such an enterprise should be lost to Spain, wrote to 
Queen Isabella, recommending it strongly to her attention. The Queen received the proposition favourably and requested that Columbus might be sent to her. He accordingly set out for the court of Spain ; but the Spanish sovereigns, Ferdinand and Isabella, were at that time too busy with other matters of state to attend to Columbus, so he had to wait While thus lingering in idle suspense, he became attached to a lady named Beatrix Enriquez, of a noble family, though in reduced circumstances; but still able to command some influence at court. Their connection was not sanctioned by marriage, yet he cherished sentiments of respect and tenderness for her to his dying day. She became the mother of his second son, Fernando, born in 1487 -whom he always treated on terms of perfect equality with his legitimate son Diego-who after his death became his historian.

The court of Spain removed to Salamanca. Columbus followed it there and succeeded in obtaining the patronage and influence of the celebrated Pedro Gonzales de Mendoza, Archbishop of Toledo and Grand Cardinal of Spain, a man of such influence as to be facetiously called by Peter Martyr, "the third King of Spain." Through his representations Columbus at length obtained admission to the royal presence, but there is no record of the particulars of this audience nor is it certain whether Queen Isabella was present on the occasion; the contrary seems to be most probable. 
Ferdinand was cool and wary and would not trust his own judgment, so the matter was referred to a body of the most learned men in Spain, and arguments from the bible were cited against it. At the very threshold of the discussion, instead of geographical objections Columbus was assailed with citations from the Bible and the Testament : the book of Genesis, the Psalms of David, the Prophets, the Epistles and the Gospels. To these were added the expositions of various saints and commentators, such as St. Chrysostom, St. Augustine, St. Jerome and a number of others, with the result that his project was condemned as heretical.

At this time he received a letter from Henry VII. inviting him to come to England, and holding out promises of encouragement. He evidently did not accept this invitation; why, it is difficult to understand, but there must have been strong hopes held out by the Spanish sovereigns to induce Columbus to decline the invitation; and there is ground for such a supposition, because he received a large sum of money from the Spanish treasurer to enable him to again attend a summons which he received from the Castillian court,-supposed to have emanated from Queen Isabella, who was a warm advocate of Columbus' proposals.

During the time he was waiting to have his project again considered he supported himself, in part, by making maps and charts, and occasionally by the liberality of the Friar Diego de Deza. It was due to the sovereigns to say that whenever he was summoned 
to follow the court from one place to another or to attend any appointed consultation, he was attached to the royal suite and lodgings provided for him, with necessary sums of money to defray his expenses.

His project was again submitted to a council of scientific men and he was directed to attend their conference. They at length reported to their Majesties, that the proposed scheme was vain and impossible, and that it did not become such great princes to engage in an enterprise of the kind on such weak grounds as had been advanced. During all this time he was exposed to continual scoffs and the very children in the streets, being taught to regard him as a kind of madman, pointed their fingers to their heads and tapped their foreheads.

Notwithstanding the unfavourable report, the sovereigns were unwilling to close the door upon a project which might be productive of such important advantages. However, Columbus was informed " that the great cares and expenses of the wars rendered it impossible for the sovereigns to engage in any new enterprise ; but when these wars were concluded they would have both time and inclination to treat with him about what he proposed."

Knowing that all further reliance on vague promises-which had so often led to disappointmentwere vain, he gave up all hopes of support from the throne, and turned his back upon Seville, indignant at the thought of having been beguiled out of so many precious years of waning existence. 
I am beginning to fear that I am making this part of the narrative of Columbus' life rather long, but just at this point it becomes so fascinating that I am loth to shorten it, for there is no part of his interesting life more romantic than that which follows on his determination to turn his back upon the Spanish court.

About half a league from a little sea-port in Andalusia there stood, and continues to the present day, an ancient convent of Fransciscan Friars. One day Columbus on foot and in humble guise, accompanied by his son, stopped at the gate of this convent and asked the porter for a piece of bread and some water for his little boy. While receiving this humble refreshment the prior of the convent, who passed at that time, being struck by the appearance of the stranger, and, observing that he was a foreigner, entered into conversation with him when he soon learned the particulars of his story, and that he was on his way to seek the aid of the king of France.

The prior was a man of extensive information and greatly interested in the grandeur of Columbus' conception, and when he found that he was on his way to France and abandoning Spain the patriotism of the good prior took alarm. Several conferences took place at the convent at which many famous mariners were present. Among these was Martin Alonzo Pinzon, the head of a family of wealthy and experienced navigators of the port, celebrated for their adventurous expeditions. Facts were related by. 
some of them in support of the theory of Columbus. In a word his project was treated with deference in this quiet cloister. Martin Alonzo Pinzon, especially, was so convinced of its feasibility, that he offered to engage in it with purse and person, and to bear the expenses of Columbus in a renewed application to the court of Spain.

Isabella having always been favourably disposed to the proposition of Columbus, wrote requesting that he might again be sent to her, and sent him a sum (that might be computed in our day at about $£ 43$,) to bear his travelling expenses, procure him a mule for the journey, and also to provide decent raiment that he might be able to appear at the court.

When he arrived there a favourable reception was accorded him, but he had to wait for some time before receiving immediate attention, as the court was then celebrating with great pomp and ceremony the memorable surrender of Granada to the Spanish arms, thus putting a stop to that prolonged war.

The war with the Moors being at an end, the sovereigns kept their word with Columbus, but he was met with severe opposition, particularly from the ecclesiastical advisers of the King and Queen, especially as to the terms which he proposed before undertaking such a stupendous voyage. These terms were pronounced extravagant and inad. missible ; he, however, would not concede one point and thus the negotiation was broken off. 
It is impossible not to admire the great constancy of purpose and loftiness of spirit displayed by Columbus ever since he had conceived the idea of his discovery. More than eighteen years had elapsed since he first made known his design. He was again grievously disappointed at this failure and determined to make his way to France, and actually started on his way with that object.

Queen Isabella, as already seen, being greatly in favour of this mighty enterprise, was interceded with and induced to send a special messenger after Columbus, who succeeded in overtaking him and persuaded him to return. On his return he was accorded another interview, and Queen Isabella, like the brave and generous woman that she was, offered to pledge her jewels to help the enterprise which was at last agreed to.

On the 17th of April, 1492, the Articles of Agreement were signed, and on Friday the 3rd of August, 1492 the expedition sailed under the command of Columbus. Reader, the record of that voyage is intensely interesting, and I am reluctant to omit it, but space compels me to do so. The remainder of the story of this first expedition will be told from extracts from his letter to Lord Raphael Sanchez, Treasurer to Ferdinand and Isabella ; it was written after his return from his first voyage and reads as follows :-

" Knowing that it will afford you pleasure to learn that I have brought my undertaking to a successful termination, I have decided upon writing you 
this letter to acquaint you of all the events which have occurred in my voyage, and the discoveries which have resulted from it. Thirty-three days after my departure from Cadiz I reached the Indian sea, where I discovered many islands without resistance in the name of our most illustrious majesty.

" To the first of these Islands which is called by the Indians Guanahani,* I gave the name of the blessed Saviour (San Salvador), relying upon whose protection I had reached this as well as the other islands ; to each of these I also gave the name, ordering that one should be called Santa Maria de la Concepcion, another Fernandino, the third Isabella, the fourth Juanat and so with all the rest respectively.

"As soon as we arrived at that which I have said was named Juana, I proceeded along its coast for a short distance westward, and found it to be so large and apparently without termination, that I could not suppose it to be an island, but the continental province of Cathay. Seeing, however, no towns or populous places on the sea coast, but only a few detached houses and cottages, with whose inhabitants I was unable to communicate, because they fled as soon as they saw us, I went farther on, thinking that in my progress I should certainly find some city or village. At length, after proceeding a great way and finding that nothing new presented itself, and that the line of coast was leading us northwards

* Now Cat Island, Bahamas.

† Named after a Spanish princess heir to the throne of Castile who became mad after the death of her husband. 
(which I wished to avoid because it was winter, and it was my intention to move southwards ; and because moreover the winds were contrary), I resolved not to attempt any further progress, but rather to turn back and retrace my course to a certain bay, that I had observed, and from which I afterwards despatched two of our men to ascertain whether there was a king or any cities in that province. These men reconnoitered the country for three days, and found a most numerous population, and great numbers of houses though small and built without any regard to order, and with which information they returned to us.

"In the meantime I had learned from some Indians whom I had seized, that the country was certainly an island; and therefore I sailed towards the east, coasting to the distance of three hundred and twenty-two miles and brought us to the extremity of it ; from this point I saw lying eastward another island, fifty-four miles distant from Juana, to which I gave the name Hispaniola : I went thither, and steered my course eastward as I had done at Juana, even to the distance of five hundred and sixty-four miles along the north coast.

"This island of Juana is exceedingly fertile as indeed are all the others; it is surrounded with many bays, spacious, very secure, and surpassing any that I have ever seen; numerous large and healthful rivers intersect it, and it also contains many very lofty mountains. 
"The convenience and excellence of the harbours in this island, and the abundance of the rivers so indispensable to the health of man, surpasses anything that would be believed by one who had not seen it. The trees, herbage and fruits of Hispaniola are very different from those of Juana and moreover it abounds in various kinds of spices, gold and other metals, but not iron.

"The inhabitants of both sexes in this island and in all the others which I have seen, or of which I have received information, go always naked as they were born, with the exception of some women.

"They practise no kind of idolatry, but have a firm belief that all strength and power and indeed all good things are in heaven, and that I and my ships had descended from thence, and under this impression was I received after they had thrown aside their fears. They are very clear of understanding, and those men who have crossed over to the neighbouring islands give an admirable description of everything they observed; but they never saw any people clothed, nor any ships like ours.

"The extent of Hispaniola is greater than all Spain from Catalonia to Fuenterrabia which is easily proved, because one of its sides which I coasted in a direct line, from west to east measured five hundred and forty miles. This island is to be regarded with special interest, and not to be slighted; for although as I have said I took possession of these islands in the name of the king, and the government of them is unreservedly committed to His Majesty, 
yet there was a large town in Hispaniola of which especially I took possession, situate in a remarkably favourable spot, and in every way convenient for the purpose of gain and commerce.

"I have already said, I saw no cannibals nor did not hear of any, except in an island called Charis," which is the second from Hispaniola, where dwell a people who are considered by the neighbouring islanders as most ferocious; and these feed upon human flesh."

During the whole time of Columbus' stay in these latitudes he never gave up the idea that he was in the neighbourhood of India or China. He did not on his first voyage come in sight of what we now know as America.

Columbus returned to Spain on the 15th March, after an absence of about seven months and a half. The news of his discoveries being known he was received with great favour at Court. The letter addressed by him to the Spanish monarchs,-from which I have given short extracts-had produced the greatest sensation at Court and he was addressed by the title "Don Christopher Columbus, our admiral of the Ocean, and Viceroy and Governor of the islands newly discovered in the Indies."

Columbus made three other voyages to the West Indies, the particulars of which it is not necessary to give. It was on his third voyage that he discovered Trinidad and caught sight of the mainland of America for the first time as already described.

* Where the Charaibees, or Caribs, dwelt. 
The following is a short account of this voyage " On the 30th of May, 1498, Columbus sailed on his third voyage with six ships. He touched at the Canaries, and despatched from thence three of his squadron direct to Hispaniola. With the other three he steered towards the Cape Verd islands. Taking his departure from this point he held a southwesterly course till he came within five degrees of the equator, where the heat of the air burst the wine pipes and water casks, and caused the crews to fear that the ships would be burned. On the 31st of July they discovered land which proved to be the island of Trinidad, at the mouth of the Orinoco. Proceeding along the shore, he obtained a sight of some of the natives, who proved very hostile and discharged showers of arrows at the ships. They had shields,the first defensive armour the Spaniards had seen in the new world. Columbus sailed through the Gulf lying between Trinidad and the mouth of the Orinoco, struck with amazement at the mountainous billows which that great stream rolls into the ocean.

"On the coast of Paria they saw more of the natives, and held friendly intercourse with them. They offered the Spaniards provisions and a sort of wine. Gold was discovered and the pearl fishery of Margarita. From this coast they sailed for Hispaniola. This was the voyage in which the Spaniards first saw the mainland of America.

It will be remembered that after Columbus' first voyage the whole European world was set agog with 
the news of his wonderful discoveries; but it was not till after his return from his second that John Cabot persuaded King Henry VII. of England to allow him (Cabot) to set out on his voyage of discovery, as related.

No matter how many people, or how many nations claim to have discovered America prior to Columbus, to him must always remain the honour of bringing it into such prominent notice as to make its discovery of real importance and value not only to the European nations in particular but to the world at large. This was no empty honour, for it also disclosed to a wondering world a man of indomitable courage and perseverance.

That the idea which first actuated him and with which idea he set out-that of reaching China, Japan or India, by a western passage-was a failure, is of very little importance, considering that he gave the civilized world a new and vast continent hitherto but vaguely dreamt of by them, and of far greater importance to the world than a short cut to Cathay, the land of his dreams.

That his voyages of discovery did not realize the profits he imagined, or that he was glaringly robbed of his proper share, matters not. This, however, is known that he lived for some years after his final return to Europe in poor condition, broken in health, maligned and abused, and died in 1506. But no poverty, no degradation, no calumny will, so long as the world lasts, deprive him of the wealth of his immortal fame. 


\section{CHAPTER IV.}

DON CHACON : TRINIDAD'S LAST SPANISH GOVERNOR.

In attempting a brief sketch of Don José Maria Chacon, Knight of the Order of Calatrava and Brigadier of the Spanish Royal Navy, as governor of Trinidad at the time of its capitulation to English arms, it will be advisable to relate a few important details not already set out. At this time, and for a long time prior to his appointment as governor, Trinidad was in a state of stupor ; it had made little progress in the art of civilizing since the days of its first occupation, in fact, if anything, it was growing gradually worse. The aborigines, a fine developed, gentle race-as Columbus, and later, Dudley described them to be-were fast disappearing from the country, either by gradual extermination or being kidnapped and sent to work as slaves in mines on the mainland,-now more familiarly known as Venezuela, Dutch, English and French Guiana-for they at that time owed allegiance to Spain.

Such was the state of Trinidad down to the time when Mr. Rome de St. Laurent arrived from Grenada, then a French colony, and conceived the idea of colonizing it by outsiders from the neighbouring islands. In consequence of which he addressed a petition to the Spanish government at Madrid to 
approve of his project. His petition was approved of and a set of conditions and rules, called the "Cedula," were framed by which this scheme could be carried out. It received the sanction of the King and court at Madrid and was embodied accordingly in the laws of Trinidad. The apparent main feature of this seemed to be that immigrants from any foreign country would be admitted free, but it contained a proviso that " all new settlers of foreign nations must make it appear that they are Catholics," -a very unwise proviso as looked upon by people of the present day.

While it admitted a number of French, Irish and Scotch, who professed the Catholic religion, it practically shut out the English labouring classes that even then had become famous for the art of colonising-except they would be inclined to take the advice of some astute legal adviser who might advise thus :- "You can easily avoid this proviso by making it appear that you are a Catholic." My legal friends,-and I have many among you-don't be offended at the suggestion, because you know as well as I do that there are some who, if they lived in those days, would not hesitate to make the suggestion.

This act of St. Laurent, although it at first appeared to work well, was not so well conceived as he thought it to be, for it soon had the effect of bringing to this colony a great number of good and bad,the bad predominating-which caused Trinidad to cease, in all but name, to be a Spanish possession. Although colonized by the permission of Spain in the 
manner indicated, it was not truly a Spanish colony, the large majority of its inhabitants being of other nationalities, and these not of the best sort, with the result that the population of the island which in 1783 was under 3,000 in 1797 numbered nearly 18,000. A free grant of land of 32 acres was given to each white man, and half that quantity to each free black man, with half as much again in either case for every slave possessed or brought into the colony. The colonists were to be free of taxation for ten years ; and while they were required to take the oath of allegiance to the King of Spain, they were given the benefit of naturalization after five years' residence."

Before this period the government of the island had long been in a state of confusion amounting almost to chaos, when it was thought expedient to appoint Don José Maria Chacon, a liberalminded governor, to govern the island and carry the decree or " Cedula" into effect. He arrived on the 1st September, 1783-fourteen years before it became a British colony--and on his arrival the "Cedula" was translated into English and French and acted upon. One of the articles limited its benefits to persons professing the Catholic religion ; but the liberality and toleration of Chacon often made this article a dead letter.

The land granted under this law was to be held in perpetuity, ${ }^{*}$ and even down to the present day this

* Known now-a-days as an Old Spanish Grant. 
claim has been set up and recognised in our courts of law as a sufficient title to landed property, by any person who can establish the fact that their family had been in possession of such at the time of this decree.

The portion of Article IV which alluded to the slaves "brought into the colony" was very much abused, because it encouraged that which afterwards became such a constant outrage as to induce the Grenada government to pass a law against it. For instance, a former inhabitant of Grenada who had settled in Trinidad, and decided to engage in this nefarious traffic, had nothing to do but go over there, and, under a friendly pretext, induce former free black or coloured acquaintances to pay him a visit on board his sloop or other kind of ship and then kidnap them, bring them over to Trinidad and declare them to be his slaves. There were no questions asked, so that these unfortunate men who had been, perhaps, the owners of property in their own country, were no sooner landed in Trinidad than they became slaves-an outrage which could not long be tolerated, and met with very strong protests.

From the English West Indian colonies, from Grenada, St. Lucia, and St. Vincent-then French colonies-as well as from the worn-out colonies of Guadeloupe and Martinique and the pestiferous swamps of Cayenne, quite a number of persons were found to take advantage of the generous offer of land and protection; so that in 1784 Trinidad became a French colony in all but name, which to the 
present day has led many people to the erroneous idea that it had at one time been a French possession.

This method of inviting a population to Trinidad had the effect of bringing to its shores a large sprinkling of the disgraceful characters of the West Indies, including many old buccaneers and free-booters, alluded to, who having lost the power of their former wide-spread depredations on the sea, confined themselves to their raids upon the neighbouring islands, and particularly on Grenada, which led that colony to enact a law as follows :-

"And whereas some persons have come from Trinidad, and lurked in these islands for the purpose of seducing and carrying off slaves ; and other persons residing in Trinidad have sent artful negro or mulatto slaves for the like purpose; and it is but just and reasonable to proceed against those who reside on the very spot which holds out a retreat for fraudulent debtors and stealers of slaves, and where no redress or justice can be had." It is therefore enacted........" That all persons coming from Trinidad shall give bond on their arrival in one thousand pounds sterling, to be of good behaviour ; and if such bond is not given, such person to be declared a vagabond, and, without any other proof than that of usual or frequent residence in Trinidad, to be committed to gaol." "*

The misconduct of the residents of Trinidad was one of the reasons for its capture by Sir Ralph Aber.

* Robinson's Life of Picton p. 57 and Vol. III. Laws of Grenada, clause 8, p. 232 . 
cromby. The Cedula also allowed all foreign emigrants to bring with them such black or coloured people as they chose to call their slaves, which often proved to be a serious wrong, for in those days a black or brown complexion was prima facie evidence of a servile condition, and led to many of these people being clandestinely kidnapped on board a sloop or other vessel and conveyed to Trinidad, where all that was necessary was to allege that these unfortunate people were the bona fide property of the kidnapper. Chacon, although it is admitted on all hands that he was a good, conscientious man, was not able to contend against this and like illegal acts.

"If any man could have promoted the success of the extraordinary project of colonizing Trinidad according to the plan of St. Laurent, that man was Don José Maria Chacon. All who speak of him, not excepting his bitter and persevering enemies, admit that he was a man of great talent, indefatigable activity, superior accomplishments and incorruptible integrity.

"He seemed to be one of those rare governors who dedicated all their physical energies to the good of the colonies over which he presided. He was a man of letters, well conversant not only with the rich literature of Spain, but with that of England and France, whose languages he wrote and spoke with considerable proficiency.

"Although a pious Catholic, few men who ever lived were more tolerant to those not in communion with his church than Don Chacon. Amongst the few 
Irish and English new settlers there were some Protestants ; this Chacon knew, yet as far as he could he protected and encouraged them. An English clergyman of the established ehurch was forced by stress of weather to the island. The worthy governor sent for the gentleman, entertained him most hospitably, caused the vessel to be repaired, and, in fact, gave him every assistance he could. He often conversed with him on religious topics, but always in a strain of charity and toleration. He told the clergyman that he had been captured by the English during the last war and the honourable treatment he experienced from that nation caused him to feel gratitude towards England.

"Population now flocked into Trinidad in thousands, and Chacon did all he could to contribute to their comfort and prosperity. We now for the first time read of Surveyors-General, Assessors (legal advisors to the Governor) and Alguacil mayors, (officers resembling high sheriffs in England.)

"A difference now commenced between the handful of old Spanish settlers and the numerous new ones, which should be explained. From the miserable state of the colony formerly, few or no surveyors lived in the island; hence when enormous grants of land were made to the Spaniards they fixed their own boundaries. To men who had neither the means of cultivation nor of selling immense tracts of woodlands, they were nearly uesless; yet people natrually do not like to part with what they inherit, 
or suppose they inherit, from their forefathers, to a set of men whom they conceive are interlopers in the country.

"Again, in order to protect the aborigines, the crown of Spain used to grant to particular families whole districts, in order that they might govern the poor Indians of those districts. The aborigines were fast verging on extinction, and the Spanisin families claimed those lands.

"With the want of surveyors, of records of the extent of land bought, or granted by the crown, whole provinces given for the benefit of the grantees to protect the aborigines, Governor Chacon found the few Spaniards so far in possession of the territory of Trinidad, that he scarcely had any lands to concede to enterprising new settlers which the Cedula invited to the shores of the island. This matter was productive of great inconvenience and some vexatious lawsuits. In many instances the old colonists demanded high prices for their right to the lands, which they alleged with some truth, they enjoyed time out of mind. To remedy this evil, the governor issued a proclamation bearing date the 27th of July, 1785 .

"The preamble of this proclamation, which is rather long, recites all the evils which resulted from the irregular occupancy of crown lands by the ' ancient Spaniards, who, without previous form, concession, admeasurement, or demarkation of boundaries, as had been wisely provided for by the fundamental laws of all nations.' It speaks of the poverty and indolence of 'those same Spaniards' as incapacita- 
ting them from cultivating and giving a real value to the lands. It recites all the inconveniences resulting from such a system, such as causing the whole of the fertile lands to be in the possession of those who could not or would not make them productive ; and the law-suits resulting therefrom."

It then, in eleven clauses, recited the terms on which these lands were to be retained, surrendered or compensated for, and winds up as follows :-

"And that the above articles might be observed and carried into execution in all parts, his Excellency ordered them to be published in the usual place of port, and copies thereof to be fixed up, and others to be sent to the town of St. Joseph de Oruña, valley of Tacarigua, and to all the Commandants of the Quarters that they might publish them in their respective districts, and another copy to be transmitted to His Majesty for his royal approbation. And His Excellency decreed, ordered and signed this act with the advice of his council in Port-of-Spain, whereof I give faith,

Before me:-

JOSE MARIA CHACON.

JOSEPH DAMIEN DE CUENCA.

LEWIS CENTENo, Sec. Fis.

To recount every public act of Don Chacon during the close upon 14 years, that he was governor of Trinidad, would be a task beyond the scope of this work. That he was a just, generous and able governor has already been stated; that he had a difficult task before him in governing the heterogeneous body 
that flooded Trinidad after the scheme inaugurated by St. Laurent is beyond dispute ; that the drastic measures he adopted to restore the land, which had been fraudulently obtained by the old Spanish inhabitants, to the possession of the crown so that it might be equitably divided amongst the new comers - to whom this inducement was held out for them to settle in Trinidad-also met with a good deal of opposition by those who claimed to be the owners. This opposition being based on no better foundation than that they had received it conditional on their efforts to protect and instruct the aborigines-which they in a great measure, failed to do-was the means of causing Don Chacon to publish in the proclamation referring to the land such words as these :-

"As the ambition of many Spaniards is carried to such excess, that they are unable to put a single quarrée* of land in cultivation, they pretend to be proprietors of considerable portions in different quarters, and quitting these, pass over to the crown lands and thereon employ the little labour they are capable of, these persons must likewise make selections within three months of the situation most suitable for their establishment, whether on their pretended property or on crown lands. The surplus land remaining in benefit of his Majesty, as is provided for in the preceding article."

It was further reserved that:- "Whenever this government shall grant crown lands, and anyone shall have cultivated a part thereof, he shall be dis-

* About 31 acres. 
possessed of it under conditions of his being paid the value of the plantations or provisions that may be found thereon, and other expenses he may have incurred on his establishment."

This does not mean, as at first sight it may be inferred to mean, any former holder who had been granted crown lands, but those who unlawfully held possession of crown lands which recently had been granted to the new comers, were to be ejected from it on receiving compensation for the crops, buildings, etc., then found on it.

I may here mention a fact not generally known, that the Proclamation containing these regulations was afterwards, in 1868, taken as the basis on which the Trinidad Government formed the "Squatters Ordinance ; 3 of 1868." A portion of section three reads as follows :-

"It shall be lawful for any Stipendiary Justice if he shall see fit, on making any order under this Ordinance.... to allow as the value of any building or growing crops, or cultivation, on such lands, to such person and such sums shall be paid by the Warden, etc."

Anyway it very considerably alienated the old Spaniards from whom this land had been taken, and it was alleged against Chacon that all this was done in the interest of the newly introduced French inhabitants. Supposing it was, was it not justified as against those who had previously robbed the aborigines of their possessions? Anyway it made his position anything but a comfortable one, and from then 
until the time when Trinidad became a British possession, matters became worse and worse every day, and the efforts which he made to restrain the newly arrived inhabitants, who had become quite overbearing, made many of them conspire to seize the colony. Fortunately before this could be carried into effect Trinidad was captured by the English.

The great Abercromby was a generous enemy, and he treated Chacon and all the inhabitants with due courtesy. He conceded all that Chacon asked for and the conditions set out in the Articles of the Capitulation show how solicitous Chacon was for the future welfare of the inhabitants whose care was henceforth to be in other hands.

Chacon left Trinidad a few days after the Capitulation never to return to it. On his arrival in Spain he was arrested and so remained under arrest till the 28th May of the following year when he and Apodaca* were tried by Court-Martial,-called in Spain a "Council of War :-

"The council unanimously adjudged that Chacon and Apodaca were fully justified in their conduct in the surrender of Trinidad and therefore honourably acquitted them."

Thus ended the trial of Chacon. His enemies were not, however, satisfied and they began intriguing against him ; while the French republicans in Trinidad, who were very numerous, carried it to extremes. They sent emissaries to Paris, when Napoleon was first consul, and at a time when he had great influence

* The Commander of the Spanish Fleet. 
at the court at Madrid. These emissaries represented that France had lost a glorious inheritance by not seizing upon Trinidad for which they had been laying the foundation. Three years after Chacon's honourable acquittal by Court-Martial, the King of Spain was so influenced against him that he ordered his degradation and dismissal from the service and perpetual banishment from Spain. He retired into Portugal where he lived supported by the charity of his friends.

A favourite nephew of his at length returned from long service in the Spanish navy and boldly appealed against the injustice done to his uncle, and with praiseworthy persistence forced his case to the royal notice. At length, after many delays, it was pronounced that Chacon was a much injured man and the victim of base intrigues. His recall from banishment was ordered, but death at an inn prevented him from being able to avail himself of what was designated "the Royal Clemency." He lived long enough however, to have this mandate communicated to him by his faithful nephew, in whose arms he died. Thus ended the career of this eminent màn, long and gratefully remembered by the British inhabitants of Trinidad.

The following summary of a few passages referring to Chacon, from an eminent writer, who was well acquainted with Trinidad and its bygone history will, I trust, be of interest. The name of the writer I shall let the reader find out for himself, as it is 
sometimes good to let one either turn over the stores of his memory or make a search for the source from which the quotations are made.

"No man was bletter pleased than Chacon, -when Spain was no longer able to keep possession of Trinidad that it should pass into the hands of the English, a nation who would govern it with justice and equity. And so his prediction and hopes were fulfilled. It speaks well for the mildness and justice of British rule that, in three generations-at the most - such a community as we now possess should have been able to form itself out of material so discordant. That British rule has been a blessing to Trinidad all honest folk know well.',

Then in another passage speaking personally of the latter days of Chacon he says :-

" Thus ended-as earth's best men have often ended-the good Don José Maria Chacon. His only monument is one after all, aere perinus; namely that most beautiful flowering shrub which bears his name ; Warsewiozia, some call it ; others, Calycophyllum ; but the botanists of the island continue loyally the name Chaconia, to whose blazing crimson spikes, which every Christmas-tide renew throughout the wild forests, of which he would have made a civilized garden, the memory of the last and best of the Spanish Governors.", 


\section{CHAPTER V.}

SIR THOMAS PICTON AS GOVERNOR OF TRINIDAD.

The PICTON OF History.

How incomplete a description of Trinidad Then and Now would be did it not contain an account of Sir Thomas Picton, first Governor of Trinidad under British rule, is obvious to the most casual observer. The subject is complex, as it apparently describes two different men. One a man of the keenest knowledge, wisdom, discretion and exemplary firmness ; a courageous and heroic character ; a good governor and, as described by many, "the best governor Trinidad ever had," who, at a trying time, when the characteristics of a firm ruler were required, displayed the most brilliant qualities in an exceptional way. The other a despot, cruel, even to demoniacal cruelty, haughty, indiscreet, immoral and dishonest ; the bane and curse of the country. My purpose shall therefore be to describe him in each of the two characters set out-The Picton of History and the Picton of Calumny, leaving it to the reader to decide between the two ; but at the same time reserving to myself the right to express my opinion on the whole matter, feeling confident, however, that the unbiased reader will do him justice and that he will emerge unsullied and unstained. 


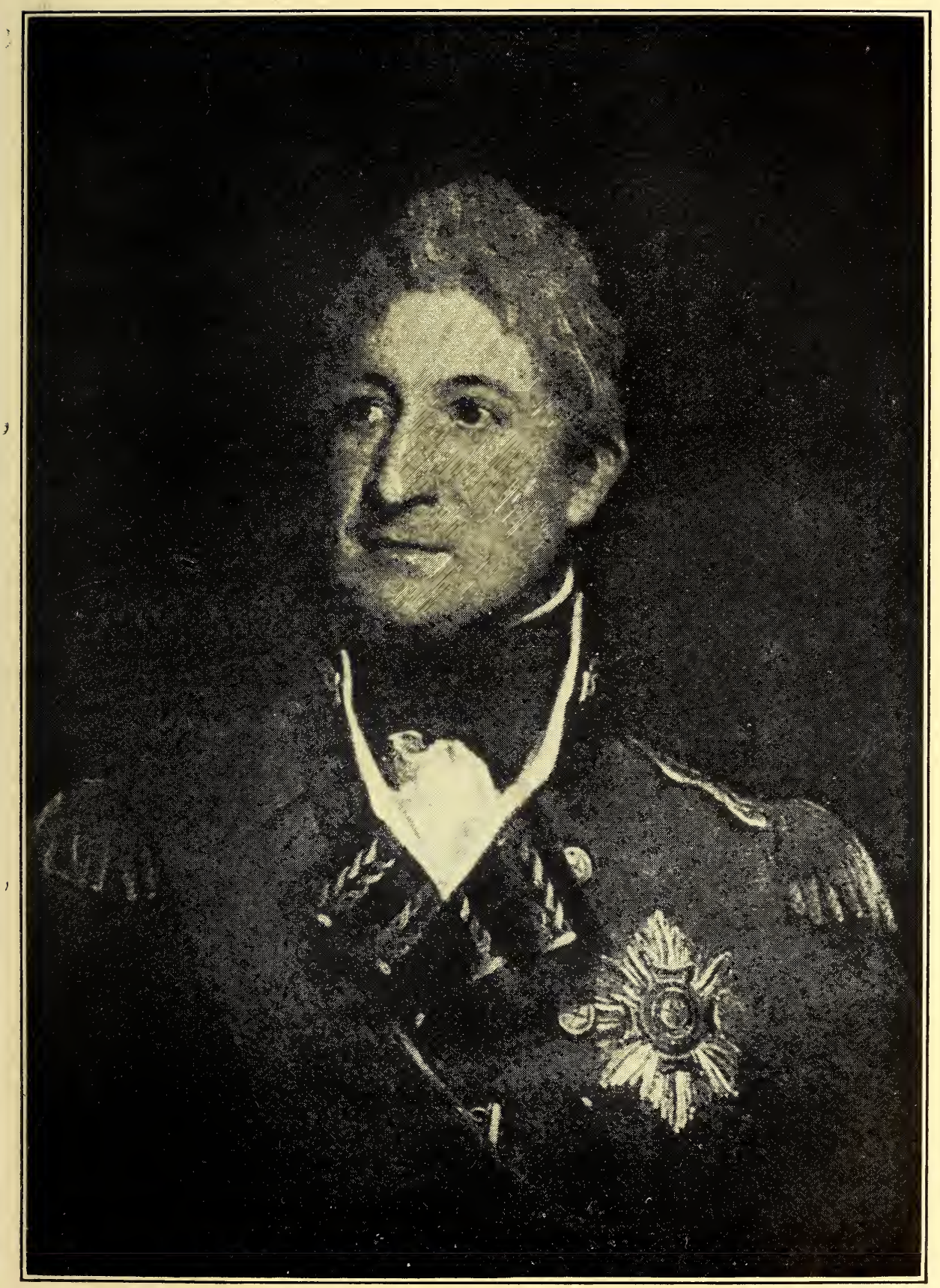

LT.-COL. SIR THOS. PICTON. 

"Look upon this picture-__."

It now becomes my pleasing task to give a slight and necessarily brief account of Trinidad's first British Governor in the person of Sir Thomas Picton. He was the son of Thomas Picton, of Poyston in Pembroke, South Wales, a man of considerable position and wealth-the two things do not always go together -and was born in August 1758, so that at the time of his appointment as governor of Trinidad he was 39 years old-a sufficiently ripe age even for a governor. He was a younger son, and, like most younger sons, had to strike out a way for himself ; but fortunately in his case, he inherited considerable property from his mother, which in after years stood him as a valuable asset in the hour of his need. At an early age he set his heart upon a military career and being specially educated with that object, he entered the academy of Monsieur Lachée to study all branches of a military education. In addition to this he studied Greek, Latin and Roman classics and became a proficient in Euclid. While at Lachée's academy he particularly studied mathematics and the art of war. While yet only thirteen years of age he obtained an ensigncy-a rank not now known in the army-in the 12th Regiment of Foot, then commanded by his uncle, Lieutenant-Colonel William Picton, and in 1777 he was gazetted as Lieutenant in the same regiment. He served for five years in Gibraltar where he acquired a thorough knowledge of Spanish, which probably accounts for his selection in after years by Sir Ralph Abercromby as Trinidad's 
first governor. After this long spell of inactive service in Gibraltar he became tired of garrison duty and sought for more active service. Unfortunately, he was transferred to the 75th Regiment then about to return to England, and thus by a great piece of bad luck missed the active service for which he craved. Within a few months from the time he left Gibraltar, the Spaniards fitted out their grand expedition for the attack of that fortress-the key of the Mediterranean. The 12th Regiment, which Picton had just left, bore a distinguished part in its defence, and it was with feelings of deep regret and keen chagrin that he came to understand the opportunity which he lost. Besides this he had other reasons to regret having left his old regiment, one of which was that for many years he was doomed to the irksome task of mere routine duty in provincial towns.

In 1783 a sudden reduction took place in the military forces of Great Britain, and amongst the regiments disbanded was the 75 th, then stationed at Bristol, where Picton, being the senior officer, was in command. When this regiment heard that they were to be disbanded, they entered into a league that they would not deliver up their arms, and considerable alarm was felt in the town, lest other regiments should also join in the mutiny. Picton hearing of what had occurred hastened to the scene and having singled out the most active of the would-be mutineers, drew his sword, and without a moment's hesitation rushed into the midst of them, seized the ringleader, and dragged him out from the midst of his comrades and 
had him marched to the guard room and confined in the cells. He then spoke to the band of disaffected men and sent them to their barracks where they were quietly deprived of their arms. By this courageous act, which often distinguishes the weak from the strong mind, the danger of a mutiny was averted and the regiment was in due course disbanded, only retaining their ordinary uniform, they having no other clothing.

The matter of the mutiny was reported to the War Office and Captain Picton's courageous conduct became known to the King, who gave orders that his approbation should at once be communicated to Captain Picton for "the courage and true military spirit which he displayed in quelling the mutiny in the 75th Regiment."

When this regiment was disbanded Captain Picton was placed on half pay, which meant that he would be obliged to stroll about doing nothing to serve his country, and for this delightful employment his grateful country accorded him the munificent sum of 5/- per day - the amount of a captain's half pay.

Reader, I wonder if you know what an inactive life means to an active-minded man such as Picton was, ready and willing to work, and work hard, no matter how hard, so that he might be employed. I can sympathise with him, even although I have considerably more than what his half-pay amounted to, for the conviction is strong upon me that no activeminded man wishes to be idle. This I know from 
personal experience, for if I wished to be idle I would not now be writing in an indifferent way the history of an illustrious man dead long before I was born. But to return ; this is an unwarrantable digression. Captain Picton found himself at the age of 25 doomed to lose all the advantages which his early training had gained for him by his early promotion, as he was now obliged to remain for a considerable time on the half-pay list of captains. Fortunately, however, for the honour of the country in which he was destined in after years to play such a distinguished part, he never lost heart, but, on the contrary, determined to prepare himself for any rôle which the exigencies of his country should call upon him to perform ; or to use the words of his biographer, "It was during this long interval of privacy that he laid the foundation of his after fame, and qualified himself to compete for a place among the heroes of his country."

When France, in 1793, commenced that momentous struggle against the nations of Europe, it induced Captain Picton to again seek for employment in the profession he loved so well, but not finding it at home, he embarked for the West Indies where events were then marching fast, having no better prospect than a slight acquaintance with Sir John Vaughan,-from a branch of whose family the celebrated Father Vaughan of London fame is descended -who at once appointed him to the 17th Foot, making him at the same time his confidential aide-decamp. 
Picton was now, for the first time in his career, employed on active service, and Sir John Vaughan was so pleased with him that he quickly promoted him to the rank of Major in the 68th Regiment, in which capacity he also filled the position of Deputy Quarter-Master-General, entitling him to the brevet rank of Lieut.-Colonel. General Vaughan having died in Martinique his temporary successor, General Knox, conferred the post which Picton held of Quarter-Master General, on another, and Picton feeling that an injustice had been done to him, resolved to return home. Before, however, he could put his resolve into execution he was asked by General Leigh-who in the meantime became senior officer on that station-to assist him in receiving Sir Ralph Abercromby, who had been appointed as successor to Sir John Vaughan as Commander-in-Chief in the West Indies.

When Sir Ralph Abercromby arrived in Barbados, Picton was introduced to him, and Sir Ralph having recognised him as the nephew of Colonel Picton-already alluded to-appointed him to his personal staff, offering him plenty of active service in the campaign about to be opened by him against such colonies as still remained in possession of the French. The first place decided upon to be attacked by the English was St. Lucia, and the troops sailed from Carlisle Bay, Barbados, in a fleet commanded by Admiral Sir John Laforey. Having arrived off St. Lucia, Major-General Campbell was ordered to disembark with 1,700 men-Picton being selected to 
accompany him-this he succeeded in doing, and, in due course, St. Lucia was captured, with a total loss of the English, during the short but laborious and glorious siege, of 566 killed, wounded and missing.

Reader, permit me to make a short digression in order to give a sketch of Admiral Sir John Laforey, who, although not so well known to history as Admiral Harvey-who took part in the capture of Trinidad, and some years later received the body of Nelson in his arms, when that hero fell at the battle of Trafalgar-yet he played a conspicuous part in the taking of Grenada, St. Lucia and St. Vincent, then French possessions. His family settled in England at the time of the Revolution. $\mathrm{He}$ was the second son of Colonel John Laforey, Governor of Pendennis Castle. He entered the navy and having attained the rank of Post-Captain in that branch of the service, was appointed in 1772 Commissioner for His Majesty's naval affairs in the Leeward Islands in the West Indies; he was removed in 1784 to Plymouth, where he was constituted Resident Commissioner. He was created a Baronet on the 2nd December, 1789 and obtained the rank of Admiral of the blue in 1795, and sent in command of the West Indian fleet, where he took an active part in the capture of the Islands named.; $\mathrm{He}$ died one year before the taking of Trinidad.

So pleased was Sir Ralph Abercromby with the services rendered by Picton in the capture of the island of St. Lucia, that he issued the following order, "All orders coming through Lieuteuant- 
Colonel Picton shall be considered as the orders of the Commander-in-Chief." No higher trust could have been conferred. After this St. Vincent was attacked and captured with a loss to the English forces of about 180 killed and wounded. In this attack Picton again distinguished himself.

Upon the termination of this short but brilliant campaign, Sir Ralph Abercromby returned to Martinique-then in possession of the English, but afterwards ceded back to France-and from thence returned to England taking Picton with him, who was frequently called "Abercromby's pupil,"-an appellation of which he was indeed justified in being proud.

After a short stay of two months Abercromby returned to the West Indies, accompanied by Picton as his aide-de-camp, and without any incident worthy of remark, arrived at Martinique in January 1797. An expedition against Trinidad, as already detailed, had been for some time determined upon, and, as soon as preparations could be made with Admiral Harvey, the capture of Trinidad was put into execution, and brought to a successful issue. After its capture, and its being ceded by the Spanish governor to the British, Sir Thomas Picton was appointed its first governor.

\section{"The Hour aNd The Man."}

It is admitted on all hands, by all rulers of nations and by the people of all countries, that the British Empire is built up by making the best of the material to be found at hand. Wherever the British 
flag is once unfurled and set flowing free to the freer winds of heaven, it affords the utmost liberty to each individual forming the component parts of the country over which destiny calls it to rule, irrespective of nationality, class or colour. It is, perhaps, this characteristic more than any other, which makes for success in colonising.

In no case was this more truly exemplified than in the conduct of the English Government towards the captured colony of Trinidad. They displaced a tyrannical, illiberal government, who, but for the humanity of its then governor, Don Chacon, would have sacrificed to the Inquisition-whose members had but a short time before been expelled from Trinidad by Chacon-or banished from the land every Englishman not professing the same religion as themselves. And yet what do we find when these Englishmen obtain the upper hand? With that sacred instinct for religious liberty, that feeling that a man's religious belief is a sacred thing between himself and his God, and that almost divine spirit of fair play-which are dominant characteristics of the English governing race-they recognise the inhabitants of this captured country as social equals, and sign a Convention, demonstrating to a people who had long cringed under a tyrannous government, a sample of British equity, which assured to them and other individuals not only religious but civil liberty, as shown in the two following clauses:-

"The free exercise of their religion is allowed to all the inhabitants." 
" The free coloured people shall be protected in their liberty, person and property, like other inhabitants.'"

Observe well, no restriction is placed upon their religious profession; nor is any placed upon their liberty, person or property ; but, on the contrary, free liberty to all. No more kidnapping, and no more sequestration-as was formerly the case-of other persons' property, while the equitable administration of the laws, as they then existed, were to be continued till such times as desirable changes should become necessary. These changes did not take place for many years afterwards, while some still remain the law of this land.

Picton, after having been appointed governor by Sir Ralph Abercromby, wrote thanking him for the appointment and for the confidence thus reposed in him. To this Abercromby replied : "Colonel Picton, if I knew any officer who in my opinion would discharge the duties annexed to the situation better than you, to him would I have given it."

When Picton was appointed, Abercromby wrote a series of instructions indicating the best methods to be adopted by him in governing the island, and mentioning the polyglot, and, in many cases, difficult and discontented class he would have to deal with. He felt himself in a position that might well have intimidated a man of less resolution ; but he, with that energy by which he was distinguished, immediately applied himself to discover the root of the 
existing evil, and the most effective means for its extermination.

Among those who had been recommended to him as intimately acquainted with the internal state of the country, was a certain old gentleman, Don Christoval de Robles, who had for nearly half a century been holding important positions in the government of the colony. To him Picton wrote asking for advice, and de Robles promptly and energetically replied :-

"As you have done me the honour of consulting me, I will give you my honest opinion on the situation of this colony.

"The population is mostly composed of refugees and desperate characters, who have been implicated in the rebellions and massacres of all the neighbouring islands; their principles are incompatible with all regular government, and their inveteracy to your nation is irreconcilable. The timidity of the former government suffered their crimes to pass unpunished; and at your arrival they were actually masters of the island........

"A considerable portion of your troops, if one may draw a conclusion from their conversation and conduct, are not well affected, and may be easily seduced; and those people will leave no means untried to effect it. If you do not give an imposing character to your government before the climate diminishes the number of your soldiers, your situation will become alarming. If those men do not fear 
you, they will despise you ; and you may easily foresee the consequences .........

"There is but one line of conduct by which you can extricate yourself from all these difficulties. The circumstances of the conquest have virtually combined in you the whole power of the government. You are supreme political, criminal, civil, and military judge. You unite in your own person the separate powers of the governor, tribunals, and royal audience of Caracas ; our laws enable you to judge summarily, without recusation or appeal. Circumstances like the present have been foreseen by our lawyers, who have provided remedies equal to the occasion. You are not shackled by forms or modes of prosecution. If you do substantial justice, you are only answerable to God and your conscience."

Such was the advice of a man who had for many years held high offices under the late Spanish government, and that it was justified is fully shown by the action which the Grenada government had to take, (as already shown in the chapter bearing on Chacon) and the instructions issued by Abercromby, (already alluded to, the full text of which can be seen in Robinson's Memoirs of Picton, page 37).

When "the hour " came "the man" was found in the person of Sir Thomas Picton, appointed to be the first British Governor of Trinidad. In the name of its English King, and on behalf of the British nation, and in proof that he ruled well, I quote the following passages from Joseph's History of Trinidad. 
"From this time until the end of the 18th century, all prospered under Picton; the commerce, population and agriculture of the island increased with a rapidity unexampled. The governor showed, by his mental energy and personal activity, that he was endowed with a frame of iron. I am obliged to add, he ruled Trinidad with a rod of iron. The Spanish inhabitants, who now in general became quiet colonists and good subjects, petitioned Picton that if peace was made, Trinidad should not be given up for any equivalent. The governor backed their petition with his own recommendation, and this doubtless was the cause of Trinidad's remaining a British possession at the peace of Amiens."

I regret that want of space prevents me from giving the petition and recommendation; but both can be seen in Robinson's Memoirs of Picton, pages 72-80. Is it therefore any wonder that the large majority of the inhabitants of Trinidad, who but recently owed allegiance to a weak and tyrannical Spanish throne, should so soon become enamoured of a good and just government as to petition Picton to hold on to Trinidad. Picton went further than that, he also recommended that the British government should seize a certain part of Venezuela, then belonging to Spain, as a protection to the commerce of Trinidad in the future. I give a short extract from the despatch relating to this.

"The town of Cumaná is centrally situated, so as easily to communicate with the province of Guayana on the one hand, and that of Caracas on the other, 
with the intermediate towns of Barcelona and Cariaco. The town itself is capable of no defence, being open on all sides, and will probably be evacuated on the first appearance of a force ; at least, such was the determination some months ago.

"If about three thousand troops could be collected with a sixty-four gun ship, a frigate, and some forty-fours or India transports to make an appearance or impression-for a squadron would be not otherwise useful-I would propose immediately taking possession of Cumaná. The public mind has long since been prepared, and the people in general look forward to it as the most favourable event which can befall them."'........

No attention was paid to this, but, of itself, it should be sufficient to show the residents of the present day the wisdom and far-sightedness of Picton. Had his advice been taken, Trinidad would not now have to suffer from the $30 \%$ surtax levied by Venezuela on all imports into that country from Trinidad.

That Picton ruled Trinidad with a firm hand there can be no gainsaying, and that he had no easy task is also beyond dispute, for he was surrounded by a host of spies, among which were some of his own soldiers, who were ready not only to betray him but to deliver his head to either of the governors at Caracas or Guayana, each of whom had offered a reward of twenty thousand dollars for it. 
With regard to these rewards he wrote a characteristic letter to each ; but as they are so much alike, I will only reproduce one :-

\section{" Port-of-Spain, “25th January, 1799.}

"Sir,

"I understand your excellency has done me the honour of valuing my head at twenty thousand dollars. I am sorry it is not in my power to return the compliment. Modesty obliges me to remark that your excellency has far over-rated the trifle ; but, as it has found means to recommend itself to your excellency's attention, if you will give yourself the trouble of coming to take it, it will be much at your service.

"Your excellency's very devoted

" humble servant,

\section{“THOMAS PICTON.}

"The Governor of Guayana."

Picton's personal strength and courage were too well-known : even this tempting offer was not sufficient to induce any of the bad characters, who at the time infested the island, to undertake the desperate task of gaining possession of his head. This offer was probably induced by the fact becoming known to the governors of each of those provinces of his having recommended the capture of a portion of Venezuela.

He remained governor of Trinidad from February 1797 to the latter part of 1802 , when, in conse- 
quence of the change of government in England, it was decided to govern each West Indian colony by commission.

Lord Hobart, Secretary of State for the Colonies, in a letter dated July 9th, 1802, wrote thus to Picton :-

"His Majesty has thought it expedient to place the government of the island in commission ; judging that, from the union of civil, military, and naval talents, combined in the persons selected for this service, advantages must arise which cannot be expected from the labours of any one individual.

"The experience of your conduct from the time the island was first placed under your charge has induced his Majesty to select you as one of the persons to whom this important trust shall be confided."

The Commissioners were : William Fullarton, General Picton and Captain Hood of His Majesty's Navy. Nothing could have been more unwise than the appointment of this Triumvirate. From the first they began to quarrel, Picton maintaining that anything he did before its appointment must remain as his sole indisputable act ; Fullarton asserting otherwise and attempting to upset some of Picton's acts and decisions. At first Hood sided with Fullarton, but eventually, seeing through his dishonest motives, sided with Picton, and thus Picton's acts and decisions before the appointment of the Commission remained in full force. From that time began what is designated in the following chapter, 
The Picton of Calumny.

"- and upon this."

A newspaper writer named M'Callum, by some strange way, seemingly without any design, found his way to the shores of Trinidad, and immediately began to write a series of letters, signed " Vale," addressed to a member of Parliament, which from time to time appeared in the columns of a Liverpool newspaper and eventually. published in book form under the title :-

\section{TRAVELS IN TRINIDAD}

DURING THE MONTHS OF FEBRUARY, MARCH AND APRIL, 1803.

Mr. M'Callum did not lose much time in beginning his calumnious attack on Picton; he begins by dating his ninth letter

$$
\begin{aligned}
& \text { "Head Quarters (?), } \\
& \text { " Puerto de España, } \\
& \text { “' March, } 1803
\end{aligned}
$$

\section{“DEAR SIR,}

"Since the commencement of these letters, I frequently indulged the idea of relinquishing altogether my present pursuits, from the many difficulties with which I am circumvented, and the danger I am exposed to in a colony governed by the Inquisition. If the members of it only knew that my pen is so devoted to the cause of humanity, they would soon torture the hand that holds it; therefore I am obliged to be extremely cautious, lest my enquiries should insinuate suspicion." 
Enquiries ! Enquiries of what? Does this not indicate that he was either sent or brought out to make enquiries about something which he is not manly enough to tell ? There are, however, people who have no hesitation in saying that the person in whose interest he was sent or brought from America was Fullarton, and in pursuit of things connected with the government of Picton. This veracious (I had almost written voracious) author does not leave the reader long in doubt as to his object, he begins by giving a biography of Picton :-

"Thomas Picton, as being the leading character, claims our first attention. He was born of obscure parents, somewhere on the mountains of South Wales I am totally unacquainted with his early progress in life, or his relations, any farther than he has a sister married in New York, to a peddling broker of the name of Bette, who was originally an itinerant showman or player in the United States : at other times a sailor, etc. He came here about two years ago to pay a visit to his brother-in-law, who being elevated, in a most extraordinary manner, to the appellation of 'Excellency' which none of the family ever enjoyed before or since the days of Caractacus. It was some time before little Bette could be recollected in the pomp and grandeur of the great man's court, and even then it was with that coldness, which manifests a treasonable abuse of friendship, and an inward perplexity, the constant companion of pride, with a sort of secret sense of unworthiness that sunk him amidst his triumph and fancied greatness." 
"There are some pitiful wretches, who having just emerged, by a perverse partiality of fortune, from the lowest condition, conceive that the only way of shewing themselves qualified to maintain their new character is to manifest an extreme scorn for their old one ; and that, to evince an elevation of mind proportioned to their rise of fortune, they have only to discard the associates and witnesses of their humble beginnings......... Bette returned (as I am informed) disgusted at the change in his brother-inlaw's deportment, as well as his morals, who mistook pride for dignity, giving himself airs of importance, and behaving to all as if haughtiness were his exclusive prerogative, as though civility belonged only to private men ; yet instead of being respected, he was the reverse."

There is a lot of similar abuse and baseless insinuation, throughout his entire work, yet one reads very many pages before one finds a single substantial allegation charging Picton with any offence that would, in the slightest degree, be degrading to the man he set out to vilify. I will first dispose of this characteristic sketch, and come later to those against this then, and afterwards, famous man.

The writer of the book "Travels in Trinidad" did not know Picton,- the man whom the King of England had chosen to be governor of Trinidad and to whom Abercromby wrote as quoted :- - He says, "I am totally unacquainted with his early progress in life, or with his relations any further, etc." Reader, have you been so "totally unacquainted" 
with an illustrious man's life, and yet able to find out that "he has a sister married to a peddling broker ?" M'Callum could not find out that this illustrious man was the son of Thomas Picton, a man of considerable position in Wales, and the nephew of the Colonel of the 12th Regiment, who had been specially thanked by the King for a great act of bravery, yet, took infinite trouble to find out that he had a sister married to a peddling broker in New York.

Look at the pains this veracious writer took to find out something about Picton's sister (poor woman) and yet not able to say one favourable word about her brother, who was beginning to write his name deep in history.

Were it not that I intend to convict this scurrilous writer from his own writings, which so often cruelly vilify Picton, and that I may be the better able to clear him from his foul aspersions, I would not quote any more of his book. Here is another falsehood which I quote :- " yet instead of being respected he was the reverse." Read what Joseph says on this point.

"It is a fact scarcely known in England, even by Picton's biographer, that he was, with all his faults, the most popular governor that ever ruled in Trinidad since its capitulation; he was truly feared and loved by all ; his enemies, although active were never numerous, and far from popular. I mention this not as proving anything, for men may be popular and unpopular without being good or bad. I merely state the facts." (Joseph, page 283). 
To quote M'Callum again : "The violence of Governor Picton has been very conspicuous on many occasions, but never displayed itself more forcibly than at the close of the late war. The inhabitants of the unfortunate colony had long groaned under the oppressions of their military chief, whose aggressions were only equalled by the patience and moderation which supported them.......... The mild spirit of conciliation, which calmed the agitations of Europe, brought no peace to Trinidad. The cessation of hostilities between our country and France was, in this island, the declaration of war against every British. principle; and the moment which annexed Trinidad to the dominions of our sovereign, decided its unworthy representatve to prevent its enjoying whatever is valuable in British protection."

It is difficult to understand what this vague accusation meant? If it meant the retention of Spanish laws, Picton was not in any way responsible for it ; this was done by order of the King in Council, and so remained for many years after Picton was dead. This untruthful statement must have been made with but one object, that of discrediting him with the British public, who were ignorant of anything relating to Trinidad or its government, and in the sole interest of Fullarton who had just been appointed joint commissioner. As the King's proclamation is not very long I will quote it.

"It is Our Will and Pleasure, that for the present, and until our future pleasure shall be signified therein, the same courts of judicature which subsisted 
in the said Island previous to the surrender thereof to us, shall, for the present, be continued in the exercise of all the judicial powers belonging to them in all criminal and civil cases, and that they shall proceed according to the laws by which the said Island was then governed; and that such judicial powers as, previous to the surrender of the said Island to us, were exercised by the Spanish Governor, shall be exercised by you, our Governor, in like manner as the same were exercised previous to the surrender of the said Island."

Did this not remove all responsibility from Picton in the administration of the laws as they existed, no matter how repugnant, or how contrary to British notions they may have been ? M'Callum then goes on to say :-

"The circumstance of a British governor struggling to prevent the extension of British laws to a British colony is so extraordinary, and so totally repugnant to every principle of freedom, that, I think I shall be excused for dwelling a little on the cause which produced it, and the violent consequences which resulted to the inhabitants (?)...... "He has frequently declared in his correspondence with His Majesty's ministers, that the inhabitants were perfectly satisfied with the existing laws. A contrary declaration from the inhabitants themselves he contemplated with horror."

I have carefully read every word of the petition referred to and fail to find one word of complaint against Picton or his mode of government. I here 
quote a section from it. After the usual preamble of flattering words and fervent prayers, etc., it goes on :- "by extending to your faithful and affectionate subjects in this colony the privileges and protection of the British constitution as experienced by a free representation in a house of Assembly, and in trial by jury : privileges which we inherit in common with our countrymen under your Majesty's mild and benevolent government in Great Britain and its numerous colonies."

It was signed by 114 persons of position among whom we find many of the names of the present day, a few of which I will give :-John Sanderson, M.D., Robert Mitchell, Thomas Law, Townsend Pasea, Alexander Dick, Anthony Wharton, William Dickson, William Readhead, William Gray, etc.

M'Callum states that instead of this petition being forwarded, Picton threatened some of the petitioners and imprisoned others. But for this assertion, he gives his bare word as an authority, and I can find no other in the numerous books which $\mathrm{I}$ have read. He continues his abuse for some pages and at length comes to the real accusations against Picton, giving a long list of them, but the two most import. ant are the hanging of Gallagher, an artillery sergeant on a charge of rape, then a capital crime, without trial. This was deliberately untrue; he having been tried and sentenced by court-martial, and I don't think it formed one of the charges made against him in England. The other was that of Luisa Calderon. 
Of Gallagher's case Joseph says :- "I have carefully read over this man's trial by court-martial and must say, if ever offence of that abominable nature were clearly proved, and unless three witnesses committed the most deliberate perjury, he died a guilty man." (page 289).

The other case is that of Luisa Calderon. It is one of a different nature and on account of the amount of excitement which it created-not in Trinidad, where it was recognised as legal, but in England -requires the most delicate reasoning as to its merits or demerits; and in order to do so the whole case must be set out.

Luisa Calderon was a young coloured girl over 15 years of age,-although, in order to bring Picton in guilty of a crime, it was alleged that she was not 14, at which age it would not have been lawful to apply what was, in Spanish law, called the "question," which I will describe in due course. She lived with Pedro Ruiz in the double capacity of house-keeper and mistress. Not satisfied with this connection she struck up an intimate acquaintance with a married man named Carlos Gonzalez, and on a day when her master, Ruiz, was absent, assisted her more favoured lover, Gonzalez, to rob Ruiz of a large sum of money. On the return of her master, he, requiring a part of this money, found that it had all disappeared. Enquiries were made and it was ascertained that Gonzalez had been seen in the house with Luisa Calderon, and further enquiries revealed the fact of her closer intimacy with him. An effort was 
made to get her to confess her share in the transaction, but she persistently denied all knowledge of or participation in it. This being so the magistrate (assessor) who had charge of investigating the case reported to Picton, and advised him to apply the "question" to compel her to acknowledge her complicity with Gonzalez and disclose where the money was concealed.

I quote the official communication sent by the Notary to Picton in full, as it would not be fair to give only a resumé of it.

"December the 23rd, 1801.

" In consequence of the strong suspicion his honour entertains of the mulatto, Luisa Calderon, a domestic of Pedro Ruiz, concealing the truth relative to the aforesaid robbery expressed in these proceedings, and his honour being persuaded that she will discover the truth of the matter by means of a slight torture inflicted on the said Calderon ; and whereas his honour is not invested with power to execute the same his excellency the governor and captain-general of this island must be made acquainted hereof, with the summary of this process, by virtue of this document, to the intent that his excellency may determine as may appear to him justice. The usual and requisite forms to be adopted and observed by the notary in the cause, and in pursuance hereof his honour thus decreed and ordered; and he signed hereto, which I the under-written notary attest this day, the 22nd of the aforesaid month and year.

"Before me, FRANCISCO DE CASTRO, "(Signed) BEGORRAT." 
Upon this representation, Picton made himself acquainted with the usual proceedings, according to the laws of the island and calling upon the notary to word the sentence, the notary wrote and Picton signed :-

"Apply the question to Luisa Calderon.

"TH. PICTON."

The "question" was applied in a private room. At first she was resolute in her determination to be silent, but after a little time she acknowledged that she had submitted to the wishes of Carlos Gonzalez, and that it was he who had stolen the money from the house of Ruiz, and Gonzalez subsequently admitted that he had been intimate with Luisa Calderon for about four months and that he visited her on the day of the robbery. This class of offence was at this time a capital one and Gonzalez might have been sentenced to be hanged, but this extreme penalty Picton did not inflict; he sentenced Gonzalez to pay one thousand eight hundred dollars, to work upon the roads till the fine should be paid, and then to be banished from the island. Luisa Calderon was set at liberty.

This will form a suitable place at which to describe how this species of torture was applied. Two pieces of wood, having a flat iron plate one and a half inches square on the top, was fixed into the receptacle made to receive it, then the victim's arms being tied to her sides, a leather belt was passed around her body, and she was lifted off her feet by a rope over a pulley attached to the ceiling till her toes rested on 
the top of the square flat pieces of iron on the top of the wood, until she should confess her guilt or otherwise. Such was the mode of applying the "question" as provided for by law.

It is no more a part of my duty to defend this cruel practise, than it would be to defend the brutal practise, were it now the law, of flogging a man condemned to be hanged before executing him ; but if it were the law-no matter how repugnant-it would have to be sanctioned by the governor of the colony, or by the Secretary of State, and carried into effect by the proper officer entrusted with the duty. To say that such a thing would not now be tolerated may be true, but it is beside the question. Then was not Now, and many cruel things were done Then that would not be tolerated Now. "Applying the question" in all such cases was the law, and that Picton was so advised by his responsible legal adviser, is beyond doubt; if he had hesitated to apply it on account of the sex of Luisa Calderon other improper motives might, and no doubt would, have been alleged against him.

It was alleged that the torture on Luisa Calderon was inflicted with great severity ; that she fell down unconscious; that no doctor was present to revive her ; yet the truth was, that but little pain was inflicted, the confession was almost immediate, that the girl was so little affected that she walked with a cigar in her mouth, from the gaol, more than half a mile, to the scene of the robbery, where she pointed out the manner in which it had been effected. There 
was a surgeon present at the picketing; there was no necessity for one then or afterwards, as the feet were not swollen or injured.

The frequent disagreements between the commissioners caused Picton to resign, but at the request of the General commanding the troops at Barbados, he accepted, for a short time, the appointment of governor of Tobago.

On his return to England serious charges were preferred against him, the case of torturing Luisa Calderon being the principal. He was tried, and on two false statements - that Luisa Calderon was under 14 years of age, and that the Spanish law relative to applying the "question" was not the law in Trinidad-he was convicted. He, however, appealed against this decision, and asked for a new trial and, the case being referred to the Privy Council, he was granted it.

In the meantime no device was left untried to enlist public sympathy; Luisa Calderon was even taken over to England. She was a good looking coloured girl, of a specimen rarely seen in London in those days, and she was constantly driven about the streets and parks of London in an open carriage with Mrs. Fullarton ; and with the desired effect of inflaming the public mind against Picton.

On the 11th June, this new trial came before Lord Ellenborough and a special jury, when the evidence was again gone through at greater lengtb, and Mr. Dallas proved beyond doubt that the law of old Spain, which is the law of Castile, was in force in 
Trinidad at the time of its capitulation; and the Vicar-General Alvarado certified that he had baptised Luisa Calderon on the 6th of September, 1786, thus proving that she was over 15 at the time of applying the "question." The trial was further postponed and a commission appointed to take evidence in Trinidad. Among the many written questions for witnesses to answer was this one :- "Did you know General Picton, and what was his general character ?"

To this question there was an unanimous answer by fifteen prominent inhabitants of Trinidad, many of whose descendants have occupied positions of great trust and wealth. Among them being Chevalier de Gannes, a proprietor for ten years ; Chevalier de la Sauvagere, formerly governor of Tobago ; Don Francisco de Farfan, a planter ; Baron Montelambert, who stated "I came to the island to settle in consequence of the honourable report of his character made to me by the Duke of Portland and the Right Honourable H. Douglas ; " Don Hilario Begorrat, ordinary judge, (whom it will be remembered signed the certificate for Picton to fill up relative to applying the "question" to Luisa) ; John Lynch, a proprietor for twelve years; the Honourable John Nihell ; the Honourable Philip Langton, and others whose descendants I cannot now trace in Trinidad, although, doubtless, if I mentioned them, they would be recognised.

I will give two specimens of the replies. Chevalier de Gannes said :-_I knew him intimately. 
When I arrived in this colony, there were a number of very bad subjects in it, and it was threatened with a general subversion of good order. Brigadier-General Picton restored good order, maintained the police, protected commerce and the importation of provisions, and tripled the value of land in cultivation. I have known him to be extremely just towards all the inhabitants of the colony, without any prejudice to any of the various foreigners."

The Hon. Philip Langton said :- "I had the honour of being intimately acquainted with General Picton; and all the respectable characters, that I ever heard speak of him in the colony, join me in considering him an active, intelligent, humane, and disinterested magistrate, warmly attached to the interests of his sovereign and of this colony."

Mr. M'Callum, what does your ghostly spirit say to this Were you not aware of it when you wrote your letter dated 12th December, 1804 to Mr. Joseph Marryat-to be found in the preface of your bookwhen he, of his good nature, threatened to take an action against the newspaper that was at that time publishing your articles or letters, on Picton, and yet your vindictive nature would not allow you to retract. I wonder if Mr. Langton included Mr. Fullarton and Mr. M'Callum in the phrase in his reply " all respectable characters, etc" !

The verdict delivered at the second trial is rather curious. It found that torturing was legal at the time in Trinidad, and absolving the defendant of malice against Luisa Calderon "independent of the 
illegality of the act." Picton was neither fully convicted nor acquitted; he was released from bail but judgment was never delivered.

Fullarton, the merciless calumniator of the dauntless Picton, did not live to see the close of his relentless prosecution-or persecution, was it ?having died of pneumonia on 13th February, 1808, while the object of his great animosity lived to be acclaimed a few years later one of the glorious heroes of world-famed Waterloo.

So much for Mr. M'Callum and his accusations. Picton's name and fame remain an everlasting monument to his memory and his country, while Fullarton's and M'Callum's names are scarcely known even to a few, and here I might leave the controversy, as an eminent writer advised, "between these two writers-M'Callum and Robinson whom I have quoted-leaving the public to judge for themselves."

Picton was nearly sacrificed to the emotional philanthropy that accepts an overcoloured story as gospel, and is ready to condemn a public servant too hastily, on imperfect grounds. England's difficulties at the time required his services. Wellington specially applied for them and he cheerfully responded to the call and as subsequent events in his life, and in the history of his country proved, with such success as to reflect glory upon his name and his country.

It is no part of this short sketch of Picton's life to follow him through " the battles, sieges fortunes," that he "passed through" in the Peninsular war; suffice it to say that he and his "fighting third," com- 
posed chiefly of Irish soldiers, saved the day for the English arms on many a hard fought field culminating in the battle of Waterloo. This division was always conspicuous during that protracted war for "its daring enterprise and indefatigable activity." After the battle of Ciuda Rodrigo, Wellington wrote to Lord Liverpool, "General Picton has inspired a confidence in the army, and exhibited an example of science and bravery which has been surpassed by no other officer."

That he was also beloved by his soldiersalthough he sometimes used hard words to them-is evidenced by the fact that on an occasion when their chief returned to duty from England-where he had been on leave-they left their encampment and went more than a mile to meet him with cries of "here comes our brave old father, three cheers for old Picton."

As I set out to tell the story, and it is not yet fully told, have patience, therefore, and hear a few words more from men who are in no way mixed up in the squabble between Fullarton and Picton. The first is an encomium passed upon him by General Gascoyne in the House of Commons on the night of 29th June, 1815 , eleven days after his death. Speaking of the battle of Quatre-Bras,-in which engagement Picton distinguished himself, at the same time receiving what later proved a mortal wound-and of his glorious death at Waterloo, he said :-

...... " His body was not only blackened by it, but even swelled to a considerable degree : those 
who had seen it wondered that he should have been able to take part in the duties of the field. He fell gloriously at the head of his division, maintaining a position which, if it had not been kept, would have altered the fate of the day, and its issue might have been different from that which now occasioned such well found rejoicings." Many people think that the words " might have been different" ought to read "would have been different."

He was killed at the battle of Waterloo and the brave soldier, whom a rancorous spirit had maligned in early life, was greatly honoured after death. He had a splendid funeral, a noble monument-to which the king contributed $£ 100$-was erected in his native county, and at the unveiling of it General Sir Christopher Cole said :-

"But, gentlemen, it has happened to me in the performance of my professional duties, many years ago, whilst serving in a distant quarter of the globe, to be called under the notice of that distinguished character, when he held a situation of high trust and responsibility as governor of one of the West Indian islands ; and I had frequent opportunities of witnessing the activity, ability, and rigid principle, which marked his conduct in his high situation : and I left the Island of Trinidad with impressions of respect and admiration which time can never efface."

And then he goes on to touch on the accusations made against Picton and his final trial and then continues :- 
"It is known that the fall of this hero was accomplished by a desperate and new example in military tactics and that, at the head of a body of infantry he attacked at the point of the bayonet, and defeated, what had been until that day considered the finest cavalry of Europe ; and no British heart can do otherwise than give the meed to his memory, of having devoted himself to death for the glory and safety of his country."

And yet this is the man accused of brutality. I have had, in my day, a good deal to do with and observe men of all classes and all conditions, and I assert that $I$ have never known a brave man a bully or a tyrant-strict, yes ; but a tryant, never-and that Picton was a brave man is a fact beyond dispute. But neither have I known a bully or a tyrant who was not also a mean sycophant and an arrant coward.

Among the host of heroes of all ranks, from the little buglers who sounded " the advance" or "the charge," to the generals who headed or directed their brigades or divisions, throughout the whole of the Peninsular or European wars of that time there was no braver or greater hero than Picton, Trinidad's first British Governor, a man who most assuredly laid the foundation of what has become to-day a bright gem in the crown of him who is now our sovereign. 


\section{CHAPTER VI.}

THE AUTHOR'S ADVENT' TO TRINIDAD.

Having paved the way, in a manner which I hope has not been unacceptable to my readers, for that which is to follow as a synopsis of, and observations on, my personal experience in Trinidad, I shall now begin by setting them out in such a manner as will enable me to contrast the Trinidad of Then with the Trinidad of Now, and, I trust, also the Trinidad of the Future. I shall endeavour to show a good deal of its progress, prosperity and prospects-although the latter " lies hidden in the lap of the gods," or perhaps, to use a less poetic and more literal expression, in the bowels of the earth, in the material known as oil, in which it is confidently predicted, Trinidad has a great future.

It must not be presumed that from the day of my advent to, or my arrival in, what I may without flattery call this beautiful and prosperous island, I began to set down every thing in the order in which I might at some future day describe it. It was not so, for I had not the most remote intention of writing this or any other book. As the greater part of the events which it is now my intention to write about are mainly culled from the stores of my memory, I 


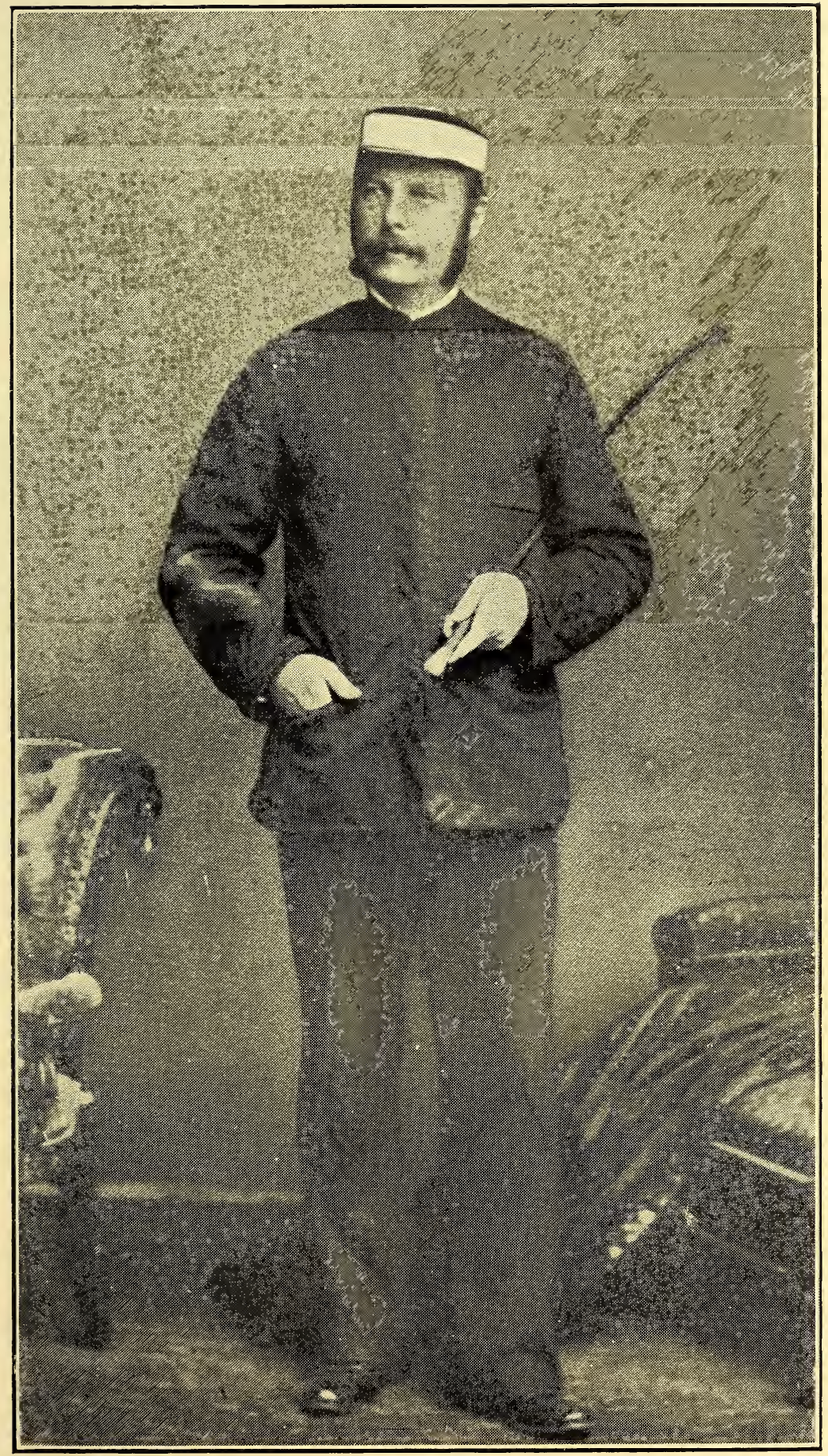

THE AUTHOR "THEN," 

trust that any little defects which people of equal or greater knowledge may discover will be overlooked by them.

I must state at the outset that I have had the good fortune always to have possessed a good memory. It has continued to the present day, and has served, to a remarkable extent, in helping me in my professional capacity in the various grades in the police force through which I have passed. As an illustration of this faculty I will give two illustrations as a selection from many : one when I was a school-boy and the other many years after my arrival in this colony.

The Trench family, or at least a branch of it, has been so long settled in Ireland as to be recognised as Irish. The celebrated Archbishop Trench, a member of that old and ancient family, was, at the time I write of, theological professor at King's College, London ; he became, some years afterwards, Archbishop of Dublin. In the early fifties of the last century he was on a visit to his relatives near the village of Clane in Kildare. One Sunday, sometime in the late summer or early autumn, he preached in the parish church of Clane, at which my school attended. He was an eloquent preacher-or so he appeared to me-but he had a peculiar intonation in reading. The first lesson of the day was taken from the first chapter of Isaiah, and his text was also selected from the same chapter, as follows: "The ox knoweth his owner, and the ass his master's crib : but Israel doth not know, my people doth not consider." In reading the lesson 
the peculiarity of his voice attracted my attention, and I was keenly on the look out for the sermon. I followed it closely, not, I am ashamed to say, with any decided intention to be the better for hearing it, but that I might be able on the morrow both to repeat it to my school-fellows and also to imitate his manner of delivery. To my delight I found that I had mastered both, and on our way home from church gave frequent passages from it to the delight of my hearers, and, for many years after, I was able to repeat most of it ; even now-sixty years after the event-I think if I made an effort I could repeat a good deal of it.

That Archbishop Trench was in his day a very celebrated divine is well known; he is also the author of many standard works.* One of his christian names was peculiar-at least so it appeared to me and others at the time. We don't hear the name Chenavix every day, and its peculiarity so struck us that we at once abbreviated it into " China."

On the following day Mr. Trench came with the rector of the parish to visit our school. As these gentlemen appeared, the master went out to meet them, and as they remained outside for some time I exclaimed, "Look, boys, there goes Old China ; now for his sermon." I at once began, to the great enjoyment of the other boys, and having proceeded for some time, with my back to the door, I was soon aware, by the expression on the boys' faces, that something was wrong. On turning round, to my great horror, I saw the master, the rector and Mr. Trench standing in the

\footnotetext{
"And of the poem "Harmosan,"
} 
doorway. The master at once ordered me to my seat and began to apologise. Mr. 'Trench, with good humour beaming on his face said, "Let the lad alone. I want to hear him," and calling me to him said, "What have you been reciting ?" " Only trying my memory, sir, by repeating your sermon of yesterday," I replied. "Let me hear you," said Mr. Trench, " and begin at the beginning; I want to hear you. Don't be either bashful or timid; I am fond of recitations !"

Don't think that, sir," said the master, "if he begins he'll go through with it.' And so I began. As I proceeded, a spirit of mischief crept over me and I not only repeated the sermon but mimicked the preacher's voice and mannerisms. The master was making signs to me but to no effect ; the spirit of mischief was aroused and I heeded him not but continued through to the very end. When I had finished, Mr. Trench called me to him and said, "I see that your memory is superb and your mimicry not bad," and turning to the rector and master he said, "this is the most extraordinary thing I have ever seen or heard ; he has, so far as I can remember it, repeated my discourse of yesterday word for word," and putting his hand into his pocket gave me two half-crown pieces. Of course, out of my sudden wealth, I had to stand a small treat to the other boys

In the course of the same week he was telling the incident to some ladies, amongst whom was my godmother, and mentioned the name of the boy who, as he designated it, had the wonderful memory. My 
god-mother, hearing the incident, was so pleased with it that she soon came over to see me and congratulated me on my attention to religious instruction ; and, on leaving, gave me a half sovereign. We were again in funds! Poor lady, had she but known the motive for being so attentive it is very probable that I would not have got her generous tip.

The other illustration which I will give occurred the year after my arrival in Trinidad. I will make the details very short. I was a witness in a case in which the importance of my evidence played the chief part. Before going into the witness box I spoke to the Attorney-General-Mr. (afterwards Sir Henry) Ludlow-and said, " Let me give my evidence without, as is usual, asking me questions, as I can always tell what I have to say better in this way. To this he willingly agreed.

I entered the witness box, and proceeded to give my evidence slowly, watching the pen of the Chief Justice, Sir Joseph Needham, so as not to outrun him. I saw the Attorney-General follow the copy of my evidence as written on his brief, and when, having finished, I came down from the witness-box, addressing me he said, "When did you read the notes of your depositions?" I replied "I never keep notes of my depositions, I can always carry them in my head where they cannot be seen or read." "I can see," replied Ludlow " the covering is pretty thick;-(he evidently did not refer to my hair which even then was not thick) - but, joking apart, it is extraordinary ! Do you know you 
have repeated your evidence as it is written on my brief ? You have not changed a word! I think, in fact I am sure, there is not another man in the court who could do it."

I give these two illustrations, not for the purpose of in any way extolling myself, but that they may serve as a guarantee of the correctness of the sketches which will follow. Memory is a gift, and a very valuable one ; it can, it is true, be cultivated. I have never tried to do so ; to me it is natural.

Since it became known that I was writing a book many people have said, "We hope you will give us something spicy." I again repeat what I have said in the introductory chapter, that I will not offend the living by going too closely into the sins of the dead. I am therefore of opinion that those who rely upon anything "spicy" will be disappointed. Except in a few instances where the facts are now only known to myself, and where the identity of the other actors who have passed away will not be indicated, I will adhere to this resolve. But if they are desirous of reading "spicy things" of the Trinidad of the past I refer them to M'Callum's "Travels in Trinidad" and Captain Hodgson's "Truths from the West Indies," both of which are referred to in this work but not largely quoted. If what they read there does satisfy them I will not supplement it. That the morals of Trinidad have very much improved since Then must be Now apparent to every one. I think 
that to-day we are neither better nor worse than other people.

"He who woula love his fellow men

Must not expect too much of them."

This is bad rhyme but good common sense.

It may with truth be said that there is not much in the foregoing relative to my advent to Trinidad. True ! but there must always be a preliminary canter before the real beginning ; this is simply my preliminary canter ; its significance will occasionally appear.

In the month of September, 1874, I and four other members of the Royal Irish Constabulary were appointed to various posts in the Trinidad Police, for the purpose of, as it was alleged, reorganising (?) it. (The number of times it has since been re-organised (?) is almost past count.) I think, however, that to reform not only it but Trinidad in general would have been the more appropriate term. However, of this more anon. It so happened that I had a good friend in the Recorder of Belfast at that time, and one day meeting him I told him that I was " going to Trinidad." " Trinidad!" he exclaimed, "let me see, I think a friend of mine is at present governor of that place, if so I will give you a letter of introduction to him. Call and see me in a few days, say Friday, I am going to London to-morrow but I will be back next Wednesday evening." I consequently called, and he said, "Yes, Mr. Cairns is at present governor but I understand he is about to resign ; I will write to his brother, Sir Hugh, about it." Sir Hugh was the familiar name by which Earl 
Cairns was then known, he having been for many years member of parliament for Belfast, but at the time my friend, the recorder, spoke to me he was in reality Viscount Garmoyle and Lord Chancellor -afterwards Earl Cairns. I called on the day appointed, and was shewn a letter which my friend had received from the Lord Chancellor, in which occurred these significant words : "My brother is at present goveruor of Trinidad but he is about to resign; the task of cleaning the Augean stable there was too much for him, I strongly advise your friend not to go there. I enclose you my brother's address, and it will be better if you write personally to him." My friend did so and showed me the reply he received, from which I took extracts that were a guide to me in my early career in Trinidad. The letter contained a good deal more than what will be foreshadowed. That, however, as Kipling says, " is another story."

At the time of my appointment I had served sixteen years in the Royal Irish Constabulary, and a special training which $I$ had for three or four years undergone in that force-besides having passed through two huge riots in Belfast-in a great degree specially fitted me for what I had soon to undergo in Trinidad. My fellow colonists,-- for I am now one of you-don't be offended if I say at this point that the crimes in Trinidad in those days surpassed anything I had ever dreamt of ; but this also in its due course, I have at present to tell of our voyage out.

On our voyage we had as fellow passengers a few prominent men, recently, or shortly to be, con- 
nected with Trinidad. Mr. Lovesy, a former Stipendiary Justice of the Peace of Port-of-Spain, but then Judge of the Supreme Court of British Guiana. Captain the Honourable John Bell-Smyth, a pompous, good-natured Irishman, and member of the Legislative Council of the colony and also co-partner in the then prominent firm of Ambard \& Son. Mr. Paul Giuseppi, already alluded to, at that time owner of Valsayn and New Worles sugar plantations (now owned by the Trinidad Government and converted into a horse, mule and cattle-breeding farm, and lately into an agricultural experiment station.) Captain Jackson, private secretary to Mr. (afterwards Sir) Henry Irving (not the celebrated actor) but recently appointed Governor of Trinidad through the resignation of Mr. Cairns-soon to take up the reins of government. And let me here pause to say the best governor Trinidad ever had in my day : I make no exception. (Captain Jackson afterwards became governor of Trinidad, under the title of Sir Henry Moore Jackson. His administration was too short to prove his worth, although he gave good promise, but unfortunately he was cut off by death before he had time to do more than outline his future policy.) Dr. Knox, who had just completed his medical studies, and the Rev. W. Williams, Baptist Missionary in charge of the mission in the southern portion of the island. I mention all these for with the exception of Dr. Knox, they played a more or less prominent part in my life in Trinidad. 
I had many long interviews with Mr. Lovesy, then on his way to Demerara-the familiar name of British Guiana-and obtained much useful information and advice from him which was of great service to me in my career in Trinidad. I afterwards learned that he had been an able Police magistrate in Trinidad and a good friend to the police. I never met him again, but in proof that he was appreciated by the police, and that he equally appreciated them, I will again refer to him and publish the address which he made in reply to one which was presented by them before he left the colony. I can vouch for its accuracy, as it is from the original handed to me by Mr. Lovesy, during one of his numerous friendly chats with me on our voyage out. It has remained in my possession for close upon 38 years. It is not dated, but I believe it was written towards the end of 1873. It will in due course speak for itself.

Owing to the unpreparedness of the Nile for the outward voyage, a much smaller vessel, the Tasmania had to be substituted. The consequence was that many second class cabins were handed over to first class passengers. Amongst the second class passengers were three married ladies, one accompanied by her husband, the others going out to join their respective husbands in one of the South American Republics. These three ladies, in consequence of the crowded state of the ship, had one cabin allotted to them. One lady was a Russian, who, although she could speak French, German, Spanish and, of course her native language, had a very imperfect knowledge 
of English. She had a splendid figure, refined manneis, was well educated, a good musician and had a sweet voice. Owing to these accomplishments her society was much sought after, and she frequently. sang and played at the concerts given on board.

One moonlight night she and her two lady companions were promenading the deck when an individual, who posed as a gentleman, having, perhaps, inbibed more than was good for him, accosted her and made certain improper proposals to her which, when, she came to understand, she indignantly resented, and in her broken English complained to a group of us who were sitting together. She was not long in having the satisfaction of seeing her insulter get his deserts, which he did not, during the remainder of the voyage--or perhaps up to the present day, if he is still alive-forget. He ran away, and meeting Mr. Smyth complained of the frightful treatment he had received from those "wild Trishmen, your countrymen." This caused a great commotion; and here Mr. Smyth comes into the story. He had, previous to this, learned from us that we were coming ont to the. Trinidad police, and in his good natured way had promised to look after us ; but on this occasion, forgetting himself and probably thinking he could bully us,-as I afterwards learned he was in the habit of bullying the police of this colony, - he strode up and demanded to know "where is the blackguard that has assaulted my friend ?" One of the five stepped forward and thus accosted him :- "Mr. Smyth, I am one of those whom you designate 'blackguards ;' I think the term 
would be better applied to your friend; and as 'birds of a feather'-you know the adage-you can also apply the natural inference to yourself. It may be well for you to remember that you are running a great risk of undergoing the same treatment as your friend ; go and join him and console him." Mr. Smyth began to bluster even worse than before, and a crowd having gathered, amongst them the Captain of the Tasmania, who at once desired to know what it was all about. As one of my party was about to explain, the husband of the married lady to whom I have alluded, told the captain the whole story. Mr. Smyth frequently tried to interfere, but the captain, in that quiet way which captains of ships have, said to him "You have nothing to say to this. I will deal with it," and turning to us said, "Gentlemen, I thank you in the name of the insulted lady ; I thank you in the name of all my lady passengers ; I thank you in the name of my owners; and I also thank you in my own name ; " and continuing said with a smile "should anything of the sort occur again, which is not, I think, likely, you may leave it to me to settle." We bowed our acknowledgement and there the matter apparently ended; except that during the remainder of the voyage we were looked upon at times with admiration and at other times with fear, or perhaps a little mixture of both. I don't think however, that we in any way suffered by it.

The next day Mr. Lovesy called me to sit beside him and having complimented us said, "You and 
your comrades are the sort of men required in Trinidad, but if Mr. Smyth is resentful you will have one enemy the more, and an influential one against you." I don't think Mr. Smyth bore any of the others any. grudge for the episode; on the contrary, I believe when he calmed down he appreciated the act as typical of his countrymen. He never alluded to it to any of us, but I believe when he reached Trinidad, one day ahead of us, he spoke of it in the Club but not to our disparagement. Anyway he for a long time was not as friendly with me as he often was with the others.

I know that sometime afterwards he successfully fought the battle of one of my comrades, when an injustice was about to be done him. I would like to relate the incident, but as it would, even at this present day, be a serious reflection on the conduct of a man then holding a highly responsible position, and again stir up a subject that is better left untouched; I refrain from giving the particulars, especially as I was-in a remote way-concerned in the after results, and years afterwards, more directly benefitted. I have, however, to render this meed of praise to Captain the Honourable John Bell-Smyth that some years afterwards and so long as he remained in the colony he was a good friend to me.

When we arrived at Barbados we parted with our gay Lothario. He may have gone on to Jamaica, he may have landed at Barbados, he may have gone to the Northern Islands, or he may have gone to Demerara ; but anyhow from the day of the incident 
we never laid eyes on him. He, was too much afraid of the "wild Irishmen," as he called us, to desire to see any more of us.

At Barbados we transhipped to the old paddle steamer Tyne, then nearly fit for the scrap heap ; the passengers for St. Lucia, St. Vincent and Grenada travelled by the same vessel. She had been, and still was, a very comfortable, steady ship. She required to be very steady, for it will scarcely be believed when I assert that in many places above water-mark she was like a sieve; you could see daylight through her plates. I know it will be trespassing on the credulity of my readers to ask them to believe that I could and did shove my finger through one of the plates.

A different class of ship soon replaced the Tyne and her like on these routes ; the $E s k$, the $E d e n$ and the Solent replaced them and did service between the islands for many years. They have also been later replaced by a more superior and up-to-date kind in the Berbice and the Balantia-quite up to all modern requirements-and passengers who tranship to them for Demerara, and the other places of their route find themselves quite as comfortable as on the ocean boats.

This inter-colonial service forms an amazing contrast to that which existed in my early days : a contrast which reflects the greatest credit on the march of progress made by the Royal Mail Company in catering for the comfort of their passengers. It also serves to illustrate the great strides made in the prosperity of Trinidad when now it can afford to contri- 
bute $£ 18,000$ per annum to this company for the privilege of making it its head-quarters in the West

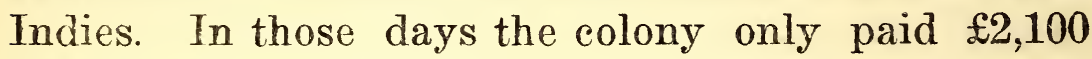
for carrying its mails.

Our trip down the islands was devoid of incident except as we came to St. Lucia, St. Vincent and Gremade we parted with many friends which we had made on board the ocean boat and who were not afraid of the "Wild Irishmen" whom they met for the first and probably the last time. Captain Jackson transhipped on his way to Antigua, only to arrive in Trinidad six weeks later as private secretary to Mr. (afterwards Sir) Henry Irving who then arrived to assume the reins of government in this colony.

I may here remark that in after years when Sir Henry Moore Jackson became our governor, I frequently contrasted the methods of his administration with those of Mr. Irving and so apparent did the similarity appear to me, that I occasionally remarked it to people who knew them when they were both together here. It may be that Sir Henry Jackson being so long connected with Mr. Irving, had either unconsciously or designedly adopted his methods ; or it may have been the other way, that when private secretary to Mr. Irving he was able to, and did, assist in outlining his policy. I would not, now that they are no longer with us, like to take away the credit from whichever most deserve it, so I will leave it to their separate admirers to decide for themselves ; it may have been either or both. They were both 
clever men; but it is only reasonable to expect that the younger learned from the elder.

Some time after our arrival in Trinidad we received a letter from the husband of the Russian lady, to whom I have alluded, thanking us for the care we had taken of his wife.

I landed in Trinidad after dark on Monday the 1st of November, 1874, where I and my comrades were received with a kind of wonder which we did not then understand, but with which we were later made acquainted. And here the remainder of my sketches will begin and end by describing events purely belonging to Trinidad. 


\section{CHAPTER VII.}

OUR OPEN-SPACES.*

In the previous chapter I mentioned that we landed in Port-of-Spain after dark on the evening of the 1st November, 1874. Here I drop my comrades, except when they necessarily make their appearance in connection with other events relating to Trinidad Then and $N o w$, and describe things coming within my personal knowledge and observation ; not for a moment meaning to imply that each in his own way did not successfully play his part, but the exigencies of the service necessitated our separation.

The Police Head-Quarters and Police Court were at that time situated in Frederick Street, in the block of buildings the southern portion of which is now occupied by the Telephone Company's Offices. On the morning after our arrival I was introduced to him who then ruled the destinies of the Police Force. Let me here render him this meed by saying, that he was by far the cleverest man under whom I have served in Trinidad; and with proper training, and other important qualifications necessary to police-

* This chapter was written in April 1912, and was in type in May. The Port-of-Spain Gazette, by a strange coincidence, in their issue of the 23rd June, 1912-which shows that it is possible for two people to think alike-writes of Brunswick Square in a similar strain. 
men, of whatever rank, would have made an ideal Chief of Police. As he in no other way enters into these sketches, I here officially take leave of him, retaining nothing but the kindest feelings in memory of him.

My first duty was the formation of a detective branch to the Police Force,-no small task with the material at my disposal ; but time, in this as in other things, remedies all defects. I was also entrusted with the task of forming the town into a proper beat system ; but of this anon.

Before fully accomplishing these tasks, I thought it advisable to have a careful look around the town and its surroundings, so as to make myself acquainted with all their bearings; for experience had taught me that this is even more important than a knowledge of men and manners, although it must occupy the second place; and it is in consequence of these ramblings at this early date, that things seen for the first time made the deep impression on my memory, and which enables me to write at this distant day the subject that forms this chapter.

My office, which overlooked Brunswick Square and its surroundings, caused it to be one of the first objects that attracted my attention, and I often wondered why it was then in such a wretched condition.

This square, if properly laid out, and properly kept would have been a credit to any town or city in the United Kingdom. I could not help admiring its situation, fine proportions, and stately trees, all combining to form a health-giving lung to the centre of 
the town ; but it also, if properly kept, would have been a beauty-spot to be admired by residents and visitors of all classes. But oh, such order was it kept in! It was a disgrace to this fine tropical town ; and instead of being something for its residents to boast of, and its visitors to be delighted with, was practically an eyesore.

At the time of which I write it was under the control of the Borough Council; -in later years abolished by order of Mr. Joseph Chamberlain, when Secretary of State for the Colonies, during the time when Sir Hubert Jerningham was governor. This body was succeeded by the Town Commissioners and later merged into The Town Board, which designation the "City Fathers" now bear.

My dearly beloved Fathers, I will not for one moment hesitate to say that Brunswick Square was Then a disgrace to the Borough Council, and is Now a disgrace to you. It is true, it is somewhat better Now than Then. You are doing something by slow degrees to bring every part of it up to a level, but I hope you don't mind " a captious critic" saying that you might use more earth and less stones in the process ; it still requires a great deal more than what you are doing and undoubtedly would be the better of a few flower beds and ornamental shrubs. You have done a good deal to improve the footpaths, particularly those used by the busy citizens on their way to business, but you have left the nice circular promenade, that could be beneficially used by less busy and delicate citizens, as a nice, quiet, shady 
walk, neglected, and it is Now in as bad a state as it was Then, little better than a sugar plantation road, sometimes full of ruts and at all times rough and uneven and unfit to be used by invalids or the aged public.

When I was a stranger to Trinidad's supineness I frequently wondered how it came to pass that this fine square came into existence, and so wondering, also wondered how it came to be placed in the position it now occupies, and being so placed how it came to be so neglected?

The answer came to me as a surprise in the following way :-A friend, hearing that I was writing a book on Trinidad Then and Now, lent me a book called "Truths from the West Indies," written by a Captain Studholme Hodgson of Her Majesty's 19th Regiment of Foot, stationed in Trinidad between 1833-8. Writing of Sir Ralph Woodford, who had been governor of Trinidad from the 14th June, 1813 to 1st April, 1828, and particularly of his liberality towards the citizens of Port-of-Spain by bestowing upon them this fine square, he says :-

"A strong instance of this liberal feeling occurred in Trinidad during the administration of Sir Ralph Woodford. His Excellency at considerable expense to himself, caused a square to be built in the centre of the town, a boon of no little value, as until then there was no public promenade in the colony. While the work was in progress nothing could equal the encomiums lavished upon Sir Ralph ; his public spirit and munificence were the discourse of all. 
"The square being completed, a day was fixed for its being thrown open to the public ; but who can describe the surprise and dismay of the colonists, when they learnt that by the word public, was intended all classes of the community, whether of white or black complexion. The governor was now regarded as a rash and dangerous innovator ; and, it was judged requisite to represent to him that this new regulation, if persisted in would do incalculable harm.

He, however, refused to rescind the order, smiling at the silly prejudices which he hoped to remove by his example. He daily frequented the square ; a band was in attendance; every inducement was offered but in vain and these efforts were followed by outrages. For many nights large portions of the iron railings were torn up; the rare and valuable shrubs collected with such trouble from so many parts of the globe were scattered about the streets. At length, however, the conspirators were detected, and, in due course punished."

For many years thereafter no further attempt to ornament or beautify this splendid square was made, except when in 1866, Mr. Gregor Turnbull, of the old firm of Turnbull, Stewart \& Co., presented the fountain which now ornaments the centre of the square ; sometimes full of clear crystal water, sometimes not.

I think that for many years the erection of this fountain was the sole attempt to ornament or improve this square ; anyway, in my early days it was sadly 
neglected, occasionally used as a dumping ground for rubbish, a grazing ground for goats, a scratching and feeding ground for fowls and a play ground for dogs. The railings, at no time the best, became broken and dilapidated; active or lazy men wishing to save themselves a few extra yards walking, scorned the idea of entering or leaving it by any of the nine gates which open into it, but simply climbed or vaulted over the railings. The old Borough Council, a short time before its demise, replaced these railings in 1892 by a substantial, ornamental one, at a cost of $£ 1,52016 \quad 8$, which, besides setting it off, makes the goats and lazy men pay more respect, as they can no longer enter where and when they like. Very little more is required to make this fine square a real beauty spot; it does not require the art of a highly paid or efficient engineer to do it, an agricultural (or shall I call him botanical) labourer with nice taste, and a few East Indian labourers, commonly called coolies, are all that is necessary.

The square is surrounded on each of its four sides, except the east, with fairly handsome buildings. I will begin-in the way one is taught at school to tell off the points of a map. On the north side are the spacious Town Board buildings, built in the old Spanish days, and after a Spanish design; the fine Public Library, erected in 1901, and four private dwelling houses.

On the south stands the fine Protestant Cathedral, called Trinity Cathedral, because, I believe, it was consecrated on a Trinity Sunday. The founda- 
tion was laid by Sir Ralph Woodford on the 30th May, 1816 and consecrated on Trinity Sunday, May the 25th, 1823. A sharp shock of earthquake on the 20th September, 1825, which was felt all over the island, injured the spire of this Cathedral to such an extent, that it had to be taken down, and a wooden frame covered with lead erected in its place. The church is large and has a very fine roof. During the episcopate of Bishop Hayes a beautiful chancel and cloister was added which is a great improvement to the interior aspect of this sacred edifice. One of the best features of the Cathedral is that it stands fairly back from the surrounding streets except on the north. Its appearance would have been greatly improved if it had been erected a little further to the south; but I dare say the designer had his reasons for placing it as it is.

On the south-western corner of Brunswick Square stands a fine commodious Fire Brigade station which is a credit to the town. It was, however, erected solely at the cost of the government instead of, as it ought to have been, by the Municipal authority then in power. It is well equipped, and, I believe, has a competent commandant; but I am afraid that if ever a serious fire again occurs, it will run the risk of proving the truth of the old saying "Too many cooks spoil the broth."

On the eastern side is the unpretentious Greyfriars Presbyterian Church established in 1836 and enlarged in 1877 and alongside it a spacious hall used for many purposes. The remainder of this side is 
occupied by various mercantile establishments, built without any pretensions to architectural beauty, unless we except the English Pharmacy at the corner of Prince Street.

And last, though by no means least, on the western side stands a beautiful block of buildings called "The Red House," in which are located the principal government offices, including those of the Governor, Colonial Secretary, Council Chamber-a very handsome hall-the Court Houses, Judges' Chambers, and various offices connected with the administration of the law, and many other important offices, as the advertisements say, "too numerous to mention."

There were, and still are, two other large openspaces within the town proper,-not including Victoria Square which is but of recent date, and will be alluded to in its proper place,-which were till recently neglected, and now, in conjunction with Brunswick Square, do not receive the attention they require and deserve.

Of these I shall deal first with "Marine Square." Why "square," it is difficult to say ; unless it struck the namer that it was neither round nor oval, or, perhaps his knowledge limited him to the word "square" or " round." It is, however, an oblong, or rather a series of oblongs, about a quarter of a mile long by thirty yards wide, intersected by eight streets running parallel; with a fine broad footway, recently laid in concrete, and a number of smaller ones, radiating in each of the seven oblongs 
like the chief points of a mariner's compass. To this extent has this open-space been greatly improved of recent years.

Here many trees were planted, the greater part of which I think were mahogany ; these in course of time attained fine dimensions, but unfortunately, like the insurance companies doing business in Portof-Spain, they have, from time to time, suffered much from a series of serious fires. Marine Square, like the other open-spaces was also at one time the grazing ground for goats, and a dumping ground for the rotten onions and potatoes of merchants doing business on the south side, as well as of those who traded in the streets running off it, particularly what was then known as Almond Walk. These merchants, with that generosity for which they are proverbial, not wishing to exclusively inhale and derive the sole benefit from the highly aromatic scent rising from this source were often so unselfish as to share it with the general public. To such an extent was this at one time carried on, that many letters written against the practice appeared in the local papers, one of which I remember, purported to be written by a Chinaman-who had the bad taste not to appreciate the scent and signed himself "A. Kow" ; but, by whoever written, the letter was so sarcastic that the Borough Council was moved to take steps to remedy the evil, by passing a set of bye-laws-many of which were ultra vires-but which had the desired effect ; and goats, rubbish, rotten onions and potatoes disappeared and "Marine Square" was put into a 
better state. It might have been still further improved by planting ornamental shrubs and flower beds ; cutting down the wounded trees, which will never recover from the effects of the fires-the result of either cupidity or accident, whichever it may have been. We must, however, be satisfied that something is being done which tends to make it better Now than it was Then.

At the eastern end of this fine open-space stands the Catholic Cathedral of the Immaculate Conception; a description of which I take the liberty of copying from Collens' Year Book, as follows :

"The Cathedral of the Immaculate Conception, a Gothic edifice in Marine Square, was finished in 1832, and like the Anglican one, owes its existence to Sir Ralph Woodford. In it are four chapels dedicated to the Sacred Heart, the Blessed Virgin, St. Joseph and St. Dominic. There are several fine statues and pictures, as also a mural tablet by Chantrey in memory of the founder, Sir Ralph Woodford. Spacious sanctuary. The altar, Communion Rails and Font are of Florentine statutary marble." The two towers originally built of stone, were on the 20th September, 1825 injured by a shock of earthquake and rebuilt, as they are at present, of wood.

During Archbishop Flood's life it was enclosed by a fine iron railing, and the ground thus enclosed was transformed by the planting of flowers and ornamental shrubs, adding much to its imposing appearance. 
Some years ago, not very long since, a fine fountain stood in the wide esplanade forming the junction of Frederick and King Streets, Marine Square and Almond Walk, (the latter now unfortunately known as Broadway); but, like many other careless acts, the Borough Council allowed an act of vandalism to be perpetrated; why, it is difficult for the untutored mind to understand. They permitted the Mule Tramway Company to remove it in order that their line might run direct through the spot it occupied. Surely there was room enough to make them run a loop line around it, and, by a further condition, compel them to erect a nice iron column about thirty feet high with branches to contain bracket lamps. I may be told that the Borough Council had no power to order them to do it, be it so, yet they had power to withhold their consent unless it was done in a way acceptable to them. Every civic institution takes pride in beautifying their chief city, but it would seem as if the old Borough Council took pride in defacing theirs. However, as I have said, better times are making their appearance.

Going northwards we come to Harris Square, so called in honour of Lord Harris who seems to have been much liked in Trinidad. Till recently it too, like Brunswick Square, was sadly neglected, until a Borough Councillor, who lives on the south side, forced the hands of the council by offering to erect a statue to Lord Harris if they would enclose the square; in due course both were accomplished. It is now surrounded by a very handsome railing, 
and has four unkempt gravel paths running from each of the four corners in the shape of a St. Andrew's cross. It is a nice little square-about one fourth the size of Brunswick Square-and would not take much to beautify it. Many complaints are made as to the state of its footpaths. The buildings surrounding it are ordinary dwelling-houses ; it is a nice quiet place to live near and should be healthy.

There are other open-spaces that might be dealt with but space will not permit it. Passing through the Prince's Building enclosure of which, should space permit, something may be said later, we come to the fine Queen's Park Savannah-mention of which is made in one of the chapters on Casual Wanderings. Passing through this beautiful savannah the equal of which few cities in the United Kingdom, except Dublin, possesses, we reach the Botanic Gardens which ought to form a fit adjunct to the residence of the representative of our sovereign, but which till lately were, for many years other than they should be. I am informed that our present governor observing this, sought for the reason, and being told that they were sacrificed to what was designated the more urgent necessities of the agricultural departments, did not see why it should be so and ordered that they should be restored to their former condition. If this be so, then Sir George Le Hunte has earned the everlasting thanks of those who take an interest in these beautiful gardens, for beautiful they once were and can be made so again. 
These gardens were first laid out probably by Sir Ralph Woodford,-at least during his time, and placed under the control of Mr. David Lockhart in the beginning of 1820 , and are spoken of as being very beautiful and scientifically kept. I recently called upon the oldest representative of the mercantile community amongst us, to certify an incident of which I was in doubt, and having obtained the desired information he said, "Why don't you write something about the disgraceful way in which our squares and the Botanic Gardens are now being kept. I was in the gardens a few Sundays back, and I was shocked at their appearance. Oh, what will I say when I remember my old friend Davey Lockhart." I assured him that the article on which I was then engaged was one dealing with this subject, which pleased him very much, and he spent some time in describing their former appearance as compared with now. I told him that an effort was being made to improve them, and he was very much pleased to hear it. That they were well looked after is evidenced by the fact that down to the year 1882 they were a credit to the colony.

I am told, and I believe it to be true, that there are rare plants and trees to be found almost neglected in this, at one time, enchanting spot, described by Kingsley and others "as a joy for ever ;" "a sight once seen never to be forgotten;" "a never ending source of interest and enjoyment." There is a rare plant, the Amherstia, which has never been seen growing wild, and the original plant from 
which it, and all others of its species now growing have been propagated, was found flowering in a Burmah temple during the Viceroyalty of Lord Amherst, from whom it receives its name. It is extremely difficult to propagate in any way, while only in very exceptional situations, such as the hot damp gully in Trinidad gardens, can it be induced to flower. Here for the first time in the West Indies have its blossoms been seen.

But let me ask the present generation in Trinidad-with the exception of what Sir George Le Hunte is now doing to restore it to its former state,-what part has it taken to improve what has been left to us by Sir Ralph Woodford, by Lockhart, or by Prestoe? I hope someone will be able to answer, for I can't. Surely the public voice if raised would be heard.

I am aware that in this age of progress the majority of people are more interested in making two pods of cocoa grow where only one grew before ; and thirty tons of sugar cane, where they were formerly only able to grow twenty ; and so on in progresive quantities with other produce.

I assure you, my fellow colonists, that I would be delighted to see four cocoa pods grow where you ask only for two, or forty tons of canes instead of twenty ; but I certainly would not like to devote my whole time, energy and health, as some of you are doing, in this sole contemplation. Is such a consideration, however intoxicating its prospects may be, a justification for neglecting to cultivate, or assist 
others in cultivating, the beautiful, and so improving our beauty spots? Tourists-and they ought to be encouraged-who come to visit our country and enjoy its climate do not come simply to see two pods of cocoa grow where only one formerly grew, but they come to appreciate and enjoy our suuny, healthy, genial climate; new and ever varying scenery ; our curious fruits and produce; our rare flowers and plants ; the glory of their bloom ; the great diversity of their colour and the hitherto undreamt of beauty of all combined.

But instead of this natural expectation being fulfilled when they come they see our beauty-spots-or what might have been our beauty-spots, if attended to -neglected, and made the home of goats and the patient donkey-no matter how picturesque they may appear in their surroundings-lying under the shade of rare trees and shrubs, or at least rare to the visitor, and for which the wealthy portion of them would willingly give a small fortune to have growing in such luxuriance in the grounds surrounding their homes.

If these visitors miss seeing the things which they expect to see, and find our squares kept in this disgraceful condition, they will go away and compare us to Goths or Ostro-Goths, untamed tribes of whom they read in their school days, who descended in hordes on the fair spots of Europe, devastating all before them. If they have to compare you to these or something worse, they will turn their backs upon 
you with disgust and always speak and think of you with contempt, and of your town with ridicule.

If, however, you on the contrary make your beauty-spots attractive to the eye and agreeable to taste of natural curiosity, you will do much to please them. Let me furnish an illustration. There is nothing "the stranger at our gates" observes with greater curiosity than a cocoa tree, with its numerous furrowed pods,- -hidden under a rough exterior the luscious beans from which their refreshing cup of cocoa or their sweet chocolates are made-actually growing from the trunk of the tree down even to the ground, instead of, as their apples and other fruits do, from the branches.

Personally I know that they look upon a cocoa tree as a great curiosity, and many who cannot afford the time to go to the cocoa plantations, would deem it a treat to see it growing in our open-spaces. When these visitors, tourists, "strangers at our gates," "globe-trotters" -call them what you will -once come to understand that your desire is to please them by catering to their natural tastes, they will classify you, as you deserve to be classified, among the go-ahead civilized nations of the earth. 


\section{CHAPTER VIII.}

\section{INHABITANTS.}

One of the first things that a stranger arriving in any foreign country will think of contemplating is its inhabitants. This must be particularly so in a West Indian colony where, if he has any knowledge of history, he must not expect to find any of the descendants of the ancient stock of aborigines, but instead a people composed of many nationalities and mixed races; and in no place is this more so than in Trinidad. This being so I was anxious to see and study the people of various races with whom I was likely to come in contact in this colony, designed to be my future home.

I think every European or American stranger risiting Trinidad must be struck by the fine appearance of its inhabitants, both male and female, no matter of what nationality, race or colour, and there is a great variety of the three. This was one of the first things to attract my attention, perhaps on account of the marked contrast it offered to people occupying similar positions and of similar education, as those of the manufacturing town which I had just left.

There, and in Great Britain in general, you see, especially in the winter season, either a set of cower- 
ing shivering men and sometimes women, standing at street corners, loitering round grog-shops or hurrying along as if for dear life trying to keep warm ; their better-to-do fellow citizens so muffled up to protect themselves from cold, as to render it difficult to distinguish their features, but here in this land of eternal summer, although there were loiterers, there was no shivering gaunt appearance about them. Sometimes, it is true, scant of clothing, but enough for decency sake and a spirit of good humour, which, although I was partly prepared to expect, from what I had been told and read, was yet somewhat of a surprise.

On this point Kingsley, who a few years prior to my arrival, left England to escape the rigour of an English winter, and, passing a few months in Trinidad wrote :--

"Next the stranger will remark, here as at Grenada, that every one he passes looks strong, healthy and well-fed. One meets few or none of those figures and faces, small, scrofulous, squinny, and haggard, which disgrace the so-called civilization of a British city. No where in Port-of-Spain will you see such human beings as in certain streets of London, Liverpool, or Glasgow. Everyone, plainly can live and thrive if they choose ; and very pleasant it is to know that."

I can bear out this eminent writer's statement in every respect as it also appeared to me, five years after what I have quoted above was written, and for many years afterwards; but of late years this has 
begun to change considerably and I would Now be glad to say what he said Then, " every one, plainly can live and thrive if they choose."

It is not, I am sorry to say, Now as it was Then. There is at the present time a greater amount of apparent poverty, and I am afraid some not apparent, than when Kingsley was the guest of the governor and had the opportunity of seeing the then accessible part of Trinidad; because I assure you there is more poverty in our midst than one might think. Not that Trinidad has begun to deteriorate, for the contrary is the case ; although, like other West Indian islands, it has passed through bad days-happily now tided over-this poverty has therefore to be accounted for in other ways, and I endeavour to account for it as follows :-

On at least half a dozen occasions, within my time, one or more of the neighbouring islands have suffered from terrible calamities ; for instance a water-spout which bursting on Mount Misery in St. Kitts nearly devastated the prosperous little town of Basseterre, or at least the poorer part of it, and caused the poor people who suffered,-not field labourers that would have been welcome, but tradesmen of an inferior sort and town loafers, who were not wanted,- to flow in upon us in undesirable numbers.

Other islands, large and small, lying near to us have suffered in like manner from hurricanes and earthquakes which this colony has providentially escaped, but, in the manner I have described relative 
to St. Kitts, had to bear the after effects. Thus the destitute, and in some cases, almost starving population of those places, had to seek some land in which to live, and hearing that Trinidad, like Egypt of old, had abundance and to spare came down to visit us.

Here the vast majority and their descendants have remained and like the Israelites in Egypt were fruitful and increased abundantly with the effect that what was Then enough for two is not Now enough for four. Thus Trinidad has become a veritable dumping ground for the surplus poor of the neighbouring islands and not being of the required sort became a burden on all.

But, irrespective of this, it is natural that many undesirables from the smaller islands will find themselves, in Trinidad, and that, irrespective of any calamities in their own colony. Thickly populated Barbados presents us freely, also, with some of the scum of its population, for it is reasonable to think that good agricultural labourers should hardly care to leave their native land and that planters naturally make efforts to retain them.

Let it not be thought that by any of these remarks I intend to belittle all the people who come to us from neighbouring islands, for I do not. Many -and perhaps the majority-are not only desirable but welcome ; our police force is largely composed of them and excellent men many of them have been and are. Of this fact no man in this colony can speak with greater authority than I can and it gives me a pleasure to assert it. But this does not justify the 
criminal, loafing classes being dumped down upon us and if Ordinance No. 186, called the "Infirm Paupers Ordinance," were properly enforced it would prevent them from coming. Many years ago I called attention to this, and then a spasmodic effort was made to enforce it but was soon allowed to drop again. I again assert that it is not enforced in the way it ought to be.

There was a story told in my early days, for the accuracy of which I cannot vouch, although it was told to me as a veritable fact which I repeat as I remember it.

Some years ago, it was more frequently remarked upon than it is now that a class of West Indians who found their way here were not desirable. Enquiries being made it was ascertained that at least one of the neighbouring islands adopted a system of getting rid of their criminal classes which, so far as they were concerned, proved effectual. Whenever an old offender was convicted of an offence for which he, in addition to imprisonment, was liable to receive corporal punishment, the magistrate who tried the case sentenced him to be imprisoned for a certain time and in addition to undergo corporal punishment by the infliction of thirty lashes : ten to be inflicted at the expiration of the first month, ten on the day before the sentence expired, and ten within one month after being released from gaol. It is hardly necessary to say that the last ten would have been illegal, but anyway there never was any neces- 
sity for it to be tested, for the offender never came up to receive them and his country "knew him no more." As for this story se non e vero, e ben trovato.

There is also another cause for this poverty, although it is observable in a lesser degree, that of deporting - I think deporting is the proper wordfrom India under the indentured labour system many who were unsuitable as labourers, and being unable to perform the class of work for which they were introduced soon became an unwelcome burden on the planters and in course of time on the colony in general. Hence, from the causes named, one sees more beggars wandering about Now than Then

Having alluded to the poverty amongst us, and endeavouring to account for its cause, I will now return to other matters of a more pleasing nature.

Leaving Port-of-Spain and visiting country districts the first thing that struck me after my arrival, was the apparent poverty of the labouring classes. I have used the word apparent in the visual sense only, for when I came, in a very short time, to see things in their matter-of-fact aspect, I found that what I had taken as resembling poverty, mainly from the scantiness, untidiness, and want of cleanliness of the clothing worn by the workers, was not in reality an indication of poverty. The scantiness and untidiness of the clothes they were wearing was suitable to the climate and their employment.

I soon saw them on Sundays, market days, and holidays decked out in at least some of their finery. 
Before wandering away from Sunday let me quote another short passage from Kingsley. Describing Princestown church he says :-

"We went to church-a large, airy, clean, wooden one-.........A crowded congregation it was, clean, gay, respectable, and respectful, and spoke well both for the people and for their clergyman. But-happily not till the end of the sermonI became aware, just in front of me, of a row of smartest Paris bonnets, net lace shawls, brocades, and satins, fit for duchesses ; and as the centre of each blaze of finery - ' offam non faciem,' as old Ammianus Marcellius has it-the unmistakeable visage of a Chinese woman." ......" All that could be told was, that the richer Chinese take delight in thus bedizening their wives on high days and holidays; not with tawdry cheap finery, but with things really expensive and worth what they cost, especially the silks and brocades."

Kingsley's description mainly referred to the few Chinese hearers who, on that day formed part of his congregation, but mine includes the whole community irrespective of class or colour, and thus I continue. But above all, when attending a wedding or a "christening" Solomon in all his glory was not arrayed like one of them. Then again at the more sober funeral, one sees the women in either their pure white frocks, simply picked out by a black sash or belt and their hats with drooping plumes of black ostrich feathers ; the men in their well made black frock coats, silk hats, and, don't let me forget, their 
nicely folded silk umbrellas, or silver mounted canes. Seeing this in a country place I wondered, were these the people I saw but a few days back toiling in the field, then offering but a slight contrast to the ground they were so industriously tilling, and being answered in the affirmative, I was obliged to feel that they too in conjunction with their town brothers and sisters were equally content.

Let me now, as if in a dissolving view, show the fairer sex in a more distinct shape separating them from " mere man." Where will you see finer figures or women of more stately carriage than you frequently come across in Port-of-Spain or other towns or villages in the colony, as they glide along unconscious of their gracefulness-and therein lies the charm. With what freedom and dignity of motion do they carry themselves even in the performance of their duties, of the simplest kind ; a gracefulness and freedom of action that many "a lady of high degree " might and would, if they saw it, envy. But when they appear at a ball, even the "dignity" of the humbler classes, one is reminded of the sublime passage about the arraying of the lilies of the field.

In a previous chapter I have stated that Mr. Irving came here as governor about six weeks after my arrival. As was the eustom on the arrival of a new governor, preparations were made to royally receive him and celebrate the event by a public ball. This was naturally looked forward to with keen and delightful expectation. I therefore waited to see the youth and beauty of the whole island 
gathered in one place where contrasts could be more easily seen and gauged; I must confess that the reality was an agreeable surprise, far surpassing my expectations.

I do not think there was a single person in that vast assembly, however narrow-minded, hypercritical, sarcastic or ill-natured he may have been, unless he was an old curmudgeon grudging the costly attire of the ladies before him, counting its cost and the rate of interest at which he might have been able to lend the money with which it was purchased-and there are, I believe, a few of that breed, though happily not many-who could help admiring the fine and graceful figures, mangificent deportment, beauty, complexion and unconscious dignity of the ladies, and the tall, athletic, healthy appearance of the men, who lent a charm to the ball that night.

In Great Britain, on the continents of Europe and America, in the larger and more important colonies, among the offsprings of Great Britain's sons and daughters this deportment is cultivated, but in Trinidad and all the West Indies it is natural.

I have often heard people go into raptures over the stately carriage of an humble maid, and the highest descriptive art at their command has been, " she carries herself like a duchess, etc,"-why a duchess in particular, I could never make out-but I have never seen any duchess who could compare in either form or feature with many of the ladies I saw that night, they were magnificent and compared favourably with any I had ever seen before. Some 
might have been compared to the rose of Sharon, others to the graceful lily of the valley.

I have mentioned in one of the chapters preceding this that when $I$ determined to write these sketches I resolved to consult every book I could lay hands on that would give me some information of the Trinidad of the past, and in order to procure them I did everything except steal. In this search I came across an old book which had been rescued from destruction, worm eaten, the cover torn off, and some of its pages missing ; amongst the missing ones the title page and the name of the author ; but on reading it I was able to find the title and the year of publication. From it I give an extract of a letter written in Trinidad 85 years ago. The title of the book is "Four years" residence in the West Indies," the letter is evidently from the pen of a military man and although written in a humorous strain, truthfully, I think sets out the feelings of the writer ; it reads as follows :-

$$
\begin{aligned}
& \text { Lentrer of Major W- } \\
& \text { “Trinidad, 4th May, } 1827 .
\end{aligned}
$$

Dear Bayley,

I am about to keep my promise, in telling you something of Trinidad......... When I describe a beautiful place, I always begin with the most beautiful things in it. These you will easily guess are the women : and of a truth the women of Trinidad are most superb creatures. ...... I have been charmed with the fair Parisians, over head and ears in love 
with the fair Castilians, and over head and ears in debt with the fair English : but here we have French, English and Spanish all in one ; so that I am charmed, and in love, and in debt, and no chance of getting out of it ; a pretty predicament for an officer in the West Indies..... There is also a good society and a fair display of beauty in the ball room. All creoles love dress, but I think the creoles of Trinidad are more tasty than others, etc."

The letter then branches off to describe Port-ofSpain and compares it to its great advantage with the other West Indian towns with which the writer had become acquainted.

If this was true Then, how much more true is it Now that education and other auxiliaries to refinement have done so much to improve society in general. These could not, I am glad to say, have improved the better class without also improving those who move in more humble circles. Might not the letter I have quoted been written yesterday? What struck the writer 85 years ago struck me 47 years later, and will, I am sure, equally strike the visitor of to-morrow. Education has, of course, caused a great improvement in a number of ways, but except for this I don't think the Trinidad of Then was much behind the Trinidad of Now.

It may be asked why is this so evident to everyone who has the pleasure of being present at a ball, entertainment, or other social function in Trinidad ? I think the answer can, to a great extent, be found in part of the letter quoted, " but here we have French, 
English and Spanish all in one." $\mathrm{He}$ might with equal truth-if writing to-day-have mentioned other nationalities as well; the blending of other strong types have done much to improve the creoles of Trinidad.

Reader, have you ever read the letters of "A Citizen of the World ?" I believe the author to have been Goldsmith, but they purport to be written by a Chinese savant visiting England, describing various things coming under his notice. In one of these letters describing the old English aristocracy, he bewails the decline of the old stock through want of the admixture of a strain of more wholesome blood, and strongly advises them to descend from their high pedestal, and by a judicious admixture of a more pure and healthy strain, give vitality to their offspring. If he lived to-day he would be surprised to see to what an extent this has been done and to the betterment of the old stock which was fast becoming an encumberance instead of a help, for not only has the offspring profited but also the pockets of the aristocracy.

So it has been in Trinidad, we now see a fine result, improving more and more every day which can be observed not only in our ball rooms but also in our professions where this admixture is gaining for itself a true position. That it should be so is only right and proper. Some there are who still try to kick against and ignore it, but believe me it is no use ; the lesson which Canute taught to his courtiers who wanted to make the old man think that he was pos- 
sessed of infinite power has still, I am afraid, to be learnt by many, and it is just as absurd to think that their puny efforts can stop the rising tide of the admixture of races undoubtedly to their benefit : this will, I am sure, at no distant day be an accomplished fact.

While preparing this chapter I was for a few hours in the company of a lady and two gentlemen, and on enunciating the ideas as here expressed one of the gentlemen said, "You must have been reading Trollope's book on the West Indies," I answered "I read some of his books but not the one on the West Indies, I was not even aware that he had written such a book ; if I had I certainly would have read it ; but if his ideas coincide with mine on this subject I am proud to be in such good company." The gentleman replied, "He has written a very fine book on the West, Indies and one of his chapters coincide with your ideas as you have expressed them."

I went to the Library next day and obtained the book. I regret that space will not permit me to give more than one extract from it ; but that is an important one and bears out what 1 have so feebly demonstrated. It reads as follows :-

"If the coloured people in the West Indies can overtop contempt, it is because they are acquiring education, eivilization, and power. ...... My theory - for I acknowledge to a theory-is this : that Providence has sent white men and black men to these regions in order that from them may spring a race fitted by intellect for civilization ; and fitted also by 
physical organization for tropical labour. The negro in his primitive state is not, I think, fitted for the former ; and the European white creole is certainly not fitted for the latter."

He further touches on matters that I have not ventured to approach ; I advise any of my readers who may feel inclined to know more of his views on this and other points, closely allied with it, to read chapters 5 and 6 from pages 73 to 100 of his work and they will find an interesting subject dealt with in a manner beyond my efforts. One difference being that he wrote of Jamaica in 1859 , I write of Trinidad from 1874 to 1912 . But in both the careful reader will, I hope, find indications of footprints deeply imbedded in the sands of time which will never be eradicated. A good deal of what Trollope prophesied in 1859 has become true ; let us hope that more of it will be fulfilled, as time rolls on.

An important question in this respect not touched upon by Trollope, is one which must strike any person who takes a friendly and intelligent interest in the constitution of the creole mixed races as apart from the original stock of either white or black. Will they be able, in the future, to stand prosperity in the creditable manner in which they have in the past stood adversity?

That they have stood adversity with heroic fortitude is well known to every reader of history ; but the time has not yet come when the question of how they will stand prosperity can be answered, that is a mystery which still "lies hidden in the lap of 
the gods." If the education which they so industriously have striven to acquire, and the knowledge of the world and the past history of other nations and other races which it has bestowed, will not enable them to stand the crucial test of prosperitynotwithstanding that it has opened up to them the learned professions which many of them adorn-it will have been acquired in vain.

Before concluding this chapter there is a marked change in female life in Trinidad that it delights me to touch on, showing as it does the wonderful strides they have helped to make in the progress of Trinidad. The introduction of this subject will also serve to display the true spirit that has arisen in our community, tending as it does to illustrate the willingness of females to bear their part of the burden of life imposed upon them, and rescues them from the sore temptation that through the idleness of bygone days was the lot of some of their predecessors ; and not only this but it also enables them to assist as bread winners and lessen the burden of the other members of their family.

When I came to Trinidad I was struck by the absence of female assistants in the stores, and so out of curiosity I counted them. I could only make out five-I have since been told that there were six, but one doesn't make much difference-and they in one store. For the purpose of this article I recently went round the principal stores in Port-of-Spain and found out that they, at the present day, employ over five 
hundred; adding to this another hundred as representing those employed as secretaries, etc. and those in the smaller stores I computed that in Port-of-Spain there are not less than 600. Embodying with this number those employed in San Fernando, Arima, Princestown, Sangre Grande, Couva and other centres of rural districts I think I may safely add another 200 or in all 800 . On every hand their employers sounded their praise. Is this not another great contrast, and a healthy one between the Trinidad of Then and the Trinidad of Now.

It may, and no doubt will, be said that the description of the inhabitants as here given is an exaggeration. To some it may appear so, to me it is not. I have simply recorded the impression made upon me by what I have for nearly 38 years been closely observing. Are all the women beautiful ? No, they are not. Are all the men athletic and wellformed ? No, they are not, but both compare favourably with - and often excel-many of their own class whom I have seen elsewhere, which sufficiently justifies me in writing what I have written.

An impression was, to a certain extent, sought to be made on me before I came here that I was going to be associated with people very little removed from savages-and indeed many who come still try to live up to that idea; but the sooner such an impression is removed from their minds the better it will be for all. This being so I was agreeably surprised to find a people the majority of whom were such as I have described. 
Even the poorer people who have not received much education are polite and courteous in their demeanour, consequently they expect to receive similar courtesy and politeness from others, which being misunderstood is often resented by new comers. Methinks I hear some fop exclaim "what_rot!" No, my friend, it is not " rot" and it is less so than the expressive adjective you tack on to it would imply. If you expect deference and politeness extended to you, you must extend it to others no matter whether they are of a higher or lower degree in the social scale; the people of Trinidad are not only entitled to expect but to receive it. I would be ungrateful did I not bestow this small meed of praise upon the inhabitants of this colony, of all ranks, from the majority of whom I have invariably received much civility, courtesy and kindness. 


\section{CHAPTER IX.}

PORT-OT-SPAN, AS IT WAS AND AS IT IS.

In describing Old Port-of-Spain it will be necessary to go back to the time when it was the chief seat of the Spanish colony to whom it belonged. In writing of a remote period I must necessarily refer to other writers and in this instance $I$ avail myself of the kind permission of Mr. Osborne Inniss, to take a short extract from a useful little pamphlet called "Trinidad and Trinidadians" published by him in 1910 ; it contains much useful information, quaint sayings and folk lore of Trinidad.

I do not intend to trespass too much on his kindness and will only copy two paragraphs which read as follows :-

"The streets were as wide as at present and ran at right angles, but there were only seven, running from north to south and three cross streets. The streets were Trois Chandel now Duncan St., L'Eglise now Nelson, Laplace now George, St. Ann's now Charlotte St., d'Herrera now Henry, Des Anglais now Frederick St., and Chacon-then in process of construction. These streets did not run higher than the present site of Duke Steet, as the bed of the St. Ann's River, or as it is now called the Dry River, ran 
along the present site of Park Street, to Pembroke Street, across Brunswick Square and down Chacon Street to the sea, which flowed at the front of the present site of King Street. So that the town occupied a triangular slip of land, bounded by the Laventille Hills on the East, the St. Ann's River on the West and the sea on the South. Governor Chacon, in order to allow of the extension of the town on the North and West, dug a Channel, from about the site of the l'Hospice, southward to the sea, and diverted the St. Ann's River into it, which is the present course of the Dry River. The old river bed was gradually filled up and the town extended over it.

"At the time of the capitulation, the sea came up to the present site of King Street, except at the foot of Charlotte Street, where the R. C. Cathedral now stands and where the Government buildings and the Barracks stood. The church was a wooden building covered with shingles, situated on the present site of Columbus Square and the burial ground was near it. The market was held on the vacant space to the East of the Eastern Market; there was no building, but each person erected his own little hut to sell in. From the end of Frederick Street, a mole of 700 feet long by 30 feet wide, extended into the sea, with a landing at the end 50 by 30 feet in dimension. The present Broad Way and its extension to the lighthouse, shows the position of the mole. For its protection, a battery was erected in the sea, of a half moon shape, connected by a drawbridge ; the battery still exists, in front of the News Room." 
The reader will observe that all these streets now bear English names, and the reason for the change, without doing violence to French or Spainsh prejudices, was that the town having been almost totally destroyed by fire on the 24th March, 1808, it became necessary to rebuild it. And here I may mention that the much maligned Picton although hard pressed for money for his defence, returned $£ 4,000$ which the inhabitants of Trinidad presented to him on his retirement from Trinidad, as his contribution towards the relief of the sufferers from the calamity. What became of much of the money voted by parliament, and otherwise liberally subscribed, is unknown, but it is asserted that the sufferers from the fire did not get much of it.

The task of rebuilding the town fell to the lot of Sir Ralph Woodford, and he, although retaining the original formation of the streets, naturally gave them English names. Thus we have Duncan Street named after Admiral Duncan ; Nelson Street after Nelson ; George Street after the then Prince Regent ; Charlotte Street after his daughter Princess Charlotte : I don't know which of the numerous Henrys had the honour of having Henry Street named after him.

Frederick Street, it will be observed was originally called Des Anglais, and it was given that name for the following reason : Captain Vaughan, then in command of a frigate named the Alarm, 32 guns, had been sent to act in conjunction with a Captain Skinner, in command of the Zebra, to look after French 
privateers which were doing a considerable amount of damage to English trade in these waters; they were dispersed and chased into the Gulf of Paria. Some of the officers from the Alarm who came on shore and visited a lady named Griffith, then living in what is now known as Frederick Street, were attacked by some of the privateers who had landed in Port-of-Spain. Vaughan hearing of this came on shore with a large body of men, and instead of reporting the attack upon his men to Governor Chacon, took the law into his own hand and severely handled every one whom he suspected of being concerned in the attack upon his officers. This nearly embroiled the English government in a war with Spain which was then at peace with England; it was, however, for the moment happily avoided and this street was thus called Des Anglais.

The streets running from east to west were named after the King, Queen, a Prince and a Duke ; Marine Square was so called on account of its having been recently reclaimed from the sea. Chacon Street, is the only one which has retained its original name; it was a well-deserved compliment paid to the last Spanish Governor, as Picton Fort remains as a monument to the first English one.

As the town was extended from time to time, we find the streets named after other celebrated men of that time beginning with Abercromby. I have thus, to a certain extent, brought Port-of-Spain down to my time and I will begin to describe it as it Then was and Now is. 
It will be remembered that I mentioned, amongst the tasks entrusted to me on my arrival was that of forming the town into a series of beats for the purpose of proper police patrols. The town lent itself to this being easily done, it being built in regular blocks. . I consequently adopted it and it was found to be successful for over 30 years. As this is an age of progress the system was, about seven years ago, changed into another, but whether for better or worse I am not now going to express an opinion.

A great drawback to an accurate estimate of the size and importance of Port-of-Spain was and is the want of a map giving the correct measurement of each street so as to show their entire mileage. One is at present in course of preparation ; it is not yet complete, but from it I have been able to roughly ascertain that the streets now measure about 58 miles, 54 of which are under the control of the Town Board and the other four under the aegis of the Public Works. When I came to Trinidad I saw this defect and tried to have it remedied. There was, however, a good plan, or map drawn to scale. In order to allow me to mark out and apportion the police beats, I had recourse to this scale and, by rough measurements of it, I was able to duly apportion the beats. My calculation made the measurement of the streets to be about 32 miles. This will show the wonderful growth of the town in the time named, which, of course, is because it now includes Belmont, St. Clair, Tranquillity, Shine's Pasture and Woodbrook within 
its boundaries. But it is still a wonderful thing for a West Indian town to have the mileage of its streets extended from 32 to 58 miles in the space of 37 years. In the same time the population of Port-of-Spain has increased from 30,000 to 59,658 , or nearly double.

The streets at the time of my arrival, and for many years afterwards, were in a wretched state, especially in the rainy season. Then some of them were literally mire tracks, and as for the footpaths, you could see where they ought to be, but otherwise, they were grazing fields for goats, of which there was an abundant supply always visible. To call them footpaths for the use to which footpaths-as their name indicates-ought to be put, was ridiculous; they were, if you like, man-traps with well concealed holes. Fortunately there were no motor cars or motor lorries then running wild about Port-of-Spain as there are now, for if there had been no one's life would have been safe, because all pedestrians had to walk in the road proper as distinct from the footpaths.

The side gutters, or street drains, were in a wretched condition. They were paved with all sizes and shapes of stones, simply laid down on the natural soil, as it was called, over which the waste waterand there was plenty of it-flowed continuously, affording a comfortable resting place and singing ground for the nice little frogs which so frequently enliven the place of their habitation by their melodious (?) piping. The overflow of this waste water had a useful effect ; in the first place it kept down 
the bad smells that otherwise would have arisen from the saturated filth, dregs of fish water, soap suds and house slops-often mixed with other things-indiscriminately thrown out after nightfall.

All this has been changed; the streets have had foundations laid, they have been properly macadamized and otherwise improved; the footpaths and side drains have been concreted; the flow of either clear or offensive water has been stopped; the innocent sweetly (?) singing frogs either destroyed or banished-banished to some other quarter is I think, the more accurate, because I sometimes when coming down St. Clair Avenue in the " gloaming " still hear them ; so I think does the Town Engineer, who had done so much to improve the town and remove this pest from other places. The old cesspits are almost things of the past, having been replaced by an up-todate sewerage system. Making foundations to the streets and properly relaying them was a thing much wanted, and now that it is in full swing must by degrees reduce the expenditure for their upkeep.

There is, however, another matter which I must not fail to record that did not reflect much credit on those who were responsible for the repairs of the streets. Year by year, just before the Carnivalparticularly the Carnival of 1881 to which I will refer later-broken stones were spread out on what were, and I believe still are, called the "French streets," that is, all the streets lying east of Henry Street. The police in those days were wicked enough to say this was done for the purpose of affording the 
various bands, who made them their " happy huntting ground," ready material for attacking them when they, as a Borough Councillor put it to an over credulous Governor the day after the "Cannes Brulé" riot of 1881, "brutally interfered with the people's innocent amusements." Such incidents in the history of Trinidad have happily passed away-never I hope, to occur again. The influential and educated people who were at the back of the ignorant demagogues who were responsible for it have also passed away, let us be charitable and hope to a better place "where the wicked cease from troubling." Nevertheless I could not refer to the Trinidad of Then without going more fully into the history of that celebrated Carnival, which I will do in another chapter.

It would Now be difficult for the rabble, even did it exist to the same extent as Then, to collect stones for the amusement of stoning each other and the police; the streets are not only well laid out but in many of the important, I may say all the important, streets the material now used in their construction would render it even difficult to dig them up, and a stray stone is a rarity.

What became of a large portion of the house rates collected for the upkeep of the Port-of-Spain streets and other purposes in my early days, was then a question often asked and never answered. Was it that the favoured few escaped having their rates collected ? or was there another cause ? I am unable to say; both were not only hinted at but sometimes 
boldly asserted. There was, however, no one who had the courage "to bell the cat." Better times fortunately arrived and these things are only memories of the past.

It may, perhaps, be asserted that what I hint at about the house rates is a gross exaggeration. Is it ? I could if I desired make it more plain. But that I am borne out in my assertion can be easily ascertained from a passage in Sir William des Voeux's work (two vols.)* In writing of an incident which came to his notice, while acting as governor of Trinidad during the year 1877, he relates that a high official who had to do with forming the boundaries of the town, had omitted his own residence, and thus escaped paying the ordinary Borough rates for many years. However, as I have said, these and other equally disgraceful matters are memories of the past, and so let them remain.

The first extension of Port-of-Spain began in the early eighties. This was the laying out of the Tranquillity lands (then the property of the government) into streets and lots, and putting each lot up for auction to the highest bidder at leases for 199 years at a pepper corn rent, with certain restrictions in the lease. The streets were laid out by the government, the Public Works being in charge. For the first time the people of Trinidad saw roads laid out with proper foundations and, as usual, there was a lot of adverse criticism, but to this day it shows the wisdom of laying proper foundations to streets and roads because

* "My Colonial Service," page 311. 
it is beyond doubt that these streets so laid out have required less repair than any others in Port-of-Spain, and this, in a marked degree, has kept down the expense of their subsequent upkeep. I ean personally testify that the street now called Stanmore Avenue did not for over 12 years receive or require the slightest repairs.

Tranquillity lands were laid out in the following streets :-Cipriani Boulevard (so called after the Mayor)-one of the finest streets in the town but sadly lacking in suitable dwelling houses, Victoria Avenue, Stanmore Avenue, Tranquillity Street and Tranquillity Square. There are now here about fifty dwelling houses, most of them of the better sort valued at an annual average rental of $£ 100$. Many of them occupied by the owners and consequently are not rented; but those that are bring the average rental I have stated. These streets and the square are, in many places, shaded by stately saman and other trees, always in leaf. In the square four sets of tennis courts are laid out and all kept up at the expense of the subscribers, and a bandstand has been erected, but the enclosing railings are at present in a bad state. There has been built by the government two fine schools with suitable residences for the head teachers; a well-equipped government printing office, with almost all the modern improvements of this art. Very fine work in printing of various sorts, book binding, lithographing, and other important work is carried out in this establishment. A roomy drill hall for the use of the volunteers has 
also been erected on this land ; the Methodists have built a nice, substantial stone church with a suitable residence for the minister. Then last, though I hope not the least, there has been built to the north of and on a portion of this land the up-to-date and commodious "Queen's Park Hotel," so called because it overlooks the noble park of that name, which contains over 300 acres of open pasture, on which are golf-links, a race course, several football and cricket clubs, with an electric car system running all round it and connected with the general tram system, of which more anon. Over this fine park can be obtained an uninterrupted view of a splendid range of lofty purple hills-almost mountainsclothed with fine tropical trees and verdure unmatched or unmatchable in-what are often misnamed-“" more favoured climes." These hills have many shady paths, some of them aspiring to the distinction of roads, by which an easy ascent can be made to the various points of vantage from any of which can be obtained an enchanting view all over the Gulf of Paria, the surrounding hills, beautiful sunsets and of where the town of Port-of-Spain lies, for the greater part hidden by trees through which towers, minarets, domes and steeples peep as it were above a sylvan scene. Lying at the south, east and west are comfortable dwellings and charming villas beginning with government house, the residence of the governor which is situate at the spectator's feet.*

${ }^{*}$ See Casual Wanderings, No. 1. 
The next event of importance in the extension of the town was the purchase of the abandoned sugar estate of St. Clair to the west of Port-of-Spain, originally bought for the purpose of forming a stock farm for the purpose of improving the breed of horses and cattle. There is a curious story told about this purchase. It was pretty well known at the time that the government were negotiating for its acquirement and, in fact, if I mistake not, it had formed the subject of more than one debate in Legislative Council, but its purchase for some reason or other hung fire. An Englishman who was here at the time got information, by some means, that the governor was very keen on its purchase and was totally opposed to the cheese-paring, beating down of the price asked and that he was determined to have the purchase complete without further haggling. This gentleman, being either very cute or being very well advised, instructed a well-known barrister to offer a slight advance on what the government, up to this time, had offered. His offer was accepted, the deeds made out and the purchase completed within less than a week. In the course of a few days he resold it to the government netting, it was said, $£ 2,000$ profit by the transaction.

St. Clair Avenue was laid out and when coppleted some lots were put up for sale and leased on the same terms as those of Tranquillity. All the land to the north of the avenue was retained as a stock farm and managed for many years by Mr. J. B. White. The portions to the south were to be sold, as I have 
said. Years afterwards Valsayn, New Works and St. Augustine were purchased by the government, and the stock farm was transferred to the new property and St. Clair became what it is. The removal of the stock farm naturally opened up the remainder of St. Clair for sale ; it was laid out in building lots and at present is occupied by the stately residences of clergy doctors, lawyers, and merchants and forms a fine suburb to the town.*

A fine road used as a popular drive by the inhabitants of Port-of-Spain, called "the Serpentine," has also been added. It makes a pleasant extension to the one around the Queen's Park and lends a considerable amount of additional charm to the drive.

There is still a large tract available for building purposes, which when utilized will add considerable charm to Port-of-Spain and make it what it is fast becoming, a delightful residence for tourists and invalids who do not wish to face the rigours of a northern climate. I may be asked what has this to do with the progress of Trinidad? It has a great deal to do with it, for although I do not deny that Trinidad together with other West Indian colonies, was at one time a hot bed of disease, yet such has been the progress in hygiene and improved sanitary arrangements that I am justified in calling it progress, and thus recording the fact that the West Indies ought to become during the European and American winter seasons not only a health resort, but also a delightful climate to reside in for at least that portion of the

* See Casual Wanderings, No. 1 
year. I claim no particular virtue for Trinidad over any of the neighbouring colonies, but as I have lived here continuously for over 37 years and have witnessed the great strides it has made I can speak with certainty about it.

One more word and I am for the present done with this part of the subject. The climate of the West Indies may, at first, appear to be trying to people of more northern climes, but if they will insist on wearing out their old warm clothing as " being good enough for the place," what is to be expected? With suitable clothing and mild exercise this inconvenience can be easily avoided and the cool nights will compensate for the extra heat of the days. The trade winds which blow almost continuously at certain periods of the year can be delightfally enjoyed sitting in the broad open verandahs of either private houses or hotels.

I have seen too in later years the sugar estate of Woodbrook abandoned and rented in lots to tenants to build just as you please. Later streets were formed, better cottages built, and it is now fast assuming the appearance of a good suburban residence for the better class of mechanics, store and shop assistants. It is a valuable property, about to be transferred by purchase to the Town Board for the sum of $£ 85,000$.* When this is done it will enable that Board to effect improvements that could not be done by private owners. I remember being present when the whole

* Since this was written it has been purchased by the Town Board for $£ 85,000$. 
of this property, including another large slice beyond St. James, was offered as it stood-mill, stock and everything on the estate-for $£ 9,000$.

Before concluding this part of my sketch I must not forget to include a delightful addition to the town by the erection of comfortable substantial houses on the old lands known as "Shine's Pasture," formerly used as a grazing land for decrepit mules and half-starved cows, and part of which was occasionally rented to circus proprietors. It is now one of the nicest parts of Port-of-Spain and when the trees and ornamental shrubs at present being planted in Victoria Square have grown they will render it an ideal residence and the square will, in a few years, be the finest in the town. It can, and I hope will be made a model to be imitated by the squares to which I have alluded in Chapter VII.

A sketch of the improvements in Port-of-Spain would not be complete without referring to the great advance made in the appearance of the stores and shops both in and outside ; the dry goods stores, of course, attract the most attention. This' in a large measure, is due not only to the better taste of the proprietors by adopting European methods, but also the assistants being so largely augmented by girls who by their courtesy to, and patience with, their customers have set an example-much appreciatedto their male associates tending not only to improve them but also this large branch of business. In my early days there were only two really decent and clean looking grocery and provision establishments in the 
town, viz : the Ice House and Rapsey's. Now they can be numbered by the score or more, in fact every "Portuguese shop," as they were then called, has become as clean and neat as those to be found in the best towns in Europe and the improvement thus becomes very marked.

At an important meeting of the Board of Health which was recently held to discuss sanitary matters the following statement made by Dr. Lota forms another satisfactory testimonial to the progress made by Port-of-Spain in this respect since his advent to the colony, forming a great contrast between the Trinidad of Then and the Trinidad of Now. It is copied from the Port-of-Spain Gazette of the 18th July, 1912 :-

"Dr. Lota said, that during the nineteen years he had been here, while in the past he had been called to as many as ten or twelve cases of typhoid fever in one day, it was seldom that he saw a case now. It would, therefore be seen that sanitary work had not been neglected in this town. He had been to many parts of the world and even through the West Indies and very seldom had he seen a place so well kept in sanitation as Port-of-Spain."

Port-of-Spain is fast becoming the best town in the West Indies and if others wish to keep up with it. they will have to bestir themselves. What I have so feebly described undoubtedly shows that the chief town of Trinidad must be taken as a sure indication of its prospects and prosperity. 


\section{CHAPTER $\mathbf{X}$.}

STATE OF THE ROADS IN 1874 AND LATER.

When road-making was first begun in Trinidad it would seem as if the persons who planned and laid them out had a very crude idea of how it ought to be done. With a few exceptions they followed the old Indian trails going straight to the point, up hill and down dale; over mountains and through winding rivers seemed to be the order of the day, and yet, with very little extra labour, the passing directly over mountains and so frequently through winding rivers could easily have been avoided; as to laying down any foundation to a road it did not seem to be thought of, and yet, as I have said elsewhere, the laying of a proper foundation to a road is the first important thing to be considered. Diverting a road so as to prevent it passing so directly over a steep hill, through or over winding rivers, though it may slightly add to its length and expense of construction, will add considerably to the ease and comfort of travellers and prevent the heavy strain on the animals used by them.

Let me give a few illustrations that will be familiar to most of the inhabitants of Port-of-Spain. Until recently the short journey of $31 / 2$ miles to 
Maraval village during the rainy season frequently could not be accomplished because the traveller would have to pass twice through a winding river, which after a heavy shower became a roaring torrent, thus forcing on him the alternative of either waiting until the river went down or returning to begin his journey another time ; and yet this, which was allowed to continue for more years than one can remember, was lately easily diverted by lengthening the road by not more than 50 yards. The Maracas road after passing to the north of St. Joseph is another example. This winding river could easily have been avoided in four places. The Caura valley road is another instance. One has to cross this winding river eight times in two miles and yet every one of them could be and were at one time avoided by a diversion. This diversion was made, but so badly that it was only fit to be used by either pedestrians or mounted travellers.

My first drive into the country after my arrival was made in the company of Mr. L. M. Fraser, at that time Inspector-Commandant of Police. We went by the eastern main road to Arouca. It so happened that this road was, for the first time in its existence, receiving a coat of metal, or, as it is familiarly called, macadam. When we got a short distance beyond the "toll gate"-there was a toll gate in those days -we saw carts dumping road metal down on what was called the natural soil, without the slightest foundation, and even then so thinly as to make me exclaim :- "Why don't they lay them down one by 
one ? it would take more time but it would be more evenly done." It was the most feeble attempt at road metalling that $I$ had ever seen and within six months had to be done over again It was no wonder, because, as I afterwards learned, the contractor was paid by the mile, irrespective of the number of cart loads of metal or the thickness of the layer of stones.

At this time the majority, if not the whole, of the roads of the colony were under the control of the Wardens and local boards, and the way in which they kept them in repair was as follows :-At the end of the rainy season they sent out a gang of men with mules and carts-the mules and carts being principally their own, for which they charged so much each day. The labourers began trimming the side of the road, as of course must always be done ; the parings were shovelled into the middle, the side drains were dug out and disposed of in like manner and then the whole was round-ridged. Whenever a river or stream was near a few loads of sand or gravel were carted and spread over the grass and clay as thinly as possible ; but as in most cases it was the only way to justify the use of the mules and carts, and the consequent charge for them, it had to be done.

It is somewhere said that it is unsafe to build your house upon the sand; but I think this advice was not strictly adhered to, as it was said the foundations of many houses and what are now flourishing cocoa estates were laid in this way. Whether they 
stood the buffets of time and storm is another matter. I know that some of them did not ; but notwithstanding this the foundations for many profitable undertakings were begun in this way. Those people had seen others in higher positions make " chips," and they naturally thought that they were equally entitled to do the same-a loose morality that ought to have been nipped in the bud.

When " crop season" began the roads that were used for the purpose of transporting the canes, sugar, rum and molasses were cut up, the grass, clay and sand converted into dust six inches deep, which, when the trade winds blew, made driving, riding or walking through it a difficult task. When the " erop season" was over and before the heavy rains began the same roads were hurriedly round-ridged again; the heavy rains soon levelled them, drove the dirt and sand once more into the side canals there to remain to be handy when the time came round for it to be again utilised, and so on from year to year. Is it to be wondered at that these roads were, in the dry season, deserts of dust, and in the wet season horrible quagmires, making travelling not only difficult but sometimes impossible ?

I have heard it asserted that the accounts for the mending of the roads in those days were never audited, and consequently it was never ascertained

* For the meaning of the word "chips" in this connection the reader is referred to an article in Blackwood's Magazine, of Jul $\vec{J}$ 1910. 
or ascertainable, what their upkeep cost. This may or may not have been true, but in either case a method of road upkeep although profitable to those entrusted to do the work was simply a waste of the public money.

In the days to which I allude it was unsafe for anyone to travel alone during the rainy season, and, therefore, travelling parties of three or four were generally arranged; a frequent combination of officials travelling on duty was the Warden, Magistrate and Inspector of Police with their attendants, each being supplied with a cutlass, light rope, or strong fishing line. The cutlasses to eut branehes and sometimes trees that had fallen across the sometimes narrow road so as to clear a way for the passage, and sometimes to cut roso, carat, timite and other brushwood with which to erect an ajupa to pass sometimes a whole night, and, perhaps, far into the next day, until the flooded river which could not be got over had gone down sufficiently to enable them to cross. The rope or strong fishing line was used to tie the poles together and fasten the carat, or other covering, to make the ajupa rain-proof. One sometimes met with an old ajupa erected by some former traveller, hunter or surveyor, whose business had taken them to the same locality. It was always necessary to carry food of some description and often cooking utensils in addition.

The distance from Port-of-Spain to Toco can now be traversed in one day-although, personally, I would prefer two-it then often took four and never 
less than three-I speak of the days before the railway was open to Arima. The rivers on this road were more frequently in flood and were the worst and most dangerous in the colony ; I once had to get the people on the opposite bank to draw myself, servant and mules by ropes across a flooded river.

A favourite way of making or repairing a bad piece of road was by " corduroy," that is cutting roso or other small hardwood trees and laying them horizontally across the road, and then spreading clay or as it is called "dirt" over them. This answered the purpose for a time until the small trees began to rot and then many a mishap occurred as the animals were frequently badly lamed.

Let me give here an illustration of the difficulties one had to encounter in travelling even a short distance. Many of my readers know the road from the Warden's house at Sangre Grande to the old police station at Manzanilla, a distance under eight miles, which can now be driven over in an hour or by motor in half an hour. The first time I rode over this short piece of road in the early eighties it took me over 7 hours to do it. I left the rest-house on the site now occupied by the Doctor's and Warden's residences, at 2 p.m. and did not reach Manzanilla until 10 p.m. About an hour of the time was spent in sheltering from a severe rain and thunder storm, and the other 7 in plodding through mud and slush-the thinner the better-reaching higher than the mule's knees. Were it not that the rivers on this road had been bridged over a few years previous, it would have 
been impossible to go either backward or forward, after the rain and thunderstorm from which $I$ had to take shelter. At "Calabash Hill" the people were obliged to leave the road and pass through a cocoa estate, to its great detriment.

When Captain Baker was Inspector-Commandant of Police he made frequent excursions through the length and breadth of the island. On one of these journeys he, with a party, took ten days in performing a journey from Arima to Blanchisseuse and thence to Toco along the North Coast and back to Arima ; it generally took five days. The small wooden bridges which were to be met with on this journey over ravines and small streams were in such a rotten state that no less than seventeen gave way under them, throwing some of the party into the water. From that day forth every non-commissioned officer of police in charge of a rural police station had to send in a weekly report as to the state of the roads and bridges in their respective districts, but that information was only useful to the police and Government officials who asked for it ; the general public had still to trust to luck. Anyway it had a good effect, it sharpened the public works officials. This description of the then state of the roads gives but a faint idea of what were the hardships that travellers and the smaller planters had to encounter in those days ; many thousand pounds worth of fruit and vegetables were allowed to rot on the ground, a total loss to the peasant proprietor, because he was not able to get them out to the market. Compare that state of 
things with what now exists and it must be acknowledged that the roads and the modes of locomotion have wonderfully improved.

A favourite occupation of mine when riding along the roads, when they had somewhat improved, when my duty called me to various parts of the colony, was to take note of the situation of the various mile posts on such roads as were provided with them. What I began as a pastime often afterwards served me in good stead and enabled me to give information to others standing in need of it, and, I believe, I can still remember most of them. They were not always accurately placed, but I believe this has been set right. In respect of this I remember an amusing story in connection with this inaccuracy. The miles on the Moruga road were not accurately indicated ; the Magistrate, an Inspector of Police and the Clerk of the Peace while riding along on the way to hold a Police Court entered into a discussion as to various distances between the mile posts and it was arranged to test them. On the next occasion when the corporal of police came to San Fernando for the monthly pay he was directed to time the distance between all the mile posts on the Moruga road and he accordingly did so. On his way back to his station, he was joined by the road officer of that district and as they rode along together the corporal frequently looked at his watch and made an entry in his memorandum book. When they reached Moruga the road overseer found that the rest house was undergoing repairs and there was no place for him to put up for 
the night, the corporal hospitably invited him to supner and slung a hammock in the court house for him to sleep in. After dinner, as they were quietly smoking, the road overseer asked : "What were you entering in your book as we rode along?" The corporal replied : "I have been told to ascertain if the distance, between the mile posts is correct, and I thought the easiest way to do so would be to take the time between each of them." How did you find them ?" asked the overseer, "I found them very irregular. The man who placed them must have been drunk when he was doing it ; between the 8th and 9 th posts only took ten minutes, while between the 9th and 10th it took over fifteen minutes; this cannot be correct." The overseer said : "It was I who placed then and you say I must have been drunk." "Yes," said the corporal, "you must have been drunk or very careless ; surely you can't ride between any two mile posts with the animal walking in ten minutes ? You must have been drunk." The overseer got furious and said : "I will report you for saying I was drunk, and also for being insubordinate to me as your superior officer." " Dont' be a fool, man," replied the corporal, " you are not my superior officer, and you may report me if you like." The overseer went sulkily to his hammock, left early the next morning, and true to his threat, did report the corporal.

The Governor of the day, who was a commonsense man, and enjoyed the joke, ruled in his minute : "Let the road be surveyed and if the corporal's 
allegations as to the distances are found to be correct the cost of the survey and the correct replacing of the posts must be done at the overseer's expense ; if on the other hand the corporal is found to be wrong he must pay for the survey." On a survey being made it was found that the corporal was right. What the upshot of the matter was history sayeth not.

Between Arima and Valencia there were three rivers coming down from the northern hills which crossed the road. Two, shortly after crossing, joined as one before entering the Caroni, of which I believe they form the head. These three rivers crossing a short but much frequented road of only six miles, when not in flood, looked very innocent, and there was consequently a considerable amount of traffic through them, particularly by the small shop keepers and peasant proprietors. But when they became mountain torrents and swept down from the hills with terrific force they were very dangerous-probably the most dangerous in the colony. As they were not bridged they had to be got over in some way or other and people became venturesome; hence many unfortunate East and West Indians with their donkeys, mules, produce and shop goods were swept away only to be heard of again when their dead bodies were, days afterwards, found a considerable way down the bank of the same or some other river into which it flowed. I believe that $\mathrm{I}$ am right in stating that $\mathrm{Mr}$. Wallen, late Mayor of Arima, lost three fine mules at one fell swoop in one of these rivers. All this danger has 
fortunately been removed. The rivers are bridged over and this six miles of road is now a credit to the Public Works Department by whom it is maintained and by whom the bridges were built.

To give a complete account of the state of the roads in those days would greatly surpass the limit which I proposed at the outset of these sketches. I have seen the old "Indian trails," formed before the advent of Columbus, converted into carriage roads over which the humble donkey cart and the fashionable automobile can now travel in comfort; I have seen places that it took three long, weary days of dreary riding to reach become accessible in as many hours. I have seen the main roads of the colony, ankle deep in dust in the dry season and knee deep in slushy mud in the wet, become well graded macadamed roads equal to any and superior to many in Great Britain. I have seen roads climbing in dreary Indian fashion straight up and down, over hill and through hollow, become diverted round the bottom of hills over which they climbed, thus making them accessible to all kinds of locomotion, I have seen many of the, at times, impassable rivers and mountain streams bridged and made safe for all to travel over.

I had hoped to be able to give a complete account of all the improvements that have been made in the roads of the colony, but I find that the space at my disposal will not allow it without compelling me to leave out matters that are of equal importance. I have shown that when I came to the colony the roads were under the control of either Wardens or country 
boards. Mr. Irving when Governor changed this, and they were put exclusively under the control of the Public Works, where they remained till some years afterwards when what are called local roads, were put under local road boards-which was a retrograde movement and a great pity-there was, however, a reason for trying the experiment which I am afraid has not been a success.

The main roads are still under the control of the Public Works since the time of Mr. Tanner, and continued under Mr. Wrightson and Mr. Bell, assisted by their able deputy $\mathrm{Mr}$ Percival Stevens-who has been connected with them from the beginning and taken an active part in all that has been done. I think that I have in a concise way shown what they were, and every one can see what they are, and by comparison contrast the vast strides made.

Improving and extending the old roads by hundreds of miles necessarily were followed by the opening of new ones to the extent of hundreds of miles into and through places Then only known to the wild animal and sometimes lonely hunter; others are in the course of construction and others again so traced out as to make them ready to be proceeded with. These together with 90 miles of railways, for many years in use and about 40 additional miles in course of construction, will, when completed, make almost every part of the colony accessible and render it an ideal land for strangers from northern climes to visit and dwell amongst us during the rigorous seasons of their own. 
The sale of Crown Lands, so freely offered and availed of within the last 30 years, for the purpose of growing cocoa and rubber plantations, in so many places originally jungles, has necessitated the extension of old and the formation of new roads so as to make these places accessible, and that this has been done is admitted by all who travel over them.

There is, however, still one drawback and that is the want of a few comfortable hotels in remote though accessible places where tourists could break their journey for a day or so and thus be able to visit places situated on branch roads, many of which are delightful spots, or take refreshment and rest for a few hours ; these hotels could also be used as a health resort. At the present moment I have six such places in my mind's eye-apart from Macqueripe Bay-viz : Balandra Bay and point ; Matura Bay at a place distant about a mile and directly opposite the present village-the most healthy place in Trinidad-Manzanilla point just over the Le Branche river ; Mayaro point ; Guayaguayare (Galeota point) and Moruga. I suppose this will come in time, and when it does Trinidad will become more prosperous Then than Now, thus reversing what I have been describing.

There is another equally serious drawback to the improvements that have been made, and that is either the entire diversion of roads passing through or bridging the rivers. I am afraid till this is done Trinidad will lay itself open to the accusation of being non-progressive. The health of Port-of-Spain has been improved and established on a better basis 
since the diversion of the road that used to pass through the Maraval river referred to ; but what of St. Joseph, Tunapuna, Tacarigua and Arima whose water supply is still contaminated by all sorts and conditions of men and beasts having to pass dozens of times through the rivers from whence these places draw their only water supply. It is not necessary to describe more accurately what so frequently takes place when animals pass through these rivers, we all know it without any description. I will again refer to this important matter when dealing with the "Water supply" of Port-of-Spain. However, with the exceptions named, Trinidad has improved by leaps and bounds by the progress made in its road and railway construction, which is indeed wonderful and makes a great contrast between the Trinidad Then and the Trinidad of Nou.

In conclusion it will, I hope, suffice to say that the old roads to the extent of hundreds of miles have been rescued from dust and mire and to such an extent that anyone leaving the colony Then and returning Now would not recognise them; they are now in a condition which reflects credit not only on those responsible for their upkeep but also on the colony at large. I have frequently heard visitors speak in high praise of them. The tourists can leave Port-of-Spain in the morning and having travelled at least $\mathbf{1 5 0}$ miles without passing over more than two of the same and return in time for dinner in the evening. 


\section{CHAPTER XI.}

\section{CASUAL WANDERINGS, No. 1.}

Having described the streets and extensions of Port-of-Spain, the roads of the colony as they were Then and as they are Now, it becomes necessary to afford our more athletic visitors a sketch of what can be seen during the course of an evening without much expense-mainly on foot. In order to do so I will ask them to accompany me for a quiet stroll to the places and in the way indicated in this chapter which will, I think, repay it.

Some people delight in rushing at railway speed by motor car through our level country where they have neither the time for nor the opportunity of seeing much as they rush through it. Of course every one to his taste and it is not my intention to dictate to people what they are to see or how they are to see it ; but I take the liberty of thinking that to many people a quiet stroll in the way here indicated will be the more acceptable and thus I reproduce-with the permission of the Principal of the Queen's Royal College-a sketch which was originally written for and published in the Chronicle of that institution. It will be seen that it was, as it were, intended as a guide to boys desirous of plea- 
santly spending their vacation-and I believe it has been availed of-but $I$ trust that neither its former publication or object will prevent it from appealing to tourists or visitors who may come among us. The attempt to describe the caves at Gaspar-Grande and a sunset are additional.

One day, during last vacation, I overheard two college boys loudly and vehemently discussing the real or imaginary merits of their respective forefathers. They were so intent upon it as to be unmindful of the amusement they were affording the spectators around them. I have been so used to this sort of thing, by people of mature age-who ought to know better-that it did not cause me any surprise. But I thought that if boys could so eloquently and vigorously draw upon their immaginations, or so glowingly describe the imaginary merits of their ancestors, they could equally, and perhaps better, describe and grow eloquent over interesting matters pointed out to them, were some one found to be their guide. It thereupon occurred to me that such boys might be induced to follow a useful and pleasant employment during their holidays ; and so thinking, I venture to suggest the means of enabling them to pass their spare time with profit to themselves and others.

Passing away from them, I began to outline in my mind a plan whereby two or more intelligent boys could follow out the idea here suggested, which, if followed will not only afford them pleasure, but, perhaps, be also the means of earning a little pocket 
money, by publishing an illustrated account of their rambles ; and, by dipping a little into the history of their native land (of which so many in Trinidad are ignorant) as disclosed to them by many of the scenes over which they pass, thus gaining for themselves and imparting to others useful knowledge, apart from that taught at school. Many English magazines would be glad to receive, publish and pay for such matter.

The boys indicated are to be equipped as " Boy Scouts," and a band consisting of one, at least, with a taste for, and a slight knowledge of, sketching; one with a good handy kodak ; one possessing the faculty of descriptive writing,-an attainment which, if practised, can be easily acquired-could, I think, find such rambles a pleasant and perhaps a profitable occupation.

I know of nothing so interesting as listening to a person who has a thorough knowledge of the places and things of interest in his native land and who is able to converse intelligently on, and describe them.

In order to give an idea of what I suggest, I will, in imagination, accompany them as a guide, taking them over some of the places that I have, time without number, passed over and enjoyed. These journeys can be divided into stages, and will take ten or twelve trips to be successfully accomplished, and may be spread over three or four vacations.

We will begin a visit on a Saturday afternoon to the "Oval" cricket ground, where we take our seats in the members' pavilion, take out our sketch and 
note books and kodak ; sketch, photograph, and write a description of the various and peculiar styles and methods of the players. We must not begin our description of the ground by bragging that "it is the best in the West Indies," because it is not, and will not be until it is thoroughly drained and resodded with a better and harder turf ; but you may say, and will be justified in saying, that it is picturesque and has the finest back-ground, unequalled in the West Indies and, probably in any part of the world; with this you must be satisfied. Probably other West Indian islands won't agree, but that won't matter.

After having written notes, outlined sketches, and taken snap-shots, we will wend our way up to the "water tanks", on "Knaggs' Hill." Having got there we will select a spot to the south and taking our seats begin our sketches. I am afraid that the objects of interest are too far off for our kodak. We will, therefore have to sketch and write our des. criptions. Look around and take in all there is to be seen, lying almost at our feet. There lies the glorious savannah, at this moment occupied by no less than six cricket and four football clubs competing for fame in the exercise of their manly games ; picturesque marquees erected, and a bevy of youth, beauty, and fashion of Port-of-Spain looking on, chiefly cheering their favourite football teams-for there is not the least doubt that this is the favourite sport with boys ; they love the struggle, they love the game, and, perhaps, the ladies also. You can refer to the large herd of cattle, numbering some hundreds, quiet- 
ly grazing-a delightful pastoral scene-lending still greater charm to it. You can describe the beautiful Botanic Gardens with their ever changing panorama of soft green hills in whose lap they are placed ; wild and cultivated flowers in glorious profusion, with towering trees and climbing vines one mass of bloom and colour, of such varied hues as will tax all your powers to describe, or do adequate justice to ; whose glory would make the dullest nature beam with delight. You can describe the city of Port-of-Spain with its towers, steeples and domes peeping their lofty heads as it were above a sylvan wood-land scene, lying in the near distance to the south; the homely dwellings and charming villas to the east and vest, beginning with Government House, the residence of the Governor, with its background of lofty purple hills ; the building planned in the shape of the letter " $\mathrm{L}$ " to perpetuate the memory of Sir James Longden, who approved of the plans and design, but did not remain long enough to enjoy its comforts or see its completion. Very few are aware of the reason of its design or, perhaps, ever noticed it, probably it will be news to many. It certainly did not serve to perpetuate his memory, for the memories of most of the good people of Trinidad are short, their time is too much taken up in the struggle for existence or the endeavour to amass a fortune, to allow them to dwell on such insignificant things as perpetuating the memory of a nearly forgotten governor.

Cast your eyes over the lofty Laventille hills, stretching in an undulating slope along the Eastern 
side, with a good path on the top running from one end to the other, over which I have ridden, not that I recommend it as a ride unless you have, as I had, a sure-footed horse. Near the south of the range of hills are situated two interesting objects. The first is the picturesque church of " Notre Dame de Laventille," an object of interest from a great distance, which can, on a clear day, be seen in San Fernandoa distance, as the crow flies, of at least 30 miles. A little to the south and lower down is the ugly martello tower called "Picton's Fort," which like the name of the eminent man after whom it is called has, notwithstanding rude shocks and length of time, remained to perpetuate his fame and glory. Describe the whole range of hills to east, north and west with the sea to the south enclosing Port-of-Spain in a magnificent amphitheatre.

Cast your eyes over the valley of St. Ann's ; have a peep at Coblentz, once the residence of Captain, the Honourable John Bell-Smyth and later of the Honourable Leon Agostini, his brother-in-law, during whose occupancy, royalty, in the person of the late Duke of Clarence and the present King, were entertained, in the days "when sugar was king." In front flows-if I may be permitted the expression - the dry river, not always so dry as it is at present, it often carries furious torrents, and is then a fine sight to look at. Some old books allege that quicksilver was found in the bed of this river, but, in my opinion, it was a myth, anyway, my advice is, don't waste your time looking for it, your labour will be in 
vain, it is non-existent, and never was there, except it was " salted" as was the case in later years (within my memory) when designing rogues, in order to enhance the value of a certain piece of land through which the stream ran, "salted" it with a small quantity of gold dust and nuggets.

Pass down the eastern side of the Queen's Park and describe the numerous buagalows and pleasant villas of wealthy merchants ; the handsome facade of the Colonial Hospital ; the neat Victoria Institute ; that hideous and barn-like Prince's Building, in which so many of your predecessors, and some of your fathers of the present generation, received their education, under less favourable conditions than you are now receiving yours-erected to entertain royalty in the person of the Duke of Edinburgh, the second son of the late Queen Victoria. We come next to the stately dwelling of Trinidad's " merchant prince ;" the commodious and airy Queen's Park Hotel ; All Saints solid little church; the fine residences on the St. Clair Avenue and Serpentine Road ; the Queen's Royal College ; "Hayes Court," the residence of the Bishop of Trinidad, so named to perpetuate the name and memory of the late Bishop Hayes, who, during his lifetime, worked so hard, yet withal, so liberally in the interest of his church, tolerant to all other denominations with that spirit of toleration which is the dominant characteristic of true christianity, and who, like myself, frequently penetrated to the remote parts of Trinidad, when they were not so accessible as at present; we often met and travelled to- 
gether in the performance of our various duties ; as Hamlet said of his father "He was a man, take him for all in all, I shall not look upon him again." We now come to the palace of the Archbishop of Port-ofSpain, erected and, I believe, designed by that eloquent, genial, witty, liberal-minded Irishman the late Archbishop Flood, who to show his great love for his native country imported Irish marble and red polished Irish granite as substantial embellishments to, an otherwise unpretentious building. Next in order comes that conspicuous, stately, white, Corsican House, built by another of Trinidad's former merchant princes, now the residence of a wealthy Bolivar merchant. Miniature Balmoral Castle next attracts our attention; and then we pass on to the St. Clair experimental and botanical station ; but principally used for agricultural experiments.

The afternoon having now advanced, and we not having finished our first day's ramble, must leave our lounge. We have described nearly all there is to be seen from this point of view, so we will come down, take the St. Clair car, and later transfer to the Cocorite and pass through Peru Village, sometimes called St. James. As we pass St. James military barracks, now the constabulary depot, we view the magnificent rows of Saman trees on either side, arching like a vast " Cathedral Aisle," over the avenue leading to the squat ugly barracks, (of which Sir Andrew Halliday in his book "The West Indies" speaks so disparagingly) that cost the English Government over 
one hundred thousand pounds and the country, through its unhealthy site, many precious lives.

Having reached the western end of Peru Village we come to the place where the English forces landed, wading waist deep through mud and water, to the conquest of Trinidad. Turn to the right up "Fort George" military road; visit each of the twelve sites on which the-(in those days)-big guns were placed to overawe the recently conquered inhabitants of Port-of-Spain, mostly French, in case of an attempt at revolution, and to defend it from outside attack. The making of this road, the placing of the "big guns," the erection of the Artillery barracks lying underneath "Fort George,"-now used as the leper asylum,-St. James Barracks, and "Picton Fort," cost over $£ 1,000,000$; all of which with the exception of St. James Barracks, had within a year to be abandoned, on account of their unhealthy positions, being found unfit for European occupation. St. James was also condemned, but as there was no palce ready for the troops they were allowed to remain as a temporary (?) makeshift till better could be found, but there they remained for years in a hot-bed of yellow and malarial fever, no better having been found. They were, however, as time advanced improved and they are Now much more healthy than they were Then.

Shortly after the forts were abandoned, they became so overgrown with bush and bramble as to be unrecognisable and their very position forgotten, except the one on the top where the signalling station 
now stands. They remained in this unknown position until a time came when it was again mooted to fortify Trinidad; a search was made, some old records found which disclosed where they ought to be, and after considerable trouble they were unearthed-or rather unbushed. An attempt, which failed, made to re-fortify them by importing " big guns," which they were not able to get even so far as the lowest platform on the left of Fort George road so they remain in St. James Barrack yard a testimony of the incompetence of another British Colonel.

The fort at the top has long been converted into a signalling station, and there the cannon still remain ; but it is not the highest, there is one still higher behind it which " commanded" the road up to the valley of Diego Martin as far as the signalling station on the top of the northern range called "the North Post," both are used for the peaceful purpose of notifying the mercantile community of the approach of the various crafts sailing towards the Bocas in order to enter the harbour of Port-of-Spain.

From the vantage point of Fort George we can see and describe a great many interesting things. First cast our eyes over the valley of Diego Martin, so named after one of Columbus' Captains, who finally settled in this part of Trinidad. Standing on this elevated spot, which commands the whole Gulf of Paria, avail yourself of the opportunity afforded of describing and sketching the enchanting panoramic view laid out before you as in an everchanging dissolving view. This noble gulf, the northern part 
of which forms Port-of-Spain harbour, is said to be capable of affording shelter and a safe anchorage to all the navies of the world, where neither cyclone nor hurricane can, according to past records, ever reach them, and in which they could manoeuvre to their hearts' content.

Describe the numerous islets, dotted over the South-western portion of the Gulf, and used chiefly as health resorts by the inhabitants of Port-of-Spain. Most of them you have often visited and there enjoyed the luxurious bathing for which they are noted. Let us take them in the order in which they present themselves to our view. Pelican, commodious, low, breezy and cool ; Caledonia, high, hot, and uncomfortable, and owing to the numerous rough steps (over seventy) inaccessible to invalids, its chief recommendations being its delightful bathing place. Next comes Craig, a mere rock with a comfortable little house, but, also on account of its numerous steps unsuited to invalids. Then the Immigration depot where newly arrived East Indian Immigrants recuperate for a short time, after their long sea voyage, before being allotted to their various future homes ; and where the overworked immigration staff occasionally rest from their arduous labours. Then Rock, " a nice little, tight little island," breezy and delightfully cool ; Lenegan's which is set apart for quarantine purposes, but seldom needed. Our attention next centres on Carrera with its convict prison, erected principally by prison labour under the separate designs of Harley, Fraser, White and Bourne, at 
various periods Superintendents of Prisons. Here too is a nice comfortable house used and honoured by the presence of the higher gaol officials, their families and friends, who have no hesitation in becoming temporary prisoners. Then Cronstadt, the residence of the prison medical attendant, who is also the District Medical Officer for a very large, and in some places remote, district. This is a cool and healthy island. Gaspar-Grande and Gaspar-Poco, where Apadoca, the Spanish Admiral, burnt his fleet rather than surrender it to the English ships when they were intent on capturing Trinidad. At this point it may be interesting to find out why these islets were named Gaspar, "which means Jasper," was it a man's name or after the precious stone of that name which is often of a red colour found in the veins embedded in masses in many rocks and sometimes as a rock of which whole hills are formed. Gaspar-Grande is, as many people know, in places formed of red rock, and this may have caused the name. Point out the places (two) where the Spanish forts stood, one on a high hill in Gaspar-Grande, and the other just round the corner, near Goodwille's house, the remains of which till recently, were still standing. The guns from these forts were, without let or hindrance, dismounted and shipped by an enterprising merchant to England, and there sold as old iron or brass according to their composition. Describe the many sea-side residences distributed all round the shore, with the historic one of "Boomshell Bay," so called from the number of exploded bombs found there, which at 


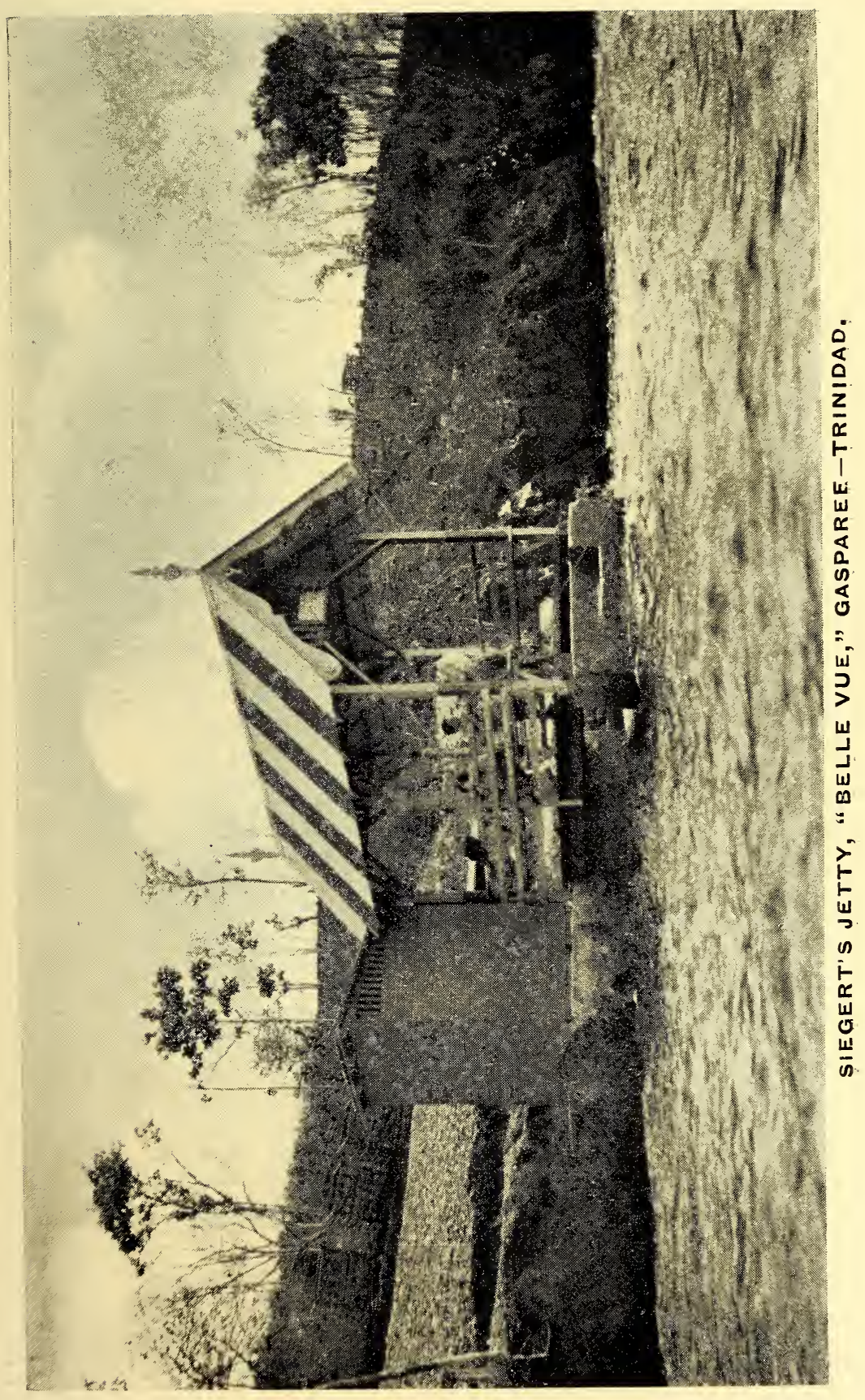



the time of the impending battle between the Spanish and English navies, were fired by the Spaniards at the English ships as they sailed round the Eastern point of Gaspar-Grande, many of them were fired from the fort in the centre of that island and some from the Spanish ships, but most fell short, some falling in the place now know as " Bomb-shell Bay" and exploding there.

This pleasant little bay has for many years been leased to the Constabulary, on the recommendation of a thoughtful and good-natured Inspector-General, with the approval of an equally kind-hearted and liberal governor, as a recuperative and convalescent health resort for overworked and overtasked members of the force. I heartily congratulate this deserving body on this well merited compliment paid to them by a generous executive.

There are two romantic caves to be found on Gaspar-Grande which can be explored by visitors, they being easily accessible. One is situated on the north-western point and runs almost from one side to the other ; torches have to be carried to light the way, it is in places difficult especially to ladies. The other, and by far the most important, is worthy of a special visit; it is situated near the centre of the island; access to it can be obtained by climbing a gentle sloping hill through the sides of which an entrance is obtained and from this point a descent has to be made by ladder to a gallery from which the visitor in enabled to see the whole grotto in its wondrous beauty rivaling the interior of the most gor- 
geous cathedral aisle. I am, however, afraid that time has made the ladders by which the descent was made when I first saw it unsafe and I advise visitors to supply themselves with a stout rope to serve as a substitute, I assure them that any trouble they take will be well repaid by the glorious sight.

There is a world-famed grotto called the Grotto Azzurra (Blue Grotto) near the town of Capri at the entrance to the bay of Naples which thousands of people visit yearly; but persons who visited both say that the one on Gaspar-Grande excels it in every respect except in the colour of the water at the bottom of both. In the early morning and in the afternoon a deep blue colour prevades Capri while the water at Gaspar-Grande although about sixty feet deep is not of such a lovely colour ; with regards the size of both, the Capri grotto would go into a corner of the magnificent one of Gaspar-Grande. It therefore forms an interesting object to be visited by travellers who visit our shores, and equally so to our own people few of whom have ever seen it or, I believe, even know of its existence.

Describe Monos (Monkey Island) with its many handsome sea-side residences, some named after celebrated English watering places, also much availed of by the good people of Port-of-Spain as health resorts. Huevos (spawn or egg of fish) with its solitary private dwelling next opens to our view ; the passage between it and Monos is the one chiefly selected by steamers; while the one between it and Chacachacare, is chosen, on account of its short 
straight passage, by sailing vessels. Chacachacare, is one of the few native Indian names remaining, on whose lofty peak is erected the useful light-house, possessing a powerful light capable of been seen for a distance of over thirty miles, indicating at night the passages called "Bocas" into and out of the harbours ; it is the largest of all the islets, and is only about five miles from the Venezuelan coast. But here comes a tropical shower with which we are so well acquainted; let us take a shelter till it has passed over ; don't think yourself inconvenienced by it, for you will shortly be repaid by witnessing that which once seen can never be forgotten. When the shower is over watch the setting sun apparently growing larger and larger till at last, with one mighty bound it disappears. Now keep your eye fixed for a few moments to the west and you will see the benefit which you have derived from the shower just passed. You will witness a glorious " Sunset" the beauty of which it is impossible to describe ; it must be seen to be appreciated, but once seen it can never be forgotten. Had it not been for the shower you would not have witnessed this glorious sight.

To my mind there is nothing more difficult to describe than a beautiful sunset. You can, even long after it has passed away, close your eyes and in imagination picture all over again the beautiful sight which has impressed itself upon your vision. This is easily done but when you come to put these thoughts and impressions into words the difficulty begins; 
even where you are, to a certain extent, successful the effort falls miserably short of the reality.

Many years ago, so far back as the evening of Easter Sunday in April, 1854, I, by good fortune, had the pleasure of accompanying a party to view the glories to be seen on the far-famed Lakes of Killarney. As we passed from one charming lake to another, all dotted over with small islets, fleecy clonds either languidly at rest, or gently floating over head, we had the good fortune to witness a glorious sunset in this enchanting spot which has never been, and never will, so long as memory lasts, be forgotten by me. In the early eighties of the last century, I again had the pleasure of witnessing from a peaceful islet on the borders of the Caribbean Sea, under the soft tropical sky of Trinidad, an equally if not more beautiful sunset than the one referred to.

Here as I sat in the western gallery of that nice sea-side villa called St. Mary's, near the north-west point of Gasparee, the past was suddenly called to my mind. The afternoon had been rainy but it cleared up about 5 o'clock. A lady-an artist of no mean order-the mother of one of our wealthy citizens, with members of my family sat beside me. Soon the clouds began to lift and we had the pleasure of seeing one of those beautiful tropical sunsets which once seen can never be forgotten. We sat facing the west overlooking Huevos and Chacachacare with the first Boca on our right to the north. We all, especially our guest and her daughter, who was with her, enjoyed that lovely sight, the former frequently ex- 


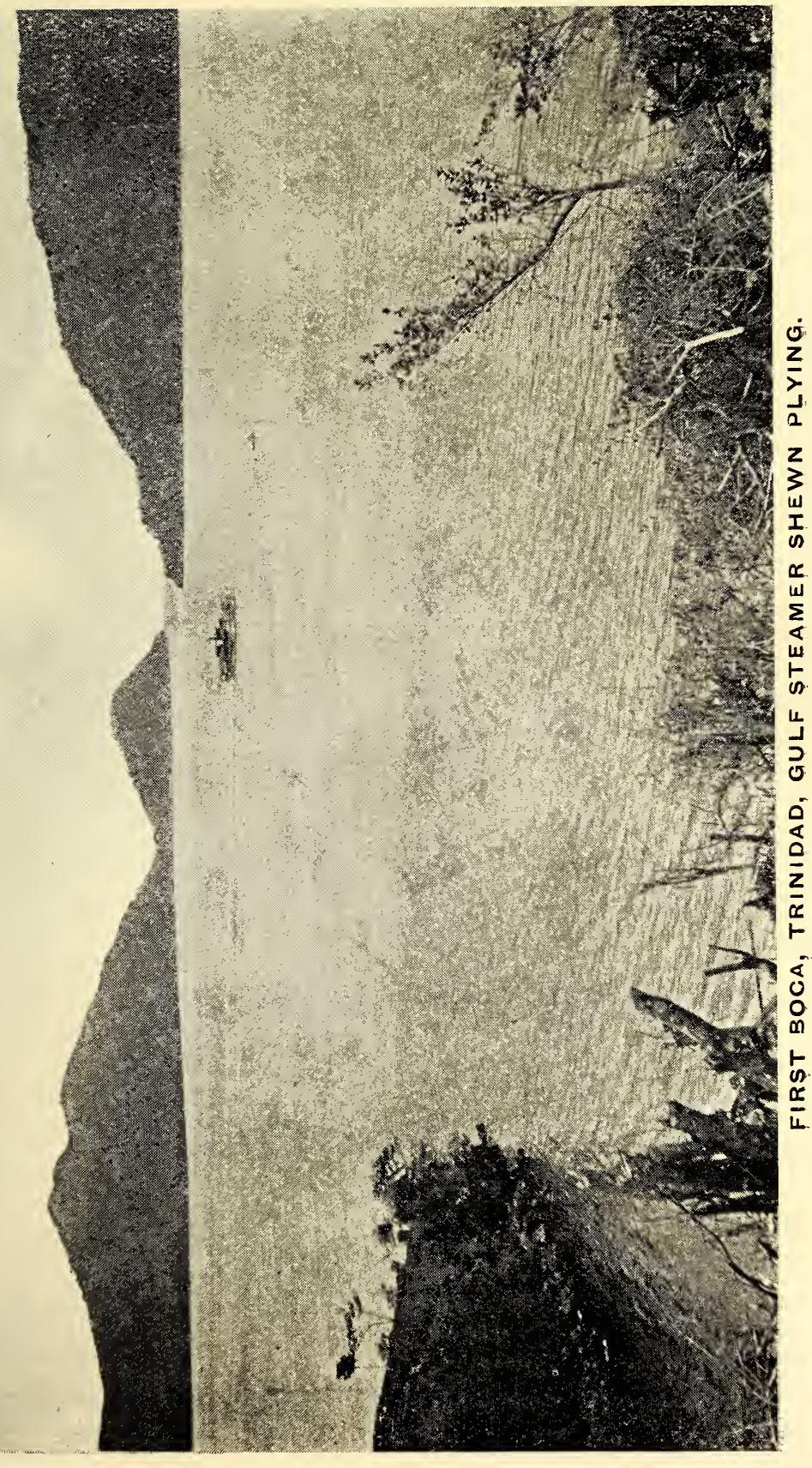



claiming " how grand ! how beautiful ! how enchanting ! I have never seen anything like it," and during the remainder of our stay in this pleasant little villa, of about a month's duration, she frequently visited us in anticipation of witnessing again and sketching one of these sunsets, and was seldom disappointed.

The lady frequently sketched them and blended her colours to match the varying shades. She afterwards painted and exhibited one which is now, I believe in the possession of her daughter.

While we gazed, the golden clouds, as the mist floated away, took the shapes of small islets in the middle of a vast lake; sail and row boats as it were gently gliding over the smooth surface, or spreading around and enveloping all in an iridescent flood of colour, so combined as to enhance "the living present " with fair scope for contemplating its beauty; a beauty which no words of mine can adequately describe.

Although of a more proasic temperament, I on these occasions, recalled the fair Easter Sunday referred to. There the back ground was the towering peaks of the high Killarney Mountains, clothed from the waters' edge to their lofty tops, with the glowing, shimmering, purple heather, then coming into bloom, casting varying reflections in the deep clear waters of those lovely lakes ; now deep blue; now pale green alternating and blending one with the other, intermingled with the colours of the rainbow, now this, now that predominating till at last one became so bewildered as to be unable to say which prevailed, and 
was thus forced to accept them as a new enchanting shade.

Here the shadows caused by the spur of the mighty Andes, itself enshrouded in a golden mist reflecting the glories of the departed sun, thus forming a suitable setting to the picture reflected in the waters of the Caribbean sea. Over the one "to memory dear " the beautiful sunset had lingered, frequently changing and intermingling its various colours, tints and shades; over the other it hovered as if instinct with life, and was loth to depart; in the one it could be viewed for hours of slowly fading glamour ; in the other a tropical twilight of short duration bade it depart, but not before it also had deeply sunk into the mind of the beholder where it will remain for ever.

I have seen many such since, all beautiful but none which remains so deeply impressed on my memory, reminding me as it hovered over the distant hills of Monos, Huevos and Chacachacare of Goldsmith's sublime though slightly altered words :

"Though round their breast the rolling clourls are spread, Eternal sunshine settles on their head."

Last of the islets comes Patos, a very uninteresting sight commonly called "Goose Island " there is not a single tree on it. Up to twenty years ago, this island was devoted to the breeding of goats, then one of Trinidad's " minor industries." Patos is claimed by the Venezuelan Government on the ground that it was not, as they allege, included in the articles of capitulation on the surrender of Trinidad by the 
Spaniards-who, at the time, also owned Venezuela. Be that as it may, the English now claim it, and hold fast to it.

We have now finished our Saturday evening's stroll, and as "the shades of night are falling fast," we will descend and wend our way homeward; we have done enough for one day ; and if you are satisfied with your guide we will wander forth some other day.

Before finishing this sketch I take the liberty of advising visitors to our shores, should opportunity offer, not to take leave of us without witnessing one of these glorious sunsets ; the place from which they can be seen is easily accessible, and I promise them they will be well repaid. They will often recall and dilate upon the beauties while reclining round their happy firesides-in a less genial clime-when the rain is beating on their window panes and the chilling wind is howling outside their doors, and so thinking or talking, wish they were once more sitting on the spot from whence they had witnessed the glorious glowing sunset in bright and sunny Trinidad and thus remember the poet's words :

"And while the rich tranquillity we view, Hope's sweetest promises again renew, As if the Twilight Angel hover'd there, To waft from nature's rest a balm for care," 


\section{CHAPTER XII.}

\section{CASUAL WANDERINGS, No. 2.}

It is not the intention of the writer of these sketches to attempt to describe all the beauty spots and interesting places to be seen in Trinidad. The two selected form an interesting portion of the Trinidad of Then and by bringing them under special notice form a great contrast of the places mentioned with the Trinidad of Now. The one here described is not so accessible to the tourist as "Casual Wandering No. 1." But the greater part of it can easily be seen in a few hours in one of four ways; either by walking, riding, motoring or by ordinary carriage ; the other part would have to be done on horseback and is a day's journey ; but, to my mind, it is, from a historical point of view, the more interesting.

In the sketch of our last wanderings, we finished by describing the sunset to be seen after a rainy evening floating over the Boca and the high mountains of Venezuela.

We will now take our way up to the Maraval valley and thence over the "Saddle" and wander to such places as our fancy may dictate. The valley of Maraval has become somewhat monotonous to those 
who either have been born in Trinidad, or are so long resident here as to become so familiar with it as not to be able to appreciate its beauties, and consequently think little of it. But it is not a place to be lightly thought of. On the contrary its scenery is something to be proud of. In order to fully realize this, take an intelligent artistic stranger for a drive over "The Saddle," stop at the reservoir, buried on the one side under towering hills-almost mountains-and shaded on the other by beautiful clusters of bamboo, reminding one of the old vast ruined Cathedral aisles to be met in various parts of Europe, and hear your delighted companion exclaim " how beautiful! how enchanting ! how romantic !" for it is indeed a scene enchanting to the imagination and pleasing to the vision of any beholder. Continue on through the picturesque little village, with its old Roman Catholic church elevated on a high plateau on the side of the hill, as if proclaiming its watchfulness over the spiritual welfare of the inhabitants. We might here turn to the left and pass over a steep road back to Port-ofSpain, by Petit Valley, Cameron Valley, Four Roads and the hamlet of St. James, which we have visited before; or when we pass a little out of the village in this direction turn to our right, and after a stiff climb come to the top of the hills overlooking the sea, a journey much affected and enjoyed by the late Honourable Clarence Bourne and his charming wife, when they resided in our midst.

Time will not permit us to visit either of these places, and, as we have already mapped out our route 
over "The Saddle," we will continue and wend our way through the remainder of the village, on through Moka estate and by the recently diverted and nicely inclined road to Santa Cruz. When we have got to the top, before entering the deep cutting through the steep range of hills, separating the Maraval from the Santa Cruz district, let us rest and take a glance, behind us at the landscape spread out before our gaze, dotted over by the small dwellings of peasant proprietors or agricultural contractors, converting what, at first sight, looks like barren hills into that which will, in the near future, become magnificent cocoa estates, thus showing that the genius and enterprise of man can prove more potent than Nature's hostile spell. While thus pondering over the picture of what might have been-and very nearly was-the fate of this now beautiful and prosperous valley for want of peasant cultivators, we are forcibly reminded of what might have happened in Trinidad when " King Sugar," the sole hope of the absentee proprietors, began its downward flow, whose tide was fast ebbing, bearing them out to an inhospitable sea, and were it not for "a bold peasantry, their country's pride," sugar making would have been numbered with the things of the past, instead of which it has attained a new lease of life which we hope may long continue.

We will now pass over into the fair valley of Santa Cruz, spread out like an enchanted fairy land, and gaze on the mighty hills with which Nature has surrounded this land of enchantment, as if to guard the golden treasure locked up within its bosom. We 
will take the road which sweeps along the base of the hills till we reach the road leading to Gasparella village and pass over part of the northern range in which is situated Tucutche, Trinidad's highest mountain, till we once more get a view of the ever varying sea, and wend our way to a part overlooking Maracas Bay, from which, by glancing to the north-east, we obtain a hazy glimpse of little Tobago in the distance, which though, till recently despised, at one time played an important part in the history of our Empire ; for the possession of which our ancestors -be we of English or French descent-shed rivers of blood, and, according to our inclination or patriotism, describe the valour displayed by either side. On one hill we can descry the great fort erected by the English, called " Fort George," and on another, and much higher one, the fort erected by the French commanding the greater part of the island ; the hill, long before, so often used by Robinson Crusoe for viewing the distant hills of Trinidad, and, perhaps, those of Venezuela.

We can by the aid of our glasses, and a little imagination, see Robinson Crusoe's cave surrounded by a pallisade, where he and his man Friday and the goats, lived in such awe-inspiring solitude. We can try to correct the erroneous idea that Juan Fernandez was the place of his enforced exile-although an error once established is hard to kill-still we must show something to bear out our contention that Tobago was the place of his enforced exile, and in support of it we give the following passage to be 
found on page 154 of the copy of the "Life and Adventures of Robinson Crusoe " in the Trinidad Public Library.

"I have told this passage because it introduces what follows; that after this discourse I had with him, I asked him how far it was from our island to the opposite shore, and whether the canoes were often lost. He told me there was no danger, no canoes ever lost; but that after a little way out to sea, there was a current and wind, always one way in the morning, the other in the afternoon. This I understood to be more than the sets of the tide as going out or coming in ; but I afterwards understood it was oceasioned by the great draft and reflux of the mighty river Orinoco, near the mouth of which river as I found afterwards, our island lay ; and that this land which I perceived to the W. and N. W. was the great Island of Trinidad lying to the North of the mouth of the river." (The Orinoco.)

Whether there ever was such a personage as Robinson Crusoe has nothing to do with our assertion, but if there was then the island of Tobago is the place intended to serve as a record of his exile, and to anyone studying all its surroundings from the place itself there cannot be the slightest doubt that in Tobago lies the scene of Defoe's thrilling story.

We will now continue our way down the graduated bridle road leading to and through Maracas Cocoa Estate, where the genial manager will place at our disposal a place to rest and partake of a well earned luncheon; those of you who wish to do so may take a 
dip in the majestic rollers sweeping so softly in from the sea. Having sufficiently rested we will invoke the assistance of the manager to lend us a boat and a few men to row us round the point into the bay of Las Cuevas, on the edge of which is situate Lord Rendlesham's magnificent estate, after which it is named. By adopting this mode of locomotion, we will, when we round the point and pass out a short way to sea, obtain a view of both the magnificent bays of Maracas and Las Cuevas ; but before we land let us visit the remains of the old Spanish fort at a point to the North of the bay, erected to, in some measure, protect the entrance to both bays. The destruction of this fort or Martello tower, occurred in this way-I quote from Joseph, he says :

"By false information and the errors of others, Nelson was made to believe that the enemy intended to descend on Tobago and Trinidad. On the 7th June 1805, his fleet appeared off the Northern coast on a point of which was posted a single Martello tower commanded by a French officer in the English service. One of Nelson's ships sent its boat ashore to get information at the fort ; the officer commanding it mistook the fleet for the enemy, and having no hope of defending his post flung the solitary gun over the hill into the sea, blew up the fort and set off for town over Tucutche spreading the news that the combined fleets were about to attack the island. It turned out to be a false alarm but it caused a considerable amount of fright in Port-of-Spain." This is how the old fort, the remains of which till recently could be 
seen, came to be destroyed. I have visited it on several occasions, twice before it became a total ruin as it now is.

The road over Tucutche, which the French officer alluded to took, is about an hour's ride from the bottom to top and it is very interesting -in some places almost enchanting; but it is on the wrong side of the mountain to enable us to get a glimpse of the ever changing sea. When we reach the top of the pass we will have to make another climb to the plateau on the top of the mountain ; this bit of climbing is very stiff, but it will repay the extra toil. When we reach the top we can, from our perch, gaze with admiration on the prospect laid out before us, language cannot paint it. From this point we can see the greater part of the remoter portions of the Island stretching out in various scenes unrolled by a gigantic panorama to the east, west, and south ; the north being behind we cannot be seen from this point. St. Joseph, although at least seven miles distant, directly south, appears to be lying at our feet ; San Fernando and the hills of Montserrat, with Chaguanas, Carapichaima, Tabaquite, Couva, Savonetta and Claxton Bay, to all appearances one wave of glistening green, whether it be the Sugar Cane with one texture, or the Cocoa plantations with another, either on the vast plain or the undulating hills proclaiming Trinidad's present prosperity. To our left, east and south-east, lies Tunapuna, Tacarigua, Arouca, Arima, Manzanilla, Poole and Mayaro, our view will not carry us further to the south or south-east. 
Arima was at one time the centre from which radiated the Indian tribes, although traces of them may be found, down as far as Cedros and Erin ; a quantity of arrow heads, stone hatchets and pottery were found at Erin about twenty years ago on the place where the Police Station is now built. Arouca was the chief pastoral lands of those who settled around Arima. It is said by some that the Caribs were the tribes that inhabited Trinidad, but many old family papers, preserved, and in existence down to 1838, showed that the original tribes were Arouacques and Chimas ; be this as it may, many of the descendants of those who radiated from Arima, can still be traced in the heights of Arima, Caura, Blanchisseuse and Sangre Grande.

After the Spaniards took possession of the island and began to establish some form of government they divided these Indian tribes into "Pueblas" or missions each under a "Corregidor" or Magistrate. Joseph relates an event that took place at a place called Arena, close to Mount Tamana, while one of these tribes was holding its annual festival-the date is given by Mr. Inniss as 1st December, 1699 . Joseph's account is as follows :-

"The other event is a remarkable revolt of the Indians who were settled in the centre of the Island, not far from Mount Tamana, at a place called Arena. By tradition, old papers and an old ballad, we learn that, as was customary, the Governor, the Cabildo, and the clergy went to witness an annual feast of the Indians at Arena ; and that in the middle of one of 
their warlike dances, the Indians, at a given signal, discharged a flight of arrows which killed the Governor, all the priests present, and most of the white people ; very few escaped. The Corregidor* of this Indian town or mission happened to be sick, consequently absent during the transaction; the event saved his life, but exposed him to the suspicion of being cognizant of the conspiracy."

Sitting as we are now, we have as already said, a splendid view of the greater part of the colony, for now Nature displays herself in the grandest majesty -in landscapes of surpassing loveliness, in mountain seenery, and in visions of water and woodland that are not easily comparable. We are surrounded by gigantic trees, most of them in bloom, and tropical flowers of every shade and colour. We have busy birds-great and small-hovering with glistening plumage over our heads and flitting about from branch to branch, the small humming birds sticking their long prehensile bills into every flower, their wings moving and making that pleasant humming sound from which they derive their name. But, alas, if all these birds have glorious plumage they are as Thomson says, deficient in the glorious songs one hears from their kindred in other climes,

"But if kind nature bids them shine,

Arrayed in all the beauteous beams of day

Yet frugal still she humbles them in song."

but still there are a few whose notes, though not prolonged are very sweet.

* Joseph gives the name I omit it 
As our eyes gaze around us, reaching to and peeping over, the distant cultivation both of plain or mountain ranges, rivers and streams by which we are surrounded we must be struck with wonder at the workings of, and provisions made by nature to provide man's wants. An old writer on Trinidad says, "The valleys which lie between the different ranges of the Northern hills are singular in their formation ; the mountains on each side rise so abruptly and correspond so nearly to each other in general, that the mountain wall of the valley seems a reflection of the other, appearing as though they had been cleft asunder by a violent blow from above." These hills are now under cocoa cultivation.

As we behold the several crystal streams, gently flowing towards the greater Caroni, we wonder how they could so often in the short space of less than an hour, become swollen torrents, dangerous to the life of man or beast who attempt to cross them while in their anger. They often remain in this state for days. On looking at the gentle stream passing now so gracefully by the village of St. Joseph, we are reminded of another event in Trinidad's history when Sir Walter Raleigh with one hundred men in boats stormed the then city of St. Joseph ; but so it was, and facts are stubborn things. Ask many of the people of Trinidad "Who was Sir Walter Raleigh ?" and they will answer you : "Oh, the man who spread out his cloak over a guttery place so that Queen Elizabeth might pass over without dirtying her shoes." They don't know of an important event in this illustrious man's 
life which took place on their own shores, but so it is. The town of St. Joseph-no longer a city-with its picturesque Church and tapering tower, reminds one of an old English village church and forms. a charrning prospect. St. Joseph ought to be a suburban health resort to Port-of-Spain.-Sir Rubert Boyce said, "Move Eastward "-it possesses all the requisites for the formation of a nicely situated suburban town-ship; it possesses a charming view to the east, west and south, and a delightful river-forming a plentiful water supply-at its base ; it could easily be laid out in accommodating squares and streets, and if, for this purpose alone, it is no wonder that the Spanish Government chose it as the site of their city. We will now descend and get a nearer view of the Maracas cascade. This in the rainy season is a sight well worth seeing. As we pass down to the village lying at the foot of the Tucutche road, we turn to our left and visit it. If the previous day or that morning has been very wet, the visit will repay our extra tramp ; we will see the water descending in one tremendous volume as if its background was one huge lake, bursting bounds with thundering sound rushing into the valley beneath. It is one of the noblest waterfalls in the West Indies. When we have spent sufficient time in admiring its grandeur, we will retrace our steps till we reach the high road and continue our way to St. Joseph through the valley of Maracas, and having passed through many flourishing cocoa estates-some of the oldest in the colony-and crossed the river no less than nine times, without the 


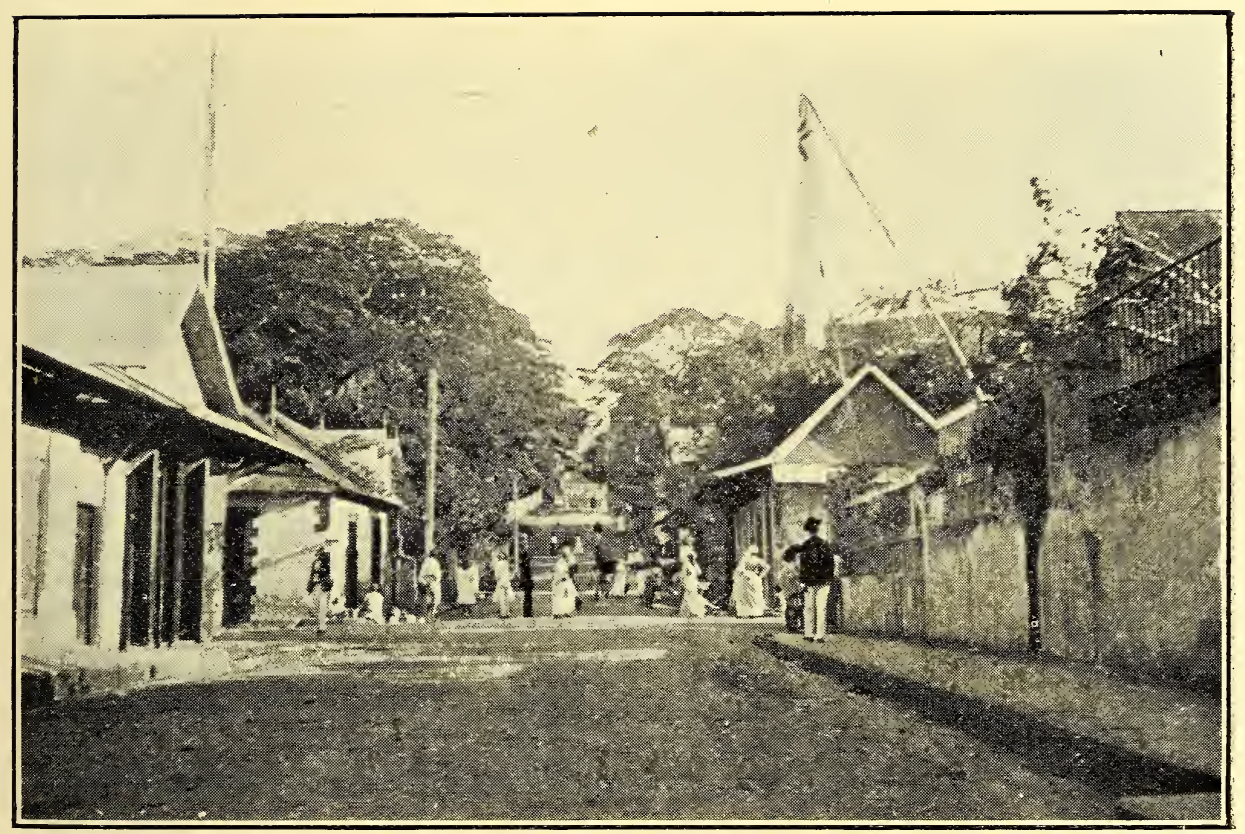

A STREET IN ST. JOSEPH. 

aid of a bridge at any point, we arrive at the ancient city of San Joseph.

Here let us pause once more and finish our sketch and ramblings for the day at least, by giving an account of a mutiny which occurred in the garrison stationed there in 1837. In giving this account we will again quote from Joseph's History of Trinidad; it is rather long so we will curtail it.

"Before closing my labours as an annalist of Trinidad I have to record a remarkable event which occurred on the night of the 17th June, 1837, viz. the mutiny of some newly imported Africans enlisted in the 1st West India Regiment. The revolt was led by a singular being called Dáaga, otherwise baptised and down on the roll of the regiment as Donald Stewart.".............

"Dáaga was the adopted son of a Madarshee, the old and childless king of the African tribe called Paupas, a race that inhabited a tract of country bordering on the Yarabas. Dáaga had been inveigled on board a Portuguese ship, a slaver, and treacherously seized and treated as a slave. This transaction caused in the breast of the savage a deep hatred against all white men, a hatred so intense that he frequently during and subsequent to the mutiny declared that he would eat the first white man he killed; yet this untutored savage cannibal was made to swear allegiance to the King of England, was baptised and then called a Christian and a British soldier."......

"This vessel on which Dáaga had been kidnapped was subsequently captured by the British, but in- 
stead of the slaves found on board being landed in their native country-Guinea-Dáaga with the others were brought to Trinidad and enlisted as soldiers. This untutored savage was unable to draw the nice distinction between being a slave and being a compulsory soldier; he knew that he had to perform work against his inclination and resented it. The consequence was that he consulted with his countrymen, whom he could influence, and a great many of the other African tribes in the same regiment, to join in the mutiny, promising them that he would lead them back to their own country. This account was afterwards fully corroborated by many of the mutineers especially those who were afterwards shot with Dáaga."'............

"Before this event a quantity of Africans having been brought hither from the Islands of Grenada and Dominica, were most imprudently induced to enlist as recruits in the 1 st West India Regiment. True it is we have been told that they did this voluntarily, but it may be asked if they had any will in the matter? How could they understand the duties to be imposed on them by becoming soldiers, or how comprehend the nature of an oath of allegiance, without which they could not legally speaking be considered soldiers ? I attended the whole of the trials of these men and well knew how difficult it was to make them understand any idea which was new to them, by the means of the best interpreter procurable."............ 
"It has been asserted that the recruits were driven to mutiny by the treatment of their commanding officer. There is not the slightest truth in this assertion; they were treated with fully as much kindness as their situation would admit of, and Dáaga was peculiarly a favourite of Colonel Bush and the officers of the regiment, but, notwithstanding this his temper often caused complaints to be brought against him.'........

" On the night of the 17th June, 1837, the people of St. Joseph were kept awake by the recruits, about 280 in number, singing their Paupas war-song

\section{"Dankaree au fey,} Oluu werri, au lay."

Which being rendered into English means

\section{Arr,--." Come to plunier, come to slay,"}

CHorus - "We are ready to obey."

About 3 o'clock in the morning the shouting became very loud, and they continued their war-song as given. "...........

"Fire was now set to a quantity of huts for the accommodation of the African soldiers, to the Northwards of the Barracks, as well as to the house of a poor black woman named Dalrymple. These burnt briskly, throwing a dismal glare over the barracks and picturesque town, and overpowering the light of the full moon which illumined a cloudless sky. The mutineers made a rush at the barrack room, and seized on the muskets and fusees in the racks. Their leaders, Dáaga and a daring Yarraba named Ogston, instantly loaded their pieces ; Dáaga had a quantity of ball cartridges, loose powder, and ounce pistol 
balls, in a kind of grey worsted cap. He must hare provided himself before the mutiny. How he became possessed of them, especially the bullets, I never could learn, probably he was supplied with them by his unmilitary countrymen, as pistol balls are never given to infantry. Previous to this Dáaga and three others made a rush at the regimental store room in which was deposited a quantity of powder and cartridges. An old African soldier named Charles Dixon interfered to stop them, on which Maurice Ogston, the Yarraba chief, who had armed himself with a sergeant's sword, cut down the faithful African. When down Dáaga said in English, "Ah you old soldier, you knock down," and then shot the fallen soldier. The war-yells of the Paupas and Yarrabas now became awfully thrilling, as they helped themselves to cartridges : most of them fortunately blank, or without ball."............

"At this period had a rush been made at the officers' quarters by one-half, and the other half surrounded the building, not one could have escaped. Instead of this they continued to shout their warsongs; they loaded their pieces indiscriminately with either blank or ball cartridges and sometimes small stones, and commenced firing at the long range of white buildings in which Colonel Bush and his officers slept. They wasted so much ammunition on this useless display of fury, that the building was completely riddled. A few of the old soldiers opposed them, and were wounded but none of the officers were hurt in the barracks." ......... 
"The Officers and Sergt-Major escaped at the back of the building, while Colonel Bush and Adjutant Bentley came down the hill. The Colonel commanded the mutineers to lay down their arms, and was answered by an irregular discharge of musketry, the stones or balls with which they were loaded rattled harmlessly amongst the leaves of the tree under which he and the Adjutant were standing. On this Colonel Bush desired Mr. Bently to make the best of his way to St. James for all the disposable force of the 89th regiment there to come to his assistance. Mr. Bently then went into the stable, saddled his horse, mounted and had to make his way through the mutineers before he could get to St. Joseph and thence by road to Port-of-Spain; he eventually reached St. James where the troops were collected and sent to St. Joseph which they did not reach till the affair was over."...........

"A body of Mutineers made their way towards Arima going east as Dáaga had promised to lead them back to their own country by this way. They were stopped at Arima by a company of militia stationed there."...........

"Never was a premeditated mutiny so wild and ill planned. Their chiefs, Dáaga and Ogston, seemed to have little command of their subordinates, and the whole acted more like a set of wild beasts who had broken their cages than men resolved on war. They did not even know how to place their muskets to take aim. They discharged them from their hips and held them more like mops than like deadly firearms. 
There can be no doubt that if they had known how to use their firearms few, if any, of the garrison would have escaped with their lives."

The mutineers were afterwards tried by CourtMartial appointed from Barbados, and after a lengthy trial and the evidence being submitted to the General at Barbados for final decision, three of the mutineers, viz., Dáaga, Ogston and Torrence were sentenced to be shot; and on the morning of the 16th August, 1837, the sentence was carried out, the condemned men standing by their open graves.

A fuller account of this sad transaction may be obtained by reference to Joseph's history.

Recently while digging the foundation for a tennis court about where these three men were executed and buried, a skull was found, which is supposed to have been that of one of those men, with a bullet hole through the forehead. Others of the mutineers were sentenced to various terms of imprisonment varying from transportation for life, to twenty years, ten years, and others terms of imprisonment.

Having finished our ramblings and sketch, we will make our way back to our homes. We have touched on many things, some of them, we hope of interest, and have slightly dipped into the history of Trinidad of Then and in a lesser degree the Trinidad of Now, as exemplified in the description of many cocoa plantations that have, within recent years sprung from desolate looking hills. 


\section{CHAPTER XIII.}

\section{IAA BREA AND THE PITUH LAKE.}

To write of Trinidad Then and Now without describing its world-wide famous "Pitch Lake" would be to ignore one of its most conspicuous features, and not only that, but also one of the sources of its wealth, enabling it, as it has done, to tide over what at one time threatened to be a disastrous period in its history, and still continues and will continue to be its prop towards prosperity.

Many people are under the impression that this wonderful work of nature is a huge lake of water with pitch floating here and there on its surface, and indeed one of the writers whom I have recently read, unblushingly so describes it; he even goes so far as to state that he visited it and saw what he describes. I am afraid that he was either what many people, when they don't want to use an ugly word, call an Ananias-although why choose poor Ananias more than many other greater historical characters described in the same book has always been a mystery to me-or that he drew greatly on his imagination. It is not so, and I shall now set out to describe it not only as it was in my time but long before it. The first I shall choose is Dr. Anderson, who was in his day attached to the regiment stationed here some 
time early in the beginning of the last century, probably about 1800 . He was evidently a highly accomplished scientific man because he uses, in his description of the lake, scientific names for very commonplace things. Now as neither I, nor the majority of my readers, possess this class of education, I take the liberty of changing his terms into plain words; but in order to indicate them I have italicised them. I have been told that when a quotation is given it ought to be used verbatim. Well, perhaps so ! but as this book has no pretensions to be historical in the strict sense, and is written by a plain man for plain people I have here and there taken the liberty of changing words and phrases but not their meaning or application ; so therefore Dr. Anderson's terms are given in simpler words. His description is as follows :-

"A most remarkable production of nature in the island of Trinidad, is a bituminous lake, or rather plain known by the name of Tar Lake ; by the French called La Brea, from the resemblance to, and answering the intention of, ship-pitch,"......" Its situation is similar to a savannah, and, like them it is not seen till treading upon its verge. Its colour and even surface presents at first the aspect of a lake of water ; it is possible it got the appellation of lake when seen in the hot and dry weather, at which time its surface to the depth of an inch is liquid ; and then from its cohesive quality it cannot be walked upon."

All this is changed; there is only one place in the centre where the substance is liquid, in every other 
place it is in a fairly solid state as will be shown later ; but it must be remembered that Dr. Anderson's description of it, was written, over a hundred years ago. But to resume his description :

"It is circular in form, about three miles in circumference. At my first approach it appeared a plain, as smooth as glass, excepting some small clumps of shrubs and dwarf trees that had taken possession of some spots of it ; but when I had proceeded some yards I found it divided into small holes of water of different sizes and shapes : the chasms or divisions joining together through every part of it ; the surface of the small pools is perfectly horizontal and smooth, the margins of the side slope down till they join at the bottom. On the surface the margin of each bank is distant from about four to six feet, and the same depth before they join at the bottom, but some of them are wider and deeper than others. When I was there all these chasms were full of water which rendered my investigation of it diffcult ; the truest idea that can be formed of the little islands between each pool of water is to liken it to the back of a turtle. Its more common consistency and appearance is that of pit-coal....... As to the depth I can form no idea of it."

Dr. Anderson gives a much longer description but as I am sure my readers like variety I will now give some extracts from Joseph, already referred to in this book; his description is about thirty-five years after that of Dr. Anderson, and mine will be about forty years later than that of Joseph so the 
whole will be divided into nearly equal divisions. Joseph's account is also curtailed, it is as follows :"On landing a respectable looking village presents itself; here and there thick layers of asphaltum of several tons weight overspread the surface of the soil, appearing as though they had been placed there by man, although in fact these' layers have burst through the soil which rests on immense strata of asphaltum. This substrata affects the soil and the buildings on it in an extraordinary way; the posts that support these occasionally sink perpendicularly into the earth and asphaltum, but more generally the layers of pitch affect the posts so as to make them lean in an alarming manner, in an oblong direction, apparently endangering the structure, but this does, not alarm the inhabitants, who, of course build them of light material. Often when a house is on the point of falling, in consequence of the leaning to the right, it begins to resume its perpendicular and then gradually commences leaning in a contrary direction."

"Leaving this singular village you take a wide and good road to the lagoon, which is situate about five furlongs from it at an elevation of eighty feet above the level of the sea. The road is flanked with large cashew trees whose fruit is more luxuriant than any I ever saw; to the right is an elevation on which many small hills, half composed of particles of bituminous matter and is remarkably fertile; dark red and yellow pine apples are here produced, of matchless quality. The pine apples of 
La Brea is a species distinct from the common anna of the West Indies."

"At length you reach the place on which no hut can be erected; the whole lagoon is open before you. It presents a most extraordinary spectacle-one which words cannot describe and which the pencil has failed to delineate. This lake is about half a geographical league in circumference ; it is surrounded on all sides by dark woods, save towards the sea; the surface seems perfectly black during the rainy season, but in the dry weather it has a partial greyish hue ; it appears as though billions of tons of pitch had boiled up from the earth, from the effects of an immense subterranean fire which had been extinguished and left the asphaltum to cool in enormous bubbles."

"It is time that I conducted my readers towards the more active part of the lagoon. In order to do this we must approach from the side nearest to the sea. Here we encounter streams of petroleum slowly but perceptibly flowing. Let us advance with caution; as we sink ankle deep at each step; let us pause, there would be danger in advancing further ; behold these fountains which supply all these rills of petroleum; no man can venture near, that is the capital of the Demon of the lake Asphaltum, the Phlegethon of this subterranean Tartarus."

Mr. Joseph goes on to describe many other things which show that either things were very different in his day or that he had a considerable poetic imagination. The relation of them here would make 
this article too long so I will content myself by giving one more quotation from his history. He relates an old legend in connection with the supposed origin of "The Pitch Lake," related to him by an old half-caste Indian, who though still active at the time of relating the legend was not less than an hundred years old. It is as follows :-

"It may, perhaps, be worth while to here recount an Indian tradition connected with the pitch lake. Formerly (say the Indians) the spot on which stands the pitch lake was occupied by a tribe of Chiman, who built their ajoupas here, because the land abounded in pine apples, and the coast in oysters and other shell fish; the finest turtle and fish were taken and its clear springs were frequented by countless flocks of flamingoes, horned screamers, pauix, blue ramier and humming birds ; but the inhabitants of this Chiman encampment having offended the Good Spirit by wantonly destroying the humming birds, which were animated by the souls of their departed relations, the Good Spirit, to avenge their impiety, in one night made the encampment to sink beneath the earth with all its inhabitants ; the next morning nothing remained of the Chiman's village, but instead the Lagoon of Asphaltum appeared."

Joseph's legend-although only a legend-has a good deal of poetic beauty about it, particularly the idea of the pretty, timid, humming bird being possessed of the souls of deceased relatives. Such old religious feelings or superstitions-call them what you will-began with the world's beginning and will not 
end until it ends. We may not agree with them, but let us respect them. "There are more things in heaven and earth, Horatio, than are dreamt of in your philosophy."

\footnotetext{
"Handed from ages down; a nurse's tale... Which children open-eyed and mouth'd devour; And thus as garrulous ignorance related, we learn it and believe."
}

It was fortunate for me that I had not then read Joseph's description of the lake, for I fear if I had, although I am not a timid man, I would not have ventured on visiting it. Let me, however, be thankful that if what he graphically describes ever existed except in his poetic imagination, it had all changed long before our time. I have been on the lake many times and I never sank to my ankles in the pitch, not even so far as to cover the welts of my boots, nor did I ever inhale the poisonous gases he describes. What has become of the fountains of petroleum ? It is true they have appeared elsewhere on the borders of the lake, when bored for, but not on it ; if they existed in Joseph's time they disappeared to appear elsewhere when artificial means have been adopted to find them and they now spout up hundreds of feet but are under control, that there were sure indications of petroleum, even in his time, cannot be doubted. Of this later.

In his graphic descriptions Joseph recommends to visitors that a pair of worsted socks be worn over ordinary stockings and that they should be kept wet and that no shoes should be worn so that every part of the lake (save the fluid part) may be traversed 
without injury to health. I have visited the "Pitch Lake" many times without the least inconvenience. I have walked over it, jumping the crevices containing water ; I have ridden and even raced over it on horseback, the water crevices affording nice jumps ; I have driven a pair of horses and dog-cart over it loaded with precious freight ; carts drawn by horses or mules draw heavy loads of pitch from the edge of the oozing part to the village of La Brea there to be boiled into what is locally called epurée, thence to be shipped in barrels.

This description of earting the dry pitch from the lake to the village was written five years ago; a tramway worked by its natural incline now does the work of the horses and mules.

My first visit to La Brea was in 1877. Having finished my business in the village, with many hours to wait for the return steamer, I went up the road described by Mr. Joseph. I quite agree with his description, except as to the respectable looking village which he found ; it must have, like the Chiman encampment described by him, disappeared-at least the respectable part of it, which would have been difficult to find. In every other respect I agree with Joseph's description. The good road, then in existence also a few years later disappeared. When I reached the supposed lake, my great surprise was to find that there was no appearance whatever of a lake, as I always understood a lake's appearance to be ; it reminded me of what I had often seen in the immense tracts of the bog of Allen in Ireland, from 
which the peat, or as it is named there, turf, had been cut away and the excavations filled up again as is the practice, shrubs growing about here and there in a similar way; but I soon came to see the difference in substance. We walked across the place till we came to the spot where the soft pitch oozes up ; this cannot be walked over-at least I never tried and would not like to try to do so. There were many pools of water, some large, some small, but none over which an active man-and I was active in those days-could not easily spring. These pools vary in depth from two to four feet and serve as handy bathing places for the residents at La Brea who may prefer it to a sea bath ; it is said to be good for any one troubled with skin disease or rheumatism ; a few men were bathing and a good many women were washing clothes and bathing at the same time, both having on the same amount of clothing, which was next to nil ; the greater part of the washing of the locality is done here ; it makes a fine washing and drying place, the many rivulets affording abundant water and the dry hard asphalt serving as a bleaching ground. You hear some people say that you cannot stand for any length of time in "one place " without sinking up to your ankles; unless by "one place" they mean to specify the spot where the pitch is constantly oozing up, the assertion is devoid of foundation ; it certainly would be dangerous to stand on this particular spot, and then if you tried it, it would be more likely that you would sink up to and over your head and not merely 
to your ankles. I have also heard people lead their hearers to believe that the pitch is so soft in this particular place that you have only to dip a bottle down in it and fill it up ; it is true you may do so in the water but not in the pitch. The whole place, with this exception, is, as I have stated, easily passed over by an active man or woman. If there are a few days' continuous heavy rain, it is true it is not so easy, but even then if you are so inclined you can wade through it without any fear of it reaching above your knees unless you fall into a hole when perhaps you will get a ducking to your shoulders.

It is said that Sir Walter Raleigh on his visit to Trinidad caused his ships to be coated over with the La Brea pitch. In order to have done so he must have either taken it from the oozing place or boiled it down to a thinner consistency. Admiral Cochrane, afterwards Lord Dundonald, who had a concession of part of this place, sent two shiploads of pitch to England to see if he could find some use for it, or distil it into petroleum. He failed in both purposes and he then erected works at the place now called Brighton and endeavoured to manufacture paraffin candles. He also failed in this, but the remains of the works were to be seen in my early days, and I, on one of Lady Dundonald's numerous visits to La Brea pointed this site out to her. This will be more fully described under "Oil Fields." Soon after Lord Dundonald's failure to find a market for the pitch which he shipped to England, a colonist said what in a sense may be deemed to have been prophetic : "Should any 
discovery be made which will render asphalt a fit article for ordinary use, Trinidad could supply the world with it." Such a use has been found for it in street pavements and road-making and there are few places in progressive parts of the world where its use is not known.

When I first visited La Brea it seemed as if this wonderful product was then beginning to find a market, although to a limited extent,- - not a tenth part of the extent to which it has since attained. The export of asphalt in 1876 was 15,274 tons, in 1910 it amounted to 157,000 tons, bringing to the revenue of the colony vast sums. In 1876 there were four wellknown colonists interested in this industry, Mr. Finlayson, Mr. Tom Field, Mr. Conrad Stollmeyer and Mr. Charley Stollmeyer.' I believe Lady Dundonald and Mr. Previté were also interested in it, but their interests were represented in the interests of those I have named. Finlayson, Field, and to some extent the Stollmeyers represented the one interest and Mr. Conrad Stollmeyer represented Lady Dundonald's interest. I cannot say to what extent Finlayson, Field and Stollmeyer were jointly interested, nor, for the purpose of this article, does it in the least matter. Lady Dundonald, who was represented by Stollmeyer, did not at this time, seem to be actively engaged, but later she was very much so and came out to look after her own interest. At the time of which I write the lease to the Finlayson and Field combination was fast approaching an end and Mr. Finlayson was busy trying to dispose of his interest, especially before he lost 
his influence in the colony, he then being a member of the Legislative Council. He undoubtedly was the means of forming the present Barber Co. in their interest in the Pitch Lake of Trinidad.

About 1880, I suppose in consequence of what began to leak out, pitch began to look up, and even I, as a stranger having no concern in it could see this. Each time I visited La Brea the number of sailing vessels shipping pitch steadily increased. Many people who previously had, or seemed to have, no interest in pitch suddenly began to travel up and down to La Brea by steamer, particularly on Saturdays. After landing they wandered about the village, looking here, looking there, a labourer accompanying them delving into pitch, numerous villagers clustering round them, then separating and whispering together. In the meantime Mr. Finlayson was not idle, he made several trips to both England and America ; rumours of concessions were in the air and village lots began to boom, many private sales and purchases were effected before the owners of the lots, who sometimes did not live in La Brea, knew anything about the increasing value of their lots. The Wardens and Crown Lands officers were beseiged by intended purchasers and people began to wonder what it was all about. Then came the concession to what was, and still is, locally known as "The Barber Company." All sorts of rumours were in the air, the truth or falsehood of which I am unable to uphold or contradict; but one thing I do know-they did not always emanate from a taintless source, especially from those 
who failed to have a finger in the pie, if there was a pie ; but I do know, of my official knowledge, that great efforts were made to defraud the Government by those who were foremost in their suggestions of dishonesty about others. I could tell a rather good story how these frauds were brought to light and thus frustrated ; there are but two men in the colony besides myself who know of it ; they may disclose it if they like, but for my part I will let it pass.

Let all this pass. The concession was granted to a substantial company and that it has materially benefitted the colony from that time to this day cannot be gainsaid. Where, let me ask, is there the slightest proof that the Trinidad Government could have made better, or even equal, terms elsewhere? After the attempted frauds upon the Government had failed, litigation began, much to the profit of the barristers and solicitors engaged on either side; people began to find out, notwithstanding the proverb " he that toucheth pitch is defiled," that La Brea pitch. was not included, and that it was a very clean thing to handle. Anyway the much-maligned concession became an accomplished fact and remains to this day to testify to the large benefit the colony has derived from it, advancing beyond dispute the prospects indicated by it and a kindred industry, which we hope to see soon in full swing, adding further to the prosperity of Trinidad in an even yet more unprecedented degree.

Even within the short space of time since this description of La Brea was first begun to be written 
-now about five years ago-I am informed that the aspect of the place and its surroundings has so much changed as to be almost beyond recognition. This is chiefly due to the erection of the oil works at Brighton-which is, properly speaking, part of La Brea -and the erection of these vast oil works makes a visit to it still more interesting. I have previously stated in this chapter that the export of Asphalt amounted in 1910 to 157,000 tons ; in 1911 it amounted to 158,983 tons valued at $£ 179,146$, or within a fraction of being three times the value of the revenue of the whole colony in 1842 , which was only $£ 62,684$. It will, therefore be seen that the development of this source of prosperity is one of the most remarkable of the events occurring within my time. I think I am justified in this instance, as in a few others, in departing from the course mainly adopted by me of only writing of matters coming within my own knowledge and occurring within my time, and also be permitted to depart from this course by going back to a period anterior by at least 100 years, thus describing and comparing the "Pitch Lake" of Then with the "Pitch Lake" of Now. 


\section{CHAPTER XIV.}

\section{THE COASTAL SERVICE.}

The three preceding chapters are mainly intended to describe the places of interest in the colony such as, in a small degree, may be found interesting to travellers and tourists, mixing with their description a little history. There is still, however, another journey embracing many view spots to which I gladly call the attention not only of our own people but also of visitors who may be able to spend a few weeks amongst us, by taking a four days trip in the steamers that run round the island weekly, calling at many places where passengers can be landed, and undergo an experience that will give them something to remember and talk about, and bring them into contact with a class of people one does not meet in Portof-Spain, and not only this, but also give them a good insight to the out-of-the-way trade and products of the colony.

I know of no more interesting trip where so much is to be seen and learned, if the passenger is desirous of seeing and learning. This trip is not only interesting but cheap, costing only ten dollars for four days board, lodging, and travelling combined, you may, of course, have to spend a few shillings more 
but that is your look out; I am really surprised that more people do not take advantage of it. Let me describe it in my own way and in my own words as I began it over a dozen years ago, and now bring up to date.

Another advance for the development of the colony that has come under my notice and which will offer a fair comparison of the Trinidad of Then and the Trinidad of Now is the "Coastal Service"-much welcomed by those who had to get the produce of their places, be they large or 'small, to Port-of-Spain there to be disposed of ; and not only to them but also to those who had to visit remote parts of the colony along and around the coasts, for although it was not inaugurated for this purpose it was considered, and availed of, as a great boon. This must be apparent to anyone who has read my account of the roads of those days, and to no one in the colony was it more welcome than to me, by not only enabling me to more frequently visit the remote parts of the country with greater ease and what was of greater importance still, of bringing me into close contact with people whom I would not otherwise have had an opportunity of knowing, but it also enabled me to acquire a better knowledge of the coastal outline of the country.

To Sir William Robinson, as governor, is due the credit of inaugurating this useful service. It was introduced for the purpose of establishing and encouraging a banana and fruit industry and trade, then so much spoken of in the colony, when things were 
beginning to look doleful. I may here state that the banana and fruit industry was never started on a sufficient scale to even entitle it to be called a minor industry. That is now, however, beside the question, for although this service was introduced with one object it was soon seized on to profit another, and that it has done so is beyond doubt.

The first contract and subsidy paid for it was given to the Trinidad Shipping and Trading Company who retained it for two terms of five years each. It is now held by the Royal Mail Company. I have been intimate with it since the first trip, and so continued for many years, making as many as six journeys each year and sometimes more, and although I had to go through some hard work landing in all seasons and at all times of the day or night as circumstances required, I always so much enjoyed it that I strongly recommend it to others ; if the party consists of half a dozen so much the more enjoyable it becomes.

It now becomes necessary to describe it. We leave on a Monday or Tuesday moonlight night and go south. If the night is fine some of us can remain on deck sleeping in deck chairs. We pass through the Serpent's Mouth between five and six o'clock in the morning and see the low lying coast of Venezuela and the several delta of the Orinoco in the hazy distance ; we run along the coast line of Icacos,-where Columbus is said to have landed and interviewed "the fair race of natives" which he first saw after his discovery of Trinidad,-we go east till we pass by 
the Cedros mud volcanoes up to Chatham-perhaps close to the spot where the little islet "Guy Fawkes" lately rose from the sea in smoke and flame, -and on to Erin where the first landing is effected, and from whence one of the greater mouths of the Orinoco can be plainly seen.

Landing at Erin is sometimes easy sometimes it is not ; when I say not easy I don't mean dangerous, but the place being shallow the boats have to lie out a long way, and carts come alongside on to which the passenger is lifted in the strong arms of a huge goodnatured boatman, and started for shore about a quarter of a mile's jaunt; then lifted again on a sandy beach. The village of Erin is about a quarter of a mile distant up a fair road but unless there is either much cargo to be landed or shipped there will not be much time to remain on shore; it is seldom less than an hour and sometimes we may remain much longer, but whenever we are ready to go off to the ship again one of the boats is there to take us, when we will undergo the same mode of transport; if you don't want to remain long on shore we can generally be back in time for breakfast. From there we next touch at La Lune, and thence on to Moruga, and this is generally reached about 4 o'clock, where we can go on shore undergoing the same lifting in the brawny arms of the boatmen; we can wander up to Moruga Village and see the place where the West India and Panama line of Telegraph enters the sea on its way to Demerara. 



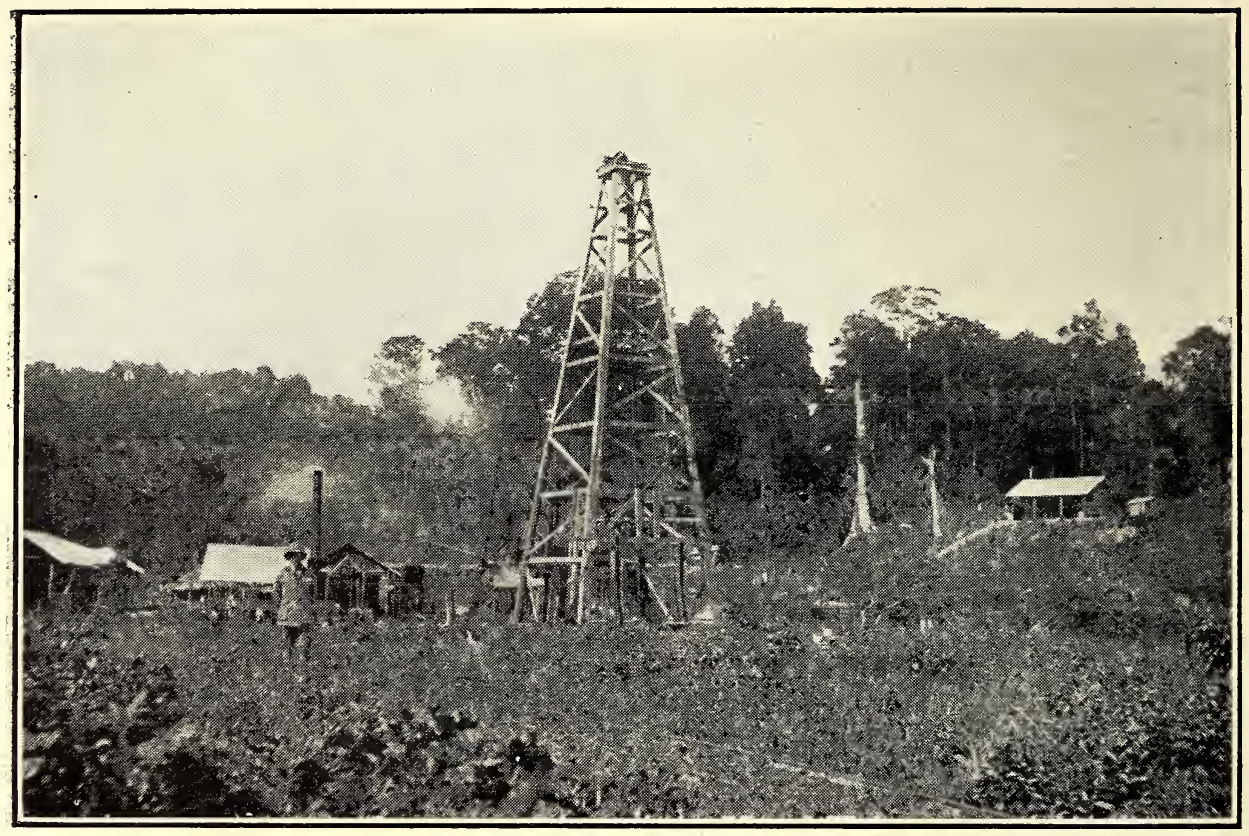

OIL WELL-GUAYAGUAYARE.

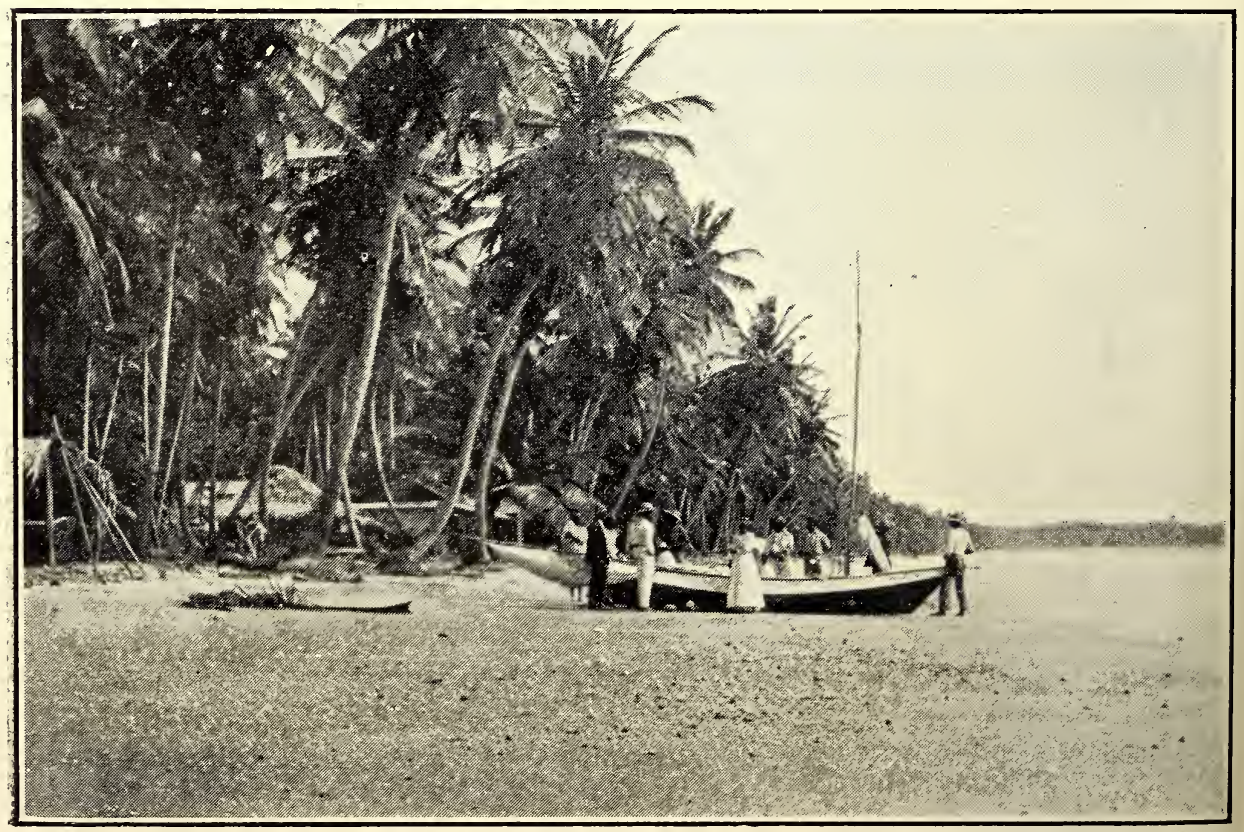


There is not much to be seen in Moruga but the neighbourhood is progressing and prospering by leaps and bounds and forms one of the greatest contrasts with the Trinidad of Then and the Trinidad of Now. From here a good road will take us to Princestown motoring in an hour, driving in about two and a half, and riding in about four ; in my early days I could not do it in less than eight hours, and I was fortunate if I could do it even in that time.

Leaving Moruga, if late in the evening, we do not see much, but if in the day time we run close to an interesting coast along which important cultivations are springing up, and near to a mud volcano that bursting into action a few years ago covered acres of land with flowing mud. A few places of call have been established of late, but as the amount of cargo shipped there is not very great there will not be time to land and see any of the country. The next place of importance and one which is so frequently spoken of is the so-called Trinity hills, said to have been seen by Columbus on Trinity Sunday, and from these three hills and it being Trinity Sunday he called the place "La Trinidad?" At least one of these statements cannot be correct because the 31st of July 1498 was a Wednesday ; for a further reference to this incident see Chapter II, page 33.

We next come to Guayaguayare, of which more will be said in the chapter on "Oil Fields," this practically being the place where this new industry was first started. The bay of Guayaguayare is very imposing, it is nearly two miles in depth, but, 
unfortunately a reef runs right across the bay from nearly one point to the other, and prevents vessels drawing more than 8 feet of water from entering near the beach, but a sail on shore in one of the steamer's cargo boats will repay the traveller, particularly if the day is fine. It, like many other places of Trinidad forms a striking contrast with the Trinidad of Then compared with the Trinidad of Now.

From this bay we pass round Point Galeota, round which Columbus sailed on the memorable 31st July, and sight the long beach of Mayaro for miles forming one vast panorama of cocoanut palms-a beautiful sight when first seen by the beholder. The origin of the cocoanut palm in Trinidad is accounted for in Kingsley's " At Last" as follows :-

"These cocoas, be it understood, are probably not indigenous. They spread, it is said, from an East Indian vessel which was wrecked here. Be this as it may, they have thoroughly naturalised themselves. Every nut which falls and lies, throws out during the wet season, its roots into the sand; and is ready to take the place of its parent when the old tree dies down."

Mayaro is a long beach about ten miles, and my advice to the visitor is to land at St. Mary's where the journey on shore is much shorter and the surf not so rough ; we can wander inland up a nice road for about half a mile to the top of a slightly rising ground from which we obtain a view for miles around not only of the cocoanut palm but also of the cocoa or chocolate tree which is fast becoming the staple 
product of Trinidad. Having satisfied ourselves, we can return to the beach and either return on board the steamer or wander north for about two miles to the next depot where we will see a factory engaged in all the operations of making coconut oil and copra; as we can see it all for ourselves it is not necessary for me to describe it. The nice carat covered bungalow, in which resides the lady owner of this magnificent plantation, has on many occasoins entertained royalty of various nationalities, and when we are introduced to her, if we are so fortunate, we will not be surprised, for a lady of more graceful manners, courtly demeanour, and genuine hospitality does not exist not only in Trinidad but in Europe. Before leaving try and obtain a branch of oysters for they grow on trees* close to this place.

Having been shown over the factory and satisfied ourselves with all there is to be seen, we are again shipped and sail out to the steamer, and having hoisted anchor we make for Manzanilla round the Mayaro point, keeping pretty far out to sea for here the water is shallow, but from the deck of the vessel we can see Mount Tamana, the centre of the island in the distance, and gently sail along in view of the famous "Cocal " of cocoanut palms, 15 miles long of which Kingsley wrote" This was the cocal ; and it was worth coming all the way from England to see it alone." We run into comparatively deep water at the extreme northern end of this bay and water.

* This is a fact with a reservation, the branch must be in the 
there anchor, but I do not advise a landing, we will see nothing but a muddy river, at certain seasons not sweet smelling, and plenty of mosquitos ; we can with the aid of a pair of field glasses enjoy the scene-and very interesting it is-from the deck of the ship.

Having landed and shipped the cargo, the ship next heads for Matura Bay or as it is marked on the map "Saline Bay" but more familiarly known as " Sally Bay." In crossing this bay, the coast of which can be more nearly approached than in Manzanilla Bay, we do not see anything interesting, it is, I think, the most barren place in fruitful Trinidad. I on two occasions had the peculiar sensation of feeling the ship touching a hidden rock, not marked on the chart; it is now known as McMillan rock, after the name of its first discoverer. It was fortunate that the good ship Magnetic was built of such sound material otherwise we might have come to grief. McMillan often said to me "they don't build iron ships like this now, she is without exception the best built iron ship I have ever seen," and at the time I speak of she must have been at least 30 years old, I remember her running in the early seventies between Belfast and Liverpool. There are two large rivers running into Matura Bay, which is one of the healthiest, if not the healthiest, locality in Trinidad. See page, 187.

Leaving Matura we coast along towards Toco and, if cargo offers, anchor in two nice little bays and so on round Point Galera where is situate the first lighthouse erected in Trinidad (fellow to the one at 
Chacachacare,) and from this point right over to Tobago, leaving Toco for the return trip. Having reached Tobago we can land at Scarborough-not quite so fashionable as its namesake in England, although it too has had its day when youth, beauty, and fashion were to be seen. It was at one time an important island and is looking up again. We can land at Scarborough and wander about the town; it is an interesting old town, and although hilly is well laid out. A trip through the island and round the coast is very interesting ; it has many fine bays worthy of a visit ; the roads have, of late years, been so much improved as to render the majority of them driveable.

Now back to Toco and while crossing we may see a whale and what is called a thresher having a fight, although there is good authority for believing that there is no foundation for these celebrated battles, the thresher being simply a peculiar species of whale, and the supposed fight is the action of his enormous fins in trying to dislodge the parasites from his back, thus making it appear from a distance as if there was a terrific battle going on. See Des Voeux's "My Colonial Service," pages 326-7.

Toco is an interesting place and here we come first in contact with Trinidad's magnificent range of northern hills many of them deserving the dignity of being called mountains. Toco is not at all times a pleasant landing place, it has been much improved of late years but in any case we are perfectly safe in the hands of the ship's boatmen ; I have no hesita- 
tion in saying they are the best men of their sort I have ever seen; but of this later. When landed we stroll up to an interesting village high up a gently sloping hill from which a magnificent view can be obtained. Toco is one of the places in Trinidad which has progressed in a wonderful way; it possesses some of the finest cocoa plantations in the colony.

In the old days, before Tobago was a ward of Trinidad, I generally landed at Toco where the steamer first touched before calling at Tobago, and from thence rode along the range of steep hills to Grand Riviere and thence on to Matelot. I will here describe one of these rides and relate an incident connected with it. Mr. Bulmer, then PostmasterGeneral of the colony, and I landed at Toco and informed the captain of the steamer that we would pick him up the next day at Matelot. Having finished our respective inspections in our departments and the afternoon being yet young we determined to ride on to Grand Riviere and there pass the night, which we did, and rode on the next morning over a very interesting, although by no means comfortable, road and arrived in Matelot about 10 o'clock. Having inspected our separate departments and taken our breakfast, we found that we had many hours to spare before the arrival of the steamer to take us on board on our homeward journey. We were pretty tired, for, as I have said, the ride is by no means an easy one. There was no room in the police station, which was a very small 
place, to sling our hammocks but the school room being a good size would suit our purpose. It was just on the verge of the time when the children would be let out for an hour to eat and play, and it struck me that if I could find in Collens' Year Book that it was the anniversary of some important event we might induce the school master to give a half holiday on the strength of it. It was the 11th of March and by good luck happened to be the anniversary of the death of a very exalted personage. "Bulmer," I said, "we are in luck, come out and let us interview the schoolmaster and enter our names in the visitor's book, mind you don't say anything to contradict me." Accordingly we entered the school and having entered into conversation with the master and praised his scholars, I, as if suddenly remembering an important event, said, "Sir, do you know I think this is the anniversary of the death of___ " mentioning the name-it was at the time of its occurrence a great historical event; "now there is no means by which you can impress any historical event on the memory of children better than by giving them a half holiday, and as it now close on their play hour it will just suit." He took the bait, and the children after hearing from us what an important part the high personage in question played in the history of England, they were dismissed from the school rejoicing and we, allowing a suitable time to elapse, availed ourselves of the large space at our disposal and slinging our hammocks enjoyed our well-earned rest. Some straight-laced people will 
say this was an immoral proceeding; perhaps so, but the immorality-if immorality there was-consisted in the act and not in the telling of it. If the children learned a portion of history that day so did I.

But to resume, as a guide to my visitors enjoying this trip. The steamer passes from Toco down the coast, most of which is in that ward, and ships the cocoa, which forms the chief produce, at various places. We will not land, as we are close enough to the shore to thoroughly enjoy the scenery and admire the hardihood and bravery of the boatmen as they toil through a not at all times smooth sea; how they overtop the mighty rollers must seem to you, as it often did to me from where we sit, an almost impossible task ; but they do it and do it well. There are many places of call but I do not advise a landing as we can see all there is to be seen from our safer seat on deck. I will, however, name them in their order, Sans Souci, Grand Riviere, and occasionally Petite Riviere, Matelot-the scene of the school story, Blanchisseuse-the White Washerwoman, on account of the white rolling breakers, Las Cuevas and Maracas Bay both of which are majestic bays and described in "Casual Wanderings No. 2," and the ship generally passes the night in one of them, and if moonlight it is sublime. Leaving one of these bays in the morning we gently steam along the north coast and come in sight of the coast of Venezuela, the old Spanish Main, of Buccaneer and Freebooter's times, and passing Macqueripe Bay-the intended site of a hotel, we enter the boca, passing the numerous islands and at 
length come alongside the jetty which we had left on the Monday or Tuesday night.

In order to pay a meed of praise to the men whom we have seen so cheerfully working in the boat and who have so gently lifted us, whether lady or gentleman, in their powerful arms, and landed us safely on the sandy beach, accompany me back to Mayaro. There watch them transferring the ship's goods into their boats, sail for shore there to land them, and when this is done, begin to load their freight from shore ; then observe the mighty efforts of eight or ten men to get their boats afloat, for all this time it has, to a great extent been resting on the sand, and when afloat they address us " Come on, sir," and once more lifting us in their huge arms gently place us on our seat, sometimes, as space is limited, on top of bags of cocoa; then another effort till the boat is truly afloat, then the command "in bow" of the head boatman ; observe if your heart is not in your mouth, the careful way which he watches each curling racing wave as it heads towards him, and then the word of command "all together" and the bow is lifted high up as she mounts over the crest of the huge breakers ; we need not be the least frightened, we are in the care of good trusty, heroic men, who know what they are about, and with two or three more "all togethers," high up and low down we go till we are safely over the last roller and in smooth water again, then up sail and head for the ship. 
I have in my day seen many men work hard, but I have never seen harder workers or better men than those I have from time to time accompanied on each of these trips, not only in the steamer but also in their boats to and from the shore, and I never met more cheerful workers. It gives me pleasure to thus record it, and I am sure, you, my fellow travellers, will endorse it.

The opening of this service has been one of the greatest benefits conceived or conferred by a governor, and if Sir William Robinson never did anything else to deserve the gratitude of the people of the colony, especially the planters, the owners of large estates, and also of small ones, peasant proprietors and shopkeepers all round the island, he deserves it for this as it enables them to get their weekly supplies and "ship" their produce, thus affording a wonderful contrast between the Trinidad of Then and the Trinidad of Now.

It is a pleasant educational trip, and I again repeat that $I$ am surprised more people do not avail themselves of it. To many there is still time to see and enjoy it; if you are not satisfied after your return, then blame me; but if you enjoy it you can thank me, either blame or thanks will be equally welcome, for I will feel satisfied that I have done you a good turn by inducing you to know more of this beautiful colony. If you are a stranger you will, like Kingsley, go home saying, "I am glad I at last have seen it." If you are a colonist, " I am glad because I know more of my native land than I did before." 


\section{CHAPTER XV.}

\section{TRINIDAD OIL FIELDS.}

The idea that Petroleum Oil existed in Trinidad is by no means of recent date, because we find it alluded to as far back as the beginning of the last century, in fact within a year or so after Trinidad became a British colony, and even before, for Sir Walter Raleigh, long before that time, must have had some idea that La Brea Pitch had something to do with petroleum. Dr. Anderson, alluded to in the chapter on La Brea, also mentions it, and some years after wards Lord Dundonald sank a well to obtain it, and did, but not in paying quantities. I have seen this place and have also referred to it in the chapter on La Brea. Joseph mentions that he saw running in rills on the lake itself. Kingsley in his "At Last" also mentions it, and as this account seems to be overlooked I here reproduce it :-

"We hurried along the trace, which now sloped rapidly down hill. Suddenly, a loathsome smell defiled the air. Was there a gas house in the wilderness ? or had the pales of Paradise been just smeared with bad coal tar? Not exactly; but across the path crept, festering in the sun, a black runnel of petroleum and water ; and twenty yards to our left stood under a fast crumbling trunk, what was a year or 
two ago a little engine-house. Now roof, beams, machinery, were all tumbled and tangled in hideous and somewhat dangerous ruin, over a shaft, in the midst of which a rusty pump-cylinder gurgled, and clicked, and bubbled, and spued, with black oil and nasty gas ; a foul ulcer in Dame Nature's side, which happily was healing fast beneath the tropic rain and sun. The creepers were climbing over it, and a few years more the whole would be engulfed in forest, and the oil-spring, it is to be hoped, choked up with mud.

"This is the remnant of one of the many rash speculations connected with the Pitch Lake. At a depth of some two hundred and fifty feet 'oil was struck,' as the American saying is. But (so we were told) it would not rise in the boring, and had to be pumped up. It could not, therefore, compete in price with the Pennsylvanian Oil, which, when tapped, springs out of the ground itself, to a height sometimes of many feet, under the pressure of the superincumbent rocks, yielding enormous profits and turning needy adventurers into millionaires though full half of the oil is sometimes wasted for want of means to secure it.

"We passed the doleful spot with regret..... for the good money which had been wasted; but with a hearty hope, too, that whatever natural beauty may be spoilt thereby, the wealth of these asphalt deposits may at least be utilized."

If Kingsley had been alive to-day he would have seen his hopes realized to the full and he would not 



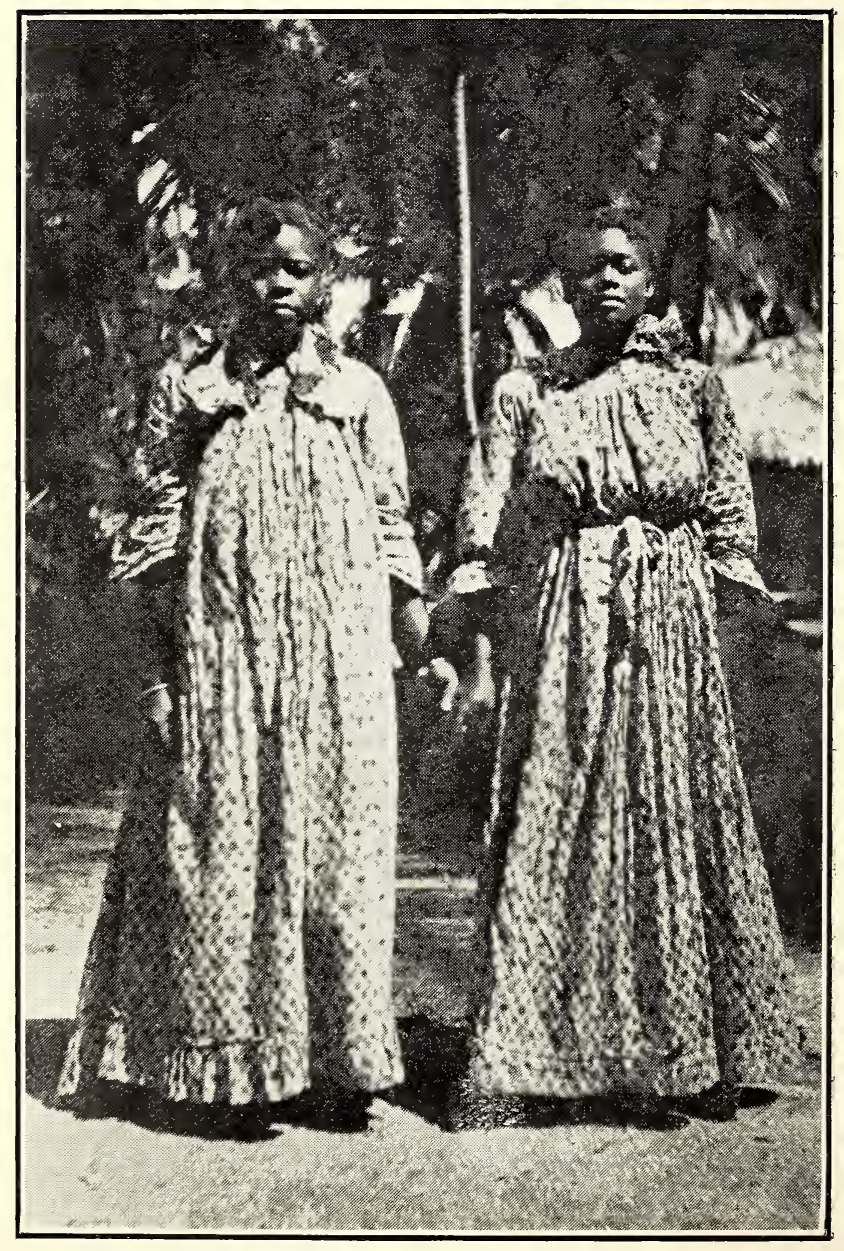

BELLES OF GUAYAGUAYARE. 
have expressed regret " for the good money that had been wasted." Time has proved that although it may have apparently been wasted it was not so in reality, because within a few yards of the same spot oil has been struck in large quantities and " mad Dundonald's scheme," as it was then called, has proved his wisdom, and instead of the oil having to be pumped, it spouts up to a height of 250 feet. Enough of this, I must come down to my own time, and of facts within my own knowledge. Of the attempts that have been made to discover and develop this as a profitable industry, it will, I think, be seen from what little beginnings vast results may be obtained.

Sometime in the early seventies of the last century the old firm of Turnbull, Stewart \& Co. of Glasgow and Trinidad, were the contractors for running what was locally known as "The Gulf Steamers." They had two, then, up-to-date paddle steamers, the Alice and the Arthur, nice comfortable boats. One at a time was only required for the service, but two were necessary to have on hand so as occasionally to relieve each other for cleaning or repairing purposes.

When not required for the Gulf Service, the Arthur undertook some commercial sailings along the suothern coast of Trinidad; she being the better sea boat could venture outside the Gulf to carry on a coastal trade mainly consisting of delivering shop goods at Erin, Moruga and Guayaguayare and loading cocoanuts on the return voyage.

On one of these occasions, Mr. Robert Taylor, chief engineer of the Arthur, having landed at Guay- 
aguayare, saw a black oily substance much thinner than liquid pitch but thicker than ordinary petroleum or, as is locally called, pitch oil, of which it had a strong smell, floating down a stream towards and into the sea. He obtained an empty oil can, capable of holding about four gallons, which he filled with this black substance, and, showing it to the captain of the Arthur, they held a consultation and carried it to Port-of-Spain, where it was crudely analysed and pronounced to be petroleum. The managing partner of the firm of Turnbull, Stewart \& Co., was not, however, satisfied with this, sent it to New York for a similar purpose and to ascertain its marketable value, where it was pronounced to be crude petroleum, but then of no commercial value, as the cost of refining it would render it unprofitable.

Some years passed and during this time nothing more was heard of it, but eventually another try was made in which an engineering and oil expert took part. The same Arthur took the party, and the expert having carefully examined the surroundings and taken samples which were again sent to New York, and a somewhat similar report was received; the question of refining largely entering into the consideration, and there was no other use for it, the idea was again abandoned. It was not thought of being used as fuel, and being an accessory to road making was not then in the air.

Time again passed and rumours spread that the oil at Guayaguayare was likely to turn out to be useful, and that a market was likely to be found for 



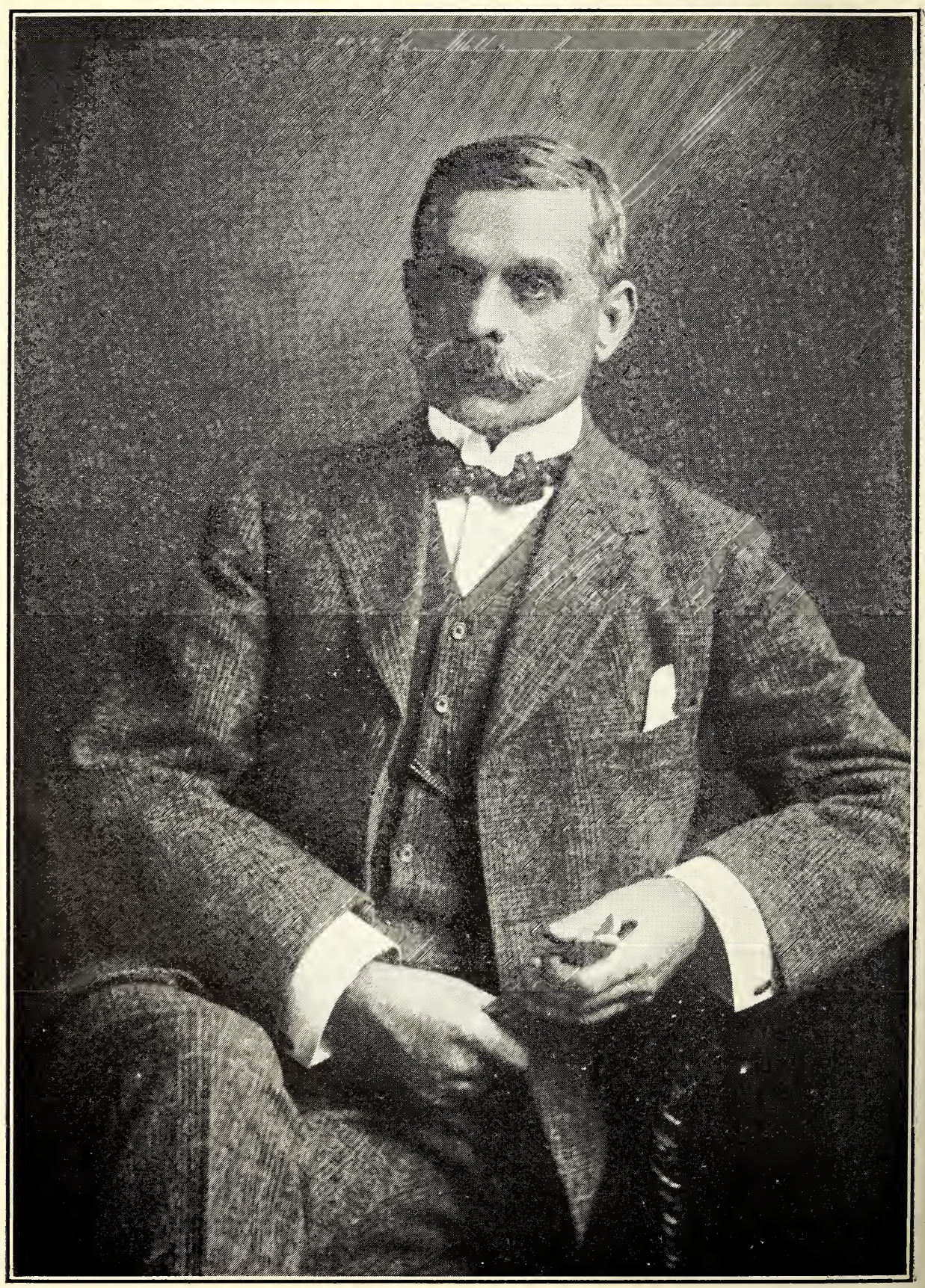

RANDOLPH RUST. 
it. Two gentlemen, one the Warden of the district, and the other of a speculative turn, to whom a license was granted to search for and obtain samples, took their way in an open boat from Moruga to Guayaguayare, a distance of about 30 miles by sea. Wind and current was strong against them and they had a pretty rough time before they reached a welcome shelter in Guayaguayare bay. A vivid description of the journey was given to me by one of the gentlen!ein indicated.

They remained there for some days and returned elated with their success (?) ; the one in hopes that he was in a fair way of obtaining what would, in all probability, turn out to be a good thing ; the other buoyed up by the hope that he would be able to report favourably to the government and that at last "Oil was struck." Alas ! for human expectations, this also proved abortive; the speculative gentlemen did not lay the foundation of a huge fortune and the government had still to hope on. It is somewhere said that "everything comes to him who waits," more particularly if he can wait long enough. This the government could, of course, afford to do and they did.

Eventually Mr. Randolph Rust came along ; a gentleman to whom Trinidad owes a lasting debt of gratitude, and whose portrait I am pleased to reproduce in this work. What agreement he entered into with the government he never told me, pioneers of new industries don't generally do so to men whom they know cannot help them either 
with money or influence, and, as I could do neither, I can only relate what I have been able to observe. Let other people say what they will, this much I can say, that Mr. Rust must be given the credit of being the real pioneer of the Trinidad Oil Industry, now, I hope, beginning to take a substantial shape. He ascertained beyond doubt that there is abundance of oil at Guayaguayare and that it was more than an empty dream. He met with rebuffs ; he met with discouragement ; he met with calamny ; he met with ridicule ; and, worst of all he, for many years met with disappointment. He, however, had the pluck to persevere, till I believe he is now on the verge of a huge success.

The London Financial News of Thursday, July 18th, publishes an interesting interview with $\mathrm{Mr}$. Randolph Rust. It clearly shows that Mr. Rust is still fighting for Trinidad and especially on oil industry. The following passage occurs in the report :"Then Trinidad has a priceless asset in its oilfields. I am speaking here from my own knowledge. I have spent the last twelve years of my life, to a great extent, in prospecting for oil, which was known to exist in Trinidad, though its importance was in former days derided by those who had never taken the trouble to go near the oilfields of Guayaguayare. Briefly our borings have revealed the existence of inexhaustible reservoirs of petroleum oil of the first quality. We have illuminating oil second to none, while of fuel for the oil engines, which are bound to revolutionize both the mercantile and war marines of 
the future, we have a practically limitless supply. The importance of our oil resources to the British Navy needs no elaboration. Trinidad, as the advanced guard of the British West Indies in the Caribbean Sea, is bound to become a great British base. The harbour of Port-of-Spain, properly fortified, would be impregnable. Already the Government is debating the spending of $£ 750,000$ sterling on the improvement of this port. Our shipping activity is even to-day considerable; there is not a day in the year in which some steamer does not enter our port, while it is impossible to limit our shipping importance when we become, as will shortly be the case, one of the ports of call for vessels passing through the Panama Canal, and going south to Brazil, the Argentine, and other South American lands.'

There is, as I have mentioned in the chapter "The Coastal Service," a substantial, though I believe a not irremovable, block to a clear entrance to Guayaguayare Bay; but why it should remain so, now that this bay is likely to be of such importance, is a question for the naval authorities to consider. A few thousand pounds sterling, and a hundred pounds avoirdupois of dynamite expended on it ought to clear a sufficient passage to render it the finest harbour in Trinidad and a safe naval base for a small fleet; this is, however, a matter beyond my ken, my present object being to deal with the oil prospects ; but if it were done it would enable large oil tank ships to go very close to the river up which Guayaguayare oil-wells are situated. 
I am at this stage unable to give a correct number of all the places where oil has been struck, but there are at least 9 in working operation, and this is, I believe, but a small fraction of the number that will, within a few years, be the case. While I write a paragraph purporting to have the outline of an interview relative to the Trinidad Oil Industry, appears in the Port-of-Spain Gazette. As the whole paragraph does not refer to oil I will only copy the part which does. It is as follows :-

"In the course of an interview with a gentleman who knows full well what he is speaking about, he expresses his strong belief in the big future which awaits Trinidad,"........ "Coming to our Oil Industry which is now in the forming, he regretted to state that it was greatly feared by those deeply interested that there is a strong current of wire-pulling with the object of shutting out the Oil Fields, in the interest of a combination of some strong companies who had formed a sort of secret trust to monopolise the affairs of Trinidad. It would be the very worst thing for the island if they got their desires, especially as the officials are simply playing into the hands of those people-consciously or unconsciously."

I would not publish this paragraph were it not that I think high officials ought not to be stigmatised as being conscious of "wire-pulling to the detriment of the colony ; " for, knowing Trinidad as I do now and as I have long known it, I am convinced that we never had a more honest combination of the higher officials of the colony than we have at the pre- 



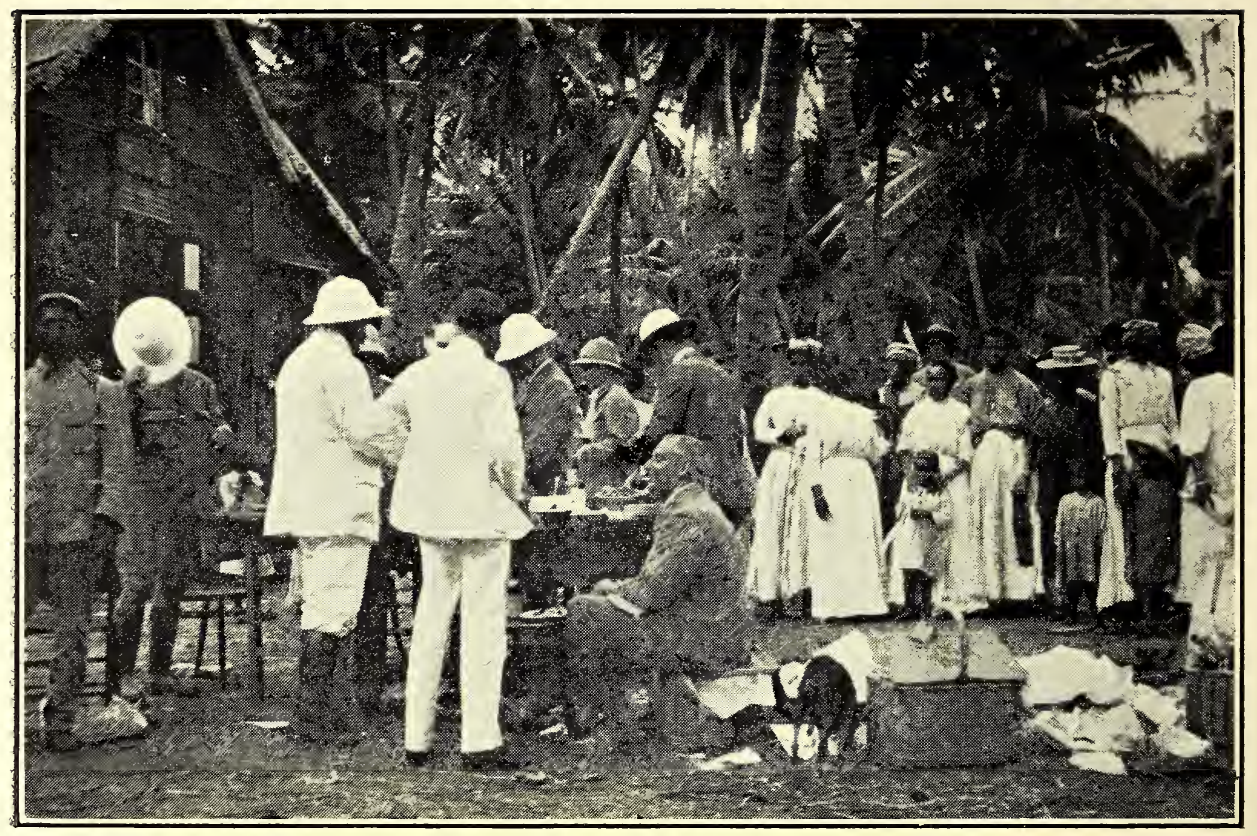

SIR GEORGE LE HUNTE \& PARTY-MAYARO BEACH.

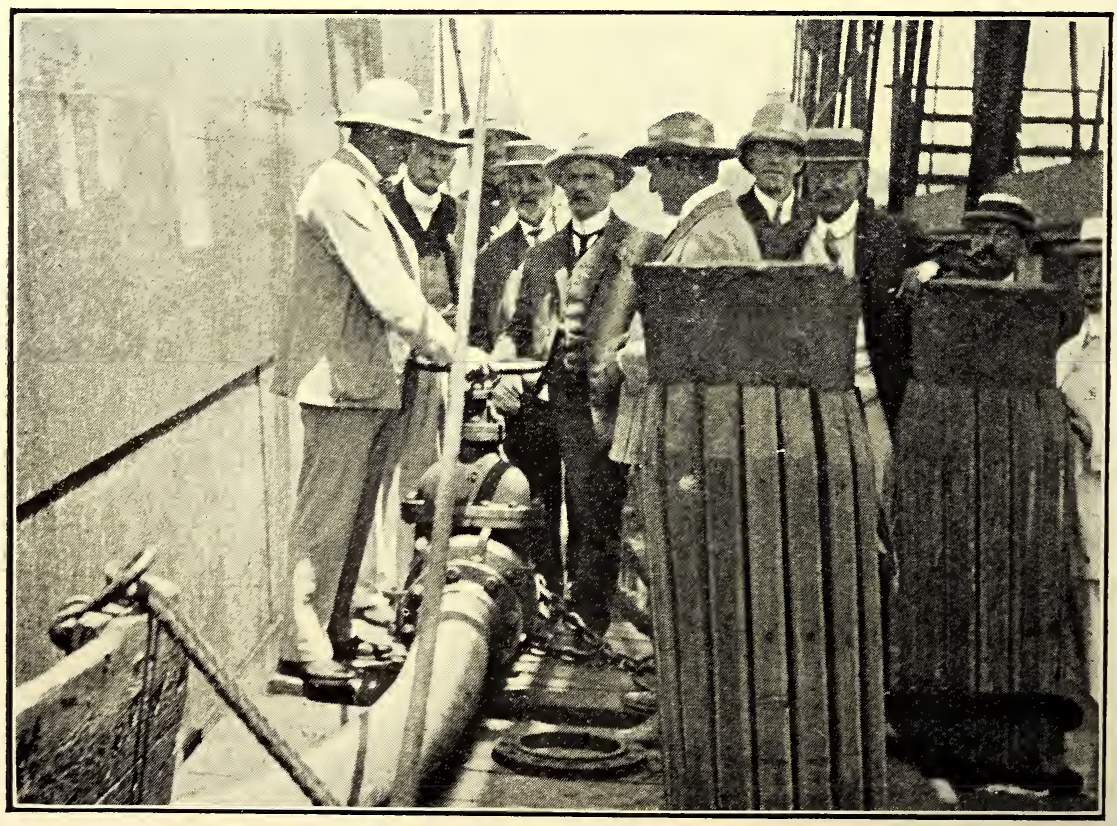

SIR GEORGE LE HUNTE TURNING ON THE OIL INTO FIRST TANK STEAMER "PRUDENTIA." 
sent time, and mud ought not to be surreptitiously thrown, unless there is the strongest proof, and then mud-throwers ought to come forward like men, as was at one time done in the past, when a Royal Commission was appointed to inquire into matters "Judicial," and by openly making their charges demand an inquiry. If the oil industry is being hindered by the connivance of anyone, be he or they in authority or otherwise, it must be known and it could easily be exposed. Unless the speaker or writer is certain of it he ought not to hint at it, and if he knows it or has good cause to believe it to be true, then he is not doing his duty to either himself or the community unless he reports it to the proper quarter unflinchingly, giving his reasons and the source of the information which has led him to this conclusion. Does anyone think that a professional burglar is frightened into not plying his trade because it is inserted in newspaper paragraphs that there is a large number of burglaries being committed ? Not he, he soon goes on as daringly as ever only acting warily and taking more trouble to cover his tracks.

It is, and must be good that the hidden treasures of heat and light to be developed in Trinidad should not remain for ever locked up and idle ; and so we wish success to the enterprising men who have engaged to develop this source of wealth. I would like to say more on this important subject; but I have said all my limited knowledge enables me to say and I do not wish to embark in groundless speculation. 


\section{CHAPTER XVI.}

NEW LOCAL INDUSTRIES.

By this term I, of course, mean those that have been started in my time. When I came to Trinidad there were very few of what could be called Local Industries. Sugar-cane growing; sugar-making and distilling of rum from molasses, skimmings, and drainings of sugar were in full swing to a much greater and more profitable extent than they are now, but, as time advanced, they began to decline till they eventually entered into a precarious existence under which they had to struggle for many years ; they are, however,-especially sugar-beginning to show signs of new life which it is hoped will continue till they eventually emerge triumphant.

There is, however, a very important industry carried on exclusively in this colony for which the outside world does not give Trinidad credit as it bears the name of an old Venezuelan city known as Angostura in which the now celebrated

\section{ANGOSTURA BITTERS}

was first made-I have casually mentioned it in the introductory chapter at pages 14-16. Since then I have been at considerable pains to find out more about it, knowing as I do that it plays a conspicuous part in the industries of Trinidad and contributes considerably to its revenue and importance. In that 
chapter I promised to refer to it again, I, therefore, now proceed to keep my promise. In the paragraph referred to I stated that it began to be manufactured in Trinidad a short time before my advent. In that $I$ was mistaken, it should have been a short time after. It has a very interesting history which I will now proceed to relate.

The name Angostura was given to it by its inventor, Dr. J. G. B. Siegert, after the town of Angostura where he then lived.

Dr. Siegert was a German and studied in Liegnitz in the Province of Silesia in Prussia and after completing his education served as a surgeon in the army of the then Kingdom of Prussia.

Attracted by the war for freedom in Venezuela, he embarked early in the year 1820, accompanied by several belligerent comrades-among whom were many men of great note-for the purpose of espousing the cause of the Liberator, General Simon Bolivar. The enrollment was gladly accepted by the General at Angostura, on the River Orinoco, the capital of the then Province of Guayana, where Dr. Siegert was appointed by General Bolivar, SurgeonGeneral of the military hospital of the province.

He settled in Angostura and practised as physician and surgeon until 1859, when he resigned his practice ; during the long years of which he had won the respect and esteem of his fellow-citizens and countrymen.

That Dr. Siegert was a man of great scientific attainments is evidenced by the fact that in 1838 he 
was elected a non-resident member of the Medical Society of Halberstadt, to which he had addressed many scientific essays, particularly on the subject of tropical herbs and plants, of the medicinal value of which he had made a special study.

Some years previous to this, in 1824, he first made for his own use a preparation which he called Aromatic Bitters, and which soon acquired such favour among his friends and the public that he was encouraged to devote himself to a greater extent to the preparation of this compound.

The bitters were exported for the first time in 1830, when a shipment was made to the British island of Trinidad, and to England, and from that date the actual manufacture of the article may be said to have begun. It became widely known from the place of its origin, under the name of Angostura Bitters. It is well to observe here that the name of the town of Angostura was changed in 1846 by an Act of the Venezuelan Congress to that of Ciudad Bolivar, in honour of the Liberator, Bolivar.

In the year 1853, when the sale of the bitters was still small, Carlos Siegert, Dr. Siegert's son, upon the completion of his education, returned from Europe and commenced to help his father in the manufacture of this tonic, and devoted himself with such earnestness to the business that its sale spread to all parts of the world.

Having given, by his attention and perseverance, considerable impetus to the business, his father took him into partnership in the year 1864. This part- 
nership was not, however, made public until 1867, from which year the business was continued under the firm and style of Dr. J. G. B. Siegert \& Son.

After the death of Dr. Siegert, which occurred in the year 1870, in Ciudad Bolivar, his son Carlos became the sole possessor of the right and knowledge to manufacture the Angostura Bitters, and, assisted by his brother, Alfredo, he continued the business under the old name and style until the year 1872, when admitting into partnership his brother Alfredo C. Siegert, the name of the firm was changed to Dr. J. G. B. Siegert \& Sons.

In their efforts to keep pace with the ever increasing demand for their celebrated compound, and to be able to promptly execute the orders for the article, which was a matter of impossibility in Venezuela, owing to the constant disturbances, the two brothers decided in 1875 to remove their place of residence to the British Island of Trinidad, in the West Indies, and established their Bitters Manufactory in the town of Port-of-Spain.

In 1876 they admitted into partnership their younger brother, Luis, and the business was continued under the same name and style.

In 1880 Carlos Siegert and his two brothers erected a large building exclusively for the manufacture of the Angostura Bitters. The building has since been enlarged, and now measures seventy yards front by eighty yards deep.

Luis Siegert, one of the most popular men who ever resided in Trinidad, died in June 1905, and his 
share and interest in the business and manufacture of this celebrated compound was assumed by the surviving partner, Alfredo, who admitted into partnership his nephews George and Albert Siegert, and his own son Alfredo, and the business continued under the same style and firm as heretofore.

In February, 1910, it was converted into a Limited Liability Company called "Angostura Bitters (Dr. J. G. B. Siegert \& Sons) Limited," which has continued the manufacture exactly as carried on since its first foundation in the old city of Angostura in 1834 .

All the old members of the late firm have remained with the Company and the manufacture of these celebrated Bitters has continued under their personal charge and superintendence as heretofore, and Alfredo Siegert and his son have seats on the Board of Directors.

The manufacture of the Angostura Bitters is a secret which is so carefully guarded by the Siegert partners of the firm that they personally do all the work of compounding the article, and only the work of filling the bottles and packing the cases which is done under their supervision, is performed by their employees.

Dublin is celebrated for, and has been made famous by being the place where "Guinness's Stout" is made ; and Trinidad is, year by year, becoming celebrated as being the sole place where the celebrated "Angostura Bitters" is manufactured. The name of Guinness has been made famous all the 
world over through its "Stout," and in like manner the name of Siegert is becoming known throughout the world by its unique "Bitters."

But it has, and is locally doing more than this ; by the well remunerated employment which it gives to many and contributes, year by year, to the fame of the colony and thus helping and will help to make Trinidad of Now more widely known than the Trinidad of Then.

Were I to recount the number of diplomas, medals and Royal recognitions which "Angostura Bitters" has received from many Crown Heads of Europe and distinguished personages all over the world, it might be thought that I was writing an advertisement, instead of simply endeavouring in a plain manner, to describe that which is of world wide renown and will tend to bring this colony more conspiciously before the world, when it becomes more widely known that it claims the distinction of being the sole home of its adoption.

\section{OTHFI NHW TNDUSTRIEF.}

There are, also, many other new industries started : some on a large, some on a small scale since my advent to Trinidad ; but as they are not exclusive to Trinidad-as " Angostura Bitters" is-I can only passingly refer to them. Taking them alphabetically they are as follows : Brewery, Carriage Building, Cigar and Cigarette Making, Furniture, Horticulture, Match and Soap Making and a Tannery, and though last, not least, "Electric Printery." 
A Brewery is, of course, nothing special, but it is somewhat unique in a tropical country, as almost all the ingredients and material have to be imported, thus considerably handicapping it when brought into competition with the home manufactured article; but still, notwithstanding this, I believe the "Walters Brewery " is making its way.

Carriage Building was unknown in Trinidad in my early days; repairs and cart building of a very crude nature was all that could be done ; but of late years some very fine carriages have been built at the " Gittens Carriage Factory," but I am afraid that in consequence of the number of motor carriages-over 200-lately introduced into the colony, this important minor industry is on the decline. The Trinidad Government Railway build a considerable number of their carriages and waggons and may in time be able to build all except the springs and wheels.

Cigar and Cigarette Making, carried on by Mr. Thomas Miller, is another rising industry giving employment to a goodly number, and is thus a great asset to Trinidad, but as the material used is mostly imported it is but half a Trinidad industry, still it adds to the ever increasing number of wage-earners which is an important matter.

Furniture Making is, I may say, an entirely new industry, for although furniture was, to a very limited extent, made in Trinidad it came to the front about a dozen years ago, is being enlarged year by year, and it now gives steady employment to hundreds. The locally made furniture is not 
only of a good but well finished article, equal to the best, and as the material from which it is made is of our well seasoned wood, it is more lasting and impervious to native insects than imported furniture. The chief manufacturers are Smith Brothers \& Co., (The Bonanza), Miller's Stores, Davidson \& Todd, (The Arcade), and Wilsons Limited. I pass every day by the large factory of Smith Brothers \& Co., and have been so struck with the largeness of their workshops, that I frequently stopped to look and admire the finish given to the articles made there and the soundness of the material used. It must not be thought that I specially select this firm, but as it was constantly seeing their large workshops that induced me to write the latter part of this chapter I particularly allude to them.

St. Joseph Nursery.-In glancing over a recent West Indian Circular I was reminded of a very important economic industry of late years inaugurated in Trinidad and it struck me that an account of it ought not to be omitted in this book as it forms a very important item in what is being done to bring Trinidad to the front. The paragraph to which I have alluded goes on to give a nice description of this Nursery, but as it is one of the institutions started within my time I prefer giving my plain unvarnished account of it.

It was inaugurated a few years back by $\mathrm{Mr}$. Henry Caracciolo, who, for some years previous, had taken a vivid interest in Natural History and Agri- 
culture. Since it has been established it has progressed wonderfully and a visit to this Nursery ought certainly to be made by all interested in agriculture or lovers of ornamental plants. When we consider its near proximity to Port-of-Spain it ought to form one of the attractions of visitors and tourists who flock to our island ; for there they will see many things which they never before have seen and perhaps be induced to transplant to their homes beyond the sea some plants that will be a pleasant recollection of their visit to our shores.

The economic section comprises a large stock of the major staple products of the colony such as cocoa, coffee, tonca beans, Central American and Para Rubbers, and the efforts taken to ensure healthy vigorous plants have been successful beyond expectations, which is no doubt due to the careful selection of seeds before planting. Forastero cocoa is largely cultivated and it will be remembered that this was the kind that had to be resorted to at a time when cocoa planting was again resorted to after the failure in 1756 alluded to in the chapter on cocoa. Young and vigorous plants of grafted mangoes, limes and oranges of the best varieties are obtainable, and I strongly advise any person wishing to obtain these valuable plants for their own use to pay this Nursery a visit so as to be able to make the best selection.

The decorative section consists of a large variety of palms, ferns and dracaenas and from their healthy appearance are much in evidence; two plants of a 
remarkable kind are sure to attract the notice and curiosity of visitors, I allude to a large fern-tree and a variegated orange. There are many others whose names I forgot, even if I ever knew them.

Visitors from either the colony or abroad who order plants of either an economic or ornamental kind to be sent to their homes may rely on receiving them in as perfect order as they were on the day of selection. There will also be found many varieties of hardy timber plants consisting of cedar, Honduras mahogany, cyp, poui and other well recognised decorative and furniture-making timbers, which will be profitable if planted along the cocoa traces.

It would be impossible to give here anything more than a sketch of this fine Nursery, it must be seen to be thoroughly understood and fully appreciated ; it would be well if the proprietor would publish a full descriptive catalogue of all that is to be seen and disposed of.

I am sorry that space will not permit me to give a fuller description of this new and thriving industry which certainly deserves the patronage of not only our own people but also of our visitors ; it is, I believe, the only Nursery of the sort to be found in any of the British West Indian Islands.

I need not say more, for visitors to this Nursery will be able to receive all information they desire from either the proprietor or his manager on the spot. I wish it the success which it deserves, and hope to see it at no distant day forming another and strong contrast with the Trinidad of Then and Now. 
Match Making is also a comparatively new industry ; it gives a limited employment but is sadly handicapped by having to compete with matches imported free of duty. Soap making is carried on in the same establishment.

The Tannery is not a very large industry, but as it uses up the hides of the animals killed in Trinidad and supplies a good deal of leather used for various purposes in Trinidad it is deserving of notice.

Now comes the last, but by no means the least, of this colony's new industries-because it is a new industry as delineated-I allude to the art of Electric Printing and Linotyping. When I came to Trinidad, I am of the opinion that neither were heard of in any part of the world, and so much is Trinidad up-to-date that we now have both. If I wanted an argument to illustrate my meaning, I could not find a better one than is evidenced by the printing of this book which you, my gentle reader, are now perusing. The press on which it is printed is run by electric power, and the textual matter is linotyped. Is it not a fair illustration of what can now be turned out in Trinidad ? The binding is also done in the same establishment and, although it may not be compared with the best in England yet it compares favourably with such work even in Great Britain, and both tend to show the vast difference there is in this respect between the Trinidad of Then and the Trinidad of Now. 


\section{CHAPTER XVII.}

PUBLIC INSTITUTIONS.

The public institutions of Trinidad are numerous, but fortunately only a few are dependent on charitable contributions, the majority being supported by the Government. Of these so supported I can only spare space to say a few words about

\section{The Colonial Hospital.}

When I came to this colony there were two branches of this noble institution in the colony. I have called it noble, for what can be more noble than an institution solely devoted to the relief of suffering humanity. The chief hospital was in Port-of-Spain with a branch in San Fernando ; there are now six, viz : the two named, and St. Joseph, Tacarigua, Arima and Princestown, with, I believe, a small ward in Mayaro for urgent cases. These are exclusively government institutions maintained out of the revenue of the colony.

Port-of-Spain being the chief, I will choose it to illustrate this sketch. When I came to Trinidad it was in full swing, presided over by the SurgeonGeneral, a Resident and an Assistant Surgeon ; the resident, as the term implies, resided within the precincts, and the assistant, then a married man, for whom no quarters were provided lived outside, about a quarter of a mile away. The hospital was not 
then so large as it is now, many wards having been added and also quarters for the assistant surgeons, so that all the medical staff, except the Surgeon-General, now reside within the precincts. The whole institution has vastly improved ; but it was not Then as it Now is a credit to the colony.

I think what I have already written will show that I am not desirous of saying harsh things about persons or institutions; but if I am to show the strides made, truth compels me, now and then, to show what they were, otherwise I would not be able to show the contrast between Then and Now nor show the vast improvements made. The following narrative will describe the Then state of the Colonial Hospital in Port-of-Spain.

In passing along St. Ann's road (now Charlotte Street) one must be struck by the fine. outward appearance of this building and its well kept grounds, which from the first was, and to the present is a credit to the colony. My first acquaintanee with its internal arrangements occurred in this way, and the story I have to tell will not reflect much credit on either its discipline or arrangement at that time.

One Saturday, either in February or March, 1875, having finished my office work I strolled up to the Savannah with the intention of ending my walk in the Botanic Gardens, then kept in a better state than they now are-although they are beginning to improve. Having entered the Savannah I sat down on the stump of a tree and while so sitting a number of school boys entered, evidently bent on playing 
" the noble game of cricket," or what some of our celebrated cricketers would now contemptuously designate " bat and ball." A poor old East Indian, commonly called "a coolie," was driving a cow to his employer's residence and these young mischief-makers began to pelt him with soft lumps of earth, which naturally annoyed him ; he ran after and caught one who, without a moment's hesitation struck the old man on the top of the head with a wicket, felled him to the ground and immediately ran away. I went in pursuit, but the boy got too much start and I returned to the old man to see his state. I found him senseless, with a bleeding wound on the top of the head, and immediately had him conveyed to the hospital not far from the Savannah.

IIaving safely conveyed him there I looked about for some one to attend to him, and after some minutes had elapsed, a young practising dispenser leisurely strolled up. I said, "Here is a man in a dangerous condition, please have him attended to." "Leave him there" was the reply, "I will send for the assistant surgeon, he has just gone home to his tea." Being well acquainted with what obtained elsewhere, I asked, " have you no resident surgeon on the premises? "Yes," he replied, " but it is not his turn for duty." " No matter," I said, " call him, when he hears of the serious nature of the case he will surely come." " No," he replied, " he must remain till the assistant surgeon comes, I have sent for him." "Have you no dresser ?" I asked, "who in the mean time could attend to his wound ?" 
"What is a dresser ?" he asked, "I don't know of any," he must remain as he is till the doctor comes, he cannot be admitted without the doctor first seeing him." Then get someone to sit with him till the doctor comes." "No," he replied, "you must remain with him and look after him, we cannot have anything to do with him till the doctor comes." I did not remain with him, but instead went in search of the boy whose name and residence I had obtained on my way to the hospital. I returned in about an hour and entered the gate the same time as the assistant surgeon and told him of the case.

When he arrived at the door of the dispensary, the old man was nowhere to be seen and the doctor was very indignant with the dispenser, who pretended to know nothing whatever of the case-his assistant having disappeared; search was made for the old man and he was found lying senseless in his employer's yard, and on examination it was found that not only had he received a serious wound but also that his skull was fractured.

I need not relate all that followed on this case, suffice it to say that one of the results was the building of the quarters now occupied by the assistant surgeons and an additional assistant immediately appointed. I need not say that similar indifferent treatment to any patient, much less a wounded one, brought to this institution could not Now occur.

I could tell an amusing story in connection with the arrest of the boy who inflicted the wound, but perhaps a wealthy merchant now having more pounds 
to his name than I have pence, who was himself but a boy in those remote days might not like it, so I will let it pass ; I know he remembers it for it was only a few months since he and I were speaking of it. Don't think that it was he who wounded the old man ; it wasn't.

There is still one drawback to the successful working of this noble institution, for which neither the government nor Surgeon-General are responsible. It is the lack of a charitable fund, voluntarily contributed, by which deserving poor when discharged from hospital would receive some temporary help, for believe me many are deserving of, and much in need of it. Cannot some charitable ladies be found to take it up, the details can easily be arranged ? I simply throw out the idea.

Coincidences are curious things. This chapter was in the hands of the printer on August 1st ; on the 8 th, I received the first and on the 17 th the second proof ; on the same day I accidentally came across an old copy of the Port-of-Spain Gazette dated June 17th, 1834, containing a report of a meeting of 32 ladies presided over by Lady Hill, (the Governor's wife,) containing many names still familiarly known in Trinidad, held with a somewhat similar object to what I have suggested. Space will not permit me to give it in extenso but the first rule is :-

"First. The object of the society shall be to relieve the industrious poor and indigent sick."

I think this must have been before the present Colonial Hospital was established, but the object 
although having a much larger scope, than that which I suggest, was, as will be seen, "for the relief of the Indigent sick." A poor sick person discharged from hospital cured if he has not the wherewithal to keep him till he can obtain employment is very likely to become a permanent burden on the colony.

I will next introduce to the favourable consideration of the public and visitors

The Trinidad Hone Industries Asgoctation.

There is no institution in Trinidad which deserves greater support and patronage than that which is known by the name of "Trinidad Home Industries Association." So keenly do I feel this that I take the liberty of devoting a space, though necessarily a short one, to this noble institution, "whose object is to assist home and cottage industries, so as to enable gentlewomen who are in reduced circumstances to add to an otherwise small income by selling work, and also for the relief of distressed working women."

This institution was inaugurated in the early part of 1901 by Lady Moloney-who although not with us is still revered-in concert with many ladies of the community who generously joined in helping this noble enterprise ; Lady Moloney thus became the first president. From an able report drawn up by Mr. Alfred Taitt, who was then Honorary Secretary and Treasurer of the Association, I have been able to ascertain that the number of patrons at its first foundation, consisted of 60 , and of Associates 250, with a Management Committee of 25 . 
These original members have been sadly reduced either by the hand of death or by being unavoidably compelled to sever their connection with the colony, but while with us they all gratuitously and generously devoted a good deal of their time and energy to its superintendence and support, which must always be gratefully remembered by those who have benefitted by it, thus the memory of those who have passed beyond the bourne will, I trust, be always revered, for although as time passes vacancies must bers, yet this will not efface the memory of those who be, and have been, filled up by ever increasing numfirst worked hard to establish it.

While on this point I cannot refrain from giving a special meed of praise to the lady who so long acted as treasurer, but who, a few days before these lines were penned, passed away deeply mourned by her sorrowing husband, near relatives, and many others whom her benevolence befriended; deeply regretted by all both rich and poor; even by those whose acquaintance with her was but casual. Many passages in the letter of King Lemuel's mother addressed to him in "the praise and properties of a good wife," and, let me add, good woman, can with truth be applied to her. I will, however, quote only two, merely slightly changing the phraseology, they are as follows :-

"She stretched out her hand to the poor; yea she reached out her hand to the needy."

"Many daughters have done virtuously, but thou hast excelled them all." 
When this institute was first founded it was dif. ficult to obtain a suitable place in which to establish it, as rents in Port-of-Spain being high it was beyond their means to rent one, so a portion of the Victoria Institute had to be occupied as a temporary measure, but when it began to look up a more suitable one was found for it in Frederick St., the centre of commerce. It was removed there where the display and sale of needle work and other home industries is carried on, where every effort is made to increase its associates and promote the disposal of useful and suitable articles, many of which could not be procured in other places.

To this has been added an up-to-date light refreshment room where breakfast, tea, cakes and, later, ice creams, etc., are supplied at a moderate cost ; it is largely patronized, serving as a great boon to tired country visitors, officials, merchants and other business men before seeking rest in their country or suburban homes or undertaking a long railway journey to more remote parts. It is also a welcome diversion to tired tourists who, wandering through the town either seeing the sights or making purchases, or both, desire a little rest and a refreshing cup of tea-none better can be obtained elsewhere, even in your homes.

Of late there has been added a collection of curios, or such articles as are not to be found in other climes, although common enough in Trinidad which are, therefore, looked upon as curious objects by travellers who avidly purchase them. 
Shortly after this institution was started it was put to a severe test. The frightful calamities of the 6 th May, 1902 by which the islands of Martinique and St. Vincent were devastated and the town of St. Pierre in Martinique was wiped out of existence at one fell swoop by the eruption of Mount Pelée, where every living soul in that ill-fated town-except one, and he a prisoner in gaol-perished and the surrounding country together with the neighbouring island of St. Vincent-whose Soufriere Mountain also burst into eruption-was almost denuded and their inhabitants brought to the verge of starvation. These dreadful visitations called forth the benevolence of the patrons of this young and struggling "Home Industries Association " and they courageously and generously helped both islands by money, and the work of their hands-which was more precious still,-to relieve many of the sufferers. The ladies of this institution rose nobly to the call upon their time and industry; they worked willingly and many poor destitute women, refugees from these islands, had cause to bless them ; but memory of kind deeds ungrudgingly and unsparingly rendered is often short-lived, let us hope it was not so in these cases.

This deserving institution is now in a fairly flourishing condition; its associates have increased, and it now employs four ladies of good education, courteous and pleasing manners, address and obliging disposition, one as manager and the others as assistants, all of whom are engaged in attending to the wants of its patrons by exhibiting and disposing of 
the articles entrusted to their care ; it is open on week days from 8 a.m. to 4 p.m.

One of the first objects of the assistants after enrolling those who wish to become members is to impress on them the desirability, in fact the necessity of sending to the sale room only good saleable articles, and that all needle work should be executed with the best material, because, beautiful work such as is expected from and is sold at this institution, ought not be depreciated by the employment of inferior material in its construction, if this be doneand I believe it now is-strangers and our own people purchasing will be able to recommend the work of this institution to their friends across the sea and be the means of attracting many orders from abroad.

I remember an incident which once occurred in my hearing there during one of the busy tourist seasons. A number of purchasers were patronising it, some purchasing very generously. A lady and a gentleman-I apply the term in the real not the conventional sense--evidently husband and wife, were large purchasers, or rather the lady was. When she had completed them, she in a wondering undertone, addressed her husband thus :- "Why these attendants are real gentlewomen." Yes, my dear madam, they were, are, and I believe always have been "real gentlewomen." You unconsciously conferred a well deserved compliment Then; but you will also confer a great favour on this worthy institution Now by extolling its merits and recommending it to the patronage of such intending visitors to our beauteous 
clime as you may know ; nothing will give us greater pleasure than to welcome you and them amongst us, hoping that you and they will then as generously patronise this deserving institution as you did when you previously visited us, and that you will carry away with you many souvenirs and pleasant recollections of what you have seen and enjoyed in Trinidad Then and Now, for as Dryden sings :-

\section{"Kindness by secret sympathy is tied,}

For noble souls in nature are allied."

There is another association in Trinidad which, although not run on strictly philanthropic lines, as compared with those named, has, nevertheless, done a considerable amount of good. 'I allude to the

\section{Trinidad Building and Loan Association.}

This Association was started in 1891 with the double object of enabling small capitalists to invest their savings in a sound undertaking, with the object not only of giving them a reasonable amount of interest on their small investments but also enabling themselves, friends, and others to acquire their own residences on easy terms. It is therefore in this respect alone that it can be considered as philanthropic, for it can hardly be said that any undertaking in which $8 \%$ interest is made is purely philanthropic. The following rule speaks for itself.

3. "The objects of the Association are to accumulate a fund for the purchase and improvement of Real Estate or of leasehold properties, of which the unexpired term shall not be less than twenty-five years ; to make advances to its members on the secu- 
rity of unencumbered Real Estate owned by them, or of unencumbered leaseholds of not less than twentyfive years, or on Mortgage securities on Real Estate or leaseholds as above stated, held by them, or on the security of their unadvanced Shares or of their Debenture Bonds, or to aid them in acquiring Real Estate or leaseholds as above stated, making improvements thereon, or removing incumbrances therefrom; and to accumulate a fund to be returned to its mem-i bers as hereinafter provided."

This Association has done an immense amount of good and Trinidad has every reason to be proud of it. The names of the Managing Committee and Secretary consisting as it does of such well-known citizens as :-Messrs. J. A. Rapsey, Hugo Hoffmann, Adam Smith, A. O. Rudin, H. K. Stone, H. W. Brathwaite, John William McCarthy and C. E. Drayton, with A. F. Mathison as Secretary and Treasurer, must serve as a guarantee of its bona fides, and the number of years which it has continued to be in flourishing existence is, or ought to be, ample prowf that it is an association not only to be relied on but also encouraged. In my opinion it is worthy of being used as an illustration of the difference between the Trinidad of Then and the Trinidad of Now.

I, therefore, am pleased to be able to accord it a deserving meed of praise in the pages of this book and I hope be the means of bringing it into more prominent notice. 


\section{CHAPTER XVIII.}

THE POLICE AND THE PUBLIC.

Max O'Rell, the humorous French writer, was once asked why he never wrote anything about the Irish. The reason for this question is apparent to anyone who has read his sketches on the characteristies of "John Bull and His Isle," " John Bull and His Women Kind," "Friend MeDonnel," and "Our American Cousins," in each of which he touches off the separate foibles of each nationality. His answer to the query about the Irish was :- "I I have often tried to do so, but I find that Irishmen's failings are all virtues." So in like manner I have been asked to write something about the Police Force with which I was so long associated, having served in various ranks close upon the verge of 50 years, an almost unprecedented service. It therefore follows that I would not be an unbiased writer; but although I cannot say their failings are virtues, yet, I will say that they are not worse than any other body of men, and were my verdict asked I would honestly say that their good points far outweigh their weak ones. This being so, were I to give a variety of my personal experience in these matters I might be accused of strong bias. I therefore prefer to let another speak of them as they were in his day, simply 
adding, I thoroughly agree with every word he wrote, whether of the Police or the Public.

It will be remembered that in a previous chapter I alluded to Mr. Lovesy, at that time, one of the Judges of the Supreme Court of British Guiana, but formerly a Stipendiary Justice of the Peace in Portof-Spain, which brought him in daily contact with the police to whom, before his promotion to Demerara, he wrote the following reply to an address from them :-

"My friends,

"Your address has afforded me the greatest and most sincere satisfaction. It not only assures me of the good will you bear towards my family and myself, which I prize highly, but affords me an opportunity of observation upon a subject concerning which I have sometimes found it difficult to be silent.

I alluale to the absurd and mischievous cry which has from time to time prevailed since I have been in this colony of "the inefficiency of the police." This is a matter upon which I should be able to say something, and now that I have a chance, I will say it. I found you on my arrival a much more efficient body of men than I had been led to expect, (having heard something of you during my voyage hither), and I am sure that you have very far from deteriorated during the two years we have worked together. But I by no means say that you are perfect, any more than I am perfect myself. A thoroughly efficient magistrate should be the equal 
of the Lord Chief Justice of England, the chief of magistrates.

A thoroughly efficient policeman should be a fair scholar and a competent criminal lawyer; he should possess a far greater share of the wisdom and tact of Solomon and the patience of Job than usually falls to the lot of mortals ; to which should be added the bodily strength, endurance and constitution of a prize-fighter. How long a man thus gifted would think it worth his while to remain a member of any Police Force, I need scarcely stop to enquire.

The fact is that by far the greater portion of the world's work is done by imperfect instruments. Perfect instruments, whether human or otherwise, are somewhat scarce, and if nothing worse than the best be employed, I fear but little of that work would be done.

The publication of a pamphlet purporting to be a report of the proceedings at a recent public meeting, in the course of which you came in for your share of censure, affords me substantial basis for remark. "The most atrocious murders" it is said, " such as London detectives, would trace at once, are here committed with impunity." I incline to the opinion that this ugly fact is due rather to the shortcomings of Trinidad Jurymen than of the Trinidad Policemen, and I will add that I am not myself disposed to believe altogether in the omniscience even of London detectives.

There are many grim secrets, both of old and very recent date, which have effectually baffled this 
useful body of men, and which will, I fear, remain secrets until doomsday. Next, it is alleged against you that "robberies of every description are frequent but their detection the exception and not the rule;" and "that prostitution, drunkenness and profligacy parade themselves in the broad light of day throughout this city, unnoticed, unpunished and unchecked."

I think there are at the present time under the charge of my friend the superintendent of the gaol some who could tell a different tale. Lastly, your inefficiency at the recent calamitous fire is urged against you. I think it probable that there is some foundation for this charge at all events. No two bodies of men differ more completely in their drill, training and organization than firemen and policemen ; and it may be that you failed for the same reason that a tailor would fail in an attempt to make a horse shoe, or a farrier who tried his hand upon a dress coat. When the next fire happens, I trust that both the newly constituted fire brigade (who have my best wishes), and the police will be found equal to their respective duties.

But it may be that some of your detractors base their opinions upon the fact that the more serious class of crimes, such as larceny, embezzlement, false pretences, etc., so frequently escape detection ; in this town in particular. There I must myself assume the character of complainant. I protest in turn against the "inefficiency" of prosecutors, who having set the law in motion will not be at the trouble of 
subsequently appearing to substantiate their charges. Since the comparatively short time I have held office in this colony, I do not say that scores, but I say deliberately that hundreds of criminals have thus been enabled to set the law at defiance.

In conclusion, I bid you remember this to your comfort-that every official from a Prime Minister downwards must expect censure. It is a weapon as readily wielded by a fool as by a wise man, and is generally to be found in the hands of the former. But there is a way by which you may render censure, by whomsoever aimed, pointless. Be sober, faithful and diligent, do your duty honestly according to the light that is in you, and fear God. He who acts thus need fear no man.

I bid you heartily farewell,

\section{W. LOVESY.}

There are two parts of this letter which I will ask permission to re-quote as being equally applicable to the present day, the first is :-

"I incline to the opinion that this ugly fact is due rather to the shortcomings of Trinidad Jurymen than of Trinidad Policemen." In this respect I also assert Trinidad has not improved. It must be remembered that this strong observation was made by a man of ability and strong sound judgment. There are no men who have better means of knowing the merits of cases which they have taken the trouble from day to day to thoroughly sift and separate the chaff from the wheat than the Sti- 
pendiary Justices who take the preliminary depositions in each case before returning it for trial to a higher court, and I must bear this testimony to the pains-with few exceptions-taken by them and therefore Mr. Lovesy, and magistrates who have come after him, have been unanimous in passing these strong strictures on the Jurors of Trinidad, and in this respect I am sorry to say Trinidad is in as bad a state Now as it was Then.

Trial by jury was first introduced into Trinidad in 1844. Before that date the system of trial was regulated by an order in Council bearing date the 20th June, 1831 and was as follows. In all criminal trials before three judges and three assessors, the latter were chosen from the members of the Cabildo of the Town of Port-of-Spain to deliberate and vote with the judges upon the final judgment to be pronounced in every criminal case, and the verdict was to be the verdict of the majority.

That trial by Assessors was not desirable is fully illustrated by a scene which occurred at a Criminal trial on the 1st May 1832, when the two Assessors, the Alcaldes, appointed to sit with the judge refused to do so, with the result that the sessions were abortive. The judge was Chief Justice Scotland and Sir Lewis Grant was the Governor at the time. A full account of it may be read in the Port-of-Spain Gazette of the 23rd and 30th May, 1832. This failure of enforcing the law led to the Order in Council of the 15th August 1832, and eventually to our present jury system. 
On the 15th August, 1832, another Order in Council was made admitting to the discharge of the duties of Assessors all free adult male inhabitants who possessed certain qualifications. This continued down to the 2nd September 1844, when an Ordinance -11 of 1844 -was passed establishing trial by jury, which continued down to March, 1848, when it was amended to that which now forms the main features of our present jury system.

The other passage which I will quote from Mr. Lovesy's address-speaking of unpunished (mind you, not undetected) crimes, he says :-

"Here I must myself assume the character of complainant. I protest in turn against the 'inefficiency' of prosecutors who having put the law in motion will not be at the trouble of subsequently appearing to substantiate their charges." Is this not the case in the present day ? Merchants are afraid that by their absence from their stores for even a few hours they may lose more than the paltry few shillings, or shillings' worth, which their clerks or shop assistants have stolen or embezzled. Believe this, that so long as you are indifferent you may also find an indifferent police. The fault is yours; the remedy lies in your own hands. Many trials of criminals for various offences, particularly murder, have been rendered abortive through the extra timidity or want of proper reasoning powers of our jurors ; I have even heard it called by a harsher name, and then the failure of detection and increase of crime is laid at the door of the Police. To 
jurors, I say do your duty and you may rely upon it that the Police will do theirs. I remember the time when the Police were almost in dread-in consequence of the abuse they received-of bringing any criminal to justice. Happily this is changed but unfortunately the temerity of jurors, or, call it by what other name you will, is still the same, in fact, I am almost inclined to say that in this respect Trinidad has not only not improved but that it is worse Now than it was Then.

Amongst the many assertions made by jurors and others against the police is "he exaggerated the case so as to gain the praise of his superiors." My dear critic, you don't know what you are talking about; how do you know that success invariably, gains the praise of superiors? In some cases it no doubt does but in many others it has the reverse effect. Did you ever hear of a malady called jealousy? If you did, then in no place is it more frequently displayed than by superiors in Police Forces towards inferiors who are successful in the detection of crime; the superior often looks upon it as a reflection upon his inferior intelligence and many cannot bear to hear a word of commendation spoken in favour of a subordinate. I who know it, assert it, it is not always pleasant to be more clever than your quasi superior.

There is also a tendency in every community to underrate the importance of the police, and every place where there is a police force, this, so far as the 
Trinidad Police Force was, and I say is, included is fully exemplified in Mr. Lovesy's address.

Sir Conan Doyle writing of what he calls the

Heroism of the Police.

says :-

"It takes courage to plunge into the boiling surf and to carry the rope to the breaking vessel. It takes courage to spring from the ship's side and support the struggling swimmer, and never know the moment at which a flickering shadow may appear in the deep green water, and the tiger of the deep turn the white belly upwards as it dashes at his prey. There is courage in the infantry man who takes a sturdy grip of his rifle and plants his feet firmly as he sees the lancers sweeping down on his comrades and himself. There is courage in the soldier who in retreat sees a wounded comrade left behind, whose fate, if left there, would be certain death, rushes to his rescue and bears him aloft into safety.

"But with all these types of bravery there is none to compare with that of the homely constable when he finds on a dark tempestuous night that a door on his beat is ajar, and listening below, learns that the time has come to show the manhood that is in him. He must be prepared to fight odds in the dark. He must single-handed, cage up desperate men like rats in a hole. He must oppose his simple weapon to the six-shooter and the life-preserver-life destroyer would be more appropriate. All these thoughts, and the remembrance of his wife and chil- 
dren at home, and of how easy it would be not to observe the open door, comes upon him and then what does he do? Why, with that thought of duty in his heart and his little cudgel in his hand he goes to what may be certain death-with no one looking on to record his valiant deed-like a valiant high-minded man who fears the reproach of his conscience more than the pistol bullet, or bludgeon stroke."

There I would leave it, I would not spoil it by one word of comment were it not that some of the would be detractors of the Trinidad Police would like to say, but this grand encomium does not apply to them. Does it not? wait and hear. I have said elsewhere that before coming to Trinidad I served in Belfast and went through two of the biggest riots that have ever occurred there; one of which lasted for three weeks and took 13,000 armed troops and police to suppress, and I positively assert that I have never seen greater bravery than was displayed by the Trinidad Police on the night of the far-famed Cannes Brulee riot of the morning of of the 22nd February, 1881.

Although the comments made in this chapter apply with equal truth, to the Police and the Public in various parts of the Kingdom, yet as it is to Trinidad that I intended it to apply, I think it right, contrasting a previous long and varied experience elsewhere, to bear testimony to the good and lawabiding character of the inhabitants. This includes not only the natives but also the various nationalities residing here. 


\section{CHAPTER XIX.}

WIRE AND WIRELESS COMMUNICATION.

When Cadmus in the remote ages of the world invented the alphabet I wonder did he for a moment conceive the wonderful revolution he was making, whereby one nation, as time advanced, would be able to communicate its thoughts, actions and knowledge to the remotest parts, thereby establishing a link between all nations, kindreds and tongues which has never since been broken.

In like manner the telegraph, the telephone, and the Marconi have each in their turn revolutionized the world, and Trinidad, although a very small place, has not been behind with any of these new and useful institutions.

When I came to Trinidad there was a limited telegraph system here ; you could, it is true, Then as Now, send a message to all parts of the world, so that when I speak of limited I mean limited so far as communication within the colony was concerned, then you could only send a message from Port-of-Spain to San Fernando. This defect was remedied when the railway was made ; it established a system of telegraphy to all parts of the colony, wherever the railway extended, and you can now send a message to any place within easy reach of any railway station. 
The telephone is of more recent date, but when it once began to obtain favour elsewhere Trinidad would not be behind hand and at once had it established here ; it dates back to the early eighties.

It was at first confined to Port-of-Spain but later extended to San Fernando, and, later still, to other country districts. With regard to the introduction of the telephone, or rather after its introduction and completion, a good story, for the truth of which I can vouch, can be told. Although, strictly speaking it has nothing to do with the Trinidad telephone, it has a good deal to do with the gentleman, a Mr. Gray, who superintended its erection. A Mr. Fitzgerald got a kind of concession and formed a company to erect a telephone system in Port-of-Spain ; its erection was entrusted to a Mr. Gray, an Englishman, who, when he had finished here, went elsewhere to erect others. It seemed that in the course of his travels, he found himself in one of the South American Republics and there obtained the promise of a concession giving him the sole right to erect a telephone system there. While on his way to England, to float a company, he touched at Barbados, awaiting the Royal Mail steamer homeward bound. Here I leave him for the present, in order to introduce a man, who, afterwards assumed the role of principal actor in the comedy which follows.

There was in the land of Trinidad a man whose name was-but, there, no matter what his name was, we will call him the man without a name. At the time of the opening of the comedy, in which he played 
so conspicuous a part, he was in Barbados, having just landed from Trinidad; here he met Gray. In order to appreciate the comedy which follows, I must take the man without a name back for a short time to Trinidad.

He had formerly been a commissioned officer in the army, and, I have been informed that before reaching these shores he had tried his fortunes for a short time in Demerara, and, for some reason, not finding that climate congenial to him, he resolved to try his fortunes in Trinidad. Here he attached himself to a sugar plantation as an overseer. He was a man of good education, pleasing address and striking presence ; why he left the army never transpired, nor does it matter much. I am sure he would have made a good comedy actor if he could have kept honest and kept from " doing " his brother actors. I must however, without further remarks, begin to tell my story about him and what befel him in Trinidad.

He had, as I have said, been an officer in the army and on the strength of it soon made the acquaintance of the three officers who were then stationed here with a small contingent from the regiment whose head-quarters was at Barbados. He had swindled a good many of the trusting folk with whom he came in contact and among them his late employer; he was beginning to become a nuisance, but on account of his agreeable manners, and, I think also, being ashamed to acknowledge having being so easily swindled by an utter stranger, the victims would not appear to prosecute him. At length the pitcher went to the well 
once too often; he swindled one of the officers with whom he was so intimate at the garrison. This officer reported it to me and I prevailed on him to allow me to prosecute. He did so and the upshot was that the man without a name was convicted and sentenced to six months hard labour ; during which time he enjoyed the hospitality of the government under the care of Mr. Harley, the superintendent of Her Majesty's Royal Gaol. The honour of sending him there fell to Mr. Mayne who was then S. J. P. of Portof-Spain. I mention these two names because they were afterwards claimed by our adventurer as intimate friends and social equals. When released from gaol he went to Barbados.

On his arrival there he was not long in getting an introduction to Colonel Clements, the head of the police. Here it was that he met Gray. Colonel Clements had asked both of them to dine with him. He must have soon spotted Gray as a probable victim. Be this as it may, he was not long in gathering many facts about the telephone which Gray had recently erected in Port-of-Spain, and he informed him that he had just come from there. Gray asked him "Did you know Garcia ? or Mayne ? or Harley? or Baker ? etc." Oh ! yes he knew them all intimately. He did not think much of Mayne, he was a pigheaded, bumptious, dogmatic prig; there was no use trying to argue or reason with him, he doggedly stuck to his opinions-this alluded to his inability to convince Mayne of his innocence. Harley was a good fellow, he liked him very much, he frequently 
was his guest. Baker was a good natured simple fellow, not possessed of much brains-and, he was afraid, easily imposed upon. Garcia was clever, he had instructed him to find a safe investment for a few thousand pounds which he had lying idle at home, for which he had no immediate use. Then addressing Colonel Clements he informed him that " $6 \%$ and $8 \%$ can be obtained on mortgage on cocoa estates, a good security, in Trinidad, perfectly safe,' and as he had a few thousand at home he had written for it and would get Garcia to invest it for him. He freely canvassed Gray's friends, and so the conversation went on from one subject to another till they opened up the subject of the promised concession and the name of the South American Republic. Gray incautiously let out that the papers in connection with it were not yet signed and he was on his way to England to float a company. The man withont a name listened with close attention to all that Gray said about the contemplated telephone, where he intended to begin, etc., and showed such an intelligent interest in all connected with the matter, that Gray, finding such an attentive listener, felt flastered, and his tongue being somewhat loosed, as is frequently the case with men who have dined well, divulged everything in connection with the concession. The party separated in due course and on the following morning our brave adventurer presented himself to Colonel Clements with what purported to be a telegram in his hand, he did not, however, allow Colonel Clements to see its contents, saying "I have just received this 
from Trinidad telling me that there is a draft there awaiting me ; I want you to lend me two hundred dollars till I go down to receive it." The Colonel never doubting the bona fides of the man, his over night guest, advanced the money and our bold ad venturer took passage by a West Indian and Pacific steamer then in Barbados harbour bound for Trinidad and South American ports.

It is needless to say that he did not land in Trinidad, the scene of his former exploits, but continued his way to the port that would bring him nearest to the Republic where the concession was to be obtained. He arrived there in due course, stated that he was Gray's representative, had the concession made out in due form with his name inserted, and calmly awaited events. In due course Gray, having succeeded in floating his company, also arrived and was met by the man without a name who cordially received him and, in due course disclosed the fact that he had obtained the concession and then offered to make it over to Gray for a consideration. Gray was indignant but "knowing, or being informed of the uncertainty of the word of many of the high officials connected with this Government wisely consented to the demands of this clever schemer and eventually compromised with him for twelve thousand dollars, whether American or of the Republic I am unable to say, there is sometimes a big difference.

In the mean time Colonel Clements began to feel uneasy about his loan, communicated with the police 
in Trinidad with the result that he was furnished with a photograph of the borrower and an account of his doings while here. It was then, Colonel Clements having written to Captain Baker his part in the above narrative, that I learned the portion of it relating to him.

Some time after this, I think in the course of the year, Gray returned to Trinidad to have his claim on the Trinidad Telephone Company adjusted and meeting with some difficulty was advised by his friends here to start an opposition Company, which he did with the result that he got many supporters and the first company fearing a rival came to terms with him. It was while Gray was here doing this that he told to Garcia and myself, the remainder of the story which we had not heard from Colonel Clements.

There was, in the days I allude to no more easily gulled people than the people of Trinidad. If you were a clever adventurer, all you had to do was to wear a signet ring with a crest belonging to some good family, be well dressed, have a good address and pleasant manners, if you could sing a good song so much the better and there you were; you were put up in the club, where you mixed with pleasant people, and being pleasant and agreeable you were invited to their house and consequently were able to obtain unlimited credit. The man without a name was one of this sort and lived on the acquaintance he thus made for nearly a year.

I may be told that this sketch of a clever adventurer has nothing to do with the Trinidad telephone. 
Very little, I admit, but it certainly relates an amusing incident arising out of it and thus adorns a tale. I have, as I write, the photo of the man without a name before me, and when I remember the number of people he "put in" I am amused, especially as many of them often sailed pretty close to the wind themselves.

I am afraid that this is not alone applicable to the days I have alluded to. I think it has descended to our own times. I am every day hearing of a case in which many people in this fair isle have recently been gulled by a clever adventurer, who by some occult means-or was it palmistry ?-got admitted into the best society in Trinidad.

The question may well be asked why was this sound project, a project which at one time payed a dividend of $14 \%$, ever allowed to pass into the hands of a company, the majority of whom are foreigners? - I use the term as apart from Trinidadians-or still further ; why did not the Government take it over ? I am unable to answer either question except that so far as some monied individuals were concerned they, perhaps, thought that $14 \%$ interest was too small a sum for their money; they preferred going about through the town seeking whom they could devour, in the shape of impecunious goverment officials or other unfortunates, who for the time being become embarrased and from whom they were able to extract 80 or $100 \%$ at little outlay or expense to themselves, not even paying rent for an office in which to transact their business, or a clerk to do their work, the loan being, in the first instance, negotiated in the street 
or while travelling in a tram car, and afterwards completed in the store or office of an obliging friend. Is this an imaginary picture ? are there not many who will recognise the individuals who sat for the portrait; if you don't know them, look well in the highest seat of honour in their respective places of worship and there you will be sure to find them.

I do not for one moment mean to convey the idea that the telephone is not well managed ; because it is, and it, of late years, renders efficient service; but I do assert that it ought to be, as the Post Office and Railway are, under government control and any profit made out of it-and this is considerable-would go to help the revenue of the colony, and could, at a cheaper rate than at present, be made more useful to the general public.

Any way it is as it is ; it is an institution which, like " the letters Cadmus gave," could not now be done without.

I finish this chapter by recording the further progress of the colony by the latest scientific appliance of communication by wire by the introduction of the latest known addition to telegraphic science, the wireless (?) telegraph, connecting this colony with Tobago on the northern side and Demerara on the southern. It is probable it will, within measurable distance, be connected by this means with other parts of the world as well, thus bringing this colony up-todate in this respect as it is in most others, forming a great contrast with the Trinidad of Then with the Trinidad of Now. 


\section{CHAPTPR XX.}

CACAO.

On writing a chapter on the product which is familiarly called Cocoa, it may interest some of my readers to give as an introduction a few passages copied from that very interesting work "The History of the West Indies " by Bryan Edwards, written in 1794, before Trinidad became a British possession. It is as follows :-

"The Cacao or chocolate nut, a production equally delicate, wholesome and nutritious, is a native of South America, and is said to have been originally conveyed to Hispaniola from some of the provinces of New Spain ; where besides affording to the natives an article of nourishment, it served the purpose of money; and was used by them as a medium of barter ; one hundred and fifty of the nuts being considered of much the same value as a ryal by the Spaniards. From this circumstance it seems probable, that if the ancient inhabitants of South America were emigrants from Europe or Asia, they must have detatched themselves at an early period, before metals were converted into coin, or from some society which had made but moderate advance in civilization." ......... 
"It is obnoxious to blights, and shrinks from the first appearance of drought. It has happened that the greatest part of a whole plantation of cacao trees have perished in a single night, without any visible cause. Circumstances of this nature in early times, gave rise to many superstitious notions concerning this tree, and, among others, the appearance of a comet was always considered as fatal to the cocoa plantations.".........

Abbé Raynal makes the same or a similar statement.

"Blome, who published a short account of Jamaica in 1672, speaks of cocoa as being at that time one of the chief articles of export. "There are," he says, "in this island, at this time about fifty cocoa plantations and many more now planting." At present I believe there is not a single cacao plantation from one end of Jamaica to the other. A few scattered trees, here and there, are all that remain of those flourishing and beautiful groves which were once the pride and boast of the country.

"At present the only cacao plantations of any account, in our colonies, are Grenada and Dominica; the quantity annually exported from both those cannot, I believe, be estimated on an average at more than four thousand bags of one hundred weight (112 lbs.) each, which may be worth, at London market, between ten and eleven thousand pounds sterling."

This extract as will be observed does not say anything about Trinidad because, as I have said, Trinidad was not at the time a British possession; but 
there is another book-" Joseph's History of Trinidad"-not so widely read as it ought to be by the people of Trinidad ; from which I will give some ex. tracts, I will not attempt to recommend as gospel truth all that he relates about its decline in former years in Trinidad ; some of it appears somewhat absurd but I find what appears most absurd is also referred to by Bryan Edwards. Joseph's account is as follows :-

" Abbé Raynal, who in his historical romance never fails to assign a cause for every event, says the failure of the cocoa tree in Trinidad was occasioned by the north winds. Tradition, however, assigns the remarkable drought of that year (1725) as the cause.

"In 1725, according to records and tradition, the whole of the cocoa crop failed, and the greater part of the cocoa trees died. The sudden blighting of cocoa trees has often occurred in these islands and has generally been attributed to the appearance of a comet." ..........

" It is remarkable that we frequently hear of the entire blight of whole plantations of cocoa trees during the 17th and the beginning of the 18th century, yet I believe these events have not been known to occur for the last hundred years ; certainly not since 1756, when the inhabitants of Trinidad recommenced the planting of cocoa on an extensive scale, no general decay of cocoa trees has occurred.".........

"A more probable explanation of the event was given to me by an old gentleman, who stated it to be the opinion of cocoa planters, in his youth, that the 
trees that so generally perished were a variety of the cocoa which gave excellent fruit, but which were far more tender than the other two varieties, forastero and creole cocoa, so generally planted in Trinidad since the year 1756 . I am not sufficiently acquainted with cocoa to judge on this subject : my informant has spent the whole of his life on cocoa estates."

"Whatever the cause of the decay of the cocoa plantations, the effects were ruinous to the colony. It was abandoned by the greater part of its inhabitants ; and there are many letters and other documents in existence which speak of the history of those who remained behind; they had to dispose of their few articles of plate and even of their negro slaves to supply themselves with such necessaries as they could not raise on their plantations."

Joseph goes on to describe other incidents in connection with cocoa cultivation, but I think I have quoted enough for the purpose of this article. There are, or were up to a few years ago, traces of many small plots in what had become high forest lands, showing that cocoa had been largely cultivated; in some of the more favoured spots in the central range of hills. I know of one man near Matura who discovered a plot of over twenty acres of good cocoa hidden in the high forest and quickly availed himself of that knowledge to purchase a hundred acres that would include this plot. The verge of the forest in which it was situated was near the road-such as it was in those days-and consequently he made a good bargain, I believe there were others also who profited in a similar way. 
After the incidents related by Joseph cocoa seems to have had a precarious existence ; many converted their plantations into the cultivation of the, then, more profitable sugar cane. I have it on good authority that the sugar plantation known as $E l$ Socorro at San Juan, was formerly a fine cocoa plantation, but was converted into sugar cane. As such it was in full swing at my advent and so remained down to 1890.

Notwithstanding the fact that cocoa was cultivated in Trinidad more than 200 years ago, I assert that the industry was in its infancy when I came to Trinidad. Montserrat had just started and I think the whole district did not produce more than 600 bags a year. When Mr. Cipriani was Mayor of Port-ofSpain he began planting cocoa in that ward in 1877. In order to induce the Government to extend the railway to Couva, he assured Mr. Des Voeux that by the time the railway would be complete to that district, say three years later, that Montserrat would be able to supply 6,000 bags. This would therefore be six years after the time I fix the estimate at 600 . The output of cocoa from the Ward Montserrat carried by rail last year (1910) was 25,000 bags. A similar statement can be made relative to Arima, Caura, Chaguanas, Couva, Blanchisseuse, Erin, Manzanilla, Mayaro, Moruga, Toco. I mention them by wards, but there are many other large districts which I have not enumerated.

I have been asked by a well known agriculturist to " boom up Caura ;" I am sorry I cannot exclusive- 
ly do so, but I can bear testimony to the fact that that district has gone ahead by leaps and bounds, or to use the words of the gentleman alluded to, "its progress has been phenomenal." I have used his expression and I hope he will be satisfied, I could use it with, to my mind, more appropriateness to Sangre Grande, Manzanilla, Siparia and Bande l'Est Road. I have a very vivid recollection of the difficulties met by cocoa pioneers in these districts.

I remember my first ride from Arima to Mayaro along the eastern main road, between Sangre Grande and Manzanilla, seeing the land on which the fine estates of Mr. Hernandez, Mrs. Murray and others are now situated. They were in the course of preparation for planting cocoa and it then struck me as a miserable prospect, so miserable indeed that I doubt if I would have taken any of them as a gift had they been offered to me. Look at them now ! Flourishing beyond conception, making their thousands of bags each year.

Let me give another example. I remember accompanying Mr. Alexander Riddell from San Fernando to the place on Bande l'Est Road where he contemplated making a cocoa plantation. I, in my ignorance, wondered at the folly, as I considered it, of the cute Scotchman, and wished that I was safe out of the dreary morass, for in those days it was nothing better. Look at it now, and the neighbouring plantations begun at the same time, and what do you see? Places to delight the eye of the visitor and gladden the heart of the owners! No longer a 
morass but well cultivated fields of flourishing cocoa, large and comfortable dwellings with all the necessary outbuildings for carrying on the cultivation and curing of what is appropriately called "the golden bean.*,

Some years after this I again accompanied Mr. Riddell to his estate, then beginning to bear. It was at the time of the August crop. He had a small picking, but no sun to cure it, so it naturally began to spoil. "I wish we had some weeks of sun," he said, "if not it will be a bad look out for the cocoa planters." "It's a good job Mr. White doesn't hear you," I smilingly retorted, " he wants rain for the young cane plants. You see your interests are beginning to conflict, you want sun-he wants rain," (Mr. White and Mr. Riddell represented the same interest in the sugar line). "Oh, but man," he said, "Mr. White wants sun up at Ortinola too." "Did you ever read Max O'Rell's Friend Macdonald ?" I asked. "There is a story there that will tell you how to get whatever sort of weather you want." " No man, I don't read such trash," was his reply. "How do you know it's trash if you didn't read it ?" "Why," he replied, " everything an Irishman writes must be trash." "But Max O'Rell is not Irish ; he is a Frenchman," I replied. " It's all the same," was the retort ; neither has got any understanding, they're both blather-skits." “ 'Don't be hasty until I tell you what Max O'Rell says about

* An estate planted even later than Mr. Riddell's was sold within the last three months for the substantial sum of $£ 23,000$. 
your countrymen in his book called 'Friend Macdonald,' " I said, and I told him the story about the Jew and the Aberdonians. He laughed until I thought he would fall off the mule he was riding. "Thon's na sae bad," he said. Riddell was an Aberdonian, and, good fellow that he was, (for he has crosse "burn") always enjoyed a joke against his countrymen. "Weel, what aboot the prayers; if it's good as that I'll tak back what I said aboot the French." I then related the story about the prayers by the Scotch minister for fine weather for the crops and a particular sort of weather to enable him to save his hay. I had just read "Friend Macdonald" and it was fresh in my memory. Here it is, as far as I can recollect it ; if not in the exact words it is a fair substance.

" The hay making season came round in a certain district in Scotland and it was arranged that the minister should pray for appropriate weather ; he accordingly prepared to do so, but in order to be sure of that which suited his own case best-for he also had hay to make while the sun shone-he knelt down in his bedroom window which overlooked the hay field. As he prayed a strong gust of wind came and scattered the hay right and left. The minister lifted up his eyes in horror and said : "Oh Lord, that's too bad ; I didna ask for a tearin, blusterin, roarin win, I asked for a soughing, soothing, dryin win to save the hay." Riddell, who was an elder in his " Kirk." was pleased at the joke. I believe he also, in due time, got the sort of weather that suited him. 
There are not many places in the colony where greater strides have been made and finer cocoa plantations been recently opened than along the Moruga Road and on to La Lune. In my early days travelling alone through this district was wearisome. It was a mass of forest, occupied by red monkeys, flocks of green parrots and, it was said by a planter well known for his veracity, by lions also-although I never saw or heard any yet he positively alleged it. He had been a sugar planter in another part of the colony and I suppose, like others, foreseeing sugar's downfall, changed to cocoa. He was, I think, the pioneer of cocoa planting in the Moruga district, or at least cocoa planting on a large scale.

Now the whole of that jungle, for miles each side of this road has been opened up, the roads over the steep hills diverted, the road made driveable even by the motor car-I recently travelled over it in one in 40 minutes, it formerly took not less than six hours-I wonder what has become of the roaring lions, the red howling monkeys and the screaming parrots, in those days if you did not know you would think that you were a good many miles from eivilization, whereas in reality you were quite close to it. Sometimes the crowing of a cock or the braying of a donkey reminded you that you were in the neighbourhood of civilization.

\section{Peasant Contractors.}

If we want a fair illustration of what the peasant contractors have done for the cocoa industry in Trinidad, and the almost insurmountable difficulties 
they had to deal with in transforming what looked like rugged inhospitable, barrenness into a " smiling prosperous garden," let me take you for a ride or drive over various parts of the colony where cocoa now flourishes. You will not only be delighted, but struck with wonder. But after all, we need not travel far. Let me take you to the top of the "Saddle Road." There let us pause and look round on the hills and vast amphitheatre spread out before you. The greater part of it once formed Moka sugar plantation, but like many others it is now transformed into what will in a short time be one of the most magnificent cocoa estates in the colony. When I carry my memory back, not so many years either, and remember that looking over the hills to the west and north it never entered my head that they would ever be anything more than what they then appeared to be, an almost impenetrable mass of "bush and brake" overshadowed by huge forest trees; what do we see now ? The forest trees are felled, the inhospitable "bush and brake" cut down and burnt, the mountain sides in the course of being prepared for, and planted in, suitable shade for the young cocoa, which in a few years will be in flourishing plantations-for I believe there is more than one owner to what we see spread out before us-showing what human energy can accomplish.

Trinidad owes to her peasant contractors a great deal more than she is prepared to admit.

It must not be thought that the few places selected to illustrate my assertion are the only places in 
the colony to which what I have described applies; there are many others to which it equally applies, ns for instance phenomenal Caura, Maracas, Toco and the whole of the north coast and other hilly districts, but I have specially chosen Moka as being the most accessible to visitors coming to the colony.

I have said elsewhere that I am unable to say much about Tobago ; I, of course, mean in comparison with Trinidad, because my visits to Tobago have only been casual whereas Trinidad has been my home. I have, however, frequently travelled over its roads and round its coast which contains some magnificent bays forming ideal spots for either a colonial residence or a site for health resorts. In my early days the roads were merely steep bridle tracks ; now many of them have been converted into good carriage roads.

It was formerly, like the Trinidad of Then, solely sugar producing and like the Trinidad of Now it has extensive cocoa, cotton and rubber cultivation and its improvement in cocoa cultivation alone is something wonderful. I hope that giving prominence to the names of some of the gentlemen concerned in developing Tobago will not be distasteful to them.

I select a few of the most prominent with whom I am casually acquainted as follows :-Mr. R. B. Archibald, Mr. H. R. Hamilton, Mr. Thornton, Mr. Robert Reid, Mr. Tucker, Messrs. Turpin, Mr. Orde, (Rubber Syndicate) Sir W. Ingram, Major Walker, Captain Short, and many others, all of whom by their 
energy and enterprise are tending to bring Tobago very much to the front.

For the information of residents outside the colony I will endeavour to give a description of Cocoa, Cacao, or Chocolate bean, as it is variously ealled; they must not confuse it with the cocoa-nut, which is very different, the latter being of the paln family.

The cocoa tree, both in size and shape, somewhat resembles a cherry tree. The flower is a saffron colour, extremely beautiful and delicate, and the pods, which in a green state are like a cucumber, grow from all parts of the body and large branches ; you will see them growing down to the very roots. As they ripen they change their colour and turn to a fine bluish red, almost purple, with picked coloured veins. This is the common sort ; but there is a larger species which produce pods of a delicate lemon colour. Each pod may contain from twenty to thirty nuts or kernels, not unlike almonds which are again enclosed in a white pulpy substance, soft and sweet, and immediately enveloped in a parchment shell. I will not attempt to describe either the cultivation or curing, except to say that a tree when planted does not become full bearing much before five years and often longer. The curing process takes from ten to fourteen days, according to the amount of sunshine available. Chocolate as a beverage is much esteemed by West Indians in general and is fast becoming popular all over the world in this respect, and as chocolate creams, the very children 
know it. Who has not heard of and indulged in Cadbury's, Epps' and Fry's cocoa and chocolate, all of whom are large buyers of Trinidad cocoa and one at least, Messrs. Cadbury, has large interests in Trinidad (see page 9 ).

Bryan Edwards states that a Colonel James, the first white man born in Jamaica after the conquest of that island by the English, lived to the great age of one hundred and four years, and for the last thirty years of his life used scarcely any other food than chocolate.

Cocoa has, like other industries, its bad and good years, and the present year (1912) has not been by any means a good one. Bryan Edwards says " it shrinks from the first appearance of drought ; and again, " the appearance of a comet was always considered fatal to cocoa plantations," and Abbé Raynal makes a similar statement. Don't accuse me of being superstitious ; I merely relate facts, and coincidences are undoubtedly strange things. Whatever doubt there may be as to the effect of the comet in May 1910 on our crop, there cannot be the slightest doubt of the effects of the drought of 1911-12 which has been the most unprecedented since 1869 . 1912 has been held by many people to have been much more severe than even that year.

There are a few estates whose managers I not only personally know but have also been their guest for longer or shorter periods, and I personally know that they have suffered during the crop season of 1911-12 to an unprecedented extent from the drought 
during that period. One large estate which in 1910 made 2,100 bags, will not this year make more than 600 if even so many. Hundreds of trees have completely died out and are now only fit to be cut down and used as firewood.

I hope, however, that this will not dishearten people, for, after all one exceptionally dry season in 43 years cannot be regarded as disastrous to a cultivation which has outlived hundreds of years. With a reasonable amount of moisture, there are still bright days in store for cocoa cultivation which I am sure will justify me in saying that nothing in this colony has progressed and, I hope, will continue to progress, with cocoa, making a great contrast with the Trinidad of Then and the Trinidad of Now.

A few words more and I conclude this chapter on Cocoa. Compare the export of Trinidad cocoa in 1876 , two years after my arrival, with that of the present time. In 1876 it was only 47,885 bags ; in 1910 it reached the enormous output of 280,862 bags and in 1911, notwithstanding that it was a bad year it has reached 289,000 bags. This calculation has been made on bags weighing $200 \mathrm{lbs}$. each. We can therefore, in this item alone, see the tremendous strides which Trinidad has made in its progress and prosperity, as compared with Then. 


\section{CHAPTER XXI.}

\section{CARNIVAT.}

FAmiliarly kNOWN as "Masquerade."

Were it not that I am limited by my contract for the printing of this book to a certain number of pages and that they are fast drawing to a close I would writè at least three chapters on the festival known in Trinidad by the name of "Carnival " or "Masquerade." Carnival, to give it its proper meaning, would indicate a religious festival but, to give it its literal meaning here, means a time of debauchery and lewd revel, the real characteristics of which few people in Trinidad know better than I do. How long, those who are supposed to be a christian people, will put up with its open, and, what is much worse, its hidden obsecnities, is a matter for this people to decide ; theirs is the duty and theirs is the power. I am glad to see that a member of the Legislative Council intends to call attention to it ; I hope he will do so in no half-hearted way and that he will be supported by the voice of all the clergy in the community irrespective of their denomination.

The history of the Carnival in Trinidad is somewhat obscure, but that it was in existence at the time Trinidad became a British colony is, I think, pretty 
certain for soon after that date I find a notice by the then Inspector of Police which reads as follows :-

NOTICE.

“The Public are hereby informed, that

\section{MASKS}

are strictly prohibited in the streets, until the 18th of February next.

Any person being found Masked in the streets will be immediately arrested and dealt with according to Law.

\section{JAMES MEANY,}

Chief of Police.

From the time of my arrival in Trinidad I endeavoured to ascertain its origin and although I consulted well informed people I was unable to do so. I was told, "Oh, it is an old religious festival." One thing must however, be apparent to all beholders, that whatever it may have been in the old days there is not now the slightest form of a religious ceremony connected with it ; the very contrary is the case.

It is, however of the old-now defunct-Cannes Brulée that this chapter will treat, including some of the circumstances connected with its suppression and with which I had not a little to do, which at the time created such an amount of bad blood and undeserved hostile comment.

The meaning of Cannes Brulée is Cane Rat, and it is therefore difficult to understand its connection with the senseless and highly dangerous saturnalia 
which its carrying out caused. There must be something in human nature, no matter from what race it springs, which delights in returning to its uncivilized state, for one thing is certain to all beholders that there is a relic of barbarism, in this carnival.

The following is the account of the origin of the Cannes Brulée, given before Sir H. C. Hamilton when he came here to enquire into the disturbance arising out of the suppression of this saturnalia in 1881. I quote from his report :-

"In the days of slavery whenever fires broke out upon an estate, the slaves on the surrounding properties were immediately mustered and marched to the spot; horns were blown to collect them to their work. After emancipation, the freed slaves began to represent these scenes as a kind of commemoration of the change of their condition and the procession of the "Cannes Brulée (burning the cane rat) used to take place on the night of the 1st of August......" After a time the day was changed from the 1st August (and the informant might have added 'The Carter's Races' instituted in its place) and for many years past the Carnival days have been inaugurated by the "Cannes Brulée.',

Mr. Osborn Inniss, an old inhabitant of high standing, gives a totally different origin to it, he says :-

No one at the time seemed to know whence the custom came and what it signified, but I have since (meaning since the holding of the commission) had reason to believe that it must have been at first 
intencied to represent the crowd of men, with torches and staves, sent by the Chief priests to arrest Our Saviour in the Garden of Gethsemane."

I (the writer) do not agree with either version, both are far-fetched and mere guess work. The following was the real reason for this procession. Carnival was originally held on three days, instead of as at present two, viz : Sunday, Monday and Tuesday.

The religious susceptibility of the better class of people were aroused and they protested against the sacredness of the Sunday being disturbed by this saturnalia. Consequently Sunday was prohibited from being one of the days on which the Carnival could be held-if the legislature did what was done in later years, name the hour at which it was to begin it would have been a wise measure, but they did not and as Sunday was considered as ending at 12 o'clock midnight, it opened the door for the re-introduction of the old torchlight procession formerly held in celebration of the abolition of slavery. This certainly was a short-sighted policy and was the means of introducing the more objectionable features, that could not have taken place in the light of day.

Anyway, Cannes Brulée had been established on an illegal basis and no matter how long a weak executive had winked at it its days were numbered, but not without a struggle. Captain Baker was appointed head of the Trinidad Police Force, and taking a little time to look about him he soon saw the objectionable part and the danger to the town the Cannes Brulée procession played in the festival 
known as "The Carnival," and determined to begin by suppressing this part of it. He was advised that it was a violation of Section 63 of Ordinance 6 of 1868.

In 1880 he took the first step to suppress it. This step met with universal praise from the press ; but, for reasons which it is better not to divulge, in 1881 the viler passions of the lower class having in the interval been aroused against him, his efforts in the same direction met with organised opposition and subsequent abuse from those who previously praised him.

Year by year just before the Carnival-particularly the Carnival of 1881-broken stones were spread out on what were, and I believe still are, called "the French Streets," that is, all the streets lying east of Henry Street. The police of those days were wicked enough to say this was done for the purpose of affording the various bands who made these streets their " happy hunting ground" ready material for assaulting them when they, as a Borough Councillor put it to an over credulous governor the day after the "Cannes Brulee" riot "brutally interfered with the people's innocent amusements." Such incidents in the history of Trinidad have happily passed away-never to occur again. The influential and educated people who were at the back of the ignorant demagogues who were responsible for it, have also passed away-let us be charitable and hope to a better place. 



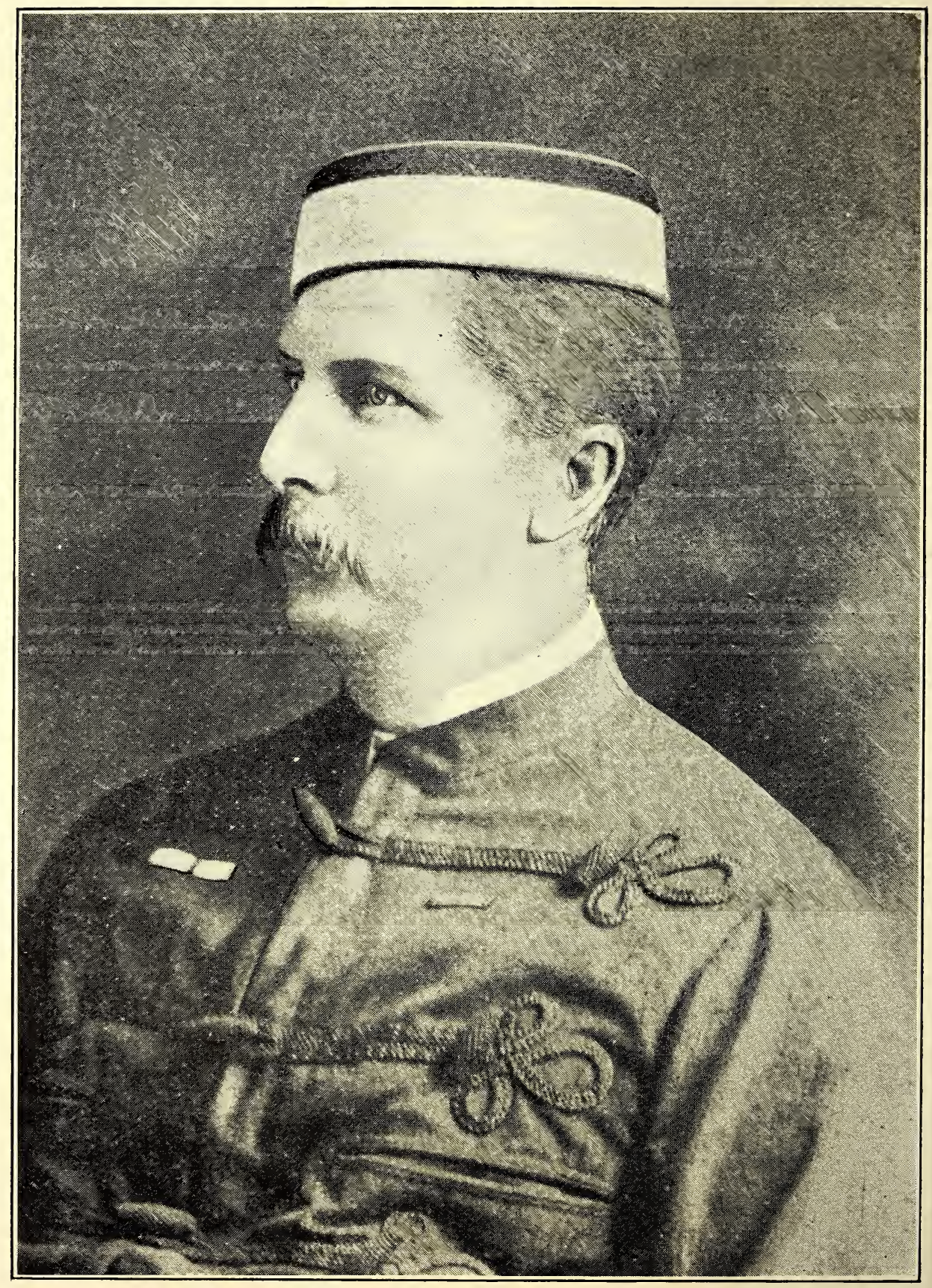

" BRAVE BAKER, OF THE BOBBIES." 
I may be here permitted to give at full length a parody written at the time of this émeute, and published in the Trinidad Chronicle. It gives an amusing, but at the same time truthful, description of what occurred :-

\section{A I.AY OF CANBOULAY. *}

Brave Baker of the "bobbies",

By the " tarnal gods" he swore

That the people of old Port-of-Spain

Should masquerade no more.

By the " tarnal gods" he swore it

Then thought of Canboulay;

And bade his trusty followers

Be ready, " come what may."

East and west and north and south

His messengers ride fast

To summon all the " bobbies" forth

At the sound of trumpet blast.

Shame on the false policeman

Who lingers at the call,

Since their brave leader thus hath sworn

To make the flambeaux fall.

Forth from the hills of Belmont

Where scowls the far-famed hold

Of ancient masqueraders

And band of rioters bold,

Where sweet Dry River wanders

Through slums and dunes of sand

Came forth the dusky warriors-

An armed and noisy band.

Then from the Barracks' tower

Could the " wary bobbies", spy

The lines of flaming flambeaux

Red in the midnight sky.

Just then a scout came flying,

All wild with haste and fear

"To arms! to arms!" said Baker

By the "tarnal gods" they're here."

* This was the popular name given to the "Cannes Brulée." 
Then forth went all the "bobbies,"

And forth went Baker too,

And when they got to where 'twas hot

At once their staves they drew.

" Down with the torches!", Baker cried,

"6 With all the speed ye may,

I with two more to help me

Will hold the foe in play.',

Then out spoke "6 dapper Owen ; "

From San Fernando he :

" Lo, I will stand at thy right hand

And fight the foe with thee."

And out spake big Concannon-

Of Hibernian blood was he-

"I will abide on $t$ 'other side

Shure it's nothing but a spree."

Ho! flambeaux flash the war-note, Ho! " bobbies", clear the way!

The leaders ride in all their pride

Along the streets to-day.

To-night the lamps and windows

Will suffer in the fall

From top to bottom of each street

And e'en from wall to wall.

Then down at once the flambeaux went,

And staves and sticks they drew,

And in and out and all about

The stones and bottles flew,

Hotter and hotter the battle raged

Till near the break of day;

Full many a head and many a lamp

Were cracked in the affray.

From night till morn the battle raged,

The streets with blood were red

From many a cut and many a wound

And many a broken head.

The " bobbies" were victorious

And back to barracks went;

The furious crowd, all up and down,

Cried, " to-morrow night we'll burn the town

Our anger's not yet spent.", 
There be several chosen Councillors-

The wisest in the land,

Who just now by the Governor

Do morn and evening stand.

And with one voice these Councillors

Have their glad counsel shown-

"Go forth! go forth ! Sir Governor!

Go forth and save the town.',

Then forth went the gallant Governor

To the stately market-place;

Went to harangue the riotous bands

And meet them face to face.

And fearless out he boldly spoke,

'Mid cheers and shouts so gay;

"I've come to have a little talk

With you, my friends, to-day",

" I'm not afraid to trust myself

Amongst you in your fun ;

The police were wrong, the thing's a hoax

And all's been overdone.

The "bobbies", all shall go away,

The soldiers leave the town,

And you may do just as you please

If you don't burn it down.',

And now with yells the mob is gone,

The Governor homeward bent,

The police shut up-the soldiers gone-

The town to maskers lent.

And thus my lay comes to a close,

We've all of us been sold!

'Tis past-perchance in future time

Some other bard will sing the rhyme,

Of the brave days of old.

\section{MACAULAY REDIVIVUS.}

It may be thought or asserted that the Governor's words :

"I've come to have a little taik

With yoa my frianls to-7ag." 
etc., etc. are an exaggeration ; let me give his exact words and then judge ; they were as follows :-

' My friends, I am come down this afternoon to have a little talk with you. I wish to tell you that it is entirely a misconception on your part to think there is any desire to stop your amusement..... I I had no idea what your masquerade was like. If I had known you should have no cause for dissatisfaction ; there has been entirely a misconception on all sides, for the only reason for interference was the fear of fire. I thought the carrying of torches at this time of the night might be attended with danger and $I$ was anxious to guard against it....... You can enjoy yourselves for these two days and I will take care that the police do no interfere with you. I will give the town to you for your masquerade if you promise not to make any disturbance or break the law. I will give orders that the police shall not molest or interfere with you. If you keep within the law there shall be no interference with your masquerade."

It will be seen that these lines set forth in a fairly accurate way what took place on the night of the "Cannes Brulée" riot and the following day. Two of the Councillors alluded to-there were otherswere Borough Councillors backed up by two prominent, and with the lower class influential, citizens ; one a general contractor and the other a man holding a very mionr government appointment. The governor did go to the market place, and spoke to the mob, ordered the police and soldiers to their respec- 
tive barracks where they remained during Monday night and the whole of Tuesday till Ash Wednesday morning. The minor government official headed a mob on Tuesday to the space of grass between the Court House and Police Barracks and there burnt Captain Baker in effigy, a foolish thing, which, like the curse in the Jackdaw of Rheims, did not make Baker " a penny the worse."

There was another important event which the public never knew and it was well they did not. The whole of the Police Force at Port-of-Spain, except the officers and a few of the higher non-commissioned officers, laid down their truncheons, took off their uniforms, folded them nicely, laid them on their cots, wrote and signed a paper tendering their resignation, marched downstairs in a body to the Police barrackyard, handed in their resignation to the SergeantMajor and boldly declared that they would not serve under such a governor. It took a very considerable amount of persuasion and reasoning from an influential, high-classed non-commissioned officer to induce them to withdraw this resignation and put on their uniforms ; eventually this was done and done quietly. It had, of course, to be reported to the Governor who became frightened when informed of it. He wanted to come to the barracks to address the men, but was advised to let well enough alone, and he wisely took the advice.

Imagine what would have been the result if this strike-mutiny-call it what you will-had become known to the mob while they were careering through 
the town, with liberty to do "just as you plerse." What would Messrs. A, B, C, and D, who advised the Governor, have been able to do with these innocent people and their "fun" or, as they put it, " innocent amusements"?

I am to this day a living witness that it would have been impossible for any body of men to behave better or act more bravely than did the police of all ranks on that night. Eighty men, (only four of them mounted) armed with truncheons, cowed and overcame an infuriated mob numbering thousands. From the time I first knew this force I had confidence in it, and from that night to the day of my severance from it, that confidence in its integrity and bravery never changed. The strike was not on their own account, but, as they forcibly put it, " to express their indignation at the way their several leaders of the night before had been treated by a-_-governor.

Do demagogues and those who, for some mistaken purposes, urge the people on to the performance of some foolish act ever pause to think of the frightful risk they run, and the jeopardy in which they place innocent citizens when they harangue an irresponsible mob, with hints to oppose lawfully constituted authority ? Or when their efforts have been even partially successful, do they realise the injury they did to, and the stigma they have placed upon, their country ? It is easy to inflame the passions of an excitable people, but it is difficult to control or subdue them when they turn them into a riotous mob. 
After the "Cannes Brulée" émeute, referred to Mr. afterwards (Sir Robert) Hamilton, Mr. Gladstone's Private Secretary, afterwards Governor of one of the Australian colonies, was sent from England to enquire into it. On his recommendation a stringent ordinance, "The Peace Preservation Ordinance " 11 of 1883 amended by 2 of 1884 unfortunately instead of being kept separate has been embodied in No. 5 of Revised Laws-was passed which gave the police great powers over the riotous bands of the colony. I have used the word " unfortunately" because I am satisfied that since it has been embodied in No. 5 it has not been properly understood by the police ; if it had been kept separate its purport would have been understood and enforced, as it was intended to be, it would by this time have rendered this indecent Carnival a thing of the past.

I will, however, quote one important paragraph from Mr. Hamilton's report, it is as follows :-

"As regards the police, I think it is absolutely necessary in the maintenance of law and order, that they should be fully supported in the execution of their duties. Unless this is done a much larger force will be necessary, and peace and order will not be so well maintained. What gives a policeman power in a mob is the feeling on his part that he represents authority, and will be supported by the ruling powers. Deprive him of this he only becomes himself a unit in the mob, with no more power to preserve order than is derived from his own personal strength and courage." Pregnant and powerful words these, 
worthy of being remembered for all time. How did the governor like them ?

And now in conclusion, a few words more by one of the 80 men now remaining who successfully withstood that desperate onslaught of that desperate mob and conquered ; that night,- -as I have said-assured me that the Trinidad police could be trusted to do their share, and I am glad to say I never had any reason to think otherwise; I am satisfied, that should such an event unfortunately occur again that they will be found equally reliable.

In the days alluded to there was more rowdyism but I think, on the whole, less indecency than at present during Carnival, or at least less open indecency. People call this orgy, for it is nothing less, a harmless amusement, but where the amusement comes in I have never been able to see. I know it has brought degradation and shame on many a hitherto innocent girl. Has not the time come for the better class of citizens, by advice and precept, to get rid of this pest? It could, in my opinion, be easily done. I daresay a set of demagogues and those financially interested would oppose it; but surely a people who have been able to pull Trinidad out of the mire in other matters ought to be able to do this. I am, however, satisfied from my long experience that Trinidad will in time see the Carnival abolished. I hope in expressing this assurance that "there is a note of prophecy for the future which is full of encouragement and good omen." 


\section{CHAPTER XXII.}

THE CUSTOMS AND POST OFFICE.

There are no departments in the colony which have improved so much within my time as the two named above. Let me begin with

\section{The Customs.}

It is difficult to describe the state in which the Customs-one of the most important institutions in the colony-was in my early days, and I think I had better not attempt to lay bare all its shortcomings, because I certainly could not successfully do so without sitrring up a lot of mud; all that I will therefore say is that the building then set apart was a nest of filth, disorder, irregularity and fraud. The frauds first discovered were within the department itself and were committed in a department, which, if not honestly conducted, lends itself to so much frauds. I am not sure that I know what led to the discovery of these frauds; but to them I owe a good deal of my after insight into the devious ways by which frauds could be so easily committed in a department not then too well looked after. To it I also owe a good deal of what afterwards proved of such help to me in my career in the Police Force, for through them I was brought into contact with an able and also a fair conscientious prosecutor ; I allude to the late Mr. L. D. O'Connor, at that time Crown Solicitor, 
whose straightforward methods formed the groundwork on which I was in after years able to build the system by which I successfully prosecuted many important cases entrusted to me.

The frauds on the Customs were then committed through the loose way in which drawbacks were allowed. To the ordinary mind of those who are not acquainted with the meaning of "drawback" as applicable to Customs duties, I will endeavour to explain it.

A—, a merchant, imports dutiable goods the greater part of which he intends for export. $\mathrm{He}$ is allowed to keep them in bond till he is able to dispose of them to customers in the neighbouring republic of Venezuela or one of the neighbouring colonies. When taking them out of bond he pays warehouse rent, makes a declaration that they are for export and enters into a bond for the due fulfilment of his declaration. If he has not sufficienc goods in bond, of the required sort, he is allowed to make them up by shipping others on which he has paid duty, making a similar declaration and entering into a similar bond ; he then gets a drawback, that is, a refund on the duty already paid by him.

The goods are then taken to the sloop or other vessel in which they are intended to be shipped, but the sloop does not go to either place but simply goes into a quiet bay in the colony, unships them and delivers them to an obliging shopkeeper at a much cheaper rate than he would have received them if the duty had been paid. 
A - may or may not be a party to the fraud but in either case the Customs is defrauded. In the case to which I am alluding they did not even take the trouble to do this ; an obliging landing waiter simply certified that the goods were shipped, when in reality they were sent to their real destination under the eyes of the officials in Port-of-Spain.

Any way, these frauds were one day brought to light and I will simply relate of one group, I think there were five in all implicated, two landing waiters and three merchants. I must here relate an incident relative to this case which nearly wrecked the whole set of cases.

I need not enter into all the details, suffice it to say that several arrests were made and the offenders charged with their several offences. One merchant who was only the cat's paw of the others having been arrested retained Mr. George L. Garcia, an able barrister, afterwards Attorney-General, to defend him ; he seeing that his client was the tool of others advised him to become a witness for the Crown. He was arrested on a Saturday afternoon and bailed to appear on the Monday. Mr. Garcia having heard his statement went direct to the Crown Solicitor and made the proposal for his client to be accepted as "Queen's evidence." Mr. O'Connor would not consent to this without consulting the Attorney-General, and to him they repaired. They arranged for a consultation to take place on the following morning, I being present. Mr. Garcia made his proposal which the Attorney-General promptly de- 
clined. I was somewhat astonished and whispered to Mr. O'Connor " ask the Attorney-General to permit me to speak to him in private" thereupon the Attorney-General asked Mr. Garcia to remove for a moment, which he did, and I immediately said to them, "I think you ought to accept Mr. Garcia's offer, in my opinion you have no case against B-_" "What do you mean, do you not think these documents sufficient evidence ? "Yes," I replied, " if you can prove them to be his handwriting." " But they are," he said. " They are not," I replied, " the man can't write, these documents were not signed by him, therefore on that part of the case which is the only evidence you have against him you must fail." " How do you know that he can't write asked the Attorney-Gen:ral ?" "Wait for a moment and I will show you," I replied, and went to my office and procured the bail bond which the accused had signed on the previous day. It was signed with a mark as follows :

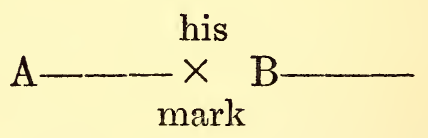

This settled the case and B-was accepted as a witness for the Crown. Mr. Garcia did not understand it and on various occasions tried to get out of me what I had said or done to convince the Attorney-General. I invariably replied "After the case against the other men is tried by a jury I will tell you," and when it was tried and the other men convicted-mainly on B-'s evidence-I told him. 
The look of disgust on his face was worth witnessing and in words more forcible than polite he exclaimed "what a b-ass I was not to have noticed that; why I would have been retained by the whole batch and if I had seen what you observed ; I would have got them all off." "You would have had a good chance," I said, " but then you didn't observe and that made all the difference."

After this case a sharper look out was kept and many other cases of frauds, or attempts were discovered and a better check was put on them; but I am afraid they were not altogether stopped ; it is not always an easy matter to stop abuses of any sortexcept by slow degrees-when they have once obtained a footing, you don't know who is in the swim and must therefore patiently abide the issue.

After these frauds and other irregularities were discovered Mr. Robinson from the Imperial Customs was sent here, and on his recommendation a new and more up-to-date Custom House was started. Mr. John Fanning, well known to the mercantile community for his strict, and, as was thought by some, over strict measures, was sent to reform the customs and that he did so with firmness is a matter of history. He, also, had tons of mud thrown over him, and if he had been a weak man-which he wasn'this life would not have been a happy one; he was an able man, and after a time the general community began to recognise it. $\mathrm{He}$ was in course of time, succeeded by another clever and capable man in Mr. R. H. McCarthy, who also had to run 
the gauntlet of abuse and misrepresentation of a host of traducers ; but he also, before he left Trinidad introduced many stable reforms. The work begun by these two able men has been also ably carried out by Mr. Walcott the present head of this important department.

The present Customs buildings were commenced in 1880 and since then have been three times enlarged. The Customs duties which in 1875 amounted to $£ 117,281$ have in 1911 reached the respectable figure of $£ 405,710$. I could say a good deal more on this subject but let what I have said suffice, little as it is it will illustrate the great difference between the Trinidad of Then and the Trinidad of Now.

I now come to deal with

\section{The Post OfFice.}

This Public institution had to be pulled out of the mire into which it had been allowed to sink before its reformation began which placed it on its present high pinnacle under the able hands of Mr. J. A. Bulmer, I. S. O., whom I am happy to be able to count as one of my most intimate friends. He, like myself, had to struggle against adverse criticism and he like myself, overcame it; not perhaps, without being the object of a little mud-throwing, for which I am sorry to say Trinidad was at one time notorious. If ever a country believed.in the old trite saying " throw plenty of mud some of it is sure to stick" it was this colony ; and the mud-throwers in Trinidad in by-gone days did not 
hesitate to throw plenty of it even to the danger of besmirching themselves. Have they passed away? I hope so. (?)

Some time back I wrote a sketch in The Mirror in which I described the state of the Post Office as being more of a co-operative store than a Post Office, that the Post Office was to all intents and purposes subordinate to the co-operative store, then carried on in it. That statement was perfectly true but there I leave it ; things are, and, for a long time, have been changed for the better; still it is strange that what I sarcastically spoke of as having taken place Then is the absolutely accepted fact Now, but not conducted under the aegis of a cooperative store but under the aegis of the General Post Office. You can order your pound of butter or your pound of bacon, or your yard of cloth, suit of clothes, or pair of gloves, and they are as regularly and as safely delivered as they would be over any commercial counter in the country, the difference being-and it is a wholesome one-(C. O.D.) which being interpreted means " Cash on Delivery," which heads of families would like to see universally adopted.

Let me now essay the task of trying, in an imperfect way, to describe the wonderful improvements and strides made to bring this institution up to its present state of efficiency.

At length it was recognised that the Post Office was in need of a thorough reform and it became necessary to get an experienced official from the 
Imperial Post Office. Such a man was found in Mr. Bulmer, a gentleman of varied experience, who had been selected by the Imperial Government to establish a proper postal system in Cyprus, after that island had been administered by England under the Treaty of Berlin. Mr. Bulmer having completed his work in Cyprus was sent to Trinidad to reform and improve the Post Office here-and it wanted both. He soon began to establish a proper system all over the country, but want of sufficient funds crippled him for many years. He, however, persevered until by slow, but sure, degrees he laid the foundation for the splendid system that now obtains. Small rural offices were established in every accessible part of the colony, and indeed in many places that were then almost inaccessible. A larger building was purchased for Port-of-Spain and when altered the Post Office was transferred to it. A new office was built in San Fernando and in course of time improved offices were established in La Brea, Cedros, Couva and Chaguanas. Soon after Mr. Bulmer retired the present Postmaster-General succeeded in getting the present upto-date offices in Princestown and Sangre Grande.

As circumstances permitted the control of the rural post offices were taken from the police. I believe Matura is the only one now remaining. A good class of sub-postmasters and mistresses-many much under paid for such a responsible position-was appointed; letter carriers were allocated to rural districts and letters were delivered at nearly all over the country as well as in the more favoured towns. Post 
Office Orders and Parcels Post followed in rapid succession and many other up-to-date facilities were introduced by Mr. Bulmer, who tried for others, such as the introduction of the Island and British Postal Orders, the Cash-on-delivery System for parcels from the United Kingdom, the payment of customs duty and other charges on parcels from the United Kingdom, which enables the sender to forward a present to the addressee entirely free of all charges. But in this he was unsuccessful. Since then these and other conveniences have been obtained, amongst them reply coupons which can be exchanged for stamps to the value of 25 centimes ( $21 / 2 \mathrm{~d}$.) each, in any country participating in this arrangement. For the information of those who may not understand this, I give an explanation of the benefit to be derived from it. Supposing you write to some person in France or Germany for some information which you can scarcely expect them to go to the expense of a 25 centimes stamp to send to you, you get a coupon and forward it which they can exchange for the necessary stamps. Then we have the advice payment of money orders on Europe or India ; the extension of all money orders to $£ 40$ instead of $£ 10$ as was formerly the case ; the reduction of the rates of postage and the increase of the weight of letters ; the parcel post with Canada and the introduction of a direct money-order system with Colon, which is of great benefit to the people of this colony who have relatives there.

This long list of additions since Mr. Bulmer's retirement has been introduced by the present Post- 
master-General, who ably strove for and obtained them until at the present time no postal system in the West Indies can equal it.

There is no part in Trinidad, no matter how remote, that has not been reached by regular postal communication, in most places by establishing a Post Office, and where this is not at present possible by rural letter carriers, who distribute and collect letters as they pass along.

I remember many parts of the colony where there was only a fortnightly service, and it was considered a great stride when that was improved to once, then twice, then three times each week-every Monday, Wednesday and Friday from Port-of-Spain, with Tuesdays and Saturdays for the return journeys. There are a few places still out of the line, but what I have shown is, to me who remember the old state of affairs and the difficulties which had to be surmounted, proof of a great stride in the march of progress.

The Post Office must appear expensive when we take into account (that which many people are not aware of) the subsidy paid to the West India and Panama Telegraph Company by Trinidad (I do not know the exact amount) as well as the whole payment made for the coastal service viz : $£ 7,250$, and $£ 18,000$ paid as a subsidy to the Royal Mail Company is all charged to the Post Office. Is it any wonder that our Postmaster-General has often to refuse-for want of funds-to give to a deserving rural district a postal serivce of the simplest kind ? 
We may be able to understand why the subsidy of $£ 18,000$ lately granted to the Royal Mail for making Trinidad headquarters should be charged to the Post Office ; but it is not so easy to understand the subsidy to the West India and Panama Telegraph Co. and the subsidy of $£ 7,250$ for the coastal service, which is of little use to the Post Office, except as regards Tobago, should be also charged to it.

At the time when Mr. Bulmer took over the management of the Post Office, there was a great deal of petty pilfering by abstracting money enclosed in letters to friends and particularly to neighbouring colonies, and particularly again to those sent to Nevis. This caused a good deal of worry on account of the difficulty of locating the exact place where the peculation took place. Mr. Bulmer was of opinion that it was done on the Solent, one of the intercolonial boats, tor, strange to say, it was generally the mails sent by that boat which suffered most. The task of finding out the culprit was deputed to me, and from such information as I could collect I was of opinion that Nevis was the place to look for the thief. I accordingly went there, but, strange to say, nothing went wrong that trip. I was known to some of the officers of the Solent and as it was the Solent which went to the Northern Islands on that voyage it was still unsatisfactory. However, notwithstanding this, I suspected a boy employed by the Postmaster at Nevis as a servant as being the culprit, but still Bulmer stuck to his suspicion of the Solent. I went again and took with me a little cockney sailor named 
Livingbird, who had been on the Pandora when she was wrecked in the second Bocas. We had selected a few of her sailors for service in the Police Force, and Livingbird was attached to the detective department where he proved himself to be intelligent and useful. Being an old sailor he was able to mix freely with the sailors of the Solent, which when we got to Barbados went on to Demerara. While on inis way to Barbados, which in those days took three nights and two days, he satisfied himself that the sailors had no opportunity of tampering with the mails ; so when we got to Barbados I continued on to St. Kitts and then passed over to Nevis.

A rumour of this state of things had reached the neighbouring colonies and numerous were the complaints received from them of money having been abstracted from letters. On the last occasion when on my way to Nevis I called on Mr. Trimmingham, the Postmaster-General of Barbados to talk over matters with him, as frequent complaints were also made by his department. While in his office one of his clerks brought in a slip on which a complaint was made about a letter containing $\$ 10$ being missing, the person who was to receive the money having been notified by another letter that it was sent. "Where were these letters posted," I asked. "At Arouca" was the reply. Now I happened to know the postmaster at Arouca to be not only a careful but also an honest man, and I told Mr. Trimmingham so. "Well, there is the fact " he said, " you can't get over that." " No," I replied, " if it is a fact, but as I am here 
let me have a look for myself.'" He consented and I went along with him into the sorting department and began to search; there I found the missing letter carefully hidden away. There were, so far as I know, no more complaints from Barbados.

But let me resume about my journey to Nevis. I had, of course, told Livingbird about the postmaster's boy in Nevis. On landing he attached himself to him and was not long in getting at the bottom of the mystery. He had a list of the people from Nevis residing in Trinidad-especially in the country districts-who were in the habit of sending money to their relatives in Nevis and he was able by the feel of the letter and the post marks on the envelope to fairly guess when money was enclosed and then he appropriated the letters. The boy was arrested, and on boing placed before the magistrate of Nevis he confessed the whole matter and how he used to work. Addressing the magistrate he said : "He call himself Livingbird, sir ! but he no living bird; he a jumby bird.'"

The introduction of Post Office and postal orders between this and other colonies put a stop to this system of stealing from letters, as it did also in this colony, where the offence was at the time pretty frequent. Notwithstanding all the ups and downs of the Post Office I am glad to be able to assert that there is no institution in the colony that has made more rapid strides than the postal system inaugurated by Mr. Bulmer and so ably continued by his successor. Since the early days of the Post Office co-operative store 
down to the present there is no department in the colony with which I have been more intimately acquainted than the Post Office, as Mr. Bulmer frequently asked for and got my assistance in selecting the most convenient sites for placing local offices. In this way I gained a good deal of knowledge. I am therefore able to speak with authority.

The Post Office in a small place, such as Trinidad is, can never be such a money-making concern so as to be a source of revenue to the colony ; the expenditure must always be above the receipts, but as time advances the service may be improved at the same cost ; as, for instance, when the railway is extended the carriage of the mails to many places will be more expeditious and less costly.

That occasional abuse will be levelled at it by discontented grumblers is only to be expected, because that is a chronic complaint relative to everything governmental, and the Post Office cannot expect to be the exception. So long as the Postmaster-General or any other head of a department keeps pace with the times, people must learn to be satisfied. And I who know it assert that Trinidad is keeping abreast of the times in a very marked degree and that is all that can be expected. As I have shown, the Post Office of Now forms a great contrast with the Post Office of Then and I am sure that as time moves on it will con. tinue to do so. 


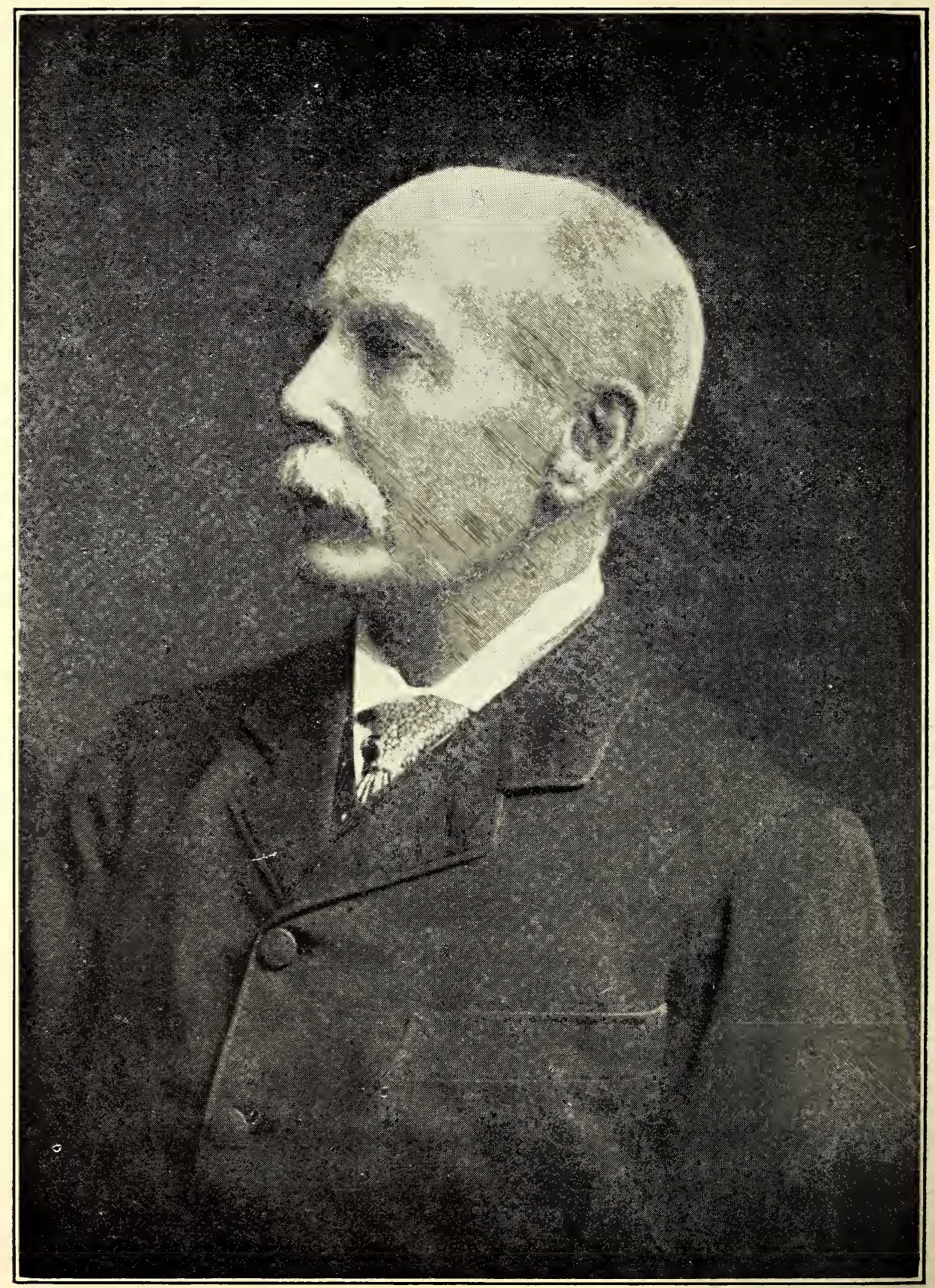

THE AUTHOR-“NOW." 


\section{ENVOI.}

The last chapter on general subjects being finished it behoves me to say a few words before closing the book and to apologise for its many defects. Having carefully read over what I have written, I have come to the conclusion that some of the chapters or sketches are much longer than they ought to have been, thereby shutting out more interesting matter which it was my intention to have included but which I have been reluctantly compelled to omit. Prolixity is, I believe, the fault of all beginners and I am afraid I have grievously erred in this direction.

In the introductory chapter I gave a list of the books I had consulted and taken copious extracts from. By an unpardonable oversight, which I can only account for in one way, I omitted to include Sir Louis de Verteuil's able work on Trinidad of which Canon Kingsley wrote, "It is one of the most complete monographs of a colony which I have yet seen." I was always under the impression that this valuable work was written in French. Why, I know not, except that I confused it with Mr. Borde's " History of Trinidad" which was written in French. I am glad however, to be able before concluding, in a small degree to remedy it ; accident helped what I had for so many years missed and has thus enabled me to quote 
two passages, one of which ought to have been included in the chapter on the Inhabitants, a quotation which would so aptly have coincided with the one I quoted from Trollope (see page 154), it is this :-

"The fate of the white and the black man is intimately connected, and in these islands, where slavery no more exists, they must rise or fall together. Highly mistaken are those who think that the emancipated Africans are able to carve out their onward destinies by their own unaided efforts and that the presence of the white man on the same spot with them is an obstacle to their advancement."

I am glad to be able to quote such a sound passage from the pen of so able a man as Sir Louis de Verteuil, a brilliant and versatile son of the soil, descended from one of its oldest families and one whose opinion must carry great weight with his countrymen. The other passage I have quoted in the dedication.

In writing this book I have tried to map out a course somewhat different from other writers, and my endeavour has been to avoid raising contentious points which time alone can remedy. It is probable, that notwithstanding this, some portion of it will be found unacceptable to all, but if so that cannot be helped. I have endeavoured to portray things and events as they appeared to me, and whenever I came across anything in other books which coincided with my own ideas I have not hesitated to use it.

I have said that I have reluctantly been compelled to omit other interesting matter ; they are 
sugar cultivation and cane farming ; railways ; electric tram service ; electric lighting of Port-of-Spain, which has rescued us from what a poet would call " cimmerean darkness;" a fine water supply and service, enabling an equally up-to-date Fire Brigade to be established, with stations in various parts of the town and country. An article on the rise and fall of San Fernando, and its rise again-as it is now showing indications of doing-an indication of increasing prosperity, such as it enjoyed in my early days, when sugar was king.

I also have had to omit some important articles on various efforts made by Venezuelan revolutionists to hatch conspiracies against the ruling powers, all of which have been attempted in this colony, including two attempts at piracy and their failure; and the murder of Felipe Ducharme, a British subject, in Venezuela by a band of five West Indians hailing from Trinidad.

These and other matters of by-gone days which would have formed interesting reading even to those who still have a vague recollection of them, have been unavoidably omitted, but if I am ever able to publish a second and cheaper edition, they and other things of equal interest will be inserted.

A great contrast of the Trinidad of Then with the Trinidad of Now will be seen by comparing the revenue of the colony in 1875 with the revenue of 1911 . In 1875 it was only $£ 341,619$; while in 1911 , it was $£ 950,743$. 
In reading over what I have written, I find that, notwithstanding the greatest care, some typographical errors have crept in ; there is one to be found at top of page 196, so notable and unwarrantable that I eannot let it pass without craving permission to correct it ; it should read :

"He was a man, take him for all in all, I shall not look upon his like again."

Others my readers will be easily able to correct but I regret that there should be any occasion to do so.

In the introductory chapter I gave a quotation from the book of Maccabees, and I will conclude with another :-

"I know that it will lie open to the censure of some. Nevertheless, I hope they are not all of one humour, and I doubt not there is a diversity of taste, so that which seemeth unsavoury to one man may seem dainty to another, and the most witless saying that is set down will seem witty to some."

"If I have done well as is fitting to the story, it is that which I desire ; but if slenderly and meanly, it is all that I could attain unto. And so I will make an end." 
ADVERTISEMENTS. 


\section{J. GLENDINNING \& CO. ESTABLISHED 1892.}

DRAPERS, HABERDASHERS, SILK MERCERS, AND

GENERAL OUTFITTERS.

BOOT AND SHOE MERCHANTS.

ALWAYS IN STOCK A MOST REPLETE ASSORTMENT OF

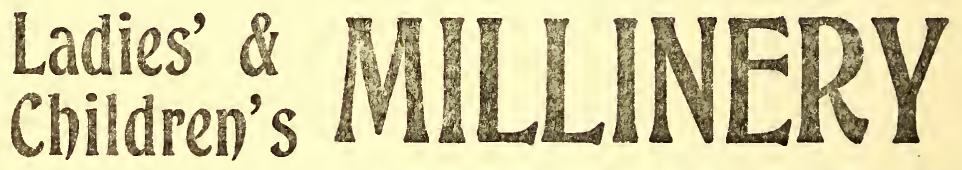

The Newest and most Ladies' Cosfumes
fashionable materials for Lalles

The latest Fashions in Men's Weap.

IN SHORT,

GLENDINNING'S

are popularly regarded as

THE FASHION SPECIALISTS.

5, FREDERICK ST. 


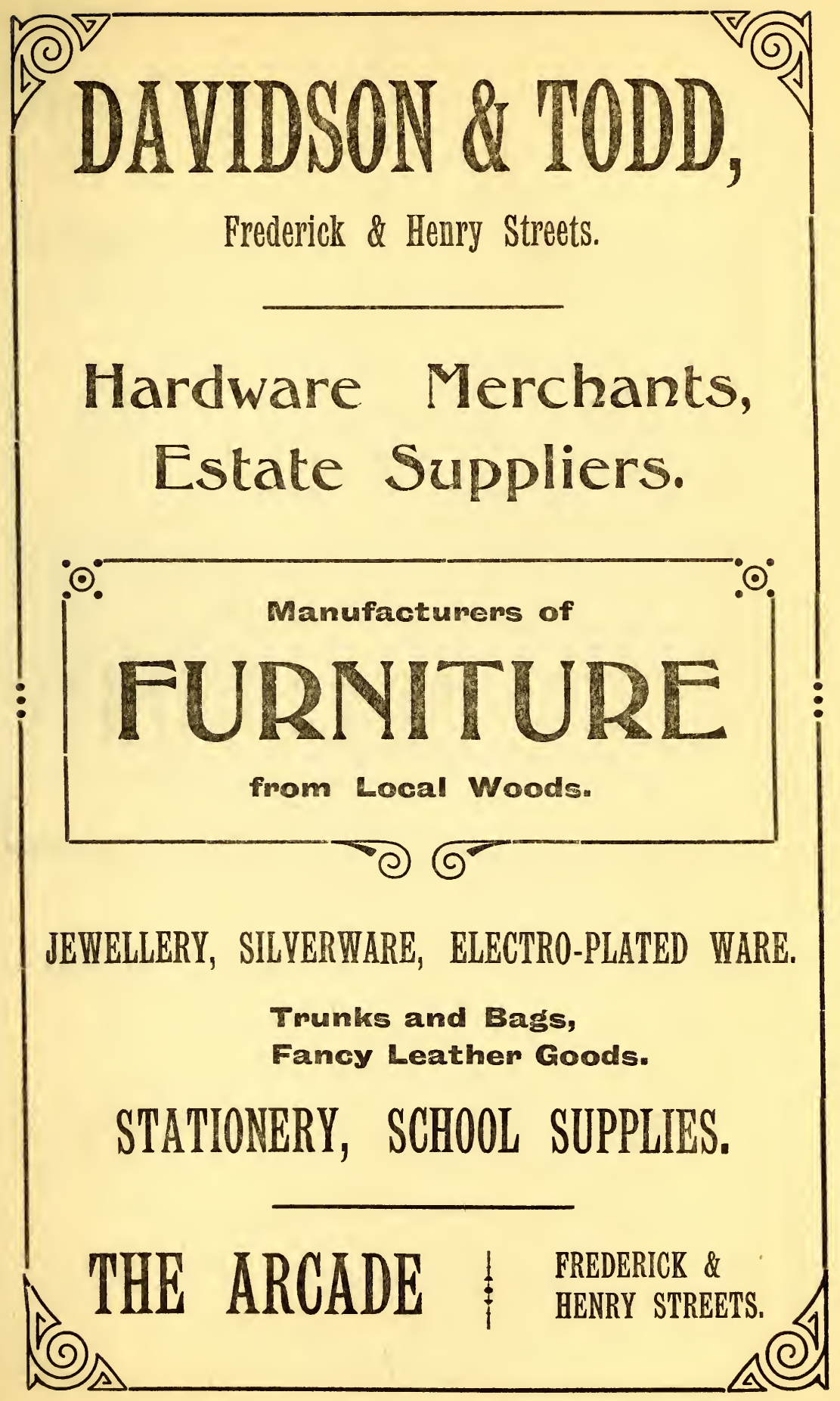




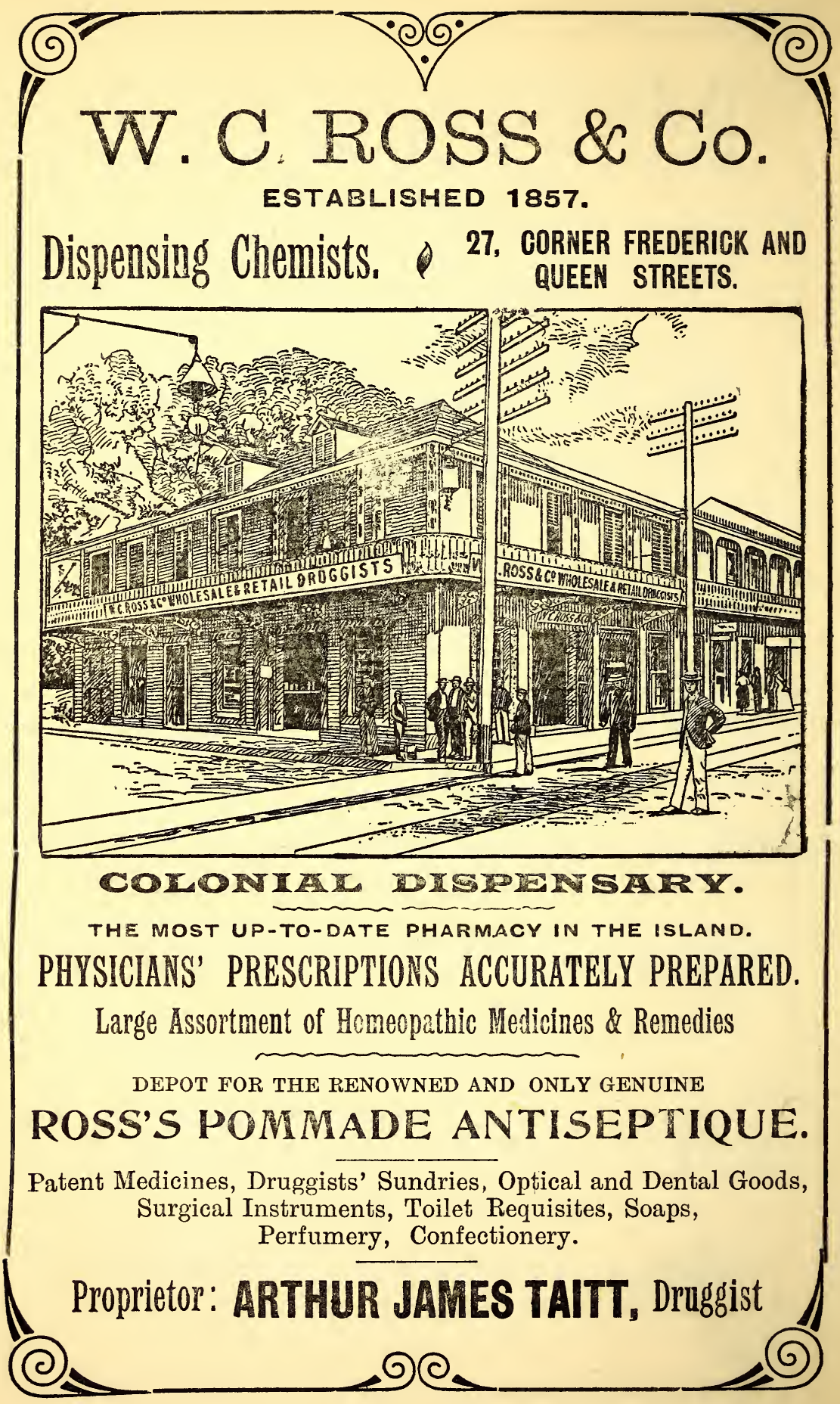




\section{TRINIDAD JEWELRY CO., LTD.}

31, Frederick Street, Port-of-Spain.

We make it our Aim to keep in Stock the Most Beautiful and Varied Assortment of - - -

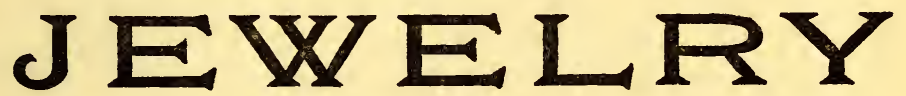

to be found anywhere.

Diamond Rings,

Engagement Rings,

Wedding Rings, \&c., \&c.
I Brooches, Trinkets,

$\times$ Bracelets, Pendants, Chains.

\section{WE ALSO STOCK A VERY FINE ASSORTMENT OF}

\section{Electro-Plated Ware suitable for} on every possible occasion.

Watches \& Clocks, $\begin{gathered}\text { all good makes } \\ \text { kept in stock. }\end{gathered}$

OUR REPAIR DEPARTMENT is in the hands of capable workmen and satisfaction is guaranteed to all who favour us with their patronage.

\section{TRINIDAD

31, Frederick Street. 


\section{ANGOSTURA BITTERS}

INVENTED IN 1824 BY DR. J. G. B. SIEGERT

\section{The Premier Bitters of the World}

formerly prepared at Angostura by Dr. Siegert and since 1875 in Port-ofSpain, Trinidad, by Dr. J. G. B. Siegert \& Sons and their Successors.

\begin{tabular}{|l|}
\hline Awarded the highest distinc- \\
tions at 25 of the principal \\
Exhibitions of the world held \\
during the last 50 years.
\end{tabular}

In 1910 the business was converted into a Limited Company styled

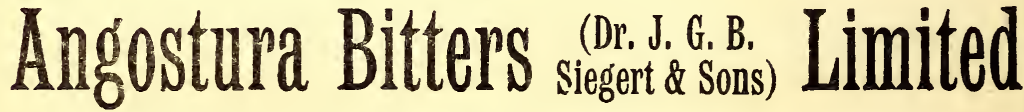

and the manufacture of the Angostura Bitters has continued under the personal charge and superintendence of Messrs. Siegert as heretofore.

\section{Factory: \\ 8, George \\ Street,}

Port-of-Spain, Trinidad, B.W.I. 


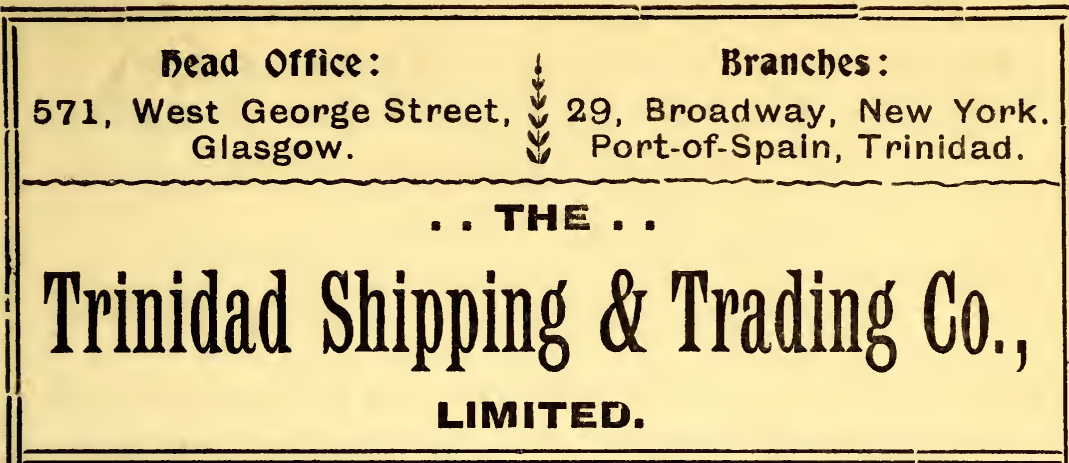

Manufacturers of ICE, LIME FOR TEMPERING, MANURIAL AND BUILDING PURPOSES.

COLD STORAGE ACCOMMODATION.

Builders, Sawmillers \& Sanitary Constructors.

\section{AGENTS FOR}

North British \& Mercantile Insurance Co., London.

Ocean Marine Insurance Co. Curtis \& Harvey, Limited, (Sporting \& Blasting Powders \& High Explosives.)

Trinidad Estates Co., Ltd. (Sugar).

Jules Merman \& Co., Bordeaux (Wines).

James Nourse, Ltd., London. Prentice Service \& Henderson, Glasgow "Direct" Line between Glasgow and the West Indies.

Compañia de Navegacion Fluvial y Costanera de Venezuela.
The Trinidad Line of Steamers

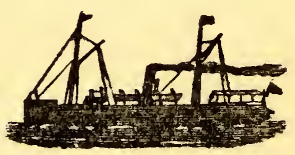

Sailing Regularly every Ten Days to and from New York, calling at the Island of Grenada both ways.

\section{Importers and General Commission Agents.}




\section{PAUL H. SCHEERER \& Co.,

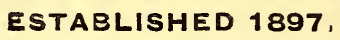

PRODUCE, SHIPPING and

GENERAL COMMISSION MERCHANTS.

\section{Agents for
HAMBURG AMERICAN LINE OF STEAMERS.}

Morris \& Co., Chicago, PORK \& BEEF PACKERS.

NORTH GERMAN INSURANCE COMPANY (MARINE) HAMBURG.

Hamburg-Bremen Fire Insurance $\mathrm{CO}_{0}$.

(INSURANCES EFFECTED AT LOWEST (URRENT RATES.)
Exponters of COCOA and CEDAR, COCOANUTS, BALATA, \&C., \&C.

IMPORTERS OF American Foodstuffs, ENGLISH, GERMAN AND FREICH PROVISIONS.

CONSIGNMENTS SOLICITED AND SOLD PROMPTLY.

Moderate Charges Guaranteed.

41. MARINE SQUARE, 41.

\section{PORT-OF-SPAIN, TRINIDAD.}




\section{Geo. R. Alston \& Co. (Established 1881).}

Port-of-Spain - - Trinidad, B.W.It

Produce, Provision, Lumber,

Shipping \& Commission Merchants

and Financial Agents.

\section{AGENTS FOR THF FOLLOWING STEAMSHIP LINES :}

East Asiatic Co., Ltd., Copenhagen. Lamport \& Bolt, Ltd., Liverpool. Seeburg Line, Mobile, U.S.A. 


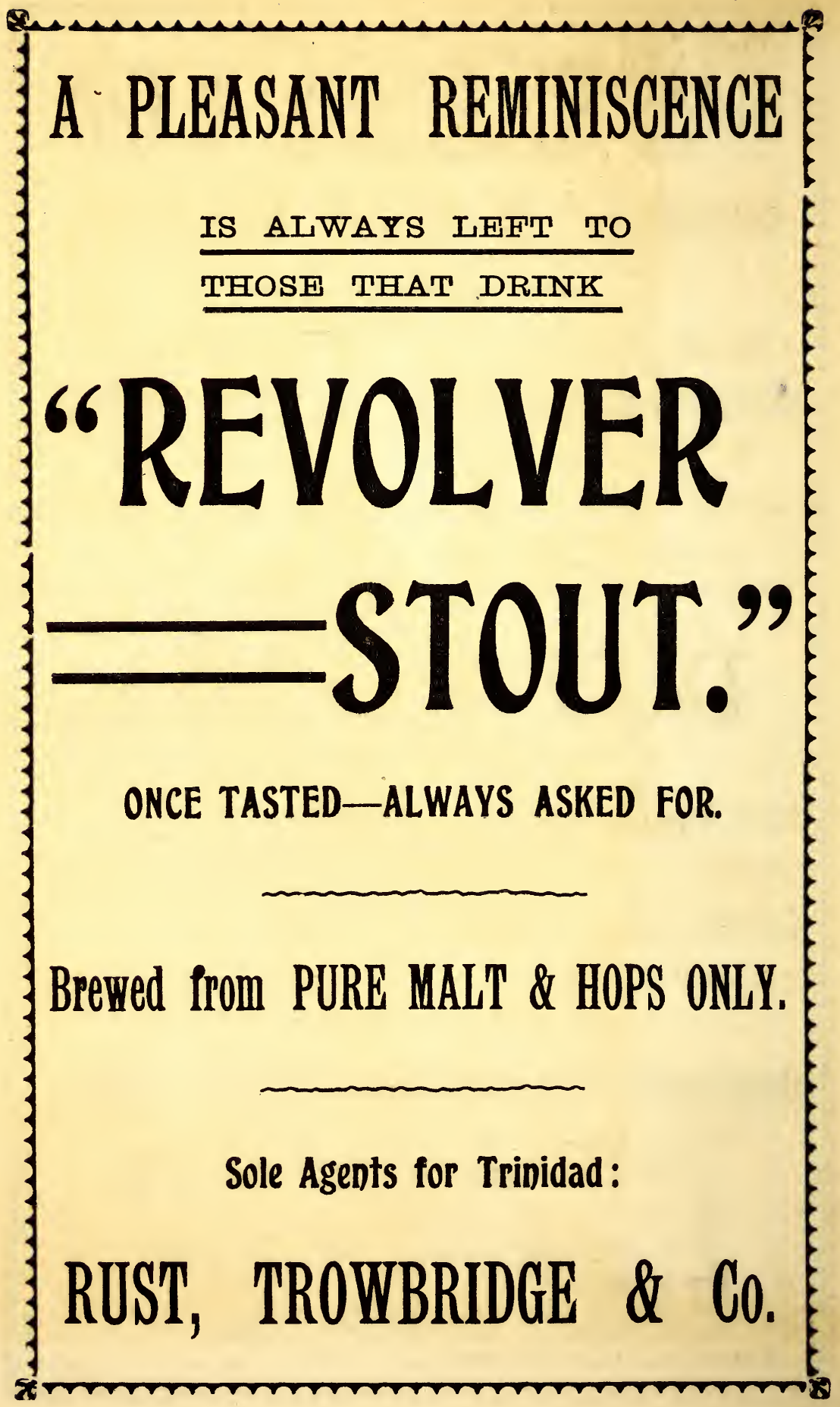


Miller's Stores, ESTABLISHED 1880 .

\section{Wholesale \& Retail Merchants.}

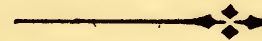

Branch Stores :

TOBAG0, ARIMA and

PRINCESTOWN.
Fead Office:

JAMES MILLER \& Co. 17, GRACECHURCH ST. LONDON, E.C.

\section{IMPORTERS OF $\ldots$}

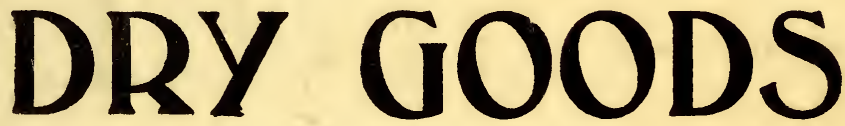

of every description.

Best English Harness and Saddlery.

English, American, Swiss \& Austrian Boots \& Shoes. Cutlery, Guns, Bedsteads \& Carpets.

SOLE AGENTS FOR

Buchanan's Famous Whiskies

"Black \& White," "Red Seal" and "Red Coat."

MAZAWATTEE TEA.

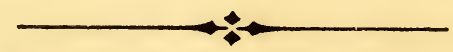

6, Frederick St. \& 15, Henry St. 
